\title{
Structural Integrity Program for the 300,000-Gallon Radioactive Liquid Waste Storage Tanks at the Idaho Nuclear Technology and Engineering Center
}

Jeffrey W. Bryant

August 2010 



\section{Structural Integrity Program for the 300,000-Gallon Radioactive Liquid Waste Storage Tanks at the Idaho Nuclear Technology and Engineering Center}

August 2010

Idaho Cleanup Project

Idaho Falls, Idaho 83415

Prepared for the

U.S. Department of Energy

Assistant Secretary for Environmental Management

Under DOE Idaho Operations Office

Contract DE-AC07-05ID14516 



\begin{abstract}
This report provides a record of the Structural Integrity Program for the 300,000-gal liquid waste storage tanks and associated equipment at the Idaho Nuclear Technology and Engineering Center, as required by U.S. Department of Energy M 435.1-1, "Radioactive Waste Management Manual." This equipment is known collectively as the Tank Farm Facility. This report is an update, and replaces the previous report by the same title issued April 2003.

The conclusion of this report is that the Tank Farm Facility tanks, vaults, and transfer systems that remain in service for storage are structurally adequate, and are expected to remain structurally adequate over the remainder of their planned service life through 2012.

Recommendations are provided for continued monitoring of the Tank Farm Facility.
\end{abstract}




\section{CONTENTS}

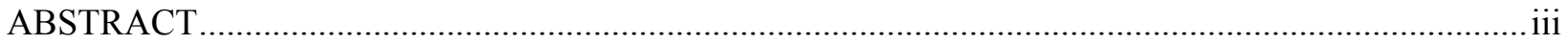

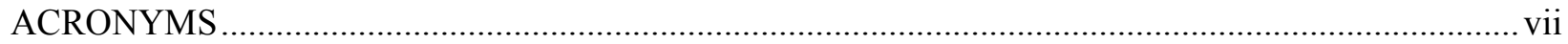

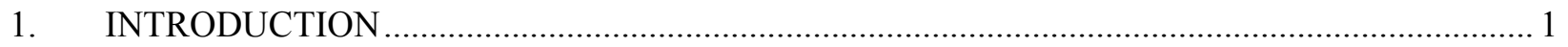

1.1 Purpose

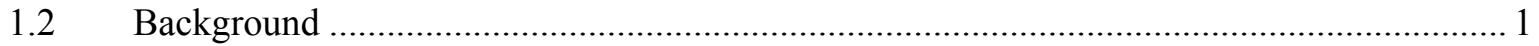

2. DESCRIPTION OF THE TANK FARM FACILITY …......................................................... 4

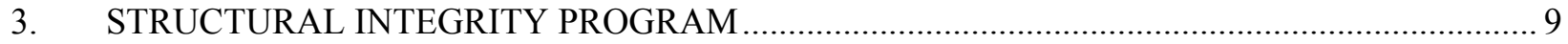

3.1 Tank Farm Facility 300,000-gal Tank Structural Integrity Program Description ................ 9

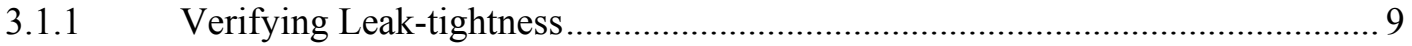

3.1.2 Identification of Degradation Modes ......................................................... 11

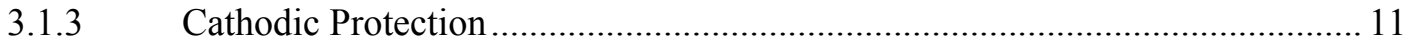

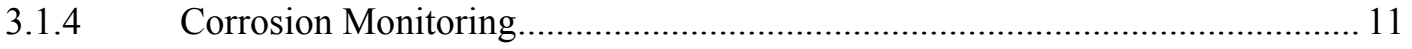

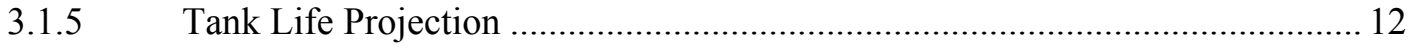

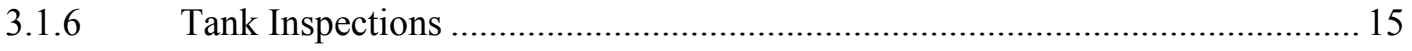

3.1.7 Adjusting and Controlling Tank Chemistry .................................................. 15

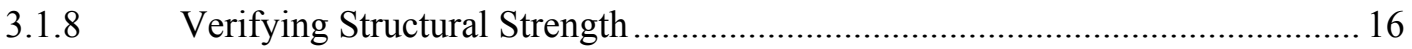

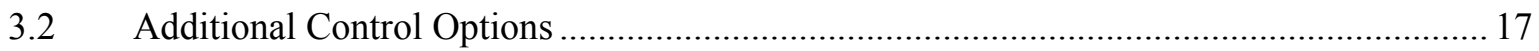

3.2.1 Potential Tank Management Methods......................................................... 17

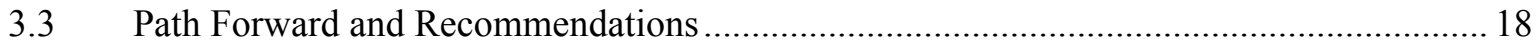

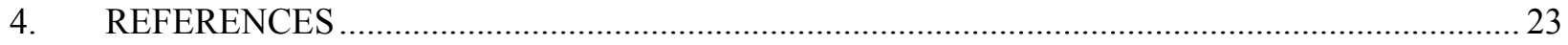

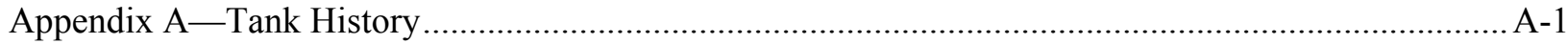

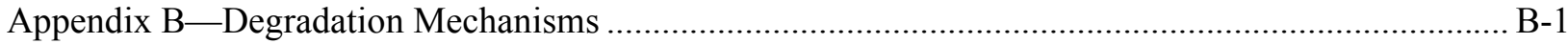

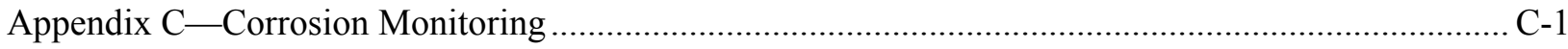

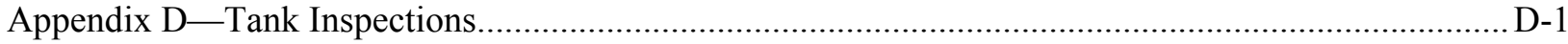

Appendix E-Laboratory-Scale Corrosion Testing .............................................................................. E-1

Appendix F-Quantification of Ancillary Equipment Degradation ......................................................

Appendix G-Quantification of Tank Vault Degradation................................................................... 


\section{FIGURES}

1. Process flow diagram for the Idaho Nuclear Technology and Engineering Center.........................2

2. Diagram of Tank Farm Facility layout (PD03-0029-01) ............................................................ 4

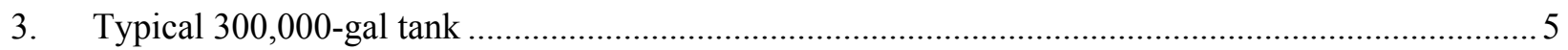

4. Octagonal, poured-in-place vault for Tank WM-180, and the type used for

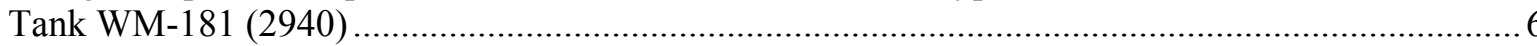

5. Octagonal, pillar-and-panel vault for Tanks WM-182 and -183, and the type used for

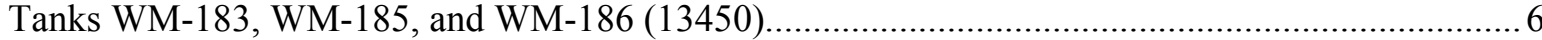

6. Square, poured-in-place vaults for Tanks WM-189 and -190, and the type used for

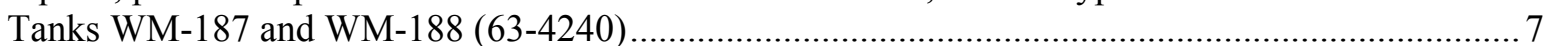

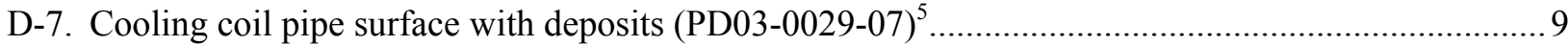

E-2. Close-up of U-bend coupons from first phase of 2001 corrosion testing (PD010403-4-22 and PD010403-4-25) ${ }^{8}$

\section{TABLES}

1. Summary of average corrosion data from various reports. 14

2. Evaluation of additional control options. 


\section{ACRONYMS}

API

CFR

DBE

DOE

ECN

EMAT

ETS

FAST

HLW

ICPP

INEEL

INTEC

LDUA

MCP

NDE

NWCF

PEW

PRD

RCRA

RP

SBW

SEM

SNF

TFF
American Petroleum Institute

Code of Federal Regulations

design basis earthquake

U.S. Department of Energy

electrochemical noise

electromagnetic-acoustic transducer

evaporator tank system

fluorinel dissolution process and fuel storage

high-level waste

Idaho Chemical Processing Plant

Idaho National Engineering and Environmental Laboratory

Idaho Nuclear Technology and Engineering Center

light-duty utility arm

management control procedure

nondestructive examination

New Waste Calcining Facility

process equipment waste

program requirements document

Resource Conservation and Recovery Act

recommended practice

sodium-bearing waste

scanning electron microscope

spent nuclear fuel

Tank Farm Facility 


\section{Structural Integrity Program for the 300,000-Gallon Radioactive Liquid Waste Storage Tanks at the Idaho Nuclear Technology and Engineering Center}

\section{INTRODUCTION}

\subsection{Purpose}

The report provides a record of the Structural Integrity Program for the Tank Farm Facility (TFF) 300,000-gal liquid waste storage tanks and associated equipment at the Idaho Nuclear Technology and Engineering Center (INTEC) at the Idaho National Engineering and Environmental Laboratory (INEEL). This equipment is known collectively as the Tank Farm Facility. U.S. Department of Energy (DOE) Order 435.1, "Radioactive Waste Management," requires all radioactive waste to be managed in accordance with the requirements in DOE M 435.1-1, "Radioactive Waste Management Manual."2 The manual states, "A structural integrity program shall be developed for each high-level waste storage tank site to verify the structural integrity and service life of each tank to meet operational requirements for storage capacity." "This document also is provided as an update to replace Status and Estimated Life of the 300,000-Gallon INTEC Tanks, ${ }^{6}$ which was issued in 1999, and Structural Integrity Program for the 300,000-gallon Radioactive Liquid Waste Storage Tanks at the Idaho Nuclear Technology and Engineering Center ${ }^{60}$, issued April 2003.

\section{$1.2 \quad$ Background}

The TFF, comprising 11 nominal 300,000-gal tanks and their associated equipment, was used to store high-level waste (HLW) and sodium-bearing waste (SBW). Seven of the tanks, WM-180, WM-181, WM-182, WM-183, WM-184, WM-185, and WM-186, have been emptied, washed, and grouted. Three of the tanks, WM-187, WM-188, and WM-189, are still being used to store SBW. In addition, Tank WM-190, the designated emergency spare tank, contains less than 600 gal of vault sump water and liquid waste resulting from past leakage through closed valves.

High-level waste is defined as the highly radioactive waste material resulting from the reprocessing of spent nuclear fuel, including liquid waste produced directly in reprocessing and any solids material derived from such liquid waste that contains fission products in sufficient concentrations; and other highly radioactive material that is determined, consistent with existing law, to require permanent isolation. ${ }^{2}$ Liquid HLW was stored in the TFF until 1998, when the last of the HLW was calcined or converted to a solid form. ${ }^{3}$ The liquid waste currently contained in the TFF is referred to as sodium-bearing waste (SBW) because of its high concentration of sodium. Sodium-bearing waste is defined as waste from second- and third-cycle fuel extraction processes, decontamination activities, and other activities incidental to fuel reprocessing. Although the TFF will no longer be used to store HLW, to ensure the safe storage of SBW and structural integrity of the TFF, the TFF Structural Integrity Program is based on the requirements applicable to HLW following the guidelines outlined in DOE G 435.1-1, "Implementation Guide for Use with DOE M 435.1-1," and the Brookhaven National Laboratory Guidelines for Development of Structural Integrity Programs for DOE High-Level Waste Storage Tanks. ${ }^{5}$ The Brookhaven guidelines specify criteria for developing programs to promote the structural integrity program directives of DOE Order 435.1. 
The structural integrity program for the Calcined Solids Storage Facilities, which are used to store HLW calcine, is being addressed in a separate document. ${ }^{7}$ Process vessels other than those in the Calcined Solids Storage Facilities are not used for storage of HLW, and are thus not included under the TFF Structural Integrity Program.

Much of the historical information following in this section was summarized from Status and Estimated Life of the 300,000-Gallon INTEC Tanks ${ }^{6}$ except as indicated otherwise. Irradiated nuclear fuel has been stored and reprocessed at the INEEL since 1953 using facilities located at INTEC (formerly the Idaho Chemical Processing Plant or ICPP). A graphical representation of the INTEC mission is shown in Figure 1. Historically, spent nuclear fuel (SNF) was brought to INTEC from a variety of reactors throughout the world and was stored either underwater in pools or in dry storage facilities for an interim period. Some of the SNF was processed to recover uranium, lanthanum, neptunium, and krypton for DOE and its predecessor organizations, the Energy Research and Development Administration and the Atomic Energy Commission. These reprocessing activities produced mixed liquid waste, which was stored in the TFF.

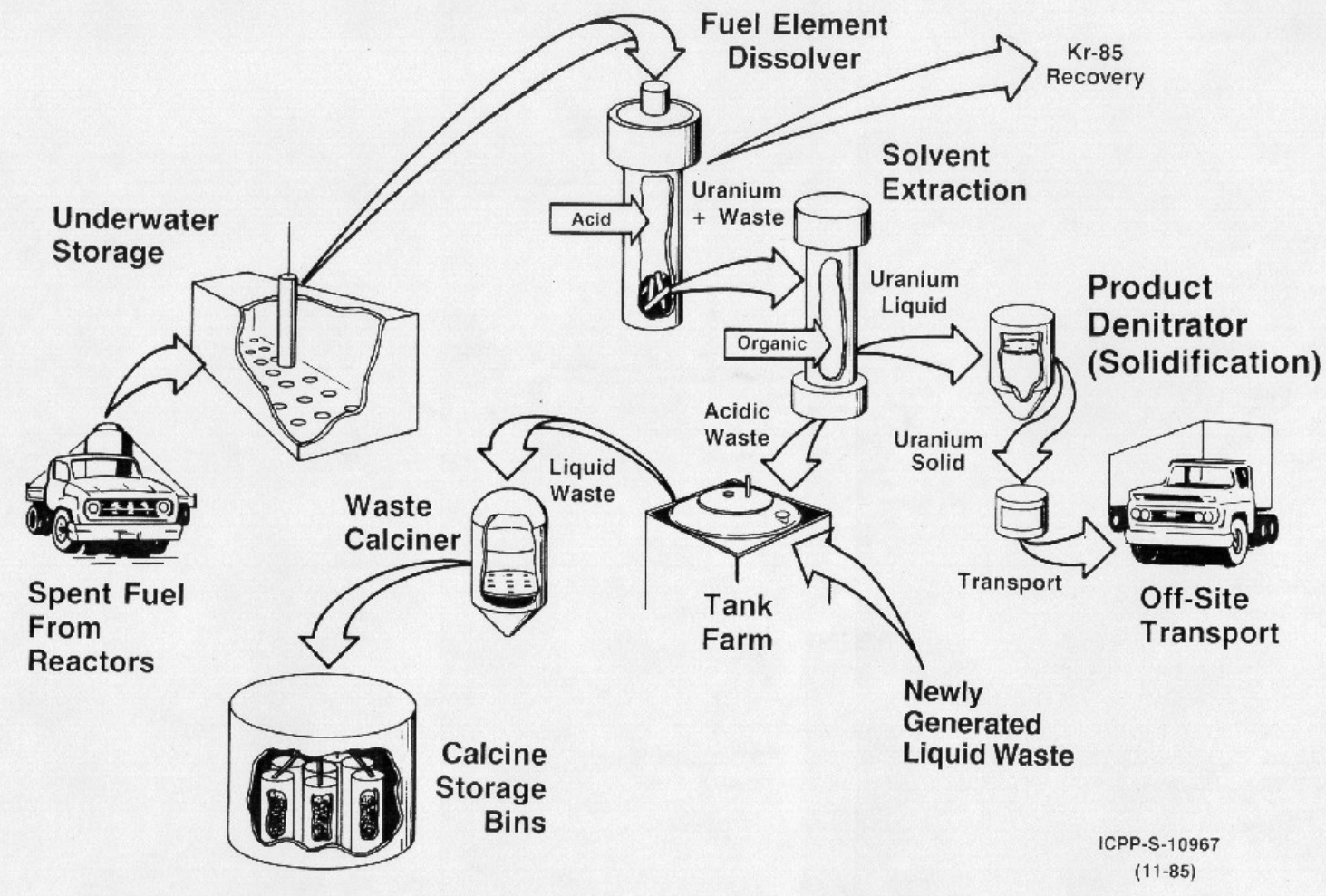

Figure 1. Process flow diagram for the Idaho Nuclear Technology and Engineering Center.

Since 1963, most of the liquid waste has been solidified using a process called calcination. Calcination evaporates the water and other volatiles from the liquid waste and converts the remaining materials to dry granular solids. The calcined solids from this process are stored in specially designed stainless steel storage bins contained in concrete vaults. These structures are referred to as Calcined Solids Storage Facilities. 
A variety of SNF types were processed at INTEC. Two types of liquid waste have been stored: HLW and SBW. The HLW was generated as a direct result of reprocessing SNF. The composition of the HLW depended on the type of fuel being processed, with aluminum and zirconium fuels producing the greatest volumes of waste. The SBW was generated from incidental activities such as second- and third-cycle raffinates ${ }^{a}$ and decontamination associated with operation of the INTEC. The term sodium-bearing waste is used to emphasize the waste's high concentration of sodium ion, which is problematic to calcination (primarily because of the potential for bed agglomeration). The high levels of sodium are a result of processing and decontamination activities making extensive use of sodium-based chemicals such as sodium hydroxide and sodium carbonate. From 1953 to 1992, SNF was routinely reprocessed, and both HLW and SBW were stored in stainless steel tanks in the TFF (usually in separate tanks). From 1963 to 1981, the waste was routinely calcined in the original Waste Calcining Facility (CPP-633), and from 1982 to 2000 the waste was calcined in the New Waste Calcining Facility (NWCF) (CPP-659). In April 1992, DOE announced that SNF would no longer be reprocessed in Idaho and called for a shutdown of the facilities at INTEC. Since that time, no more HLW has been (or is planned to be) generated from SNF reprocessing, but SBW generation continues (and will continue at a reduced rate) as a result of SNF storage, waste management, off-gas cleanup, plus decontamination and decommissioning of unused facilities. On February 20, 1998, the last of the liquid HLW that was stored in Tank WM-188 was calcined. ${ }^{3}$ Only SBW remains in the TFF because the tanks were refilled with SBW or rinsed since they were emptied of HLW. Although the TFF will no longer be used to store HLW, to ensure the safe storage of SBW, the INTEC Structural Integrity Program will follow the Brookhaven guidelines for HLW. Calcination in the NWCF and evaporation in the Evaporator Tank System (ETS, formerly known as the high level liquid waste evaporator) of SBW has reduced the total TFF volume to approximately 900,000 gal of SBW, stored in Tanks WM-187, WM-188, and WM-189. In addition, the designated emergency spare tank, WM-190, contains less than 600 gal of vault sump water and liquid waste (see Appendix A).

The U.S. Department of Energy Idaho Operations Office requested that discharges of newly generated liquid waste (NGLW) to the TFF cease by $2005 .{ }^{10}$ A milestone was established to achieve this goal by September 2005. ${ }^{11}$ This goal has been met, and as of September 30, 2005, no newly generated liquid radioactive waste may be sent to the TFF, although concentration of waste stored in the tanks may continue.

The TFF currently operates under interim status with a Resource Conservation and Recovery Act (RCRA) Part A permit, for storage of hazardous waste, and a consent order. The Notice of Noncompliance Consent Order states that cease-use of the pillar-and-panel-vaulted tanks will occur on or before June 30, 2003. ${ }^{12}$ This was accomplished as of January 9, 2002. ${ }^{13}$ Cease use of the remaining tanks will occur on or before December 31, 2012. ${ }^{14}$ The Settlement Agreement between the State of Idaho, DOE, and the Navy requires DOE to treat all high-level waste at the INEEL so that it is ready to be moved out of Idaho for disposal by a target date of $2035 .^{15}$

a. Raffinate is defined as the waste from refinement processes. At INTEC, the term raffinate was used to refer to the waste products from the refinement of waste involved in first-, second-, and third-cycle reprocessing of spent nuclear fuel. Historically, the raffinates were separated into two categories: high-level waste from first-cycle extraction and sodium-bearing waste from second- and third-cycle extraction, which were blended with other types of waste in concentrated bottoms from the Process Equipment Waste Evaporator. ${ }^{8}$ 


\section{DESCRIPTION OF THE TANK FARM FACILITY}

The INTEC TFF was constructed during the 1950s and 1960s and has been in continuous use since 1953. It consists of 11 single-shell stainless steel nominal 300,000-gal underground tanks in concrete vaults. Closure activities have been completed for some of the 300,000-gal tanks, which are identified as Tanks WM-180 through WM-186, and Tanks WM-187 through WM-190 are still in service. Figure 2 is a diagram of the TFF vessel layout. The facility is significantly different from other tank farms in the DOE complex in three respects. First, the tanks are constructed of stainless steel rather than carbon steel.

Second, the waste is stored in an acidic condition with nitric acid concentrations ranging from 1 to $3.5 \mathrm{M}$, thereby avoiding the problem of gross amounts of precipitated solids that has occurred at other locations. Third, the tanks have been repeatedly emptied and refilled over the years as the waste was processed, either by calcination or evaporation, and as additional new waste was generated from various plant activities.

The 300,000-gal tanks are similar in design to each other. Each tank is a right cylinder $15 \mathrm{~m}(50 \mathrm{ft})$ in diameter with a domed roof. The vertical sidewall is approximately $6.4 \mathrm{~m}(21 \mathrm{ft})$ high. The thickness of the stainless steel ranges from 3/16 to 5/16 in. depending on the location in the tank. Figure 3 is a schematic of a typical TFF 300,000-gal storage vessel. ${ }^{6}$ Eight of the tanks (WM-180, WM-182, WM-183, WM-185, WM-187, WM-188, WM-189, and WM-190) were built with cooling coils and were used to store heat generating HLW. The other three tanks (WM-181, WM-184, and WM-186) do not contain cooling coils and were used mainly for SBW storage.

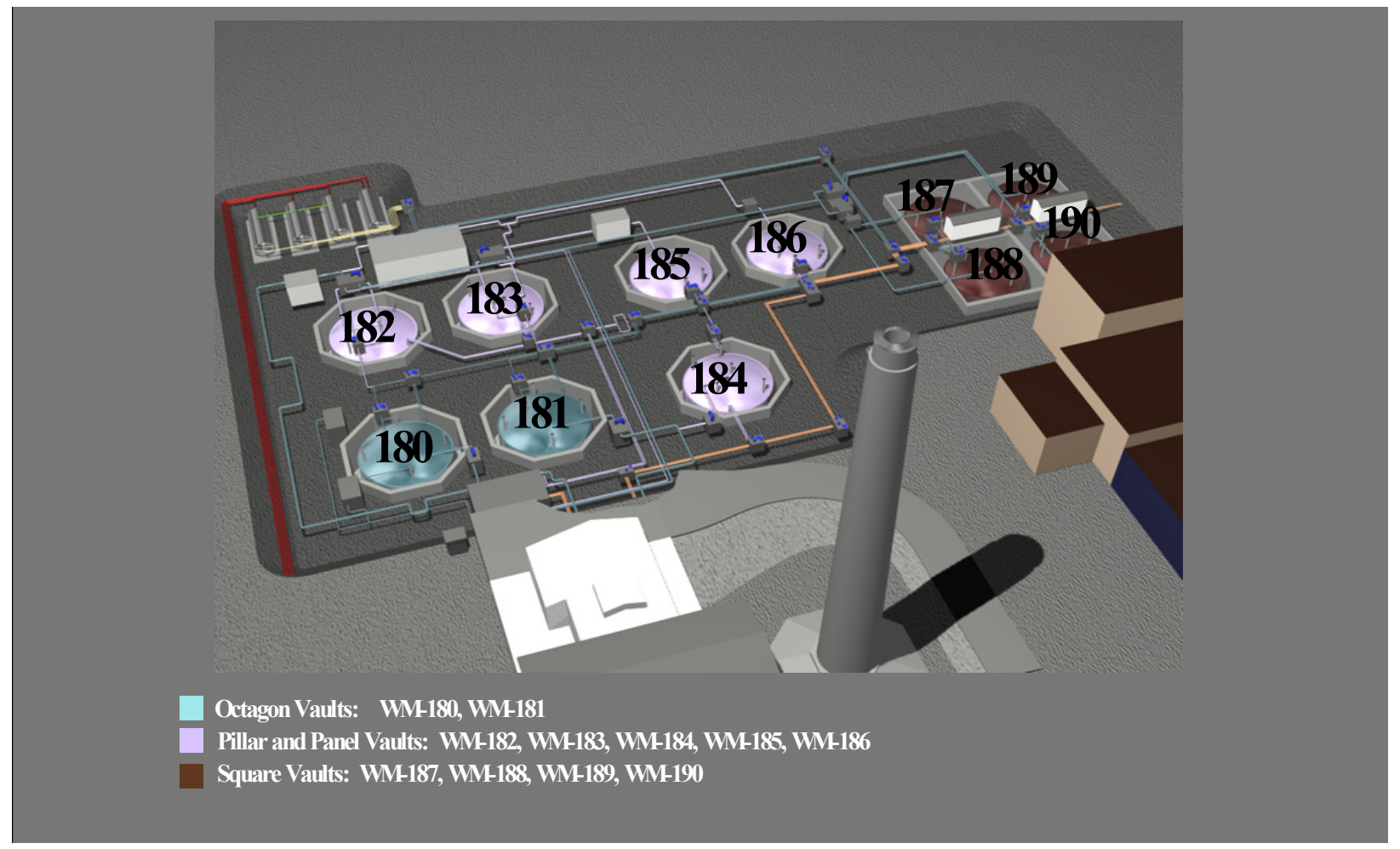

Figure 2. Diagram of Tank Farm Facility layout (PD03-0029-01). 


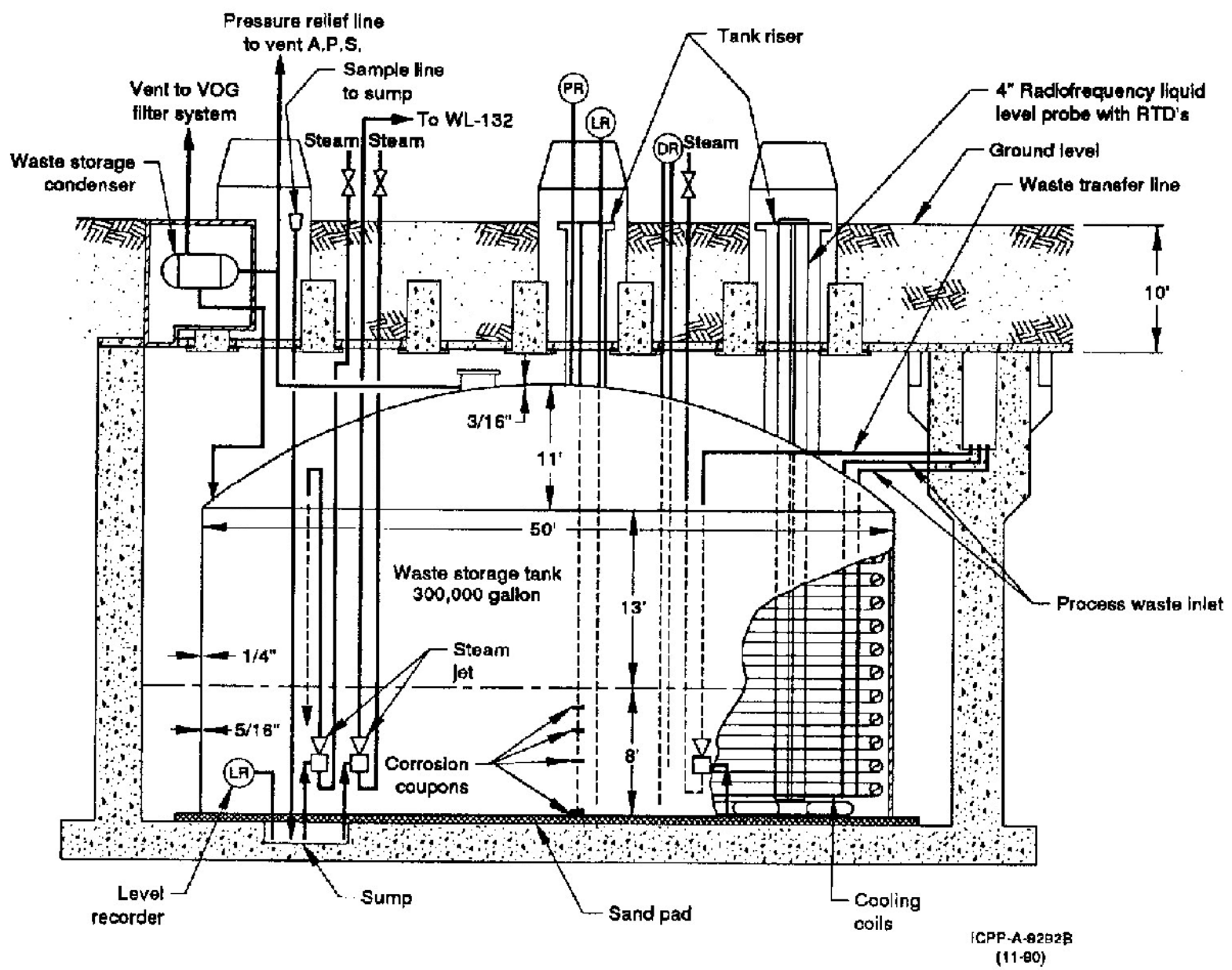

Figure 3. Typical 300,000-gal tank.

Two of the 300,000-gal tanks were fabricated out of Type 348 stainless steel (WM-180 and WM-181). The remaining nine 300,000-gal tanks (WM-182 through WM-190) were fabricated from 304L stainless steel. According to the American Iron and Steel Institute numbering system, these 300 -series stainless steels are considered austenitic stainless steels. Stainless steels are ferrous alloys that contain a minimum of $12 \%$ chromium for corrosion resistance. Austenitic stainless steels are iron and chromium alloys that have been sufficiently alloyed with nickel or manganese and nitrogen to have an austenitic structure at room temperature. ${ }^{16}$ They have been used for many years for applications requiring corrosion resistance in the nuclear, chemical, and petrochemical industries. Type 348 stainless steel is essentially the same as Type 347 stainless steel but has a restricted tantalum and cobalt content. ${ }^{17}$ Previous INEEL reports used the two types interchangeably. ${ }^{18,19}$ For consistency, elsewhere in this report the more common Type 347 stainless steel designation will be used, rather than Type 348 .

Although the 300,000-gal tanks are similar in design, the vaults that contain the tanks are very different. The first two tanks, WM-180 and WM-181, which were constructed in the early 1950s, are contained in vaults that are monolithic, reinforced concrete in an octagonal shape (see Figure 4). From 1954 to 1957 , five more tanks were constructed: WM-182, WM-183, WM-184, WM-185, and WM-186. These tanks also are contained in octagonal vaults; however, these vaults are constructed of prefabricated reinforced concrete in a pillar-and-panel design (see Figure 5). The four newest tanks, WM-187, WM-188, WM-189, and WM-190, were constructed from 1958 to 1964 and are contained in four-sectioned, reinforced square concrete vaults (see Figure 6). All of the tanks and associated vaults were designed and built to the standards at the time of construction and have served their designed function. 


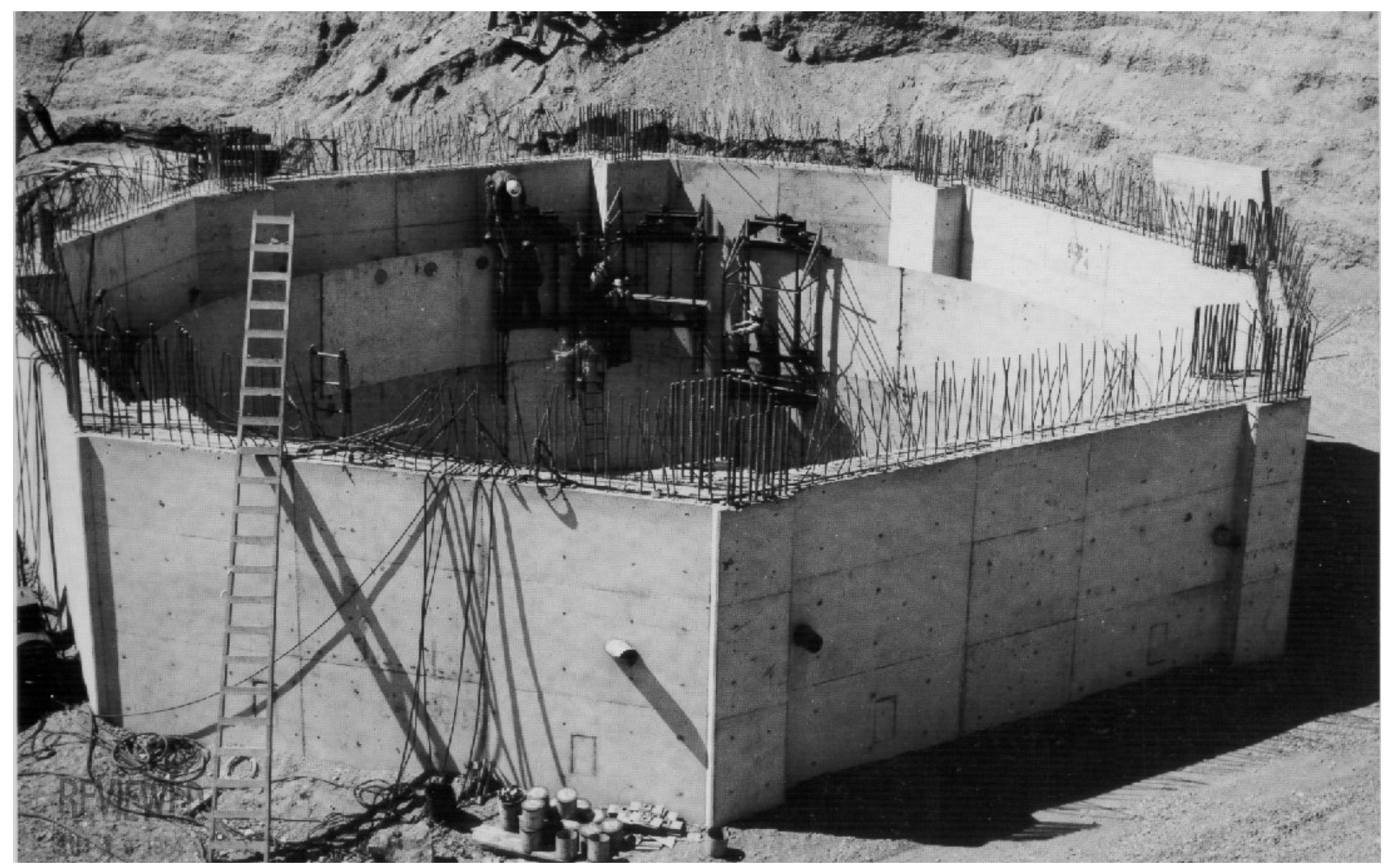

Figure 4. Octagonal, poured-in-place vault for Tank WM-180, and the type used for Tank WM-181 (2940).

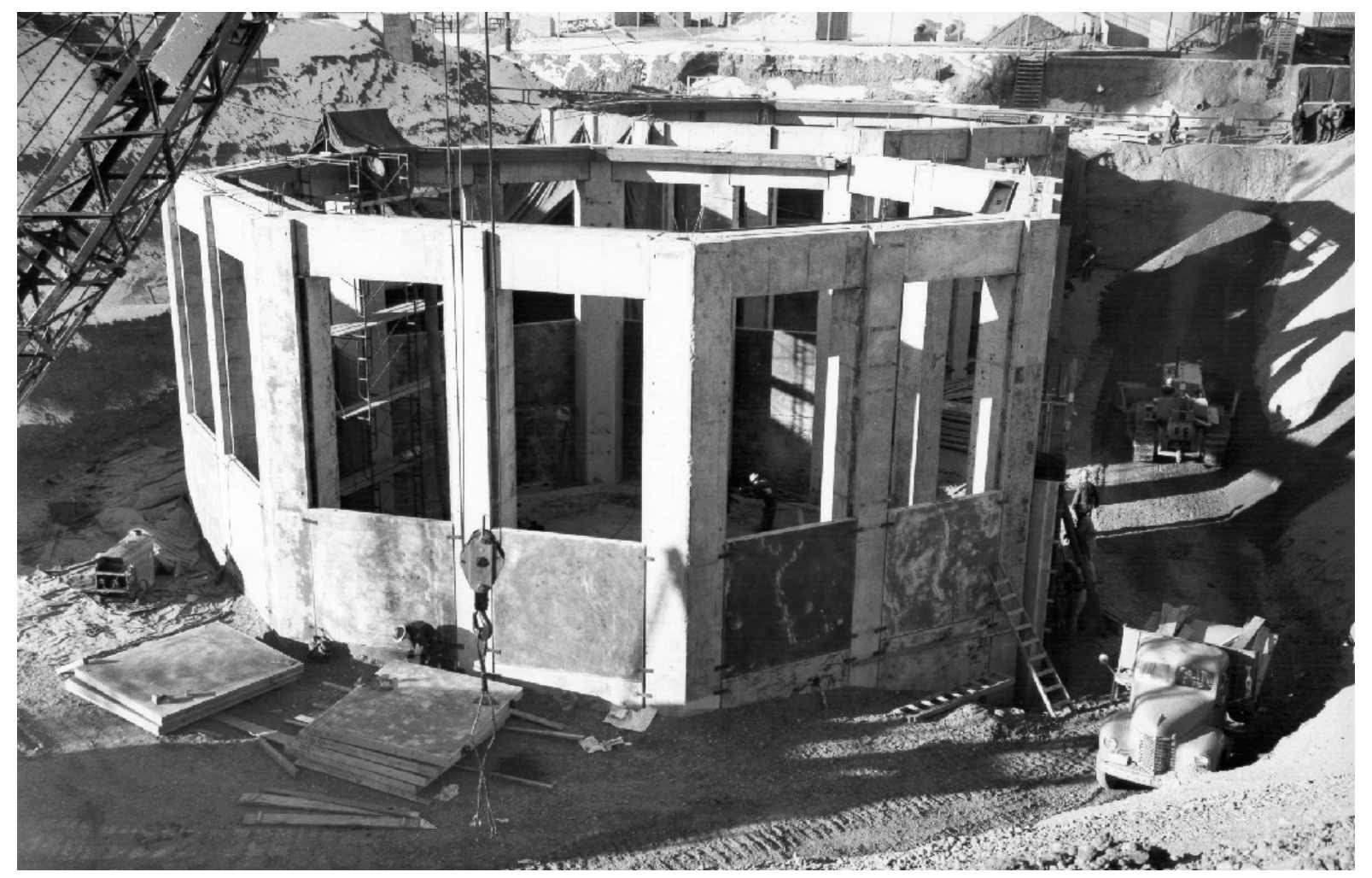

Figure 5. Octagonal, pillar-and-panel vault for Tanks WM-182 and -183, and the type used for Tanks WM-183, WM-185, and WM-186 (13450). 


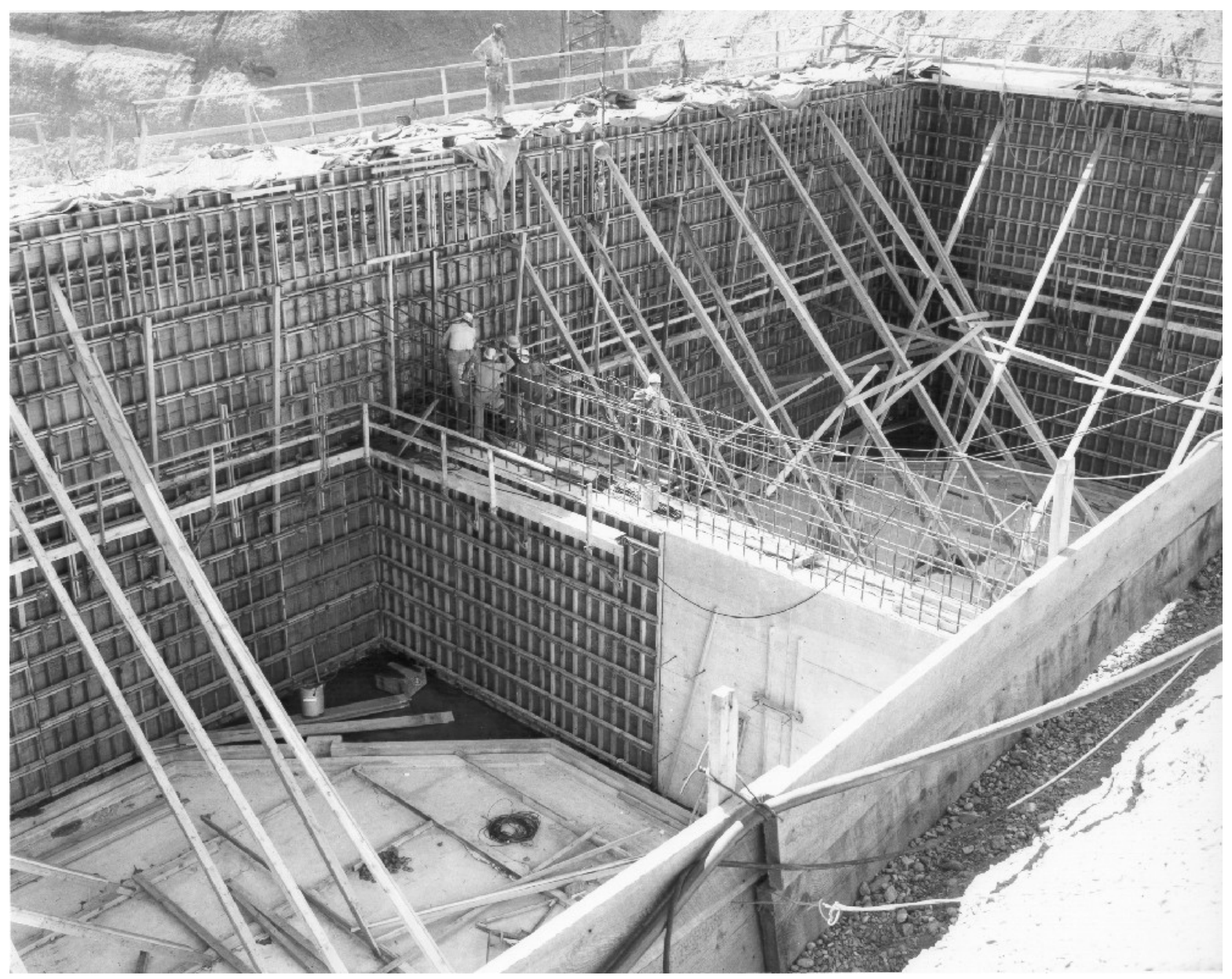

Figure 6. Square, poured-in-place vaults for Tanks WM-189 and -190, and the type used for Tanks WM-187 and WM-188 (63-4240).

The design of the vaults is important because the pillar-and-panel construction is not as robust as the monolithic construction and the unlined concrete in all of the vaults does not meet current RCRA secondary containment requirements because the acidic waste in the tanks could erode the concrete over time.

The ancillary equipment associated with the TFF includes the waste transfer systems, which consist of the transfer piping, transfer valves, and the transfer jets and airlifts necessary to transfer liquid waste into, out of, and between tanks. The ancillary equipment also includes the secondary containment and valve boxes associated with the transfer systems.

The transfer piping is fabricated of 300-series stainless steel welded pipe. The pipelines are sloped to allow drainage in the normal direction of flow into receiving tanks. The lines range in size from 2 to 4 -in. Schedule 40 pipe depending on the transfer flow rate required. Most of the transfer pipes are contained in 4 or 6-in. 300-series stainless steel pipe or in 300-series stainless steel-lined concrete troughs to provide secondary containment. Some transfer piping also is pipe-in-pipe design, and in some cases piping is embedded in concrete. The pipe encasements are sloped to allow drainage into the valve boxes, or the receiving building where leak detection equipment is installed. 
The valves used to direct the flow of transferred waste into, out of, and between the tanks are fabricated of Type 304L or 347 stainless steel and are located inside concrete valve boxes lined with 300 -series stainless steel, which provides the secondary containment. The transfer pipeline valves are operated either remotely or by reach rods from the top of the valve boxes to limit the radiation exposure to the operations personnel. The valves used in the TFF are primarily two types, high performance ball valves and bellow-sealed globe valves. Both types are designed for very low packing stem seal leak rates and are welded into the pipelines. The newer ball valves also are designed to be repaired with remote tools from the valve box lid, while the older globe valves require a physical entry into the valve box for manual hands-on repair.

If a transfer line or valve were to leak, the waste solution would flow into one of the valve box sumps where the leaked waste would be collected and radiation monitors would detect the leak. Some of the older style valve boxes had drain lines that removed any liquid leaked into the valve box sumps by allowing it to drain into one of the tank vault sumps. The valve boxes with these drain lines were required by the Notice of Noncompliance Consent $\mathrm{Order}^{12}$ to be removed from service or upgraded because the drain lines allowed leaked waste to drain into the unlined tank vault sumps. The upgraded valve boxes have had the drain lines sealed or modified so that any leaked liquid will drain into and be collected in a sump lined with 300-series stainless steel. In addition to the leak detection radiation monitor, each modified valve box has a level indicator or alarm for liquid-level detection and a steam transfer jet to remove any collected liquid. During tank closure activities grout was inadvertently introduced into several valve boxes. Cameras have been installed in these valve boxes for use in detecting leaks.

The TFF off-gas system consists of the vessel off-gas system and the pressure/vacuum relief system necessary for the transfer of waste into, out of, and between the 300,000-gal tanks.

The TFF vessel off-gas system provides a slight vacuum in the tanks so that any gases generated, air used by the monitoring instruments, and air exchanged during transfers are vented from the tanks and not allowed to build up and pressurize the tanks. The vessel off-gas consists of 4 to 12 -in. (generally Schedule 10 or 40) Type 304L or 347 stainless steel welded pipe connecting the top of each tank to the vessel off-gas filtering system located in the Waste Treatment Building (CPP-604). The vessel off-gas lines run throughout the TFF and are buried 1.8 to $3.7 \mathrm{~m}(6$ to $12 \mathrm{ft})$ below grade.

The active tanks are connected to an off-gas condenser, which was designed to remove moisture from the off-gas under high-temperature conditions for the liquid waste. Since the waste is maintained at fairly low temperatures (less than $35^{\circ} \mathrm{C}\left[95^{\circ} \mathrm{F}\right]$ in accordance with procedure), the condenser is not required or used to cool the off-gas. The condenser has been disconnected from the water supply. The condenser still acts as a drain point to drain any moisture condensed from the off-gas back into the tanks. However, the amount of liquid condensed in the off-gas lines is minimal.

The pressure/vacuum relief system in the TFF provides an alternate route to vent the tanks so that any gases generated, air used by the monitoring instruments, and air exchanged during transfers are not allowed to build up and pressurize the tank. It consists of 10 to 12 -in. Type $304 \mathrm{~L}$ or 347 stainless steel pipe connecting the top of each tank to pressure and vacuum relief valves located in relief valve pits near each tank. The pressure relief side of the valve vents the off-gases to the ventilation atmospheric protection filtering system located in CPP-649 if a pressure is generated inside the tank. The vacuum relief side of the valve allows air to be drawn into the tank if a vacuum is generated inside the tank. The pressure/vacuum relief valves can pass up to $28 \mathrm{~m}^{3}\left(1,000 \mathrm{ft}^{3}\right)$ per minute of air depending on the pressure or vacuum generated. The pressure/vacuum relief lines run throughout the TFF and are buried 2.4 to $3.7 \mathrm{~m}(8$ to $12 \mathrm{ft})$ below grade.

An operational history of the tanks is provided in Appendix A. 


\section{STRUCTURAL INTEGRITY PROGRAM}

Structural Integrity Program requirements for leak-tight tanks in service are specified in DOE M 435.1-1, Chapter II, Section Q.2.a.

A structural integrity program shall be developed for each high-level waste storage tank site to verify the structural integrity and service life of each tank to meet operational requirements for storage capacity. The program shall be capable of:

1. Verifying the current leak-tightness and structural strength of each tank in service;

2. Identifying corrosion, fatigue, and other critical degradation modes;

3. Adjusting the chemistry of tank wastes, calibrating cathodic protection systems, wherever employed, and implementing other necessary corrosion protection measures;

4. Providing credible projections as to when structural integrity of each tank can no longer be assured; and

5. Identifying the additional controls necessary to maintain an acceptable operating envelope. ${ }^{2}$

\subsection{Tank Farm Facility 300,000-gal Tank Structural Integrity Program Description}

An effective program currently is in place for the TFF to address the structural integrity program requirements of DOE M 435.1-1. A summary of the structural integrity program is provided in this section. Additional details are provided, as necessary, in the appendixes.

\subsubsection{Verifying Leak-tightness}

Two liquid monitoring systems are in place at the TFF: one for tank monitoring and one for transfer line leak detection. The tank-monitoring system instrumentation for each tank consists of three independent tank-level instruments, sump-level instruments, a pressure/vacuum instrument, a specific gravity instrument, and temperature instruments. The transfer-line leak-detection system instrumentation consists of leak-detection radiation monitors installed in each valve box and encasement sump, cameras, and level indicators or alarms installed in valve boxes and encasement sumps that do not have drain lines.

General operating procedures ${ }^{6}$ for the TFF require that before any waste can be transferred to, from, or within the TFF, instrumentation for the tanks and transfer lines involved must be in service, transfer forms must be completed, and verification must be documented that the intended transfer will not interact with other transfers. Transfers are made according to appropriate procedures in which the positioning or repositioning of valves requires the presence of at least two qualified waste processing operators or one operator and a qualified member of waste processing supervision, both of whom must agree that the correct valves are being correctly positioned.

At least one of the liquid level detection instruments for each 300,000-gal tank must be in service at all times. The sump-vault instrumentation may be relied on for no longer than 24 hours should in-tank

level instruments become inoperable. When the sump-vault instrumentation is used, it must be monitored every 2 hours to ensure that no tank leakage has occurred. When a 300,000-gal tank-level recorder range is changed, the level recorder alarm must be recalibrated. In addition, the indicated volume in the tank 
must be the same before and after the range change. If a discrepancy occurs, shift supervision must resolve the discrepancy before transfers to or from the affected tank are allowed to resume. ${ }^{6}$

The leak-detection system for the tanks consists of conventional pneumatic differential pressure instrumentation and specially designed and constructed radio-frequency probe instrumentation in the tanks, conventional differential pressure instruments in the tank vault sumps, and radiation detectors in diversion and valve box sumps. The chemistry of the TFF solutions has prevented the forming of solid crusts at the waste-vapor interface that are a problem at some facilities. As a result, the differential pressure instrumentation and radio frequency probes in the 300,000-gal tanks provide an accurate reading of tank levels. If a leak were to occur in any tank, the waste solution would flow into the concrete vault sumps, and would be reflected by a decrease in the tank-liquid level and a corresponding increase in the sump level. Detection of moisture in the vault sump alone does not indicate a tank leak, as the vault sump also collects liquid resulting from in-leakage from groundwater sources. However, the combined liquidlevel monitoring systems allow detection of leaks from the tanks of as little as 50 to $100 \mathrm{gal}^{6}$

Special radiation monitoring equipment for the tanks provides an indication of potential transfer equipment failures. Rate-meter instrumentation for the valve-box radiation levels or cameras must be operable during transfers of radioactive waste in waste transfer lines associated with the valve boxes. Rate-meter readings are taken and cameras are monitored before, during, and after each transfer. Liquid level detection instrumentation is also provided in many of the valve-boxes.

The leak-detection system for the piping system consists of radiation monitors or cameras in diversion valve boxes and selected pipe encasements. The valve box radiation monitors, which monitor the most probable leak locations, can detect leaks of less than 1 gal. ${ }^{6}$

Transfers are documented on liquid transfer sheets and other data sheets. These sheets require completion of volumetric calculations and volume limit checks. The batch transfer sheets cite the appropriate operating procedures. Plant supervision is notified when the volume transferred is greater than that received, and any discrepancy is resolved.

The TFF is operated to prevent any migration of waste or accumulated liquid out of the waste confinement systems. This is done through continuous monitoring of vault sump levels and emptying the sumps at the earliest practicable time. A spare tank is maintained for transfer of tank contents if a leak were to occur.

Operations at the TFF are administratively controlled. The capability to transfer the waste from any of the 300,000-gal tanks in case of a leak is a very important tank management option. Currently, Tank WM-190 is the designated spare should one of the other tanks begin to leak. The capacity of WM-190 is 300,000 gal. Because the waste is transferred by steam jet, the capacity of the other tanks is normally limited to 285,000 gal to allow for the extra volume that could be generated by the transfer.

In 1990, International Technology Corporation performed an interim tank assessment for the TFF in accordance with RCRA requirements 40 Code of Federal Regulations (CFR) 265.191 and 40 CFR 270.11. ${ }^{20-22}$ The assessment report states:

Because of the radioactive nature of the waste stored in the tanks, it is impractical to perform a mechanical leak check using conventional methods of pressurization. Visual inspection is also impossible. Therefore, the leak tightness requirement of the regulations had to be inferred based on available instrumentation data combined with an analysis of the sensitivity and potential errors associated with the equipment....The results of the foregoing analysis that is based on a combination of analytical methods 
and measurements indicate that the tanks do not leak at rates in excess of 0.1 gal per hour. ${ }^{20}$

The 0.1 -gal/hour value is a nonregulated value. No leaks are actually known, and the tanks were certified as leak-tight by the independent reviewer. ${ }^{20}$

Currently, no occurrence of leaks is indicated at the TFF; therefore the tanks, tank vaults, and transfer systems are presumed to be "leak-tight," according to the definition in the Brookhaven guidelines. ${ }^{5}$

\subsubsection{Identification of Degradation Modes}

Several possible aging mechanisms were identified in the Brookhaven guidelines. ${ }^{5}$ The degradation mechanisms are presented Appendix B. The following sections and Appendixes C through G provide information quantifying degradation.

The most significant modes of degradation for the TFF tanks are general corrosion, pitting and crevice corrosion, concentration cell corrosion, and stress-corrosion cracking. Aggressive chemical attack is the only significant degradation mechanism for the TFF vaults. These degradation mechanisms also apply to the transfer lines and transfer line containment systems.

\subsubsection{Cathodic Protection}

All metallic components of waste transfer and off-gas systems that contact the soil are protected from external corrosion by the cathodic protection system. The cathodic protection system consists of a system of electrical rectifiers and anodes, which applies sufficient electrical potential to the interconnected underground metallic structures to prevent oxidation and corrosion.

The cathodic protection system is maintained in accordance to procedure by the Cathodic Protection System Engineer. ${ }^{23}$ The procedure requires an annual structure-to-electrolyte (pipe-to-soil) survey and bi-monthly rectifier readings. Repair activities are initiated if discrepancies from normal values are noted. The INEEL quality assurance organization must verify the repairs. Records of all surveys and readings must be maintained until facility closure.

\subsubsection{Corrosion Monitoring}

A program to test and monitor TFF tank materials was in place from 1953 until 2003. ${ }^{18,61}$ Over time the program consisted of (1) laboratory studies to evaluate and confirm the corrosion acceptability of the fabrication materials and methods with stored liquid waste, (2) routine visual and nondestructive examinations, and (3) the use of corrosion coupons exposed to the actual liquid waste stored in the tanks. Corrosion coupons provide the most authoritative data pertaining to tank material performance. Sets of as-welded corrosion coupons of all tank construction materials (plus some other materials to provide additional data) have been placed in the waste tanks at various times at various levels.

General corrosion rates, which are useful to provide general estimates of tank wall thinning, are determined from coupon weight loss. Certain types of localized corrosion, such as pitting, stress-corrosion cracking, crevice corrosion, and preferential weld attack, are characterized by the appearance of the metal surfaces in microscopic examination and from various techniques of metallographic analysis. 
Corrosion coupons were retrieved from the tanks and analyzed in 1962, 1976, 1983, 1988, and from 1999 through $2002 .^{18,19,24-29}$ The results of these analyses are shown in Table 1, and are discussed in Appendix C. Additional corrosion coupons were removed prior to tank washing as follows:

WM-185: June 19, 2003

WM-186: July 28, 2003

WM-184: November 12, 2003

WM-181: $\quad$ March 9, 2004

WM-180: $\quad$ Approximately August 4, 2004 (the exact date was not documented).

These corrosion coupons have been cleaned and are stored on the Tank Farm, but have not been examined. Tanks WM-180 through WM-186 have been washed and grouted, and no longer have corrosion coupons in them.

Minor localized pitting was identified on some of the corrosion coupons retrieved and examined during 1999 through 2002 from Tanks WM-182, WM-183, WM-187, WM-188, and WM-189. ${ }^{24-27}$ To evaluate the impact of this pitting, a fitness-for-service evaluation was performed, as discussed in the next section.

Based on the schedule to empty the tanks in 2010 - 2012, the fitness-for-service evaluation, and laboratory studies performed in 2003, CWI management has decided that the corrosion coupons in the remaining tanks (WM-187, 188, and 189) will not be pulled until the tanks are emptied.

\subsubsection{Tank Life Projection}

The most unfavorable effect of degradation would be leakage of the contents of a tank to the outside environment. If this were to occur, the tank could either be repaired or taken out of service. However, because of the highly radioactive nature of TFF solutions, the radiation exposure associated with repairing tanks probably would be unacceptable. Therefore, the preferred option is to maintain the tanks in a fit for service condition for their operating life. The effects of degradation can be quantified by estimating the service life of a tank.

The American Society of Mechanical Engineers and American Petroleum Institute (API) design codes and standards for pressurized equipment provide rules for the design, fabrication, inspection, and testing of new pressure vessels, piping systems, and storage tanks. These codes do not address degradation of equipment while it is in service or deficiencies caused by degradation or the original fabrication that may be found during subsequent inspections. Fitness-for-service assessments are quantitative engineering evaluations that are performed to demonstrate the structural integrity of an in-service component containing a flaw or damage. Guidance for conducting fitness-for-service assessments is provided in API Recommended Practice (RP) 579, "Fitness-for-Service."30

A fitness-for-service assessment for the tanks that will remain in service over the next decade was conducted by CC Technologies in 2002. ${ }^{31}$ An engineering, research, and testing firm, CC Technologies specializes in corrosion control, fitness-for-service, pipeline and plant integrity analysis, corrosion monitoring, materials evaluation and selection, and the design and development of instrumentation and software. The fitness-for-service and remaining life of Tanks WM-187, WM-188, and WM-189, which continue to be used for storing SBW, were assessed using the accepted industry practice methods of API RP 579. 
Based on the worst pit observed on the coupons, fitness for service and the remaining life of the tanks were evaluated by Level 1 and Level 2 methods of API RP 579. Level 1 methods are the most conservative, with the analysis accuracy increasing and the degree of conservatism decreasing from Level 1 to Level 3. Both the Level 1 and 2 analyses indicated that the tanks are fit for continued service even if they contain the worst amount of pitting observed in the corrosion coupons at the location of highest stress. For Level 1 analysis, the minimum remaining life was computed to be 48 years. For Level 2 analysis, the minimum remaining life was computed to be 90 years. ${ }^{31} \mathrm{CC}$ Technologies also recommended increasing the frequency of corrosion coupon examinations to approximately once every 5 years, along with use of electrochemical noise monitoring. ${ }^{31}$ These recommendations are evaluated in Table 2 .

Based on the schedule to empty the tanks in 2010 - 2012, the fitness-for-service evaluation, and laboratory studies performed in 2003, CWI management has decided that the corrosion coupons in the remaining tanks (WM-187, -188, and -189) will not be pulled until the tanks are emptied. 
Table 1. Summary of average corrosion data from various reports.

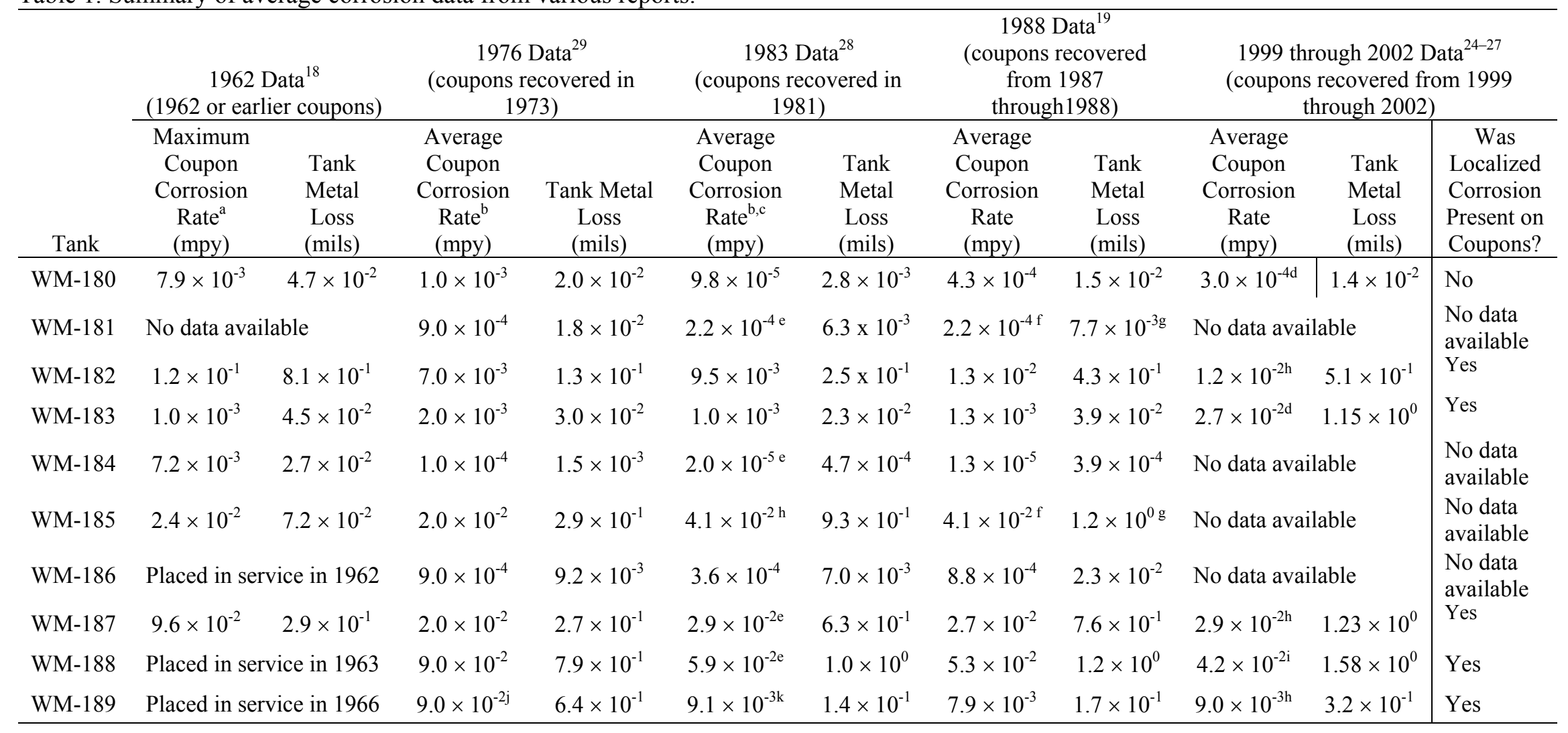

a. No average data are available.

b. The values shown are based on coupons at the 45 -cm (18-in.) level unless otherwise noted.

c. New coupons were placed in service June 1978.

d. The value shown is based on coupons located at the tank bottom.

e. The value shown is based on coupons at the $91-\mathrm{cm}(36-$ in.) level.

f. The value shown is from 1983 data. $^{19}$

g. The value shown is based on 1983 corrosion rate and 1988 service time.

h. The value shown is based on coupons at the $183-\mathrm{cm}$ (72-in.) level.

i. The value shown is based on coupons at the $122-\mathrm{cm}(48$-in.) level.

j. The corrosion estimate is based on data from Tank WM-188.

$\mathrm{k}$. The value shown is from welded coupons.

Note: Each tank has a 50-mil (0.050-in.) corrosion allowance.

mpy $=$ mils per year 


\subsubsection{Tank Inspections}

Video inspections inside Tanks WM-182, WM-183, WM-187, and WM-188 were done to test equipment and support tank closure activities (see Appendix D). ${ }^{32,33}$ Video inspections were completed of Tanks WM-182 and WM-183 as part of preliminary cleaning and sampling of the tanks to support RCRA closure. Although the video inspections do not provide quantitative information about the tanks, they allow for identification of larger problems. Based on the video inspections, the tanks appear in very good condition. ${ }^{74}$ A small layer of solids was observed on the floor of most of the tanks that were inspected; therefore, the condition of most of the tank floors was not directly observed. Cleaning activities in Tanks WM-182 and WM-183 have removed most of the solids in those tanks. The WM-182 and WM-183 tank bottoms appear to be in excellent condition.

Tanks WM-185, WM-186, WM-184, WM-181, and WM-180 also received video inspections as part of tank washing. Solids in these tanks were confirmed to be less than one inch deep, and no obvious corrosion problems were observed. Tanks were washed as follows ${ }^{62}$ :

WM-182: $\quad$ June 2002 - September 2002

WM-183: $\quad$ October 2002 - February 2003

WM-185: $\quad$ September 2003 - October 2003

WM-186: $\quad$ October 2003 - November 2003

WM-184: $\quad$ November 2003 - December 2003

WM-181: $\quad$ April 2004 - May 2004

WM-180: $\quad$ November 2004 - January 2005.

Because of very limited accessibility, no detailed visual inspections of the vaults have been performed since the tanks were placed into radioactive service. However, during sampling of the vault sump of Tank WM-182 in 2001, solid material of varying sizes was observed to be resting on top of the wire-mesh basket over the vault sump. ${ }^{52}$ Most of the solids appear to be approximately $1.3 \mathrm{~cm}(0.5 \mathrm{in}$.) across or smaller. The source of these solids was not determined. The Tank WM-190 vault was entered in late 1973, 9 years after construction was completed, to inspect for water sources into the vault. Water was entering through tank riser structures and through the roof beam-to-wall joints. No evidence was observed of water having entered through the vertical walls or through the wall-to-base slab joint. ${ }^{36}$ Camera inspections of the vault sumps for tanks WM-184 and WM-185 were also performed. The WM-184 sump looked muddy, and the jet for the WM-185 sump was off to the side of the sump. As with WM-182, solids apparently from concrete spalling were visible.

\subsubsection{Adjusting and Controlling Tank Chemistry}

During the six decades of TFF operation, a wide variety of nuclear fuel types have been received and processed. Each type of fuel reprocessed has required a unique chemical dissolution and separations flow sheet and operating conditions for effective chemical separation of the uranium from the waste products. Whenever a new process was developed, laboratory tests were conducted in advance to confirm the corrosive acceptability of the anticipated new waste solution. Additional laboratory tests were conducted to obtain information on the performance of the same materials in chemical solutions that were to be used later to decontaminate various facilities. During the actual fuel processing campaigns, the chemical compositions of the waste solutions were monitored to maintain process control. When necessary, the compositions were chemically adjusted to ensure that they met the appropriate 
specifications before waste was transferred to the TFF. ${ }^{37}$ Considerable attention also was given to making certain that incompatible chemical waste was not combined in the same storage tanks. ${ }^{37}$

Laboratory studies continued to be performed through FY 2003 to ensure acceptable storage conditions within the TFF. As of September 30, 2005, no newly generated waste will be added to the TFF, and completed laboratory studies bound current storage conditions, so no further laboratory studies are planned. Information on recent studies is included in Appendix E.

The chemical parameters of the TFF are tracked for a variety of reasons including (1) calcine characterization, (2) experimental tests to determine waste blending requirements, (3) Environmental Impact Statement development, ${ }^{38}(4)$ in case of leaks for RCRA reporting, and (5) corrosion control. Tank chemistry is tracked using tank sample analyses, analysis of input streams, and estimated chemistry of some input streams. The tanks are sampled at the NWCF. Volume reduction causes the concentration of corrosive components in the waste to increase. The bottoms generated from operation of the ETS contain about 3- $M$ acid, about $6.5-M$ nitrate, about 1,000 to 1,200-ppm chloride, up to 700-ppm fluoride, and various other constituents including mercury. The impact of this chemical composition on the tanks has been studied, as discussed in Appendix E.

Procedures require waste streams going to the process equipment waste system or the TFF to meet limits specified in PRD-166, "INTEC PEW and Tank Farm Chemical Acceptance Criteria." ${ }^{40}$ The limits include a specification that for corrosion enhancing chemicals the $\mathrm{pH}$ must be kept at less than 4 except under special circumstances. ${ }^{40}$

Cooling coils were available in eight of the 11 TFF tanks. The SBW currently stored in the tanks is much less radioactive than the raffinates that previously were stored in them, and the decay heat produced is low enough that the cooling coils are no longer needed to keep solutions below $35^{\circ} \mathrm{C}\left(95^{\circ} \mathrm{F}\right)$, which is the current temperature limit.

\subsubsection{Verifying Structural Strength}

During the late 1980 s and early 1990 s, various seismic studies were performed on the TFF. ${ }^{41-48}$ Conclusions of all of the studies were that the tanks meet design basis earthquake (DBE) criteria. The cast-in-place octagonal vaults used for Tanks WM-180 and WM-181 meet DBE seismic criteria, and the square vaults used for Tanks WM-187, WM-188, WM-189, and WM-190 probably could be shown to meet the DBE criteria if a definitive analysis were done. The pillar-and-panel tank vaults used for Tanks WM-182, WM-183, WM-184, WM-185, and WM-186 probably could not be shown to meet the DBE criteria, but even so, they would not be expected to fail catastrophically (to collapse) during a DBE. ${ }^{64}$ A DBE would result in some damage to the pillar-and-panel vaults such as flexural cracks in the panels. However, the vaults are expected to maintain a barrier against the surrounding soil and prevent it from intruding into the vault. The conclusion of all of the seismic analyses is that none of the tanks is expected to leak as a result of a DBE.

Based on this information, the cast-in-place octagonal vaults and the square vaults are considered to be structurally adequate, according to the definition given in the Brookhaven guidelines. ${ }^{5}$

The tanks and vaults for WM-180 through WM-186 have now been grouted.

The tanks that remain in service for SBW storage, WM-187, WM-188, WM-189, and WM-190, and their associated vaults and transfer systems, are considered to be structurally adequate, and are expected to remain structurally adequate over the remainder of their planned service life through $2012 .{ }^{41-}$ 48

Cease-use of the pillar-and-panel vaulted tanks was accomplished on January $9,2002 .{ }^{13}$ 
Based on results of the tank-life assessment and seismic analyses, the 300,000-gal tanks are considered to be structurally adequate.

\subsection{Additional Control Options}

Verification of leak-tightness and structural adequacy and integrity was successfully demonstrated above. Although an effective structural integrity program is currently in place, management options exist for continued operations and monitoring of the tanks. The management options addressed in the Brookhaven guidelines ${ }^{5}$ encompass continued monitoring, improved corrosion monitoring, cathodic protection, chemistry control, temperature control, electrochemical techniques, nondestructive examinations, retrieval of waste, repair, and new barriers or tanks. Several of these management options are currently being implemented as described above, and others have been considered, as discussed below.

A number of actions related to either repair or cease use of TFF-related equipment are identified in the Notice of Noncompliance. ${ }^{12}$ In general, the management approach that is being taken is to limit repair work in the TFF to only that necessary to achieve the goal of continued safe operation and closure of the | TFF by 2012. Large-scale repairs to bring tank vaults into compliance with RCRA secondary containment requirements are not feasible because of the radiation levels in the TFF. However, numerous upgrades to valves and valve box containment systems have been made, ${ }^{50}$ and continued to be made through FY2006.

\subsubsection{Potential Tank Management Methods}

Although an effective structural integrity program is in place and tank structural integrity has been established (see Section 3.1), the Brookhaven guidelines ${ }^{5}$ suggest nondestructive examinations, based on accessibility, as listed below.

- $\quad$ Periodic visual examination of tank interiors

- $\quad$ Video and ultrasonic inspection of tank vaults, and tank exteriors

- Nondestructive examination of tank interiors.

These examinations are addressed in the evaluation in Section 3.3.

Additional activities that have been evaluated as a result of the TFF Structural Integrity Program include the following:

- $\quad$ Corrosion monitoring

- $\quad$ Installation of replacement corrosion coupons in Tank WM-187

- Installation of types of improved corrosion coupons such as a floating coupon rack, which could provide information on vapor-liquid interface corrosion

- Increased frequency of corrosion coupon evaluations

- Development and installation of an electrochemical noise probe system to provide the possibility of real-time indications of pit development.

- $\quad$ Other

- Increased tank chemistry controls

- $\quad$ Development and deployment of the light-duty utility arm (LDUA) nondestructive examination (NDE) end effector. 


\subsection{Path Forward and Recommendations}

Factors such as operating assumptions, schedule, and the condition of the tanks must be considered in evaluation of the path forward and recommendations for the TFF. These factors are summarized below.

- $\quad$ The TFF has been emptied of HLW and in the future will store only SBW.

- Currently, only three tanks contain SBW. The others have been emptied and grouted.

- Corrosion coupon evaluations to date have identified only slight localized corrosion, while DOE M 435.1-1 allows controlled use of tanks with leaks. ${ }^{2}$

- Interior video inspections indicate that the tanks are in good condition. ${ }^{34}$

- The tank life assessment in 2002 computed the minimum remaining life of the tanks to be 48 years, based on corrosion allowances and corrosion coupon evaluations. ${ }^{31}$

- The tanks are near the end of their planned life. Closure of the remaining tanks by 2012 is

| identified in the CWI Baseline Schedule. ${ }^{11}$ The goal is to shut down the TFF as quickly as possible without compromising protection of the public and the environment.

- $\quad$ The TFF Structural Integrity Program has been shown to be effective, and meets the intent of structural integrity program requirements in DOE M 435.1-1.2

Along with considering cost and benefit, the options for potential management of the TFF were reviewed against these factors, and a decision was then made about which ones to pursue. Table 2 shows the results of this evaluation.

Updated tank information will be reported periodically as a result of TFF Structural Integrity Program activities. 
Table 2. Evaluation of additional control options.

\begin{tabular}{|c|c|}
\hline Management Option & Status Summary, Comments and Path Forward Recommendations \\
\hline $\begin{array}{l}\text { Video and ultrasonic inspection } \\
\text { of tank vaults and tank exteriors }\end{array}$ & $\begin{array}{l}\text { Status-Video and ultrasonic inspection of the tank vaults and exteriors has not been completed. } \\
\text { Comments-As of } 2003 \text {, the Hanford Site and Savannah River Site were performing baseline exterior NDE scans of } \\
\text { their tanks, to be followed by subsequent comparative scans on a } 5 \text {-year schedule based on plans to use their tanks for } \\
\text { many more years. Magnetic wall crawlers were being used to perform the scans. The equipment used at Hanford and } \\
\text { the Savannah River Site will not work on the TFF tanks because they are constructed of stainless steel as opposed to } \\
\text { the carbon steel at Hanford and Savannah. No equipment is currently available to perform exterior NDE of the TFF } \\
\text { tanks. }{ }^{51} \\
\text { Accessibility into the tank vaults is very limited for the tanks that continue to store SBW. Remote installation of a } \\
\text { video camera could be done only after piping is cut out and removed from the two vault sump access risers. However, } \\
\text { the piping is required for emptying the sumps in case of a leak. The two vault sump access risers are about } 45 \mathrm{~cm} \\
\text { (18 in.) from the tank wall; therefore, video inspections, if performed, would only allow two small arcs of the tanks, } \\
\text { which are } 15-\mathrm{m} \text { ( } 50 \text {-ft) in diameter, to be inspected. Video inspection of a portion of the square vaults might be } \\
\text { possible though, if a small pan/tilt/zoom camera with lighting system were used. Although the Tank WM-187 } \\
\text { concrete vault has been exposed to tank solution as a result of tank siphoning, }{ }^{52} \text { laboratory studies show that } \\
\text { penetration of the concrete would have been less than } 0.5 \text { cm ( }(0.2 \text { in.); therefore, the vault is expected to be in good } \\
\text { shape }{ }^{53-56} \\
\text { Interior inspections of TFF tanks have been performed, and no problems were detected at the resolution of the video } \\
\text { systems used. The tank exterior conditions have been less severe than that of the interior of the tanks. } \\
\text { Recommendation-Do not pursue video and ultrasonic inspection of the tank vaults and tank exteriors. }\end{array}$ \\
\hline $\begin{array}{l}\text { NDE inspection of the tank } \\
\text { interiors. }\end{array}$ & $\begin{array}{l}\text { Status-No NDE of the tank interiors has been done. Comments-The stainless steel tank construction limits the } \\
\text { number of available methods to perform NDE of the tanks. Most of the NDE systems currently in use at DOE sites } \\
\text { consist of magnetic wall crawlers, which cannot be used. One possible method for inspecting the tank bottom to detect } \\
\text { pitting or thinning of } 20 \% \text { of the wall thickness or greater is an electromagnetic-acoustic transducer (EMAT) system, } \\
\text { which was being developed by the Center for Nondestructive Evaluation at Iowa State University as of } 2003 \text {. } \\
\text { However, further development and testing of the EMAT was required. } \\
\text { An NDE end effector was designed for the LDUA, but there were many unknowns concerning the potential } \\
\text { effectiveness of this system. For example, whether the LDUA NDE end effector could be modified to operate in } \\
\text { acidic SBW solution is questionable. With the design, the only tanks in which the LDUA NDE end effector could be } \\
\text { used were already empty and were not planned to be used again; therefore, the information obtained from such } \\
\text { inspections would be of limited benefit. The existing leak monitoring program provides adequate indication of leaks. } \\
\text { Recommendation-Do not pursue NDE of the tank interiors or development and deployment of the LDUA end } \\
\text { effector. }\end{array}$ \\
\hline
\end{tabular}


Table 2. (continued).

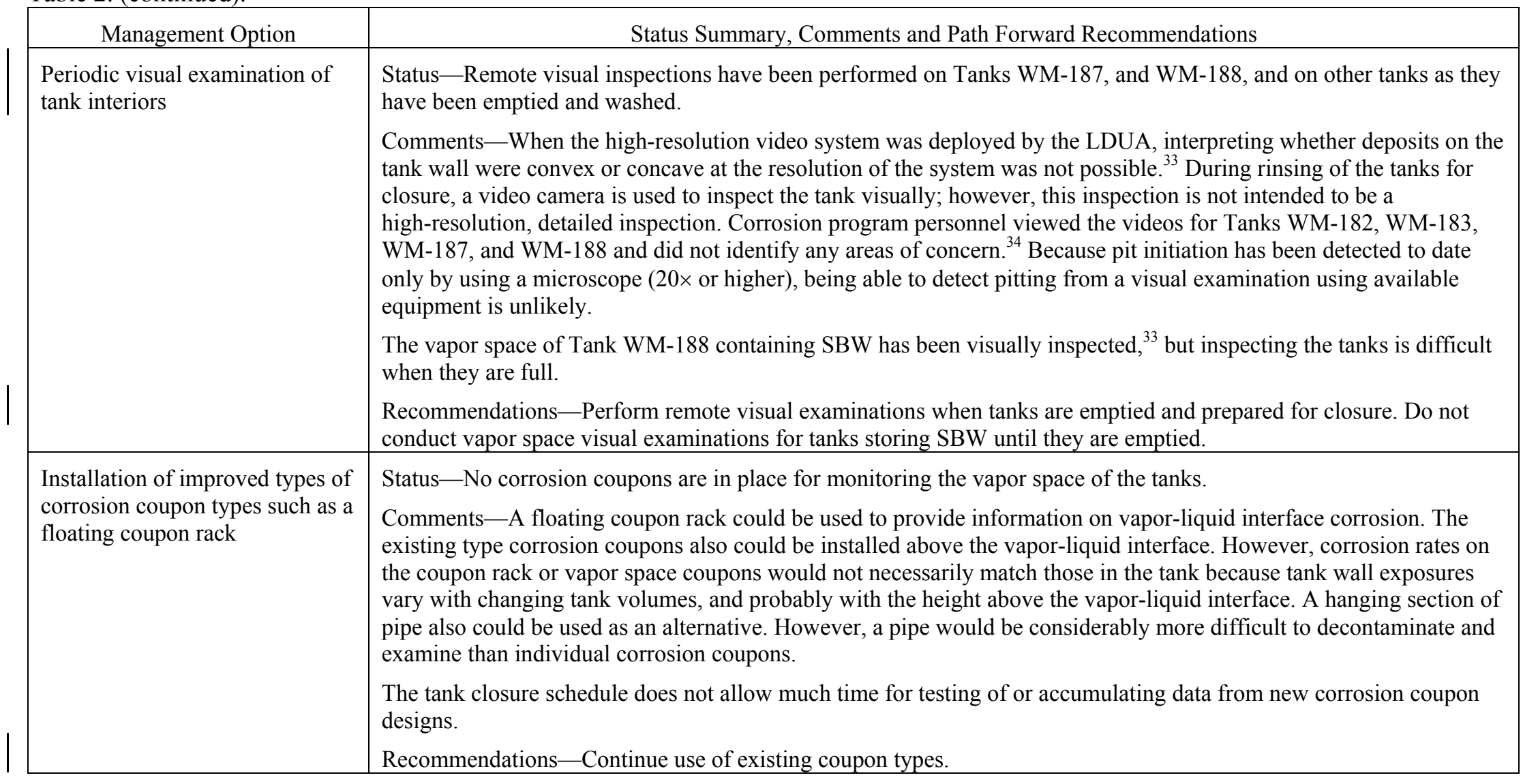


Table 2. (continued).

\begin{tabular}{|c|c|}
\hline Management Option & Status Summary, Comments and Path Forward Recommendations \\
\hline & $\begin{array}{l}\text { Status-Corrosion coupons were removed from the tanks in } 1962,1976,1983 \text {, and } 1988 \text { and from } 1999 \text { to } 2002 \text {. The } \\
\text { original corrosion monitoring plan called for coupon retrieval every } 5 \text { to } 10 \text { years. } \\
\text { Comments-No localized attack was evident on coupons pulled in } 1976,1983 \text {, or } 1988 .^{19,28,29} \text { Some of the coupons } \\
\text { removed from } 1999 \text { to } 2002 \text { have had minimal pit initiation. }{ }^{24-27} \text { Tank life is estimated to be } 48 \text { to } 90 \text { years. Of the } \\
\text { remaining tanks storing SBW, corrosion coupons in WM-187 were pulled in June } 2001 \text { and replaced in July } 2003 \text {; } \\
\text { WM-188 coupons were retrieved in May } 2002 \text {; and WM-189 coupons were pulled in November } 2001 \text {. Corrosion } \\
\text { coupons from several of the tanks that have been emptied have been pulled and cleaned for future inspection. The } \\
\text { CWI life-cycle baseline schedule calls for emptying the remaining tanks in } 2011-2012 \text {. } \\
\text { Recommendations - Continue exposure of the corrosion coupons in Tanks WM-187, WM-188, and WM-189. Pull } \\
\text { and clean corrosion coupons as part of tank washing. Examine the corrosion coupons as resources allow to document } \\
\text { the final condition of the tank corrosion coupons. The tanks have been RCRA closed and these coupons will probably } \\
\text { be discarded unless funds are identified for evaluation. }\end{array}$ \\
\hline $\begin{array}{l}\text { Increased tank chemistry } \\
\text { controls }\end{array}$ & $\begin{array}{l}\text { Status-Chemistry controls and temperature controls are currently in place. Waste compatibility control program } \\
\text { acceptance criteria are defined in PRD-166, "INTEC PEW and Tank Farm Chemical Acceptance Criteria., }{ }^{\circ 0} \mathrm{The} \\
\text { tanks have an operating temperature limit of } 35^{\circ} \mathrm{C}\left(95^{\circ} \mathrm{F}\right) \text {, but are actually operating at approximately } 20^{\circ} \mathrm{C}\left(68^{\circ} \mathrm{F}\right) \\
\text { without the use of cooling coils. } \\
\text { Comments- In } 1988 \text { the tank chemistry changed from HLW from reprocessing to SBW from other activities. } \\
\text { Operation of the ETS and recycling of off-gas scrub solutions also have changed the tank chemistry. }{ }^{57} \text { Laboratory } \\
\text { tests indicate that nitrates }\left(\mathrm{NO}_{3}\right) \text { should be kept at or below } 7 \mathrm{M}^{58} \text { To ensure passivation, rinsewater nitrate levels in } \\
\text { Tank WM- } 187 \text { also should be adjusted to at least } 0.8 \mathrm{M} \text {. Further laboratory tests indicate that there is a cause for } \\
\text { concern about vapor phase corrosion if the Tank Farm waste exceeds a concentration of } 6 \mathrm{M} \text { nitrate and } 1500 \mathrm{ppm} \\
\text { chloride. }{ }^{61} \text { Temperatures of } 20^{\circ} \mathrm{C}\left(68^{\circ} \mathrm{F}\right) \text { do not appear to accelerate localized corrosion } .^{59} \text { No newly generated waste } \\
\text { is being added to the TFF. ETS concentration of WM- } 187 \text { has been evaluated, with the conclusion that further } \\
\text { reducing the volume by } 30,000 \text { gallons would result in nitrate levels of } 5.1 \mathrm{M} \text { and chloride concentrations of } \\
1,050 \text { ppm. These values are within existing operating parameters for the TFF. } \\
\text { Recommendations - Continue to apply the chemistry controls defined in PRD-166. Because no newly generated waste } \\
\text { will be sent to the TFF, and ETS operations are essentially complete, chemistry control actions are minimal at this } \\
\text { time. }\end{array}$ \\
\hline
\end{tabular}


Table 2. (continued).

\begin{tabular}{|c|c|}
\hline Management Option & Status Summary, Comments and Path Forward Recommendations \\
\hline $\begin{array}{l}\text { Development and installation of } \\
\text { an electrochemical noise probe } \\
\text { system to provide the possibility } \\
\text { of real-time indications of pit } \\
\text { development }\end{array}$ & $\begin{array}{l}\text { Status-An electrochemical noise probe system was under development, but program funding was cut and the } \\
\text { equipment has been mothballed. If successful, the system could provide an early warning system for identification of } \\
\text { increases in pit initiation. } \\
\text { Comments-The electrochemical noise probe system is not ready yet for deployment in the TFF. The short remaining } \\
\text { life of the TFF and the state of development of the technology make it questionable whether it can be of use in the } \\
\text { TFF. Corrosion coupon monitoring and laboratory tests, while not real time, have been useful to identify initiation of } \\
\text { localized corrosion. } \\
\text { Recommendations-Do not pursue development of the electrochemical noise system for the TFF. }\end{array}$ \\
\hline \multicolumn{2}{|c|}{$\begin{array}{l}\text { DOE }=\text { U.S. Department of Energy } \\
\text { EMAT }=\text { electromagnetic-acoustic transmitter } \\
\text { ETS }=\text { evaporator tank system } \\
\text { INTEC }=\text { Idaho Nuclear Technology and Engineering Center } \\
\text { LDUA = light-duty utility arm } \\
\text { NDE }=\text { nondestructive examination } \\
\text { PEW }=\text { process equipment waste } \\
\text { PRD }=\text { program requirements document } \\
\text { RCRA = Resource Conservation and Recovery Act } \\
\text { SBW }=\text { sodium-bearing waste } \\
\text { TFF }=\text { Tank Farm Facility }\end{array}$} \\
\hline
\end{tabular}




\section{REFERENCES}

1. DOE O 435.1, "Radioactive Waste Management," U.S. Department of Energy, July 9, 1999.

2. DOE M 435.1-1, "Radioactive Waste Management Manual," U.S. Department of Energy, July $9,1999$.

3. Hovinga, J. E., Lockheed Martin Idaho Technologies Company, to J. L. Lyle, U.S. Department of Energy, Idaho Operations Office, "Completion of HLW Calcination," JEH-06-98, February 23, 1998.

4. DOE G 435.1-1, "Implementation Guide for Use with DOE M 435.1-1," U.S. Department of Energy, July 9, 1999.

5. Bandyopadhyay, K., S. Bush, M. Kassir, B. Mather, P. Shewmon, M. Streicher, B. Thompson, D. van Rooyen, and J. Weeks, Guidelines for Development of Structural Integrity Programs for DOE High-Level Waste Storage Tanks, BNL-52527, Brookhaven National Laboratory, Upton, New York, January 1997.

6. Palmer, W. B., P. A. Anderson, W. J. Dirk, M. D. Staiger, M. C. Swenson, and F. S. Ward, Status and Estimated Life of the 300,000-Gallon INTEC Tanks, INEEL/EXT-99-00743, Rev. 1, Idaho National Engineering and Environmental Laboratory, Lockheed Martin Idaho Technologies Company, Idaho Falls, Idaho, November 1999.

7. Bryant, Jeffrey, and Joseph A. Nenni, Structural Integrity Program for the Calcined Solids Storage Facilities at the Idaho Nuclear Technology and Engineering Center, INEEL/EXT-02-01548, Rev. 1, Idaho National Engineering and Environmental Laboratory, Bechtel BWXT Idaho, LLC, Idaho Falls, Idaho, August 2008.

8. U.S. Department of Energy Idaho Operations Office, Operable Unit 3-14 Tank Farm Soil and Groundwater Phase I Remedial Investigation/Feasibility Study Work Plan, DOE/ID-10676, Rev. 0, Idaho National Engineering and Environmental Laboratory, Bechtel BWXT Idaho, LLC, Idaho Falls, Idaho, 2000.

9. INTEC Operations Web site, http://intecops/.

10. Lyle, J. F., U.S. Department of Energy, Idaho Operations Office, to C. F. York, Lockheed Martin Idaho Nuclear Company, "ICPP Waste Minimization Plan (OPE-SFP-97-308)," September 15, 1997.

11. U. S. Department of Energy Idaho Operations Office, Environmental Management Performance Management Plan for Accelerating Cleanup of the Idaho National Engineering and Environmental Laboratory, DOE/ID-11006, Idaho Falls, Idaho, July 2002.

12. Monson, Brian, Idaho Department of Health and Welfare, Division of Environmental Quality, to Bob Rothman, U.S. Department of Energy Idaho Operations Office, "Notice of Noncompliance Consent Order, Idaho Code § 39-4413," April 7, 1992.

13. Valentine, J. H., Bechtel BWXT Idaho, LLC, to Joel T. Case, U.S. Department of Energy Idaho Operations Office, "Achieving the Notice of Noncompliance Consent Order Milestone to Empty the INTEC Tank Farm Pillar and Panel Vaulted Tanks," CCN29920, April 3, 2002.

14. Cory, W. N., Idaho Department of Health and Welfare, Division of Environmental Quality, to J. M. Wilcynski, U.S. Department of Energy Idaho Operations Office, and C. C. Clarke, U.S. Environmental Protection Agency, "Second Modification to the Notice of Noncompliance Consent Order," August 18, 1998. 
15. U.S. Department of Energy, Environmental Management; U.S. Department of the Navy, Naval Nuclear Propulsion Program; and the State of Idaho, Settlement Agreement, October 17, 1995.

16. Peckner, D., and I. M. Bernstein, Handbook of Stainless Steels, Chapter 1, McGraw-Hill, February 23, 1998.

17. Iron and Steel Society, Steel Products Manual, Stainless and Heat Resisting Steels, Iron and Steel Society, 1990.

18. Hoffman, T. L., Corrosion Evaluation of Stainless Steels Exposed in ICPP High-Level Radioactive Waste Tanks, IDO-14600, Atomic Energy Commission, Idaho Operations, Idaho Falls, Idaho, December 1962.

19. Zimmerman, C. A., Corrosion Evaluation of ICPP High-Level Liquid Waste Storage Tanks, WINCO-1064, Idaho National Engineering Laboratory, Westinghouse Idaho Nuclear Company, Idaho Falls, Idaho, April 1989.

| 20. International Technology Corporation, Interim Tank Assessment Radioactive Waste Tanks with RCRA Requirements of 40 CFR 265.191 and 40 CFR 270.11 Engineers Report, December 1990.

21. 40 CFR 265.191, Title 40, "Protection of Environment," Part 265, "Interim Status Standards for Owners and Operators of Hazardous Waste Treatment, Storage, and Disposal Facilities," Subpart J, "Tank Systems," Section 191, "Assessment of Existing Tank System's Integrity," Code of Federal Regulations, Office of the Federal Register, February 13, 2002.

| 22. 40 CFR 270, 2002, Title 40, "Protection of Environment," Part 270, "EPA Administered Permit Programs: the Hazardous Waste Permit Program," Subpart B, "Permit Application," Section .11, "Signatories to Permit Applications and Reports," Code of Federal Regulations, Office of the Federal Register.

23. MCP-1117, "INTEC Cathodic Protection System Management," Rev. 6, October 12, 2006.

24. Dirk, W. J., and P. A. Anderson, Corrosion Evaluation of INTEC Waste Storage Tank WM-182, INEEL/EXT-99-01109, Idaho National Engineering and Environmental Laboratory, Bechtel BWXT Idaho, LLC, Idaho Falls, Idaho, November 1999.

| 25. Dirk, W. J. and L. L. Torres, Corrosion Evaluation of INTEC Waste Storage Tank WM-183, INEEL/EXT-01-00262, Idaho National Engineering and Environmental Laboratory, Bechtel BWXT Idaho, LLC, Idaho Falls, Idaho, March 2001.

| 26. Yoder, T. S. and B. C. Norby, Corrosion Evaluation of INTEC Waste Storage Tanks WM-187, $W M-188, W M-189$, and $W M-180$, INEEL/INT-02-01150, Idaho National Engineering and Environmental Laboratory, Bechtel BWXT Idaho, LLC, Idaho Falls, Idaho, September 2002.

| 27. Yoder, T. S., to J. W. Bryant, "Re-Evaluation of Tank WM-182 Corrosion Coupons," TSY-06-02, October 30, 2002.

28. Hoffman, T. L., B. C. Norby, R. E. Mizia, and C. A. Zimmerman, Evaluation of Stainless Steel Tank Corrosion in ICPP High Level Radioactive Waste Service, ENICO-1131, Idaho National Engineering Laboratory, Exxon Nuclear Chemical Company, Idaho Falls, Idaho, April 1983.

| 29. Hoffman, T. L., Corrosion Evaluation of Stainless Steels in ICPP High-Level Radioactive Waste Service, ICP-1072, Idaho National Engineering Laboratory, Allied Chemical Corporation, Idaho Falls, Idaho, June 1976.

| 30. API RP 579, Recommended Practice for Fitness-for-Service, $1^{\text {st }}$ ed., American Petroleum Institute, January 1, 2000.

31. CC Technologies, Final Report C 2106-01C INTEC Tank Farm Life Assessment, October 10, 2002. 
32. Idaho National Engineering and Environmental Laboratory, "ICPP Tank Farm HLLWT Visual Inspections," Video Tracking Number INEEL 1999-EXT-193, Bechtel BWXT Idaho, LLC, Idaho Falls, Idaho, January 12, 1994.

33. Patterson, M., Light Duty Utility Arm Deployment in Tank WM-188, INEEL/EXT-99-01302, 2001 Idaho National Engineering and Environmental Laboratory, Bechtel BWXT Idaho, LLC, Idaho Falls, Idaho, December 1999.

34. Yoder, T. S., to J. W. Bryant, "General Corrosion Observations from Video Inspections of WM-182, WM-183, WM-187 and WM-188, TSY-02-02," July 8, 2002.

35. Beck, J. T., Field Deployment Report for the Vault Sump Sampler, INEEL/EXT-02-00031, Idaho National Engineering and Environmental Laboratory, Bechtel BWXT Idaho, LLC, Idaho Falls, Idaho, February 2002.

| 36. "ICP Production Monthly Report No. 164, October 27 through November 26, 1973," Amb-79-73, Allied Chemical Corporation, Idaho Falls, Idaho, December 5, 1973.

37. Wagner, E. P., Process Description and Operating History for the CPP-601/640/627 Fuel Reprocessing Complex at the Idaho National Engineering and Environmental Laboratory, INEEL/EXT-99-00400, Idaho National Engineering and Environmental Laboratory, Lockheed Martin Idaho Technologies Company, Idaho Falls, Idaho, 1999.

| 38. U.S. Department of Energy, Idaho High-Level Waste \& Facilities Disposition Environmental Impact Statement, DOE/EIS-0287, Idaho Operations Office, Idaho Falls, Idaho, September 2002.

39. Not used.

40. PRD-166, "INTEC PEW and Tank Farm Chemical Acceptance Criteria," Rev. 15, November 4, 2009.

41. EQE International, Seismic Analysis of Waste Tank Vaults at the Idaho Chemical Processing Plant, November 1988.

42. Blume, J. A., and Associates, Seismic Analysis and Evaluation of Waste Tank Vaults WM-180 and WM-187 Through WM-190 at the Idaho Chemical Processing Plant, Idaho National Engineering Laboratory, Job Number 66263, October 1990.

| 43. Advanced Engineering Consultants, Third Party Review of Seismic Analysis and Evaluation of Waste Tank Vaults WM-180 \& WM-181 and WM-187 Through WM-190, Job Number 0128-00, San Francisco, October 1990.

| 44. Advanced Engineering Consultants, Seismic Analysis and Evaluation of Octagonal Waste Tank Vaults WM-180 \& WM-181 at the Idaho Chemical Processing Plant, Job Number 0129, San Francisco, February 1991.

| 45. Advanced Engineering Consultants, Seismic Assessment of Post and Panel Waste Tank Vaults WM-182 to WM-186, San Francisco, June 10, 1991.

| 46. Advanced Engineering Consultants, Addendum to Chapter 4 of "Seismic Analysis and Evaluation of Waste Tank Vaults WM-180 \& WM-181 and WM-187 Through WM-190 at the Idaho Chemical Processing Plant, Idaho National Engineering Laboratory, San Francisco, March 1993.

| 47. EQE International, Independent Review of Additional Seismic Analysis and Evaluation of Waste Tank Vaults WM-180 \& WM-181 and WM-187 Through WM-190 at the Idaho Chemical Processing Plant, Idaho National Engineering Laboratory, Job Number 52123.06, March 1994.

| 48. Advanced Engineering Consultants, Letter Report on Seismic Evaluation of Anchorages for ICPP Tank Farm Tanks WM-180 and WM-181, Job Number 5005, San Francisco, January 29, 1996. 
49. Not used.

50. Swenson, M. C., to P. K. Yeary, "INTEC Tank Farm Valve Box Modification Plans and Consent Order Requirements," MCS-09-00, November 6, 2000.

| 51. Bryant, J. W., to J. I. Pruitt, "Trip Report - $3^{\text {rd }}$ Tank Integrity Workshop - December 10-12, 2002," JWB-02-02, December 16, 2002.

| 52. Commander, R. E., Investigation Report ICPP Tank Farm Contaminated Soil Incident of September 18, 1975, Idaho National Engineering Laboratory, Allied Chemical Corporation, Idaho Falls, Idaho.

| 53. Newby, B. J., to V. C. Maio, "Penetration Rate of Fluorinel Waste Into Concrete,” Nby-11-89, March 30, 1989.

| 54. Brewer, K. N., to G. R. Franz, "Concrete Encased Pipe Compatibility Study,” KNB-09-90, October 18, 1990.

| 55. Newby, B. J., to L. F. Ermold, "Grout Penetration Rate of Fluorinel Waste Based on Concrete Studies," June 1, 1990.

| 56. Brewer, K. N., to C. V. Park, "FPR Concrete Encased Pipe Compatibility Study," KNB-08-90, October 5, 1990.

| 57. Mizia, R. E., to J. I. Pruitt and J. W. Bryant, "INTEC HLW Tank Inspection Schedule," REM-01-02, December 12, 2002.

| 58. Yoder, T. S., to J. M. White, "Results of Secondary WM-187, WM-188, and WM-189 Concentrated Waste Corrosion Testing," TSY-01-02, April 22, 2002.

| 59. Lister, T., Electrochemical Noise Testing Report \#2, Experiments Covering August-November 2002, Idaho National Engineering and Environmental Laboratory, Bechtel BWXT Idaho, LLC, Idaho Falls, Idaho, November 21, 2002.

60. Bryant, Jeffrey, Joseph A. Nenni, Timothy S. Yoder, Structural Integrity Program for the 300,000gallon Radioactive Liquid Waste Storage Tanks at the Idaho Nuclear Technology and Engineering Center, INEEL/EXT-02-01549, Idaho National Engineering and Environmental Laboratory, Bechtel BWXT Idaho, LLC, Idaho Falls, Idaho, April 2003.

61. Yoder, T. S, to J. M. White, "FY2003 INTEC Tank Farm Concentrated Waste Corrosion Testing," TSY-03-03, September 25, 2003.

62. DVD: The INTEC Tank Farm: Cleanup Progress, December 2004. 


\section{Appendix A Tank History}


A-2 


\section{Appendix A}

\section{Tank History}

A brief history of each Tank Farm Facility (TFF) tank is presented in this appendix. Grouting of the WM-180 through WM-186 tanks and vaults was completed on March 19, 2008.

Most of the liquid waste that has been contained in the TFF is either classified as aluminum or zirconium-clad fuel reprocessing raffinate or sodium-bearing waste (SBW). Table A-1 shows typical chemical compositions for these waste types.

$\underline{\text { Table A-1. Typical chemical waste chemical composition (in moles/liter except where noted). }{ }^{1}}$

\begin{tabular}{|c|c|c|c|}
\hline Component & $\begin{array}{c}\text { Aluminum Fuel } \\
\text { Raffinate }\end{array}$ & $\begin{array}{c}\text { Zirconium Fuel } \\
\text { Raffinate }\end{array}$ & $\begin{array}{c}\text { Sodium-Bearing } \\
\text { Waste }\end{array}$ \\
\hline Acid & 0.81 & 1.4 & 1.28 \\
\hline Aluminum & 1.5 & 0.68 & 0.57 \\
\hline Boron & (a) & 0.19 & 0.017 \\
\hline Cadmium & & $0 / 0.11(b)$ & 0.001 \\
\hline Chloride & & & 0.028 \\
\hline Chromium & & 0.015 & \\
\hline Fluoride & & 3.20 & 0.04 \\
\hline Iron & 0.01 & 0.007 & 0.002 \\
\hline Mercury & 0.02 & & 0.0013 \\
\hline Nitrate & 5.40 & 2.30 & 4.50 \\
\hline Potassium & & 0.003 & 0.017 \\
\hline Sodium & 0.06 & 0.017 & 1.50 \\
\hline Sulfate & & & 0.043 \\
\hline Tin & & 0.005 & \\
\hline Uranium (mg/L) & 1.3 & 1.3 & 66.2 \\
\hline Zirconium & & 0.41 & \\
\hline Undissolved solids (g/L) & & 2.0 & 2.4 \\
\hline Specific gravity & 1.28 & 1.20 & 1.25 \\
\hline
\end{tabular}




\section{Tank WM-180}

Tank WM-180 is one of the two oldest of the waste storage tanks at the Idaho Nuclear Technology and Engineering Center (INTEC) and was put into service in 1954. It is contained in an octagonal, poured-in-place reinforced concrete vault. The tank is $15 \mathrm{~m}(50 \mathrm{ft})$ in diameter. It is quite similar to the other tanks except that it is constructed of Type 347 stainless steel, rather than Type 304L, and its wall is $7 \mathrm{~m}(23 \mathrm{ft})$ high rather than $6.4 \mathrm{~m} \mathrm{(21} \mathrm{ft)} \mathrm{high} \mathrm{as} \mathrm{in} \mathrm{the} \mathrm{later} \mathrm{tanks.} \mathrm{This} \mathrm{extra} \mathrm{wall} \mathrm{height} \mathrm{gives} \mathrm{this} \mathrm{tank} \mathrm{a}$ volume of 318,000 gal rather than 300,000 gal, but the operating volume is not normally allowed to exceed 285,000 gal. The plate for the tank was annealed and pickled before shipment and welding. ${ }^{2}$ The tank is equipped with Type 304L cooling coils. The tank has been filled several times and has contained aluminum fuel reprocessing raffinate and SBW (see Figure A-1). In 1967, Tank WM-180 was emptied, then refilled with SBW and emptied in 1986 before again refilling with SBW. The tank was emptied to its heel in 2004. Tank cleaning operations were completed in October 2004. Grouting of this tank has been completed.

WM-180

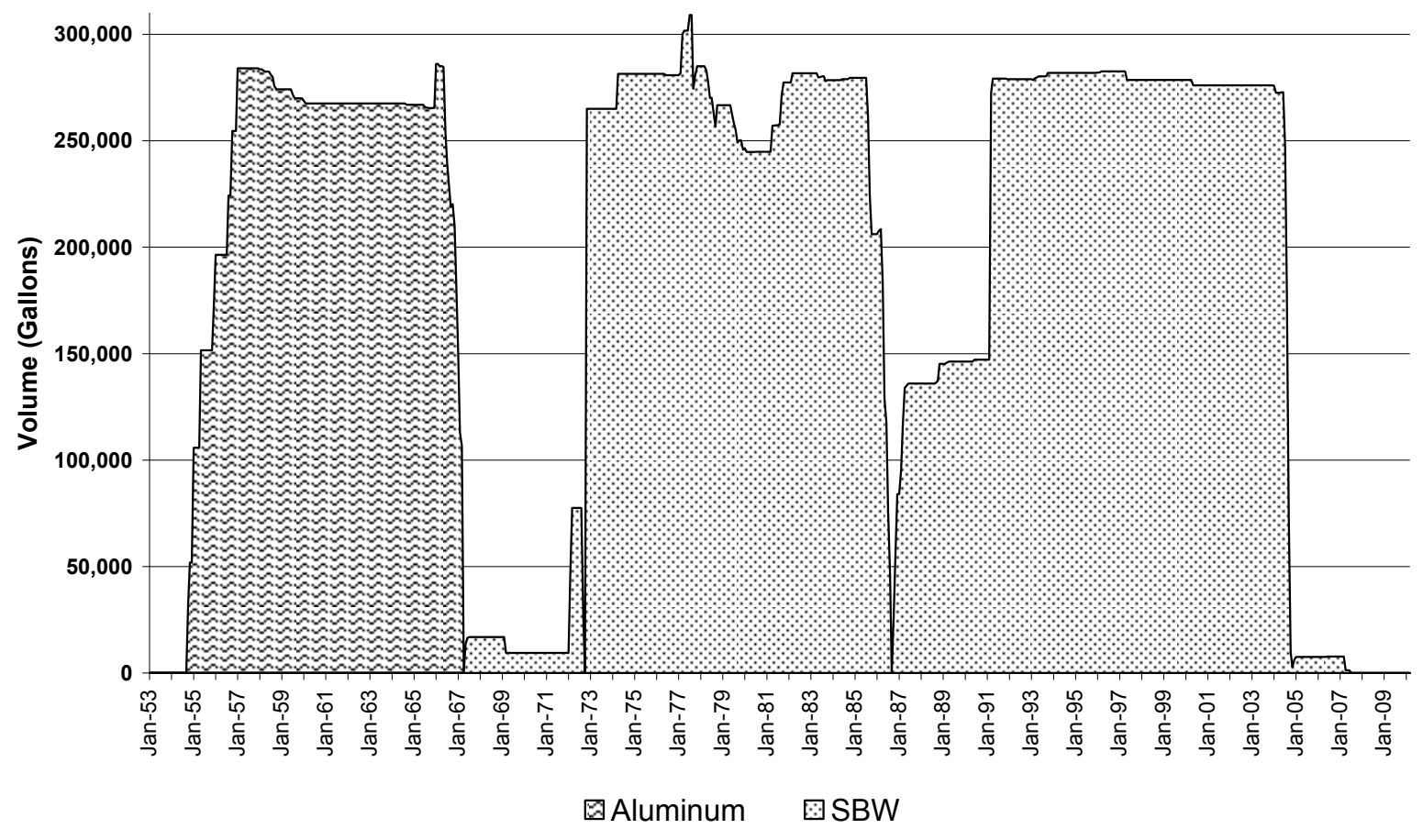

Figure A-2. Historical operation of Tank WM-180. 


\section{Tank WM-181}

Tank WM-181 is one of the two oldest Tank Farm tanks at the INTEC. It was constructed in 1951 through 1952 and was put into service in 1953. It is contained in an octagonal, poured-in-place reinforced concrete vault. The tank is $15 \mathrm{~m}(50 \mathrm{ft})$ in diameter. It is similar to the other waste storage tanks at the

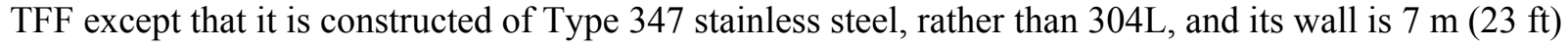
high rather than $6.4 \mathrm{~m}(21 \mathrm{ft})$ high. This extra wall height gives this tank a volume of 318,000 gal rather than 300,000 gal, but the operating volume is not normally allowed to exceed 285,000 gal. The plate for the tank was annealed and pickled before shipment and welding. The tank does not contain cooling coils. The tank has been filled and emptied several times and has contained only SBW (see Figure A-2). The tank was emptied to heel level in December 2001 by blending with WM-184 and WM-186 waste. Tank cleaning operations were completed in May 2004. Grouting of this tank has been completed.

WM-181

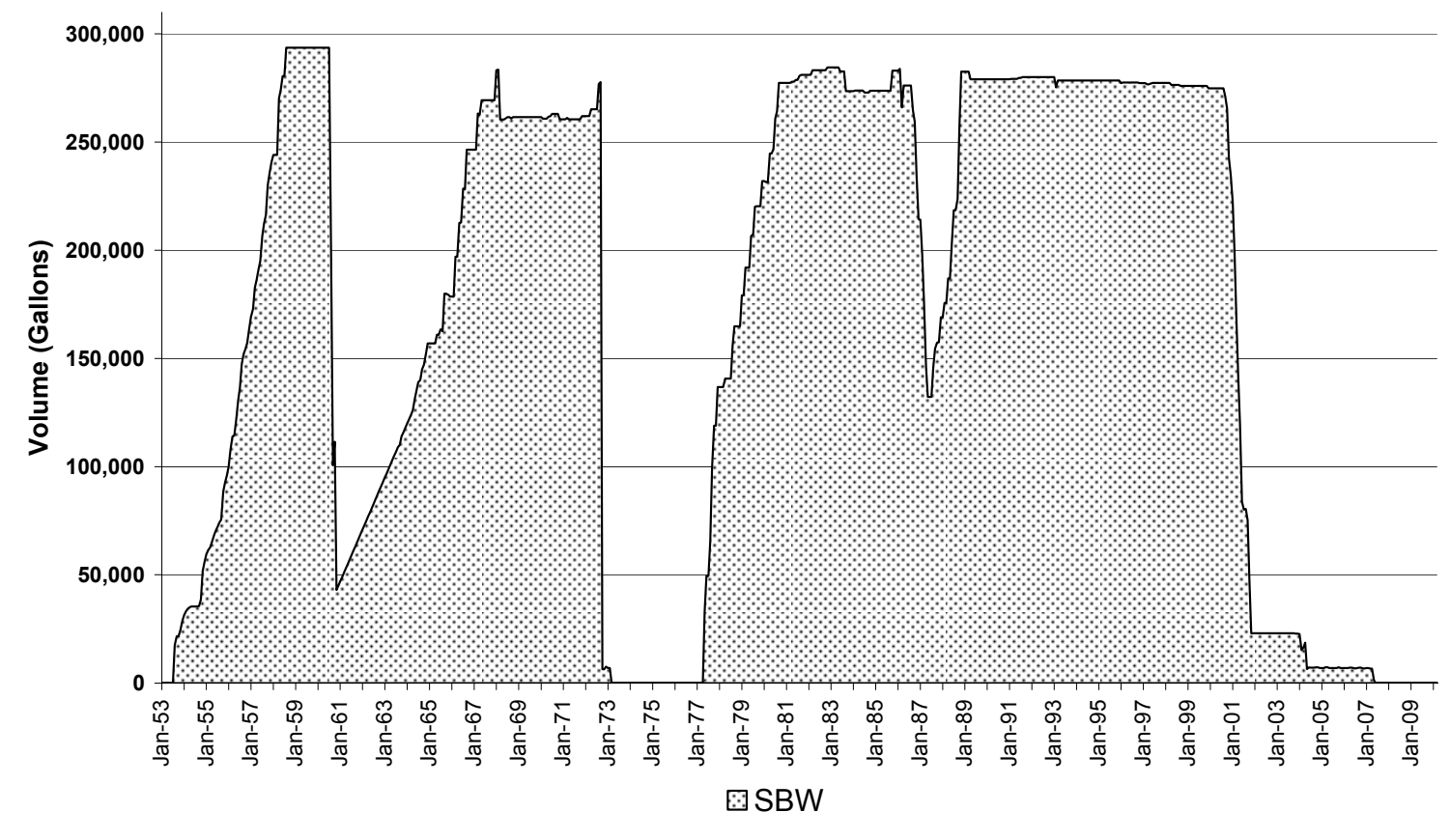

Figure A-2. Historical operation of Tank WM-181. 


\section{Tank WM-182}

Tank WM-182 is one of the five tanks, constructed from 1954 to 1957, contained in prefabricated

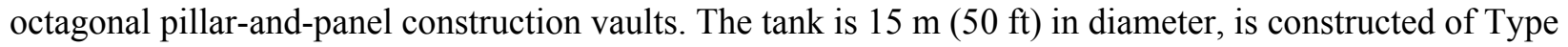
304L stainless steel, and has a sidewall that is $6.4 \mathrm{~m}(21 \mathrm{ft})$ high. The tank has a volume of 300,000 gal, but the operating volume is not allowed to exceed 285,000 gal. The tank is equipped with Type $304 \mathrm{~L}$ cooling coils. This tank was put into service in 1955 and, by 1959, was filled with aluminum fuel reprocessing raffinate. This waste was calcined in 1966 to 1968 and the tank was emptied to the heel. Figure A-3 shows that the tank was refilled and emptied three more times, twice with zirconium fuel reprocessing raffinate and once with aluminum fuel reprocessing raffinate. Tank WM-182 was emptied in 1993, and then flushed with SBW. The tank was again emptied before a corrosion coupon retrieval and tank inspection in 1999. The video inspection in October 1999 showed this tank to contain approximately $10 \mathrm{~cm}$ (4 in.) of solids in its heel. The solids were sent to Tank WM-187, and tank cleaning operations were completed in September 2002. Grouting of this tank has been completed.

WM-182

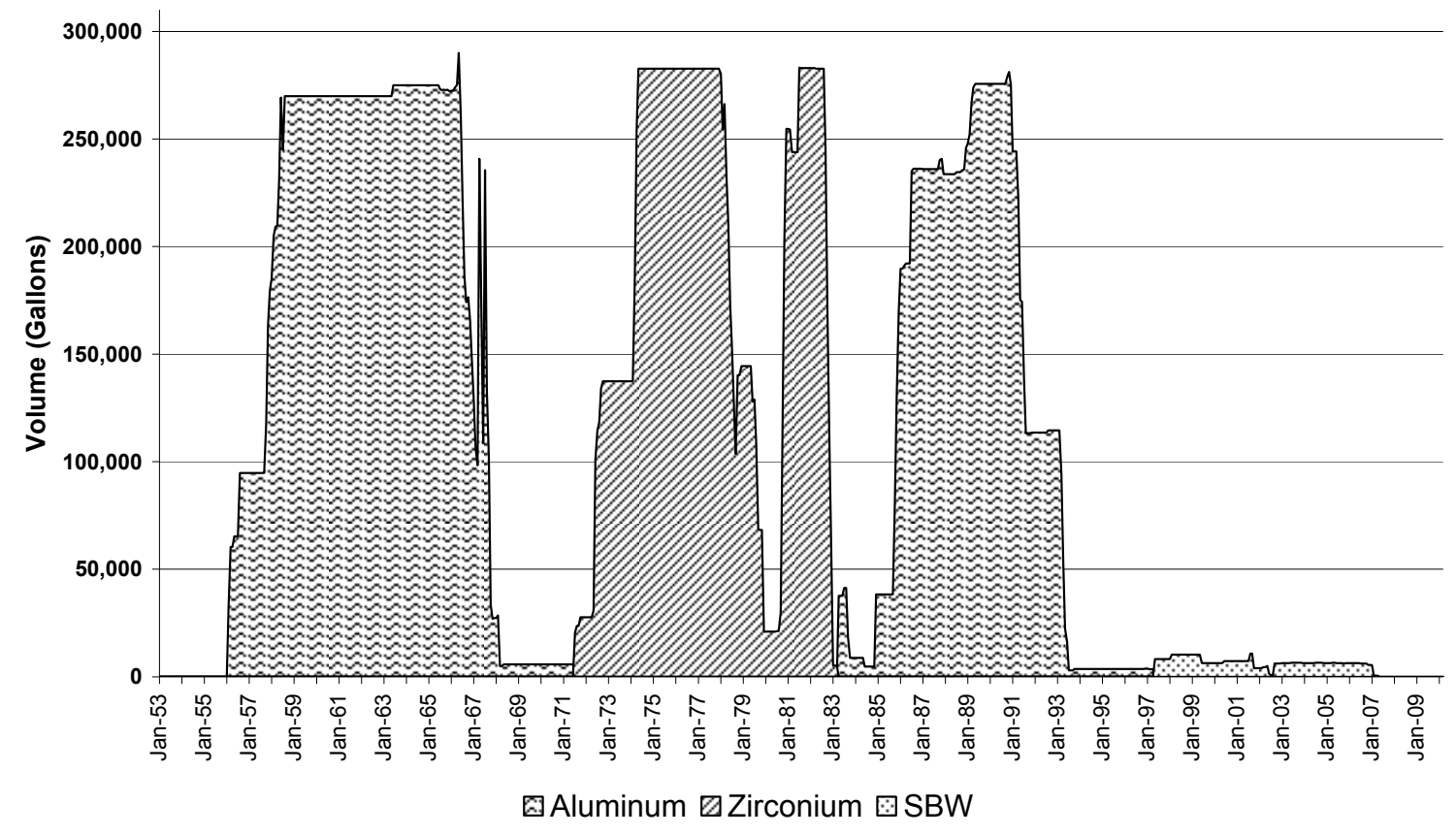

Figure A-3. Historical operation of Tank WM-182. 


\section{Tank WM-183}

The operational history of Tank WM-183, a pillar-and-panel-vaulted tank, is shown in Figure A-4. This tank was put into service in 1958. It is contained in an octagonal, pillar-and-panel concrete vault. The tank is $15 \mathrm{~m}(50 \mathrm{ft})$ in diameter, is constructed of Type $304 \mathrm{~L}$ stainless steel, and has a sidewall that is

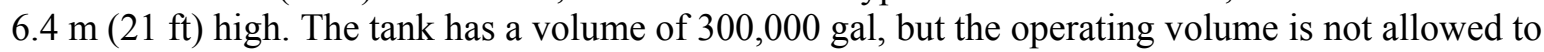
exceed 285,000 gal. The tank is equipped with Type 304L cooling coils. The tank has been filled several times and has contained aluminum and stainless steel fuel reprocessing raffinate, bottoms from the original High Level Liquid Waste Evaporator (WC-114) in the Waste Calcining Facility (CPP-633), and SBW. Tank WM-183 was emptied of a solution composed of $25 \%$ aluminum and $75 \%$ SBW solution in late 1996, and was then partially filled with SBW. This tank was again emptied to a 76-cm (30-in.) waste depth in December 1999 before a corrosion coupon retrieval and tank inspection. Video inspections in December 1999 and January 2000 (after lowering the waste depth to the heel level of $30 \mathrm{~cm} \mathrm{[12} \mathrm{in.])}$ showed this tank to contain approximately $12 \mathrm{~cm}$ (5 in.) of solids in its heel. Tank cleaning operations were completed in March 2003. In 2004, some solution leaked into the tank. As a result, the tank was recleaned and sampled. Grouting of this tank has been completed.

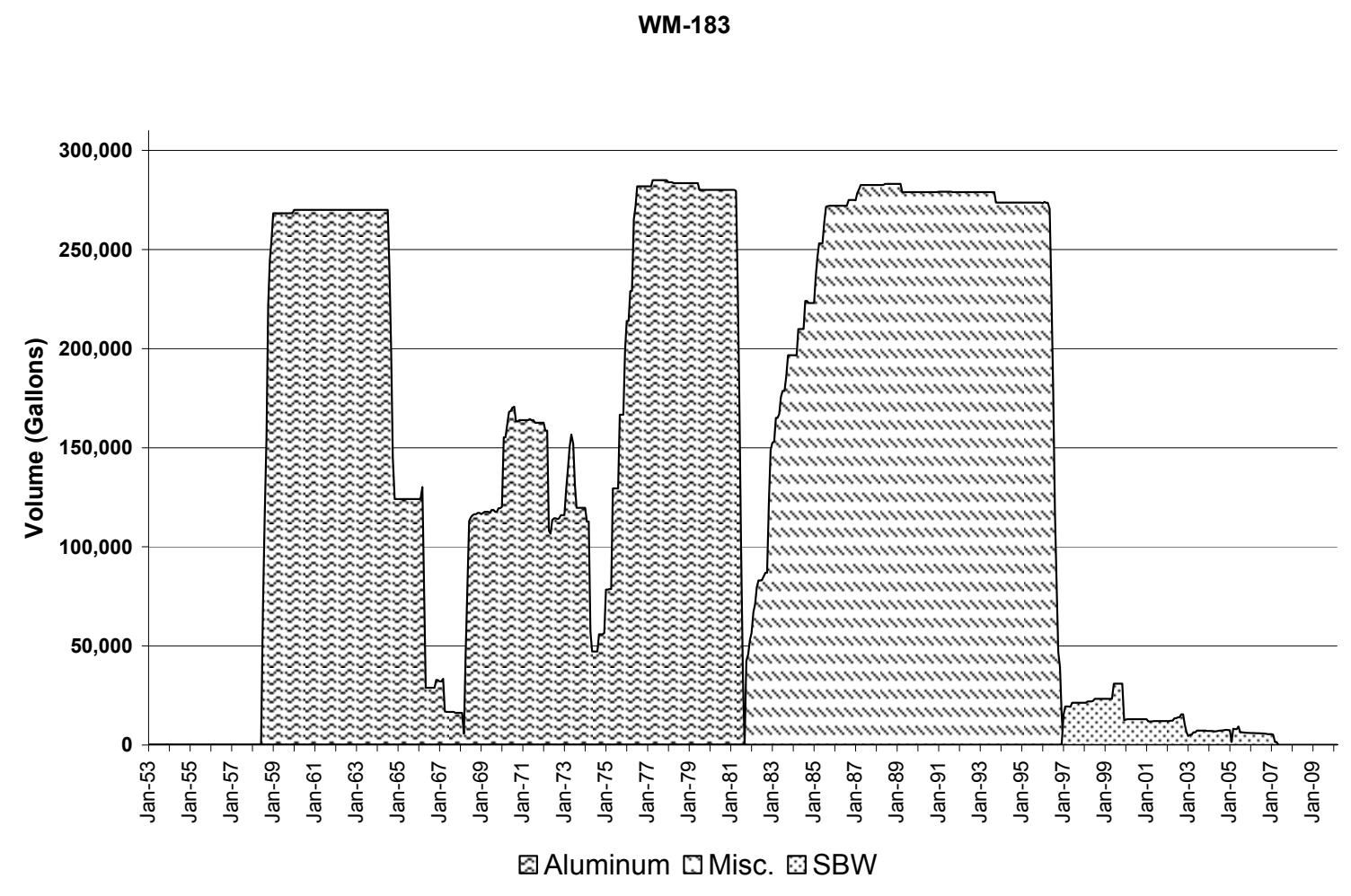

Figure A-4. Historical operation of Tank WM-183. 


\section{Tank WM-184}

Pillar-and-panel-vaulted tank WM-184 was put into service in 1958. It is contained in an octagonal, pillar-and-panel concrete vault. The tank is $15 \mathrm{~m} \mathrm{(50} \mathrm{ft)} \mathrm{in} \mathrm{diameter,} \mathrm{is} \mathrm{constructed} \mathrm{of} \mathrm{Type} \mathrm{304L} \mathrm{stainless}$ steel, and has a sidewall that is $6.4 \mathrm{~m} \mathrm{(21} \mathrm{ft)} \mathrm{high.} \mathrm{The} \mathrm{tank} \mathrm{has} \mathrm{a} \mathrm{nominal} \mathrm{volume} \mathrm{of} \mathrm{300,000} \mathrm{gal,} \mathrm{but} \mathrm{the}$ operating volume is not allowed to exceed 285,000 gal. The tank does not contain cooling coils. The operational history of the tank is shown in Figure A-5. As noted in the figure, the tank was filled in the late 1950s with SBW. It remained full, or nearly full, until 1990 when half of its contents were transferred to WM-180. It was then refilled with SBW from Process Equipment Waste Evaporator bottoms. The tank was emptied to heel level in December 2001. Tank cleaning operations were completed in December 2003. Grouting of this tank has been completed.

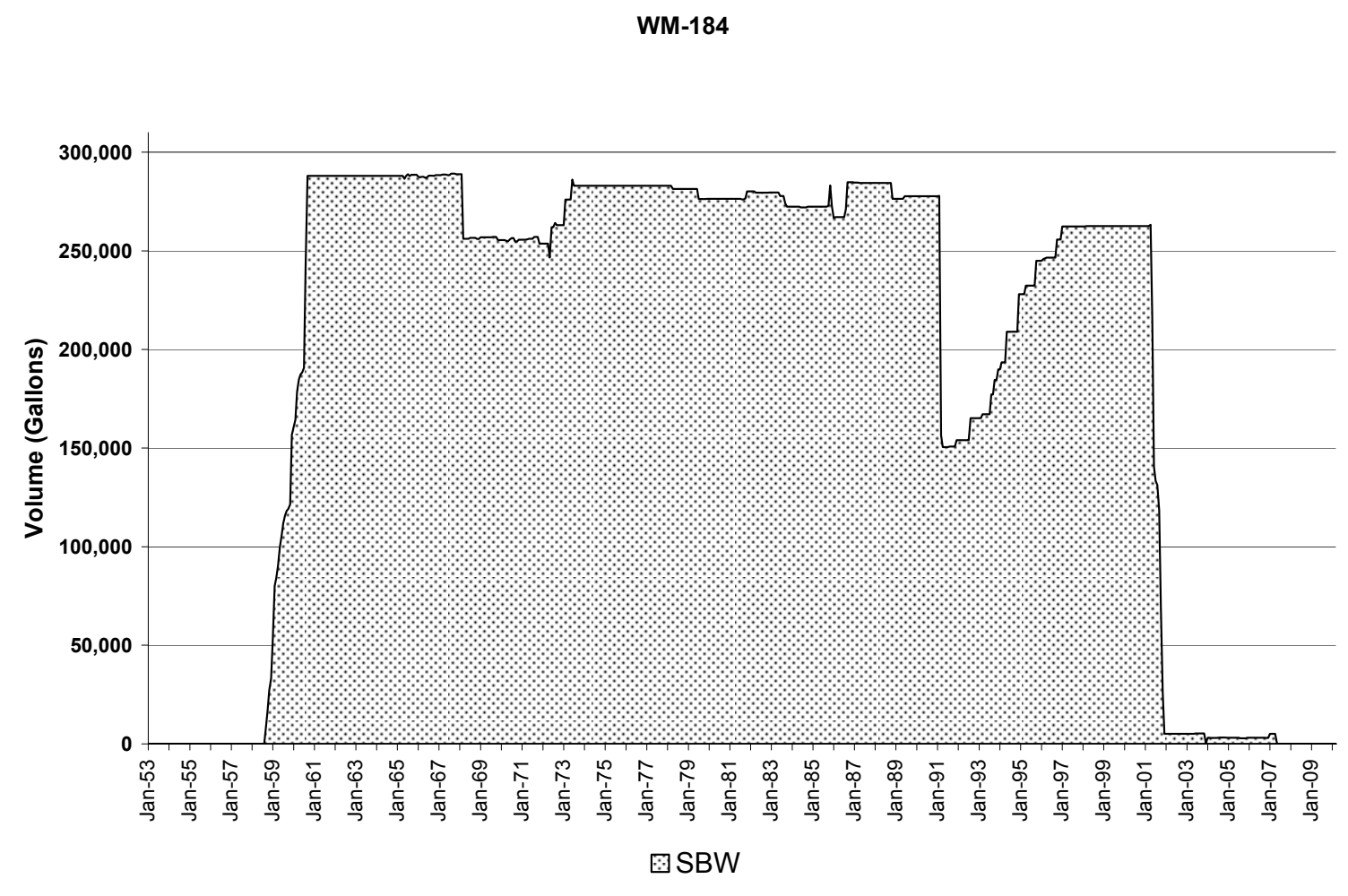

Figure A-5. Historical operation of Tank WM-184. 


\section{Tank WM-185}

Tank WM-185 was put into service in 1959. It is contained in an octagonal, pillar-and-panel

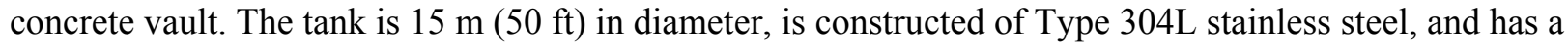
sidewall that is $6.4 \mathrm{~m}(21 \mathrm{ft})$ high. The tank has a nominal volume of 300,000 gal, but the operating volume is not allowed to exceed 285,000 gal. The tank is equipped with Type 304L cooling coils. The operational history of WM-185 is shown in Figure A-6. The tank was filled and emptied several times with a variety of waste types including aluminum and zirconium fuel reprocessing raffinate, and SBW. Tank WM-185 was emptied in 1985 before being partially refilled with SBW. It was again emptied in January 2002. Tank cleaning operations were completed in October 2003. Grouting of this tank has been completed.

WM-185

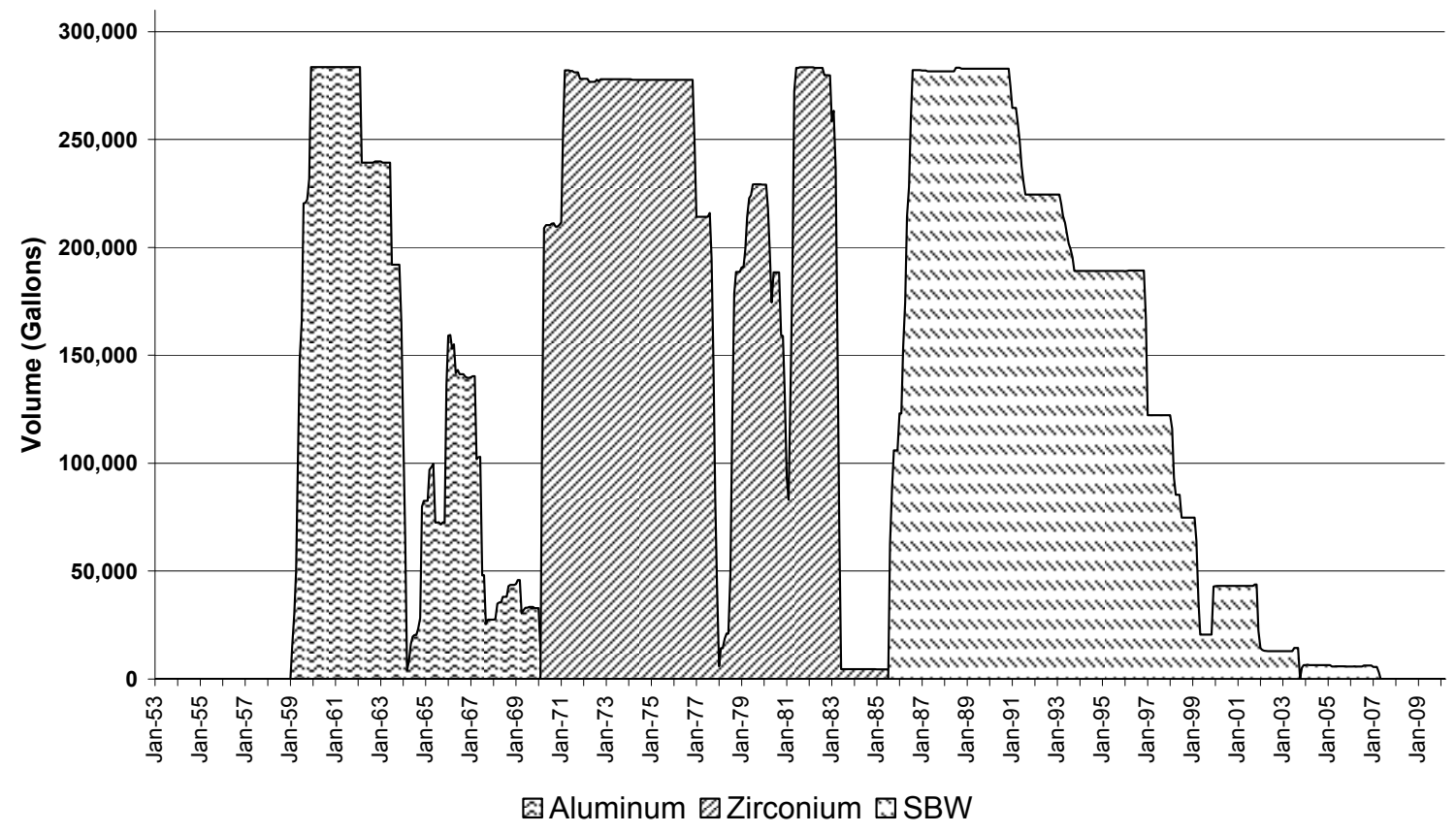

Figure A-6. Historical operation of Tank WM-185. 


\section{Tank WM-186}

In 1962, Tank WM-186 was the final pillar-and-panel-vaulted tank put into service. The tank is

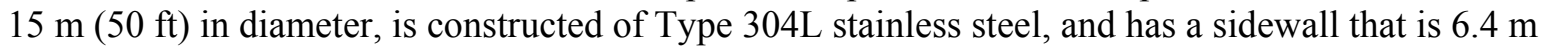
$(21 \mathrm{ft})$ high. The tank has a volume of 300,000 gal, but the operating volume is not allowed to exceed 285,000 gal. The tank does not contain cooling coils. In 1962 the tank was partially filled with aluminum fuel reprocessing raffinate from Tank WM-187 to lower the level in the tank in response to a suspected leak. Subsequently, a determination was made that solution entered into the Tank WM-187 vault, as a result of siphoning, from Tank WM-187 through the vault sump jet piping to the tank. However, no leak | actually occurred. ${ }^{3}$ The raffinate solution was transferred subsequently to WM-182 in 1967. The tank was then filled with SBW. About half of the volume was calcined in the late 1980s and the tank was refilled with SBW from Process Equipment Waste Evaporator bottoms and other sources. The tank was emptied to heel level in May 2001. Tank cleaning operations were completed in November 2003. Grouting of this tank has been completed. The operational history of this tank is shown in Figure A-7. .

WM-186

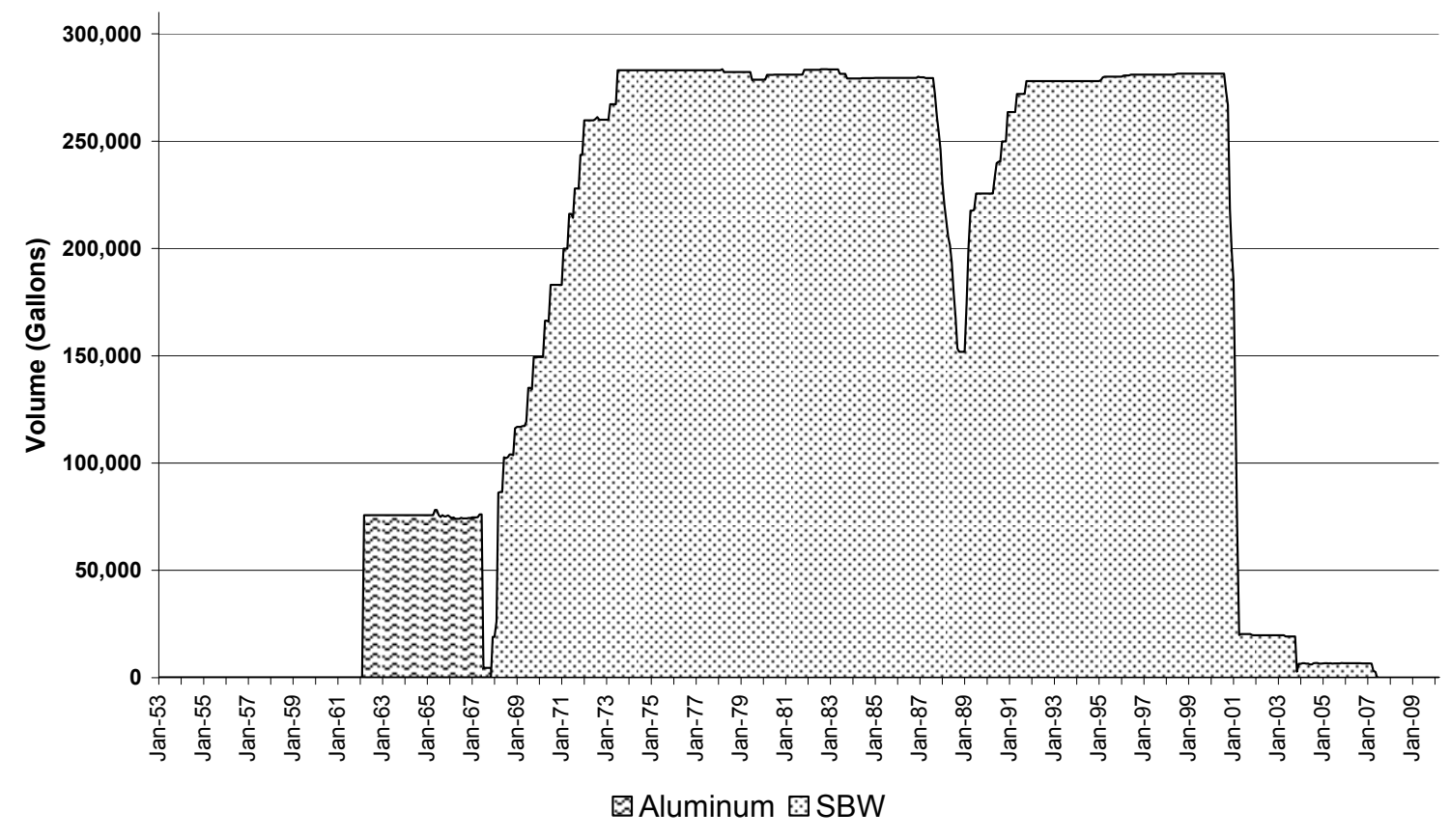

Figure A-7. Historical operation of Tank WM-186. 


\section{Tank WM-187}

In 1959, Tank WM-187 was put into service. Tank WM-187 is contained in a square reinforced concrete vault. The tank is $15 \mathrm{~m}(50 \mathrm{ft})$ in diameter, is constructed of Type 304L stainless steel, and has a sidewall that is $6.4 \mathrm{~m}(21 \mathrm{ft})$ high. The tank has a volume of 300,000 gal, but the operating volume is not allowed to exceed 285,000 gal. The tank is equipped with Type 304L cooling coils and was designed to store reprocessing raffinate. Tank WM-187 was filled several times with aluminum and zirconium fuel reprocessing raffinate as well decontamination waste and SBW. Tank WM-187 was emptied in 1994, partially refilled with SBW, and was emptied twice since then. The tank has been used to collect SBW solutions and solids generated during tank closure rinses. Solution in Tank WM-187 has been concentrated and returned to the tank to await final treatment at the Integrated Waste Treatment Unit process. The operational history of this tank is shown in Figure A-8.

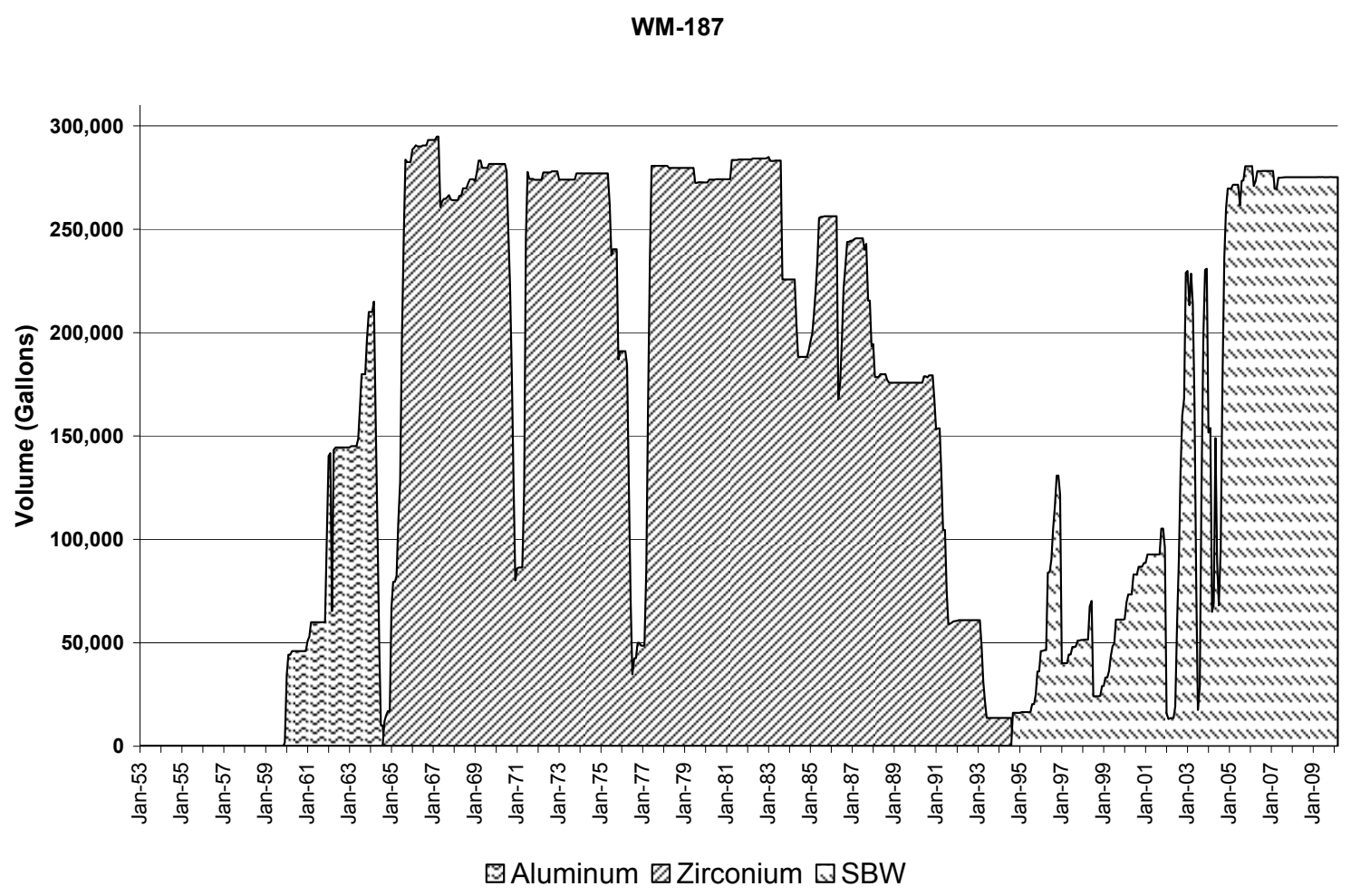

Figure A-8. Historical operation of Tank WM-187. 


\section{Tank WM-188}

Tank WM-188 was put into service in 1962. It is contained in a square reinforced concrete vault.

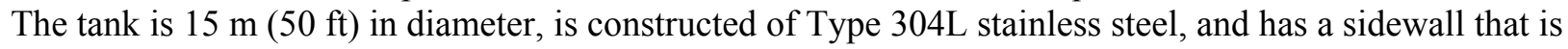

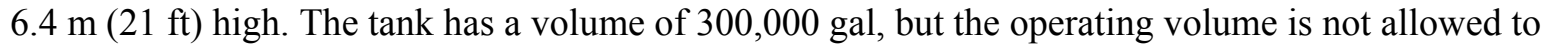
exceed 285,000 gal. The tank is equipped with Type 304L cooling coils. This tank has been filled several times and has contained aluminum and zirconium fuel reprocessing raffinate as well as decontamination waste and SBW. As shown in Figure A-9, Tank WM-188 was emptied in 1993 by calcination of the waste. Since 1993, it has been used to contain ETS bottoms. In 1996, Tank WM-188 was emptied and refilled with waste from the ETS that was considered to contain some high-level waste (HLW). In 1998, it was emptied again, completing processing of all HLW. Since then, the tank has been filled with SBW from the evaporator tank system (ETS) bottoms. Plans for the tank include that it will continue to store concentrated ETS solutions, awaiting final treatment at the Integrated Waste Treatment Unit process.

WM-188

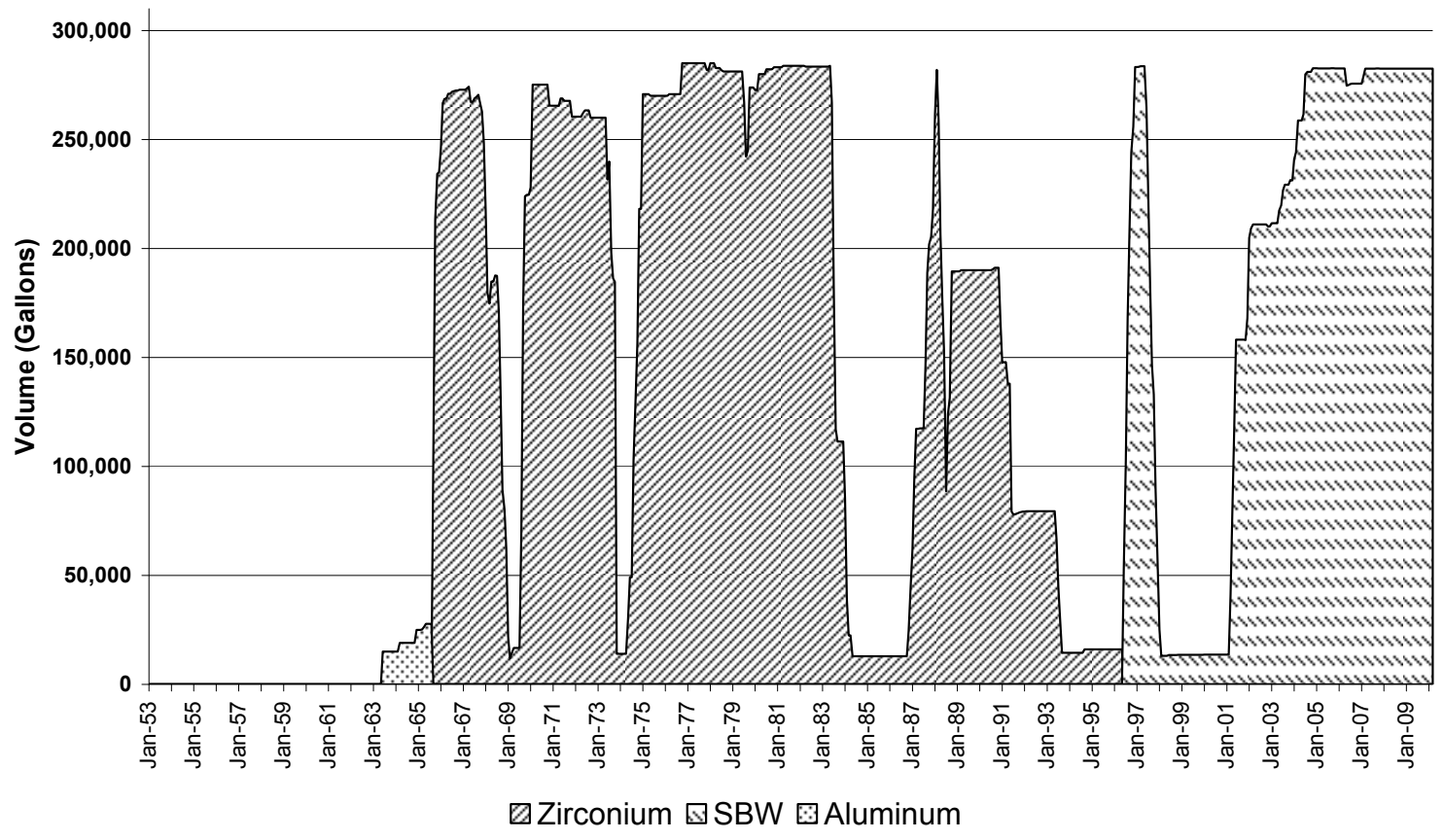

Figure A-9. Historical operation of Tank WM-188. 


\section{Tank WM-189}

Tank WM-189 was put into service in 1966. It is contained in a square reinforced concrete vault. The tank is $15 \mathrm{~m} \mathrm{(50} \mathrm{ft)} \mathrm{in} \mathrm{diameter,} \mathrm{is} \mathrm{constructed} \mathrm{of} \mathrm{304L} \mathrm{stainless} \mathrm{steel,} \mathrm{and} \mathrm{has} \mathrm{a} \mathrm{sidewall} \mathrm{that} \mathrm{is} 6.4 \mathrm{~m}$ $(21 \mathrm{ft}$ ) high. The tank has a nominal volume of 300,000 gal, but the operating volume is not allowed to exceed 285,000 gal. The tank is equipped with Type 304L cooling coils. This tank has been filled several times and has contained zirconium fuel reprocessing raffinate as well as decontamination waste, bottoms from the original High-Level Liquid Waste Evaporator (WC-114) in the Waste Calcining Facility, ETS bottoms, and SBW (Figure A-10). Tank WM-189 was emptied in 1996, and partially refilled with SBW before being emptied again in 2000. Tank WM-189 now contains the SBW bottoms from ETS campaigns. The tank has been characterized, and the waste will await final treatment at the Integrated Waste Treatment Unit process.

WM-189

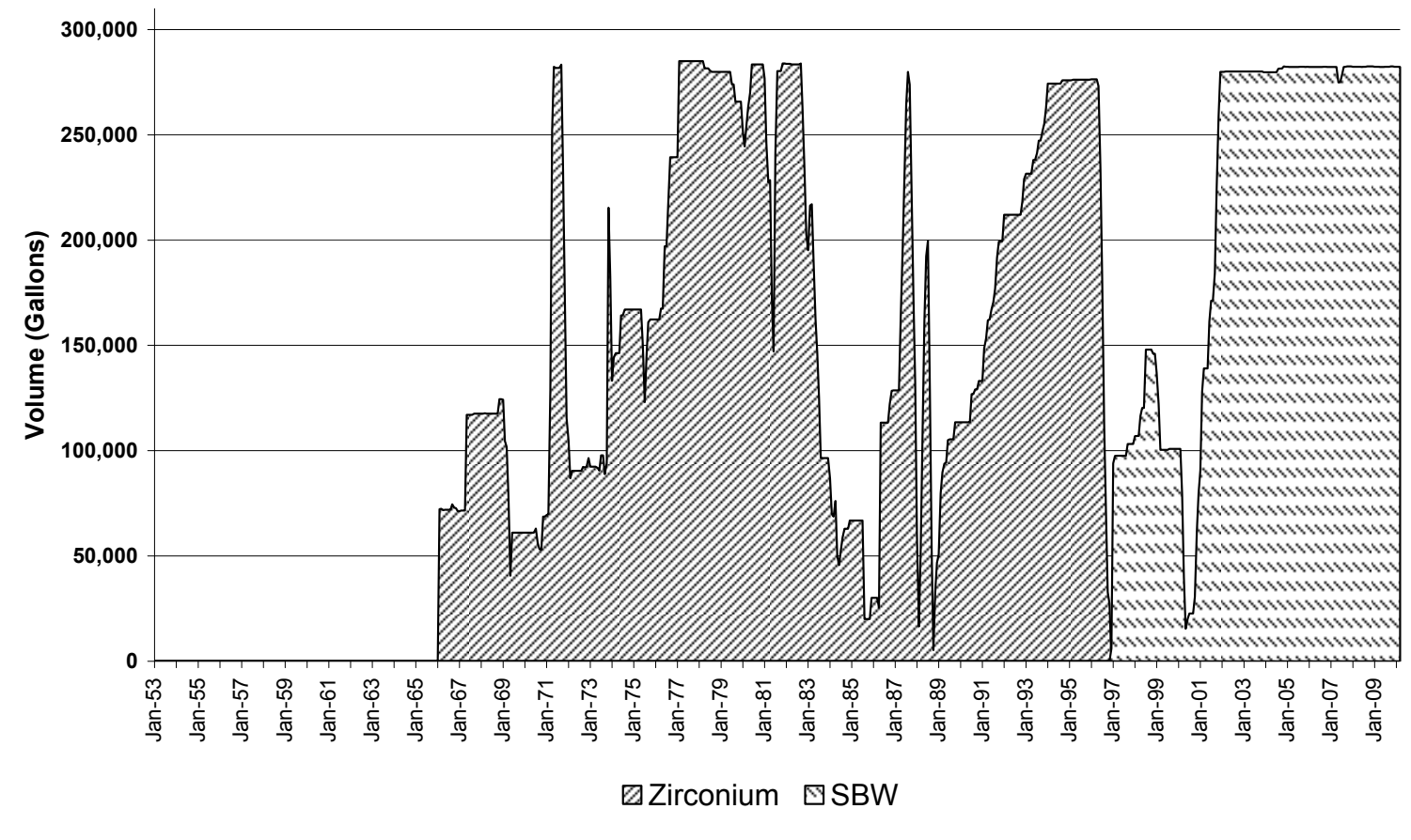

Figure A-10. Historical operation of Tank WM-189. 


\section{Tank WM-190}

Tank WM-190 was never intentionally put into service for the storage of HLW, but was retained as the designated spare tank for use in emergencies. Over many years, about 7,000 gal of accumulated vault sump water and contaminated solution that leaked through closed valves collected in the tank. Most of this waste was removed from the tank in 1982 by use of a temporary waste removal system (see Figure A-11). System modifications and repairs were made to correct the problems, and no subsequent | waste removal has been required. The tank is currently estimated to contain less than 600 gal of solution. The tank is contained in a square reinforced concrete vault. The tank is $15 \mathrm{~m}(50 \mathrm{ft})$ in diameter, is

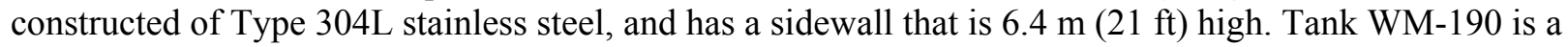
spare tank and would be allowed to fill to a volume of 300,000 gal in case of a leaking tank. The tank is equipped with cooling coils, but this system is out of service and will never be used again.

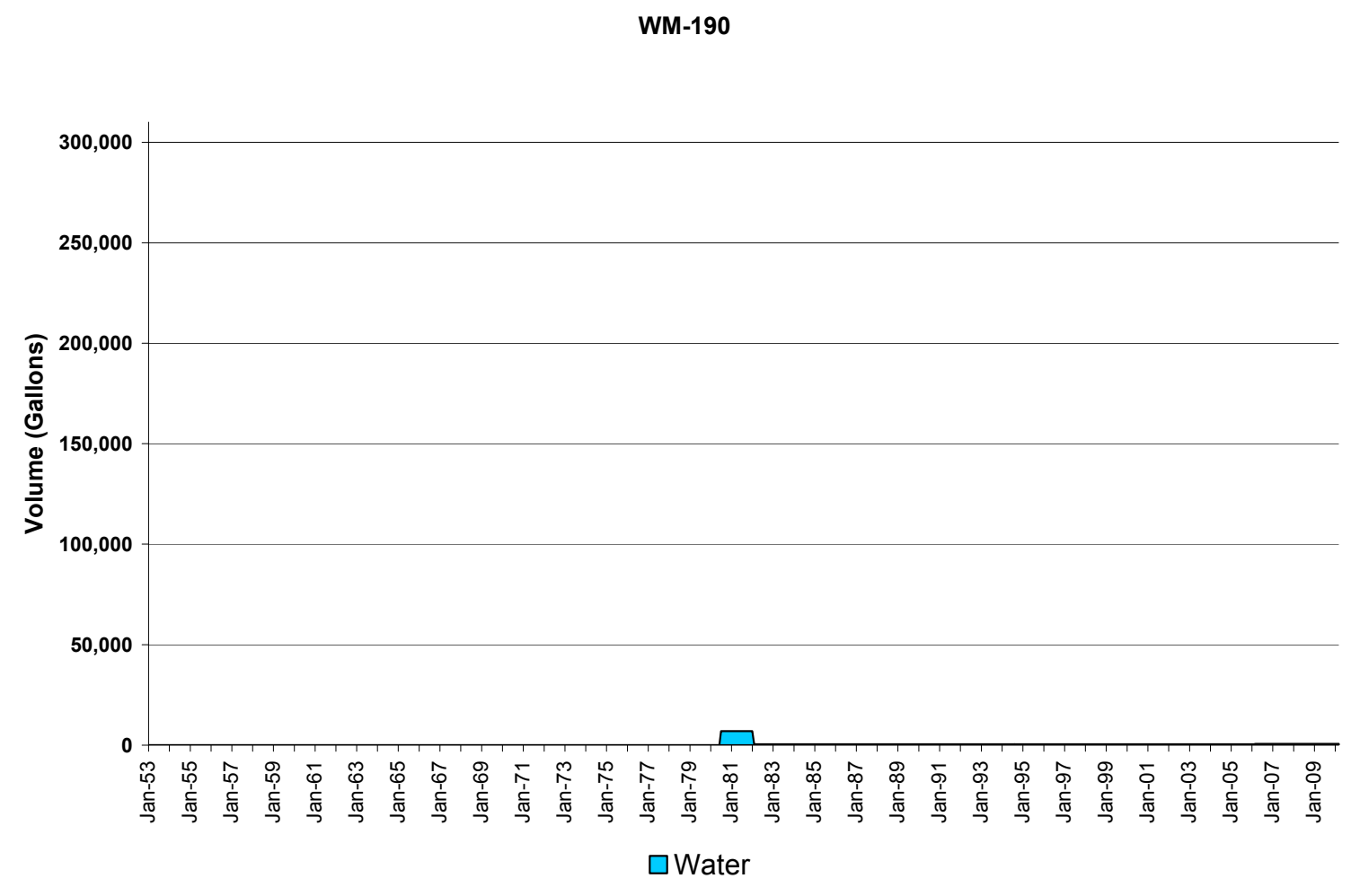

Figure A-11. Historical operation of Tank WM-190. 


\section{REFERENCES}

1. Palmer, W. B., P. A. Anderson, W. J. Dirk, M. D. Staiger, M. C. Swenson, and F. S. Ward, Status and Estimated Life of the 300,000-Gallon INTEC Tanks, INEEL/EXT-99-00743, Rev. 1, Idaho National Engineering and Environmental Laboratory, Lockheed Martin Idaho Technologies Company, Idaho Falls, Idaho, November 1999.

2. Atomic Energy Commission, IDO Liquid Waste Plant CPP 604 Building Operating Equipment Manual, IDO-14079, American Cyanamid Company, Idaho Falls, Idaho, May 22, 1952.

| 3. Latchum, J. W., et al, "Report of the Investigating Committee CPP Waste Tank WM-187 Leakage of March 17, 1962,” La-53-62A, April 17, 1962. 
A-16 


\section{Appendix B}

\section{Degradation Mechanisms}


B-2 


\section{Appendix B}

\section{Degradation Mechanisms}

Several possible aging mechanisms that could affect the 300,000-gal tanks at the Tank Farm Facility (TFF) were identified in the Brookhaven National Laboratory guidelines. ${ }^{1}$ The mechanisms are presented in this appendix followed by a discussion of each mechanism and the degree of significance for the TFF. Appendices $\mathrm{C}$ through $\mathrm{G}$ provide information quantifying degradation.

\section{B1. IDENTIFICATION OF TANK DEGRADATION MECHANISMS}

Stainless steels derive their corrosion resistance from a thin, invisible, surface layer of chromium oxide that is formed during a reaction between the metal and the oxygen present in an ambient air environment or in solution. If mechanically damaged, this layer can spontaneously reform. This thin layer of oxide, which is called the passive layer, is responsible for the improved corrosion resistance of the material as compared to other iron-based alloys such as carbon steel. Stainless steels are not inert to most environments in the way that a noble metal like platinum is because the corrosion resistance depends on the properties of the oxide layer. The passive film may be damaged or broken down at a localized site. Passivity breakdown can occur as a result of straining of the substrate metal, thermal stresses, fluid flow and cavitation, transpassivity polarization, or chemically induced phenomena. ${ }^{2}$

As a tank ages, a variety of aging mechanisms could become operative that will affect leak-tightness or the structural adequacy of the tank. The physical and chemical characteristics of the waste as well as the environment surrounding the tank structure can accelerate the aging process. Several possible aging mechanisms were identified in the Brookhaven guidelines. ${ }^{1}$ These mechanisms are presented in the following sections, followed by a discussion of each mechanism and the degree of significance for the 300,000-gal tanks.

\section{B1.1 General Corrosion}

General, or uniform, corrosion is the constant and continuous loss of material from a surface of the material in contact with a corrosive fluid. For austenitic stainless steel in a nitric acid environment, as in the TFF, the rate of general corrosion should be very low. Nitric acid is often used for passivation of stainless steel, and was in use at the Idaho Nuclear Technology and Engineering Center (INTEC) at the time of construction of the 300,000 -gal tanks. ${ }^{3}$ General corrosion will cause a thinning of the tank wall, but the vessel can still be used until the thinning removes the design corrosion allowance. Although the rate has been very low, general corrosion is, nevertheless, a significant aging mechanism for the tanks.

\section{B1.2 Pitting and Crevice Corrosion}

Pitting corrosion is a common type of localized corrosion in stainless steels. Basically, an electrochemical cell is formed, consisting of a small anodic (corroding) area surrounded by a larger cathodic (noncorroding) surface region that stimulates the localized dissolution at the anode. Once started, pits may continue to grow autocatalytically. Crevice corrosion is associated with geometries where a localized area is occluded, setting up anode-cathode relationships closely related to conditions just described for pitting corrosion. Occluded regions may be found under such things as scales or solids. ${ }^{1}$

While austenitic stainless steels may have very low general corrosion rates, they can pit severely under certain conditions, particularly in the presence of chlorides. The chloride ion, and other halogen ions, can cause local breakdown of passivity on the surface of stainless steels in contact with acid 
solutions. The waste types contained in the 300,000-gal tanks contain chlorides and other halogen ions. However, the presence of nitrate ions in solution has been found to mitigate the onset of pitting. ${ }^{1}$

As pitting proceeds, the concentration of oxygen inside the pit decreases while the concentration of chloride and acid increases. These actions cause an increase in the rate of attack. Local corrosion starting in an occluded region acts in the same way as pitting, with the resulting crevice propagating by the same mechanism. ${ }^{1}$

Because of the halide concentration in TFF waste, pitting and crevice corrosion can potentially be significant corrosion mechanisms despite the nitrate concentration.

\section{B1.3 Concentration Cell and Waterline Corrosion}

Concentration cell corrosion involves localized corrosion attacks on steel where concentration gradients are in contact with the material. Within the waste, the presence of solids against the tank surface can lead to local oxygen concentration cells, or possibly to localized attacking or pitting. Waterline corrosion, a specific type of concentration cell corrosion, results from local differences in $\mathrm{pH}$ at the surface of the waste. Water is continuously evaporating from the surface of the waste and can condense on the inner surface of the tank above the waste level. The condensate can create a concentration cell. Concentration cell corrosion is a potentially significant aging mechanism for the 300,000-gal tanks.

\section{B1.4 Stress-Corrosion Cracking}

Stress-corrosion cracking occurs where a normally ductile metal, like stainless steel, fails in a brittle manner by cracking. The cracks can extend through the wall thickness of a tank and cause leakage. The necessary conditions for this to occur are a susceptible material, tensile stress, minimum threshold temperature, and a particular corrosive environment. These conditions can be met for stainless steels where the corrosive environment contains chloride ion.

Welding causes residual tensile stress, which is sustained unless a stress-relieving treatment is performed on the material. Welding can cause changes in the weld heat-affected zone of susceptible grades of austenitic stainless steels such as Type 304 (0.08\% maximum carbon). The changes are caused by the precipitation of chromium carbides in the heat-affected zone that affect the corrosion performance of the metallic grain boundary area. This effect is termed sensitization and will make the alloy more susceptible to localized corrosion resulting from intergranular attack in some environments. This metallurgically damaged area also is more susceptible to stress-corrosion cracking. The residual tensile stresses in the weld heat-affected zone are enough for stress-corrosion cracking to initiate and propagate; therefore, any stresses from static head are not required.

The low carbon in Types 304L (0.03\% maximum) and 316ELC stainless steels increases the resistance of the TFF material to intergranular corrosion in the as-welded condition. In Type 347 stainless steel, the carbon is preferentially combined with niobium and distributed uniformly through the metal matrix to control intergranular corrosion. To categorically state a minimum required temperature for the initiation of stress-corrosion cracking is difficult, but temperatures of 15 to $20^{\circ} \mathrm{C}$ (59 to $68^{\circ} \mathrm{F}$ ) are probably below the minimum values for stress-corrosion cracking to occur. ${ }^{4}$

As stated in the previous sections, INTEC sodium-bearing waste (SBW) presents an aggressive environment to tank materials. The weight of the liquid in the tanks provides sustained tensile stresses to the tanks as well. Therefore, stress-corrosion cracking is a potential corrosion mechanism for the 300,000-gal tanks. 


\section{B1.5 Microbiologically Induced Corrosion}

Microbiologically induced corrosion is corrosion caused by microbial action. It is more liable to occur in buried tanks or piping, or in tanks in the presence of stagnant water. Both microbiologically induced corrosion and the subsequent localized concentration cell corrosion are unpredictable until they occur. Microbiologically induced corrosion is unlikely to occur in 300,000-gal tanks with the exception of

Tank WM-190, which contains less than 600 gal of water. It is also unlikely to occur in the transfer piping because the piping is sloped to drain.

\section{B2. DEGRADATION MECHANISMS FOR TANK VAULTS}

The degradation mechanisms that may affect the concrete and structural steel that make up the TFF vaults are described in the following sections. These mechanisms have the potential of preventing the vaults from performing their intended functions.

\section{B2.1 Elevated Temperature}

When conventional concrete is exposed to temperatures in the range of 66 to $95^{\circ} \mathrm{C}$, reactions occur involving the loss of absorbed and combined water from the cement paste and possible thermal incompatibilities between the cement paste and the aggregate. The result of this exposure is reduced compressive strength and stiffness of the concrete. For the tank vaults, fuel-reprocessing raffinates that were stored never approached the threshold temperatures for thermal degradation of concrete. The temperature of the waste in storage was limited to $55^{\circ} \mathrm{C}\left(131^{\circ} \mathrm{F}\right)$ for aluminum raffinates. This limit was later reduced to $35^{\circ} \mathrm{C}\left(95^{\circ} \mathrm{F}\right)$. The temperature of the tanks is not known to have exceeded $55^{\circ} \mathrm{C}\left(131^{\circ} \mathrm{F}\right)$. However, the concrete vaults were not exposed to these temperatures because of the air space between the vessels and the vaults and the soil, in contact with the outside of the vaults, provides a heat sink for the concrete. The SBW currently stored in the tanks is much less radioactive than the raffinates that previously were stored in them, and the decay heat produced is low enough that the cooling coils are no longer needed to keep solutions below $35^{\circ} \mathrm{C}\left(95^{\circ} \mathrm{F}\right)$. Therefore, although elevated temperature may be a potentially significant degradation mechanism, it is not likely for the tank vaults.

\section{B2.2 Aggressive Chemical Attack}

Concrete degrades when it is exposed to some chemicals in solution. Strong acids cause degradation because of the high alkalinity of concrete (a pH greater than 12.5). Sulfates, contained in some soils and groundwater, also are potential sources of chemical attack. Such chemical attacks increase the porosity and permeability of the concrete, reduce the alkalinity of the concrete, and subject the concrete to further deterioration that can result in reduced compressive strength and stiffness. Because of the acid nature of the 300,000-gal tank waste solutions, acidic attack of the unlined concrete vaults, in which the tanks are contained, is a potentially significant source of concrete degradation if the waste solution were in contact with a vault for a prolonged period. ${ }^{5,6}$

\section{B2.3 Corrosion of Reinforcing Steel}

Corrosion of reinforcing steel is an aging mechanism similar to acidic corrosion except that the chemical attack is on the reinforcing steel rather than the concrete. In addition, reinforcing steel is susceptible to attack by acid as well as chloride ions in solution. The chloride concentration in TFF SBW waste solutions is sufficiently high to cause corrosion of reinforcing steel. Because of the chloride concentration and the high acid concentration, corrosion of reinforcing steel is a potentially significant 
source of vault degradation if the reinforcing steel becomes exposed to chemicals following degradation of the concrete.

\section{B2.4 Earthquake Damage}

Although not discussed in the Brookhaven guidelines ${ }^{1}$ as a degradation mechanism, earthquakes have the potential of causing significant damage or failure of the TFF vaults. Seismic evaluations are discussed in Section 3.1.8 in the main body of this report.

\section{B3. ANCILLARY EQUIPMENT DEGRADATION MECHANISMS}

The ancillary equipment in the TFF, which is used for the transfer of liquid waste into, out of, and between vessels, is fabricated of Type 300-series stainless steel. The degradation mechanisms discussed for the tanks and vaults relate to the ancillary equipment as well. The applicable mechanisms include general corrosion, pitting and crevice corrosion, stress corrosion cracking for the transfer system, and chemical attack and corrosion of reinforcing steel for the transfer line containment system. Leaks also could develop in the transfer valves as a result of radiation exposure to gasket material, elevated temperatures, lack of cathodic protection, erosion, or wear and fatigue. All leakage would be contained within secondary containment systems and detected by operators. 


\section{B4. REFERENCES}

1. Bandyopadhyay, K., S. Bush, M. Kassir, B. Mather, P. Shewmon, M. Streicher, B. Thompson, D. van Rooyen, and J. Weeks, Guidelines for Development of Structural Integrity Programs for DOE High-Level Waste Storage Tanks, BNL-52527, Brookhaven National Laboratory, Upton, New York, January 1997.

2. Abou-Zeid, K., D. Ellerbrock, T. Haruna, D. Macdonald, E. Sikora, M. Urquidi-Macdonald, A. Wuensche, and L. Zhang, Final Report-Fundamental Studies of Passivity and Passivity Breakdown, DOE/ER/45461 - T2, Pennsylvania State University Center for Advanced Materials, December 1997.

3. Oak Ridge National Laboratory, Idaho Chemical Processing Plant-Heat Treating, Pickling and Passivation Specifications for Stainless Steel Pipe and Vessels, CF-50-10-136, Oak Ridge, Tennessee, October 27, 1950.

4. McIntire, Dale R., Experience Survey Stress Corrosion Cracking of Austenitic Stainless Steels in Water, MTI Publication No. 27, Cortest Laboratories, Cypress, Texas, 1987.

5. Newby, B. J., to V. C. Maio, "Penetration Rate of Fluorinel Waste Into Concrete,” Nby-11-89, March 30, 1989.

6. Brewer, K. N., to G. R. Franz, “Concrete Encased Pipe Compatibility Study,” KNB-09-90, October 18, 1990. 
B-8 


\section{Appendix C}

\section{Corrosion Monitoring}


C-2 


\section{Appendix C}

\section{Corrosion Monitoring}

A history of corrosion monitoring of the 300,000-gal tanks at the Tank Farm Facility (TFF) is provided in this appendix.

The Idaho Nuclear Technology and Engineering Center (INTEC) corrosion-monitoring program was performed using austenitic stainless steel corrosion coupons representative of the materials of construction of the 300,000-gal tanks. At the time of the installation of the corrosion coupons, actual materials used in making the tanks were not available. The coupons were fabricated from available plate, strip, weld consumables, and piping of the same types of material. Correlation between coupon performance and tank performance is inconclusive because although the material and composition of the corrosion coupons was confirmed at the time of their installation, no heat papers ${ }^{\mathrm{b}}$ are available for the initial corrosion coupons or the materials of construction of the TFF tanks. The original corrosion coupon design also did not specifically address the evaluation of crevice corrosion or stress corrosion cracking. Therefore, the possibility of localized corrosion attack in the tanks is not eliminated when corrosion coupons show only general corrosion attack.

Test coupons were initially placed in Tanks WM-180 and WM-181 in the mid-1950s. To establish a long-term surveillance study, corrosion coupons were installed in Tanks WM-182, 183, and 184 in May 1959 and in Tanks WM-185, 186, 187, and 188 in December 1959. ${ }^{1}$ Tank WM-189 received corrosion coupons after construction was completed in $1964 .^{2}$

Corrosion test coupons consisted of seamless and welded hoops, weld tabs, and sections of welded pipe, as shown in Figure C-1, which are held on test jigs, as shown in Figure C-2. These are suspended by stainless steel cables at the 45-, 122-, and 183-cm (18-, 48-, and 72-in.) level above the bottom of the tank. The coupons in Tank WM-180 were suspended on jigs that were built of rod or pipe rather than strap material. Coupons in this tank were oval specimens about $5 \mathrm{~cm}$ (2 in.) in diameter that had been partially flattened to form stressed areas. The test coupons in Tank WM-181 were held on smaller, flat stainless steel clamps. These coupons were clamped flat against the suspension cable. The test coupons were held on small hooks welded to the support assembly. Only a few of these test coupons remained in the tank at the time they were removed. The length of immersion exposure reported for individual coupons from each tank varied depending on the level of waste solution held in each tank during the exposure period.

During the corrosion coupon recovery operations in 1987 and $1988,{ }^{3}$ additional welded corrosion coupons, as shown in Figure C-3, were placed in each of the tanks. These coupons were installed on or near the tank bottom to measure the corrosion occurring in that area. The test assembly was clipped to the bottom of the corrosion coupon cable. During a 1999 video inspection, ${ }^{4}$ the coupons placed in Tank WM-188 were discovered to have gotten caught in the access riser instead of being at the bottom of the tank as intended. Although none of the original coupons or the coupons placed in the tanks during 1987 and 1988 was designed to evaluate localized corrosion, specifically, crevice corrosion stress-corrosion cracking, the coupons placed in the tanks after the most recent coupon retrieval in 2001 were designed to evaluate it. These coupons are described in Section C5.

b. Heat paper, also called a certified materials test report, is documentation from the mill that lists the ingot or ladle chemistry and plate mechanical properties. 


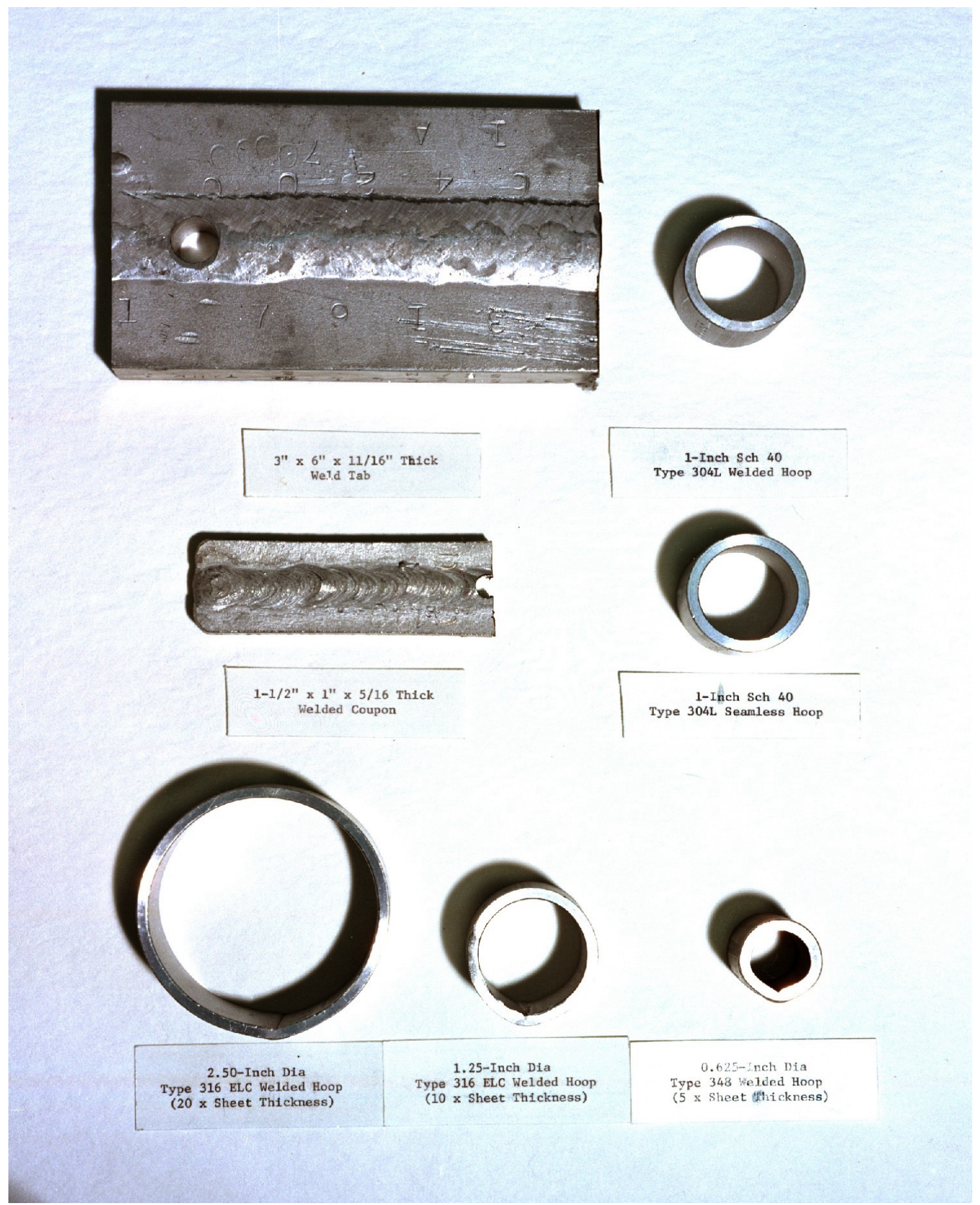

Figure C-1. Types of corrosion coupons exposed in the 300,000-gal tanks (PD03-0029-02). 


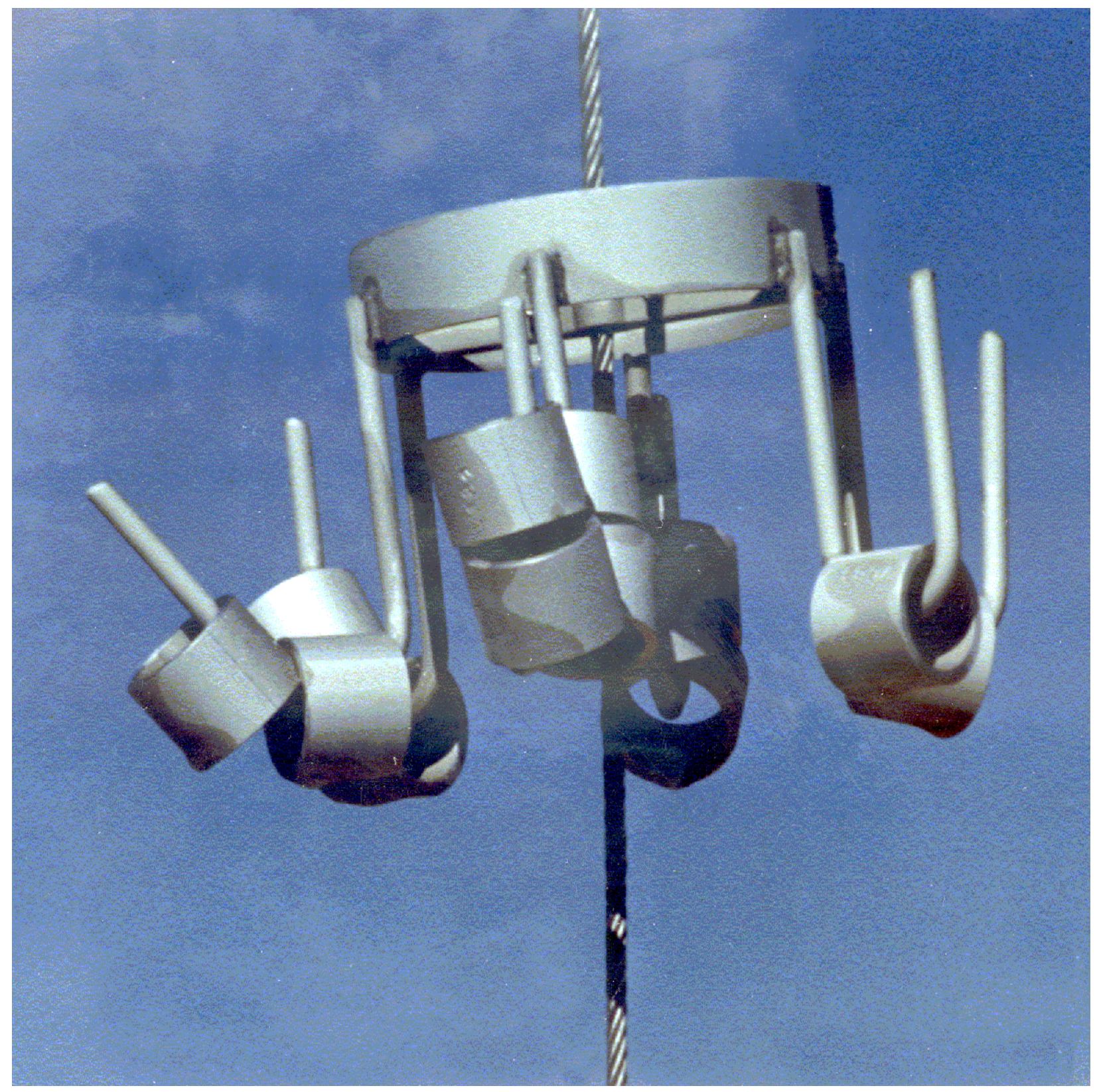

Figure C-2. Typical corrosion specimen test jig used in the 300,000-gal tanks (PD03-0029-03). 


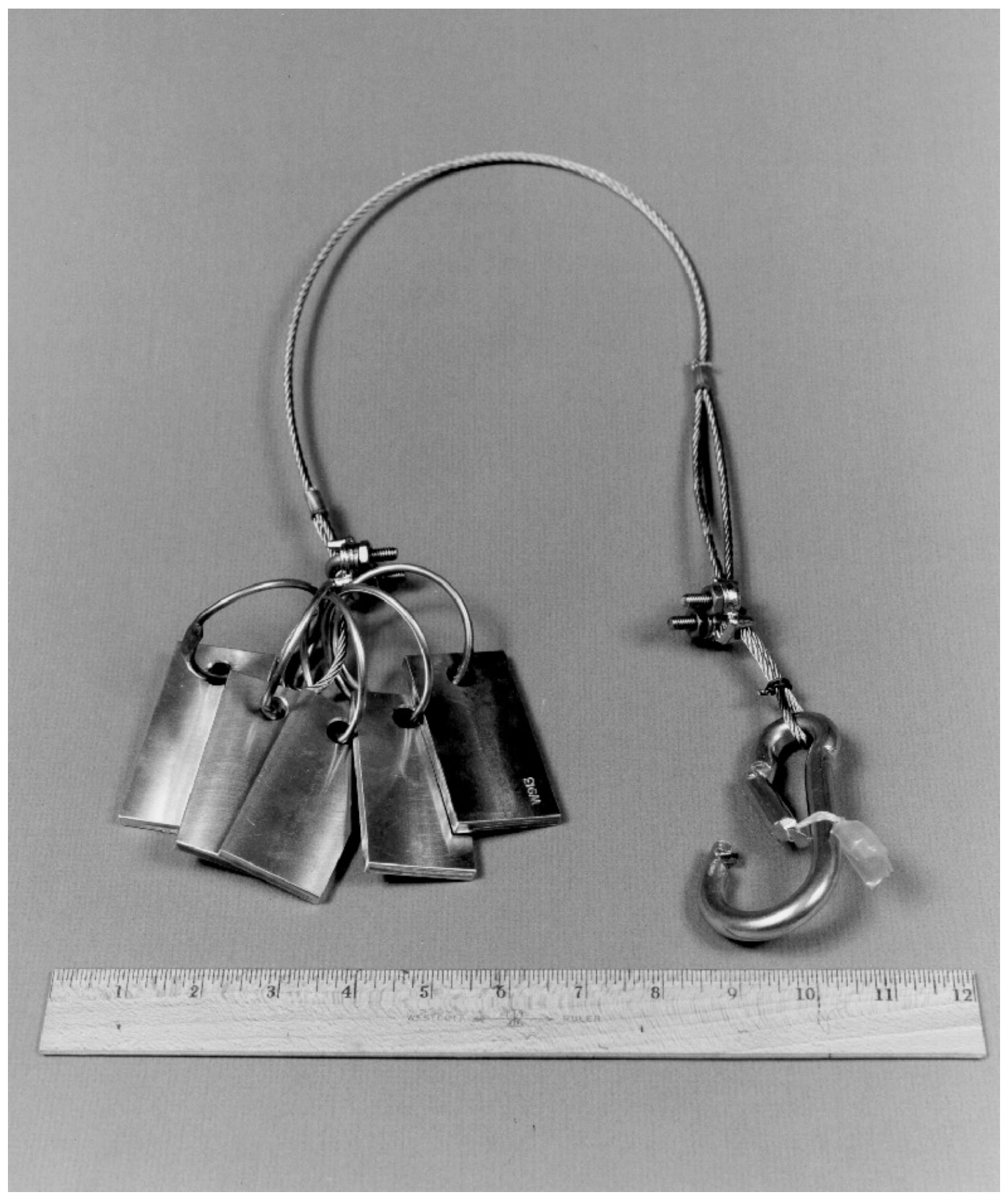

Figure C-3. Corrosion coupon assembly for tank bottom evaluation (PD03-0029-04). 
Under the original long-term corrosion monitoring $\operatorname{plan}^{1}$ for the 300,000-gal tanks, a set of coupons was to be retrieved approximately once every 5 to 10 years. The coupons removed from the tanks are carefully decontaminated to avoid significantly affecting the coupon surfaces relative to their appearances or amounts of surface material that might have corroded away. Blanks or control coupons accompany actual tank coupons through the decontamination process so that any corrosive effects from the decontamination can be recognized and given appropriate consideration in the interpretation of the results. The corrosion data are evaluated and the results reported. These data provide an important part of the technical basis from which tank lives can be estimated. The corrosion coupons were removed from WM-180, WM-181, WM-184, WM-185, and WM-186 at the time of tank washing, and were placed in storage without decontamination or examination. The tanks have been RCRA closed and these coupons will probably be discarded unless funds are identified for evaluation.

\section{C1. RESULTS OF CORROSION COUPON RETRIEVALS FROM 1962 TO 1983}

In 1962, corrosion studies were conducted on welded stainless steel Type 347 and unwelded Type 304L in different waste solutions resulting from the reprocessing of nuclear fuels at INTEC. Corrosion rates for Tanks WM-180, WM-182, WM-183, WM-184, WM-185, and WM-187 were determined by immersing test specimens of the various stainless steels in the actual waste tanks for periods up to 7 years. Maximum rates of 0.1 mil per year were observed on 304L and 347 specimens that had been exposed to acidic or acid-deficient aluminum process first-cycle raffinates at about $25^{\circ} \mathrm{C}$. No localized corrosion attack was evident. Specimens of 304L exposed to the acid-deficient aluminum nitrate raffinate from the second and third cycles showed maximum rates of 0.07 mil per year at about $25^{\circ} \mathrm{C}$ $\left(77^{\circ} \mathrm{F}\right)$ with shallow pits 5 mils deep indicating evidence of minor localized attack. Most of the machine markings had corroded away. ${ }^{1}$

In 1976, maximum rates of 0.1 mil per year were observed on Types 304L and 347 stainless steel specimens in the as-welded metallurgical condition, which had been exposed to aluminum-zirconium process first-cycle waste at about $25^{\circ} \mathrm{C}$. No localized attack was evident. Specimens of Types 304L and 347 stainless steels exposed to the second- and third-cycle raffinates showed maximum rates of 0.006 mil per year with evidence of only minor localized attack, and no pitting as identified in $1962 .^{2}$

The 1983 report indicated that the highest corrosion rate measured was 0.059 mil per year on samples exposed to principally aluminum-zirconium first-cycle waste. The mean corrosion rate for the tanks in service was 0.014 mil per year. No localized corrosion attack was evident on any of the coupons. ${ }^{5}$

\section{C2. RESULTS FROM THE 1988 CORROSION COUPON RETRIEVAL}

The results from the 1988 corrosion coupon evaluation indicate that the general corrosion rates of test coupons recovered from the TFF tanks are not excessive. ${ }^{3}$ The highest corrosion rates were sustained in the tanks used for storage of zirconium first-cycle raffinates. Corrosion coupons from the three tanks that were used for this service, WM-187, WM-188, and WM-189, showed average corrosion rates of $7.9 \times 10^{-3}$ to $5.3 \times 10^{-2}$ mils per year. Calculations based on the maximum observed general corrosion rate that was on coupons from Tank WM-188 indicated a maximum metal loss from the internal surfaces of 1.2 mils over the tank's service life of 23.3 years up to 1988 . The design corrosion allowance for the tank is $125 \mathrm{mils}$; however the corrosion allowance was reduced to $50 \mathrm{mils}(0.050 \mathrm{in}$.) after a seismic study in $1993 .{ }^{6}$

The corrosion coupons that were immersed in the nonzirconium first-cycle waste in Tank WM-182 showed an average general corrosion rate of $1.3 \times 10^{-2}$ mils per year, with a maximum rate of 
$1.4 \times 10^{-2}$ mils per year. ${ }^{3}$ Calculations using the maximum corrosion rate indicated a metal loss from the internal surfaces of the vessel of 0.46 mils over the 32.9 years of tank service to 1988 .

Corrosion in sodium-bearing waste (SBW) was significantly less than that observed for first-cycle waste during the 1988 inspections. The average general corrosion rate for test coupons from tanks containing SBW, Tanks WM-180, WM-183, WM-184, and WM-186, was $6.6 \times 10^{-4}$ mils per year. The maximum corrosion rate observed in any of the four tanks was $3.4 \times 10^{-3}$ mils per year for a test coupon at the 45-cm (18-in.) level in Tank WM-186. Based on that corrosion rate and the 25.8-year service life of Tank WM-186 up to 1988 , the metal loss from the internal surfaces of the tank caused by general corrosion would be 0.088 mil. $^{3}$ Physical examination of the corrosion coupons did not reveal any significant localized corrosion attack. ${ }^{3}$

\section{C3. RESULTS FROM 1999 CORROSION COUPON RETRIEVAL}

In 1999, coupons from Tanks WM-182 and WM-183 were recovered for examination. The coupon retrieval activities for Tank WM-182 revealed that the support jigs, including the new assembly for corrosion coupons that was added in 1988 to monitor the tank bottoms condition, were in place as expected. The cable and jig appeared to be in excellent condition with no observed localized corrosion. Only a white deposit was observed on the support cable, coupons, and coupon support jigs. ${ }^{7}$

Because Tank WM-182 was being taken out of service for closure all of the remaining 45 coupons were recovered, including five from the tank bottom, 14 from the $45-\mathrm{cm}$ (18-in.) level above the bottom, 21 from the 122-cm (48-in.) level above the bottom, ${ }^{c}$ and five from the $183-\mathrm{cm}$ (72-in.) level above the bottom. The coupon sets retrieved from each of the four levels are shown in Figures C-4 through C-7. ${ }^{7}$

The highest average corrosion rate for a set of coupons retrieved from Tank WM-182 exposed at any level in the tank was $1.2 \times 10^{-2}$ mils per year at the $183-\mathrm{cm}(72-$ in.) level. At that rate, metal loss calculates to 0.51 mil from the internal surfaces of the vessel over the 44.4 years of service to 1999 . The maximum corrosion rate observed for any single coupon from the tank was $1.24 \times 10^{-2}$ mils per year, which calculates to a metal loss of 0.55 mil over the 44.4 years of service to $1999 .^{7}$

Visual examination of the seamless pipe corrosion coupons from Tank WM-182 under a binocular microscope at $20 \times$ magnification revealed minor localized corrosion in the form of end-grain attack on the ends of the coupons (i.e., the cut edges). End-grain attack would not normally be seen during tank

c. The coupons reportedly ${ }^{7}$ were placed at the 36 -in. level; however, laboratory notebooks indicate that the coupons were placed at the 48-in. level. 


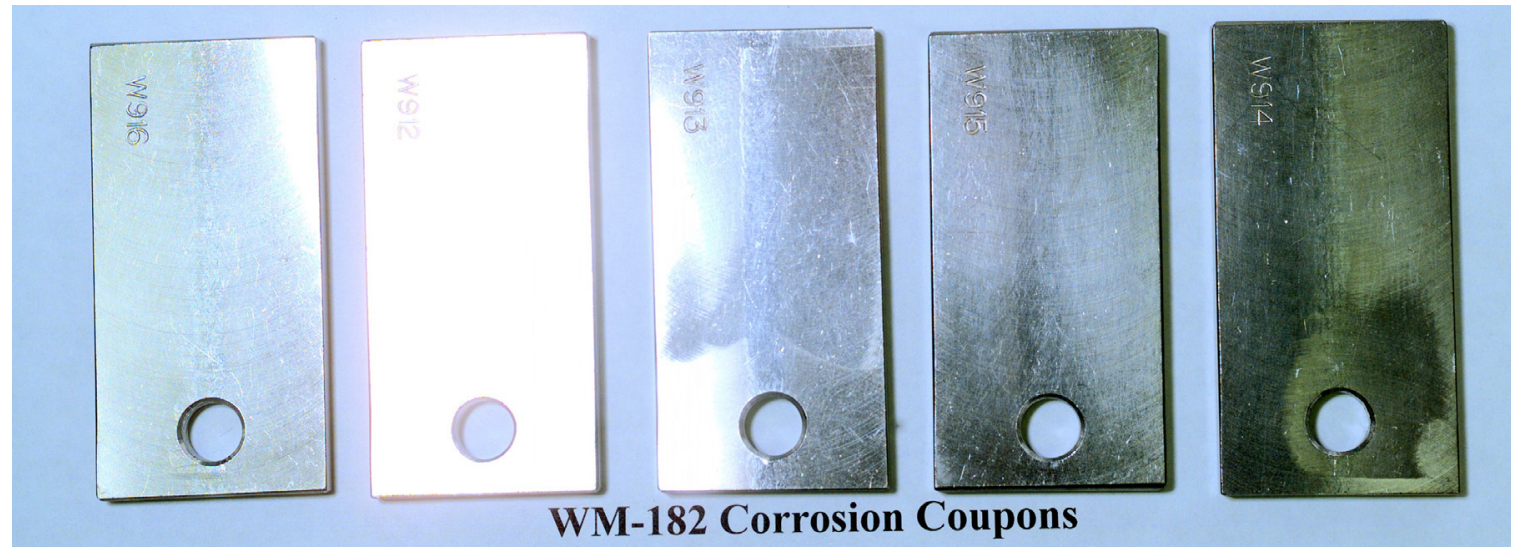

Figure C-4. Tank WM-182 coupons at the 0-in. level after 11.4 years of exposure (PD01-0406-17).

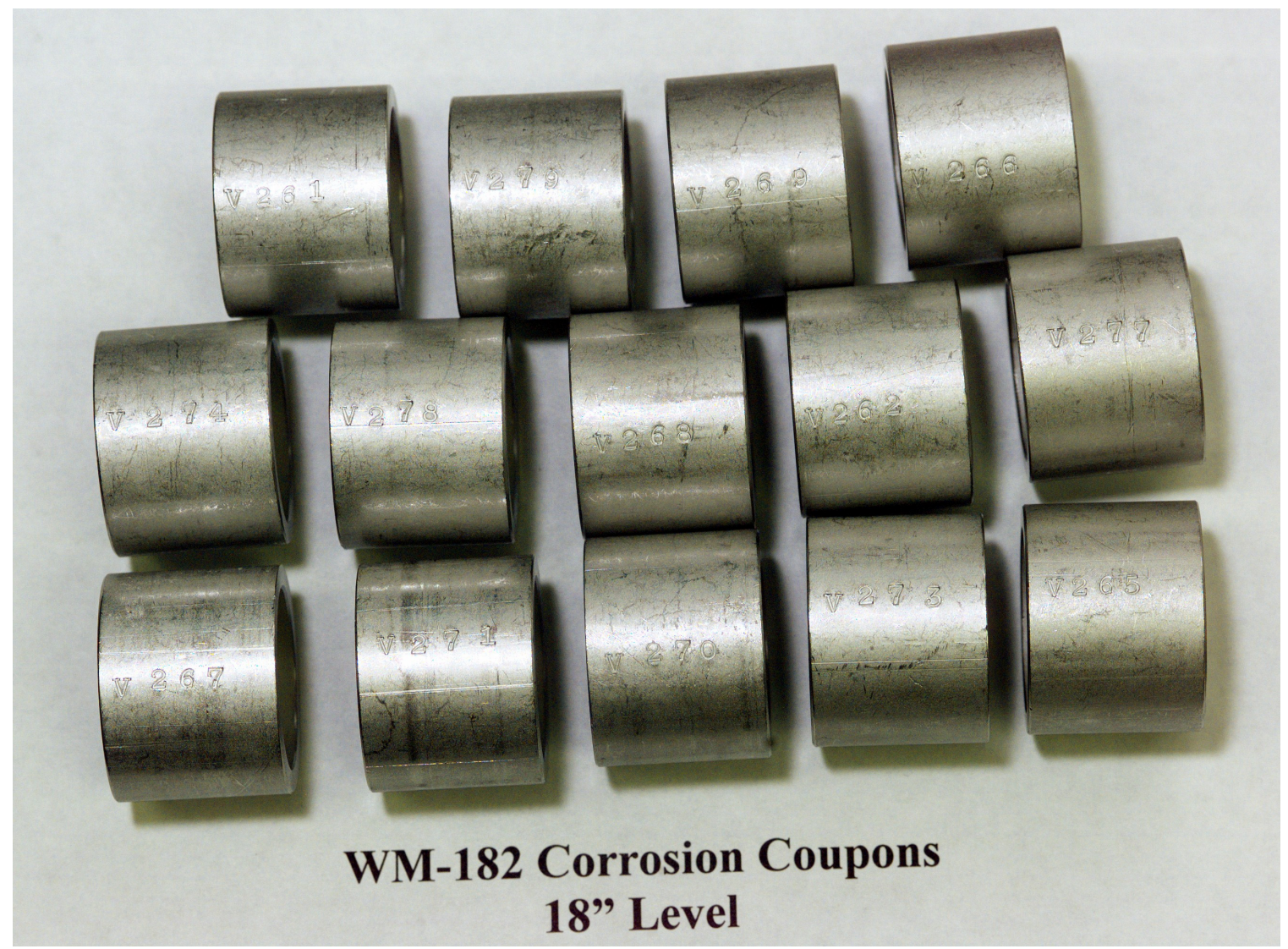

Figure C-5. Tank WM-182 coupons at the 45-cm (18-in.) level after 30.5 years of exposure (PD01-0406-9). 


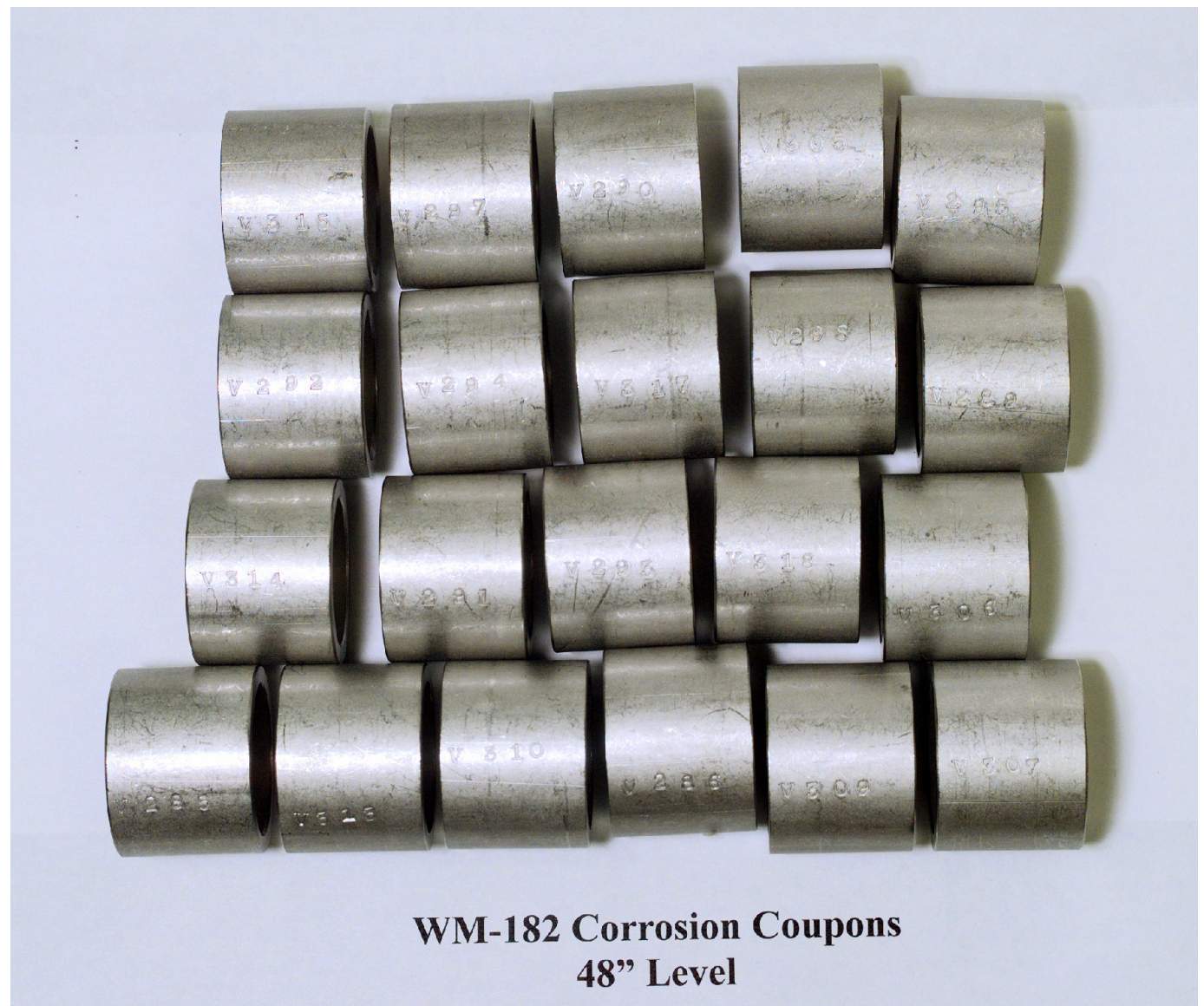

Figure C-6. Tank WM-182 coupons at the 122-cm (48-in.) level after 28.3 years of exposure (PD01-0406-8). 


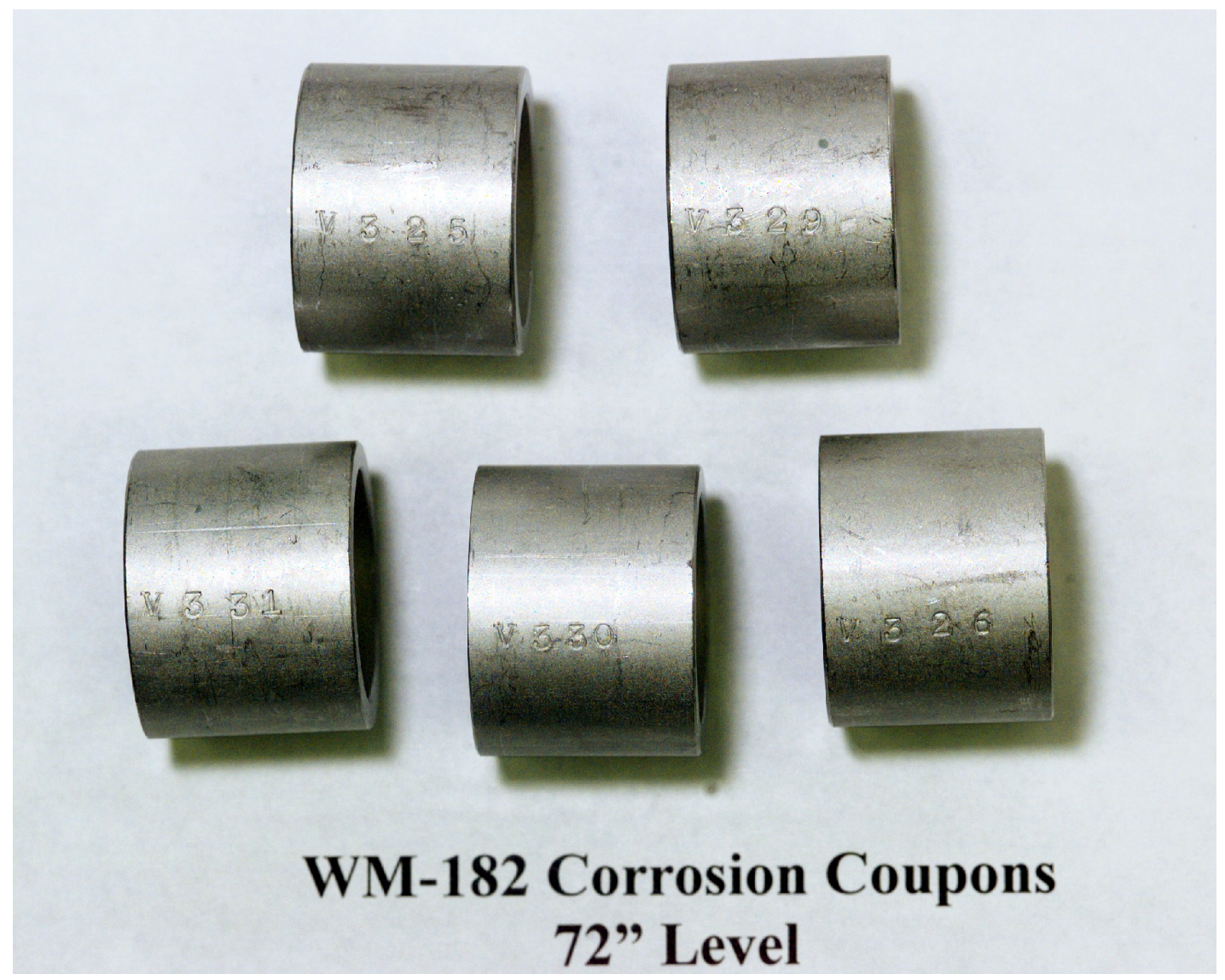

Figure C-7. Tank WM-182 coupons at the 183-cm (72-in.) level after 26.5 years of exposure (PD01-0406-10).

construction, which involves welding together and situating of metal plates so that the end grains are not exposed to the contents of the tank. Very slight pit initiation parallel to the extrusion marks on the surface of the seamless pipe coupons also was shown. Because fabrication of the plate used for tank construction is similar to that for the coupons, similar attack could have occurred in the vessel. ${ }^{7}$

The coupon retrieval activities for Tank WM-183 revealed that the support jigs, including the new assembly for corrosion coupons that was added in 1988 to monitor the tank bottoms condition, were in place as expected. A dark deposit was observed on the support cable, coupons, and coupon support jigs. The cable and coupon support jigs were not decontaminated and examined during this inspection. ${ }^{8}$

Because Tank WM-183 was also being taken out of service, all of the remaining 44 coupons were retrieved including five from the tank bottom, 17 from the $45-\mathrm{cm}$ (18-in.) level above the bottom, nine from the 122-cm (48-in.) level above the bottom, and 13 from the 183-cm (72-in.) level above the bottom. ${ }^{8}$ The coupon sets retrieved from each of the four levels are shown in Figures C-8 through C- 11.

Eleven of the coupons from Tank WM-183 were photographed under the microscope at magnifications ranging from $50 \times$ to $60 \times$. Eight of the photographed coupons were then examined under an optical interferometer to measure pit and linear indication depths. Some of the photographs and associated interferometer scans are shown in Figures C-12 through C-15. One of the coupons from the 45-cm (18-in.) level, Coupon V-349, was sectioned to examine a linear indication. No cracking was indicated in the sectioned sample. Small pits and the linear indication are shown in Figures C-16 through C-18. 

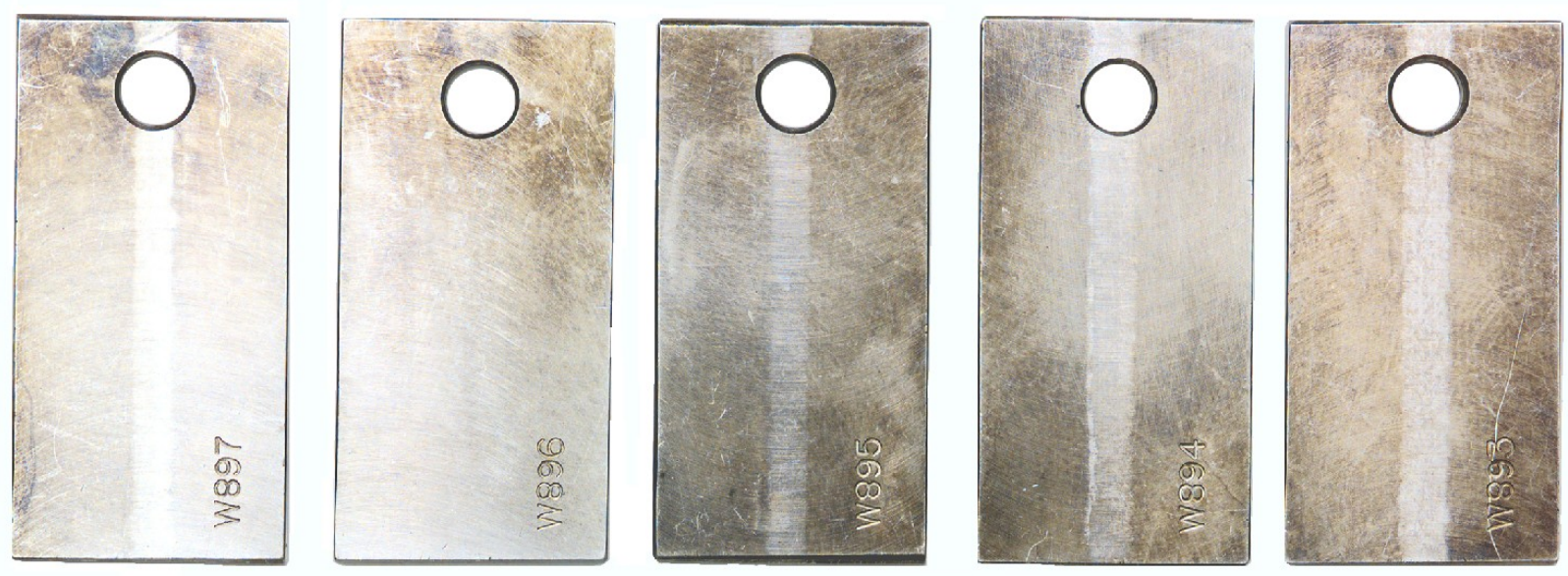

\section{WM-183 (BOTTOMS) \\ TYPE 304L SS - 11.5 Yr EXPOSURE}

Figure C-8. Tank WM-183 coupons at the 0 -in. level after 11.5 years of exposure (PD01-0066-25). ${ }^{8}$
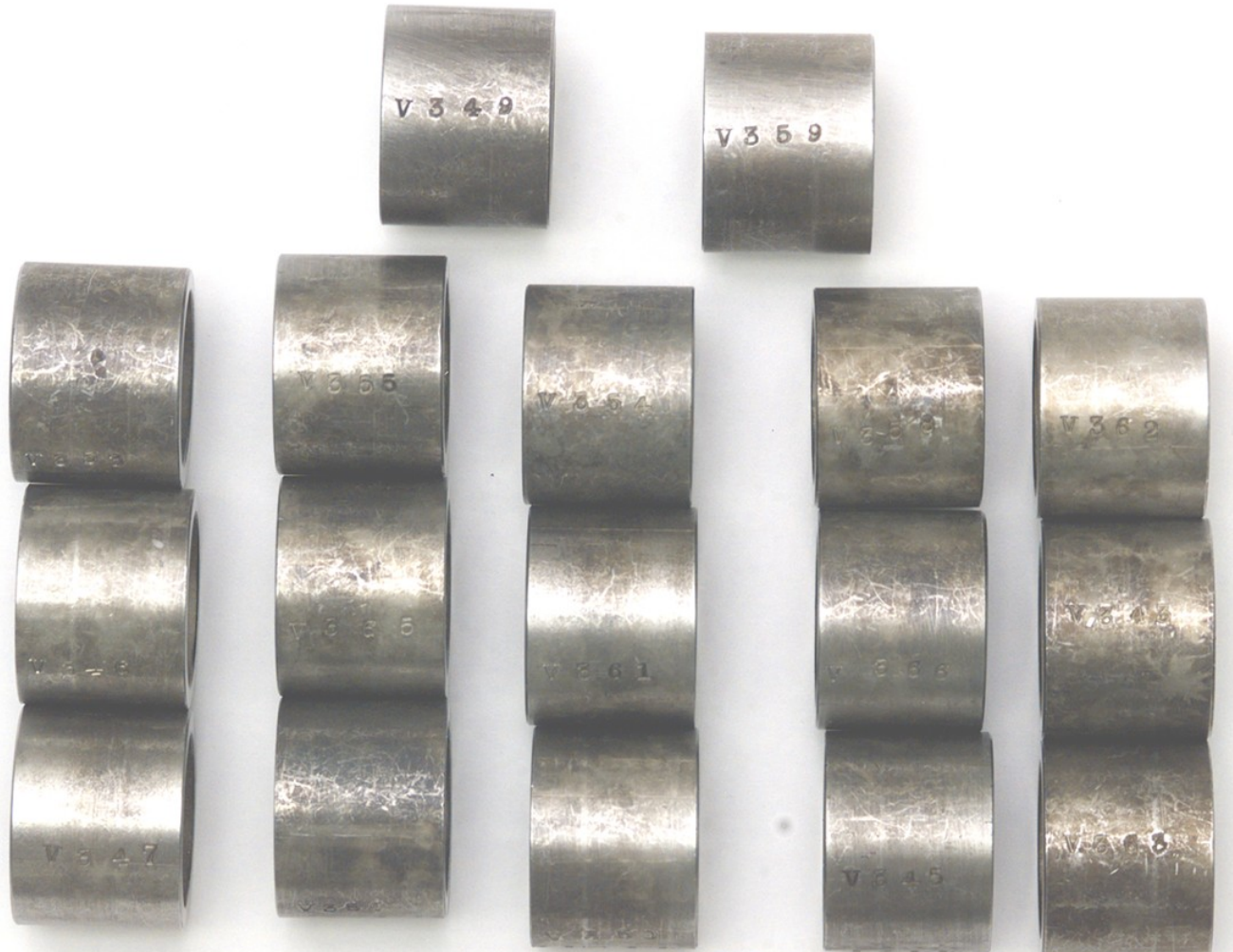

\section{WM-183 (18 IN LEVEL) - TYPE 304L SS \\ 38.5 YEARS EXPOSURE}

Figure C-9. Tank WM-183 coupons at the 45-cm (18-in.) level after 38.5 years of exposure (PD01-0066-31). ${ }^{8}$ 


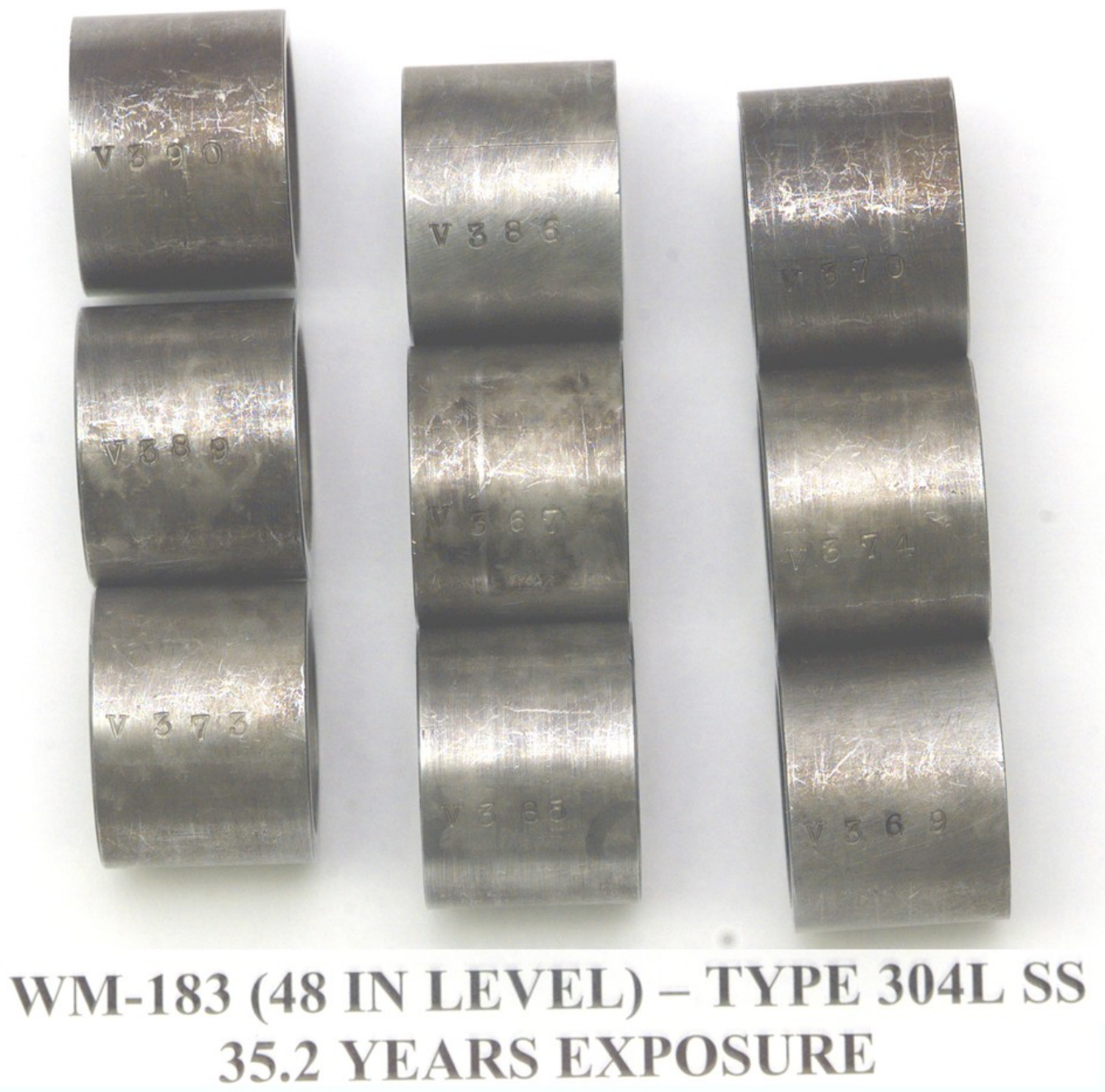

Figure C-10. Tank WM-183 coupons at the 122-cm (48-in.) level after 35.2 years of exposure (PD01-0066-01). ${ }^{8}$ 

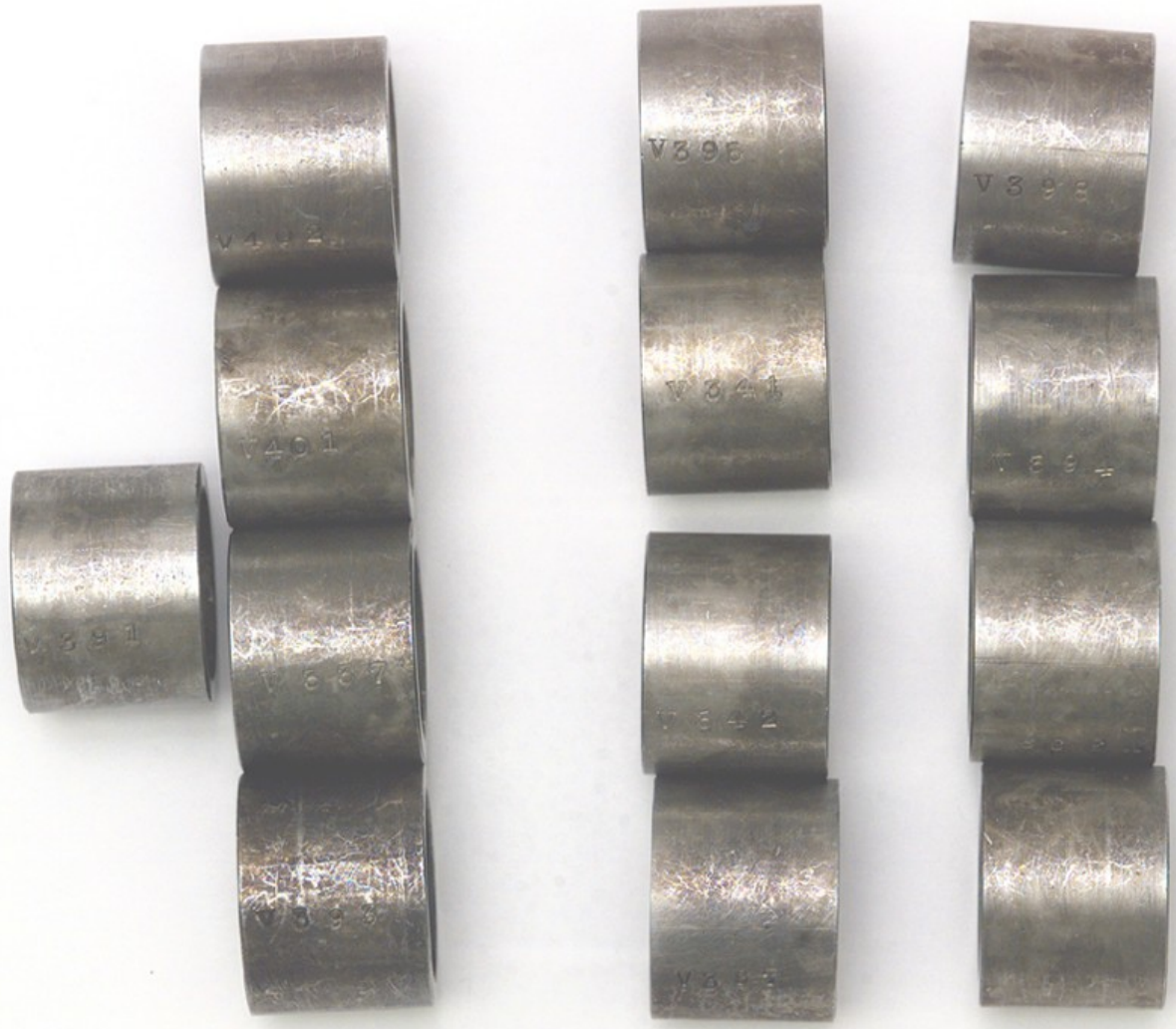

\section{WM-183 (72 IN LEVEL) - TYPE 304L SS 33.7 YEARS EXPOSURE}

Figure C-11. Tank WM-183 coupons at the 183-cm (72-in.) level after 33.7 years of exposure (PD01-0066-11). ${ }^{8}$ 


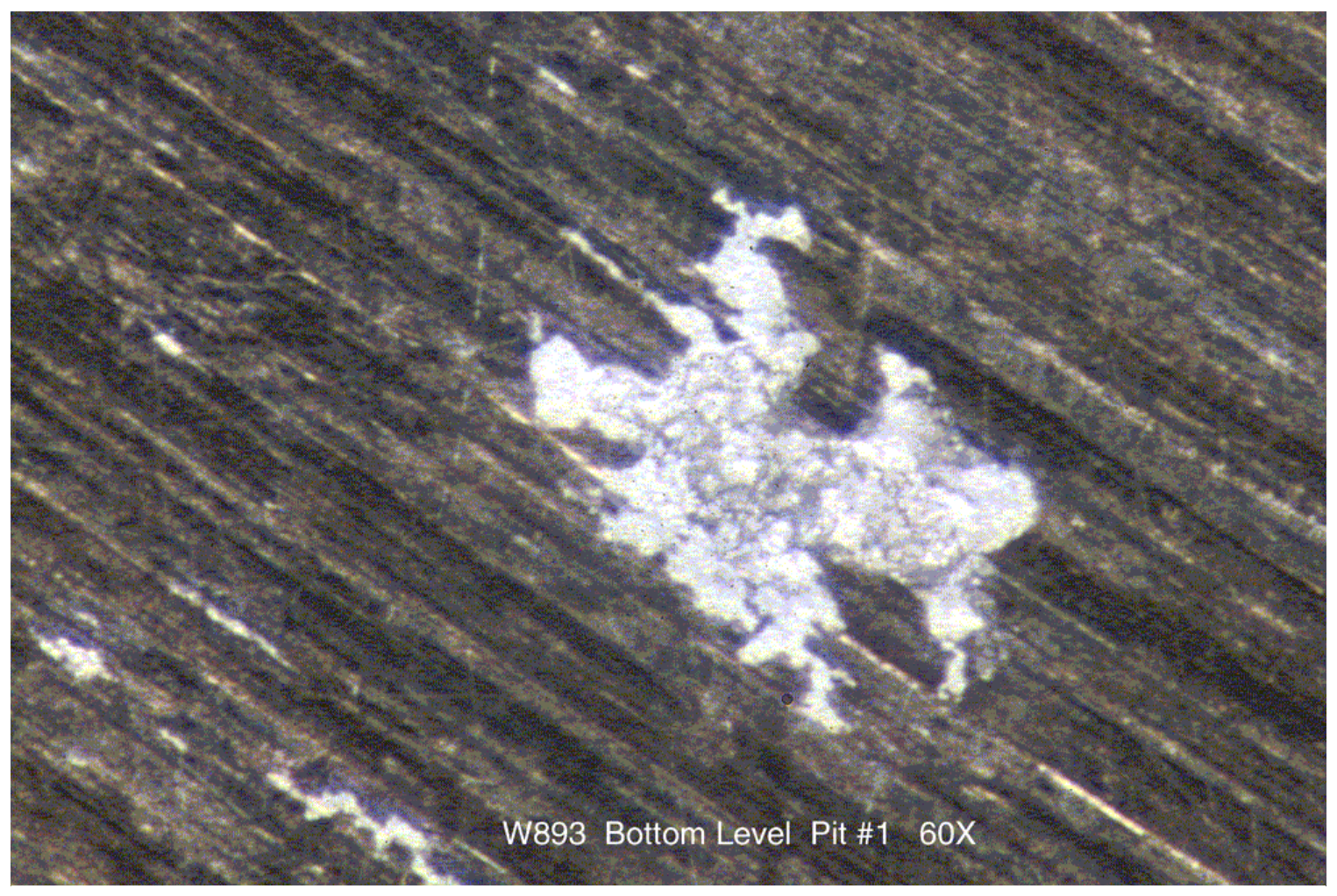

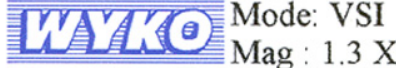

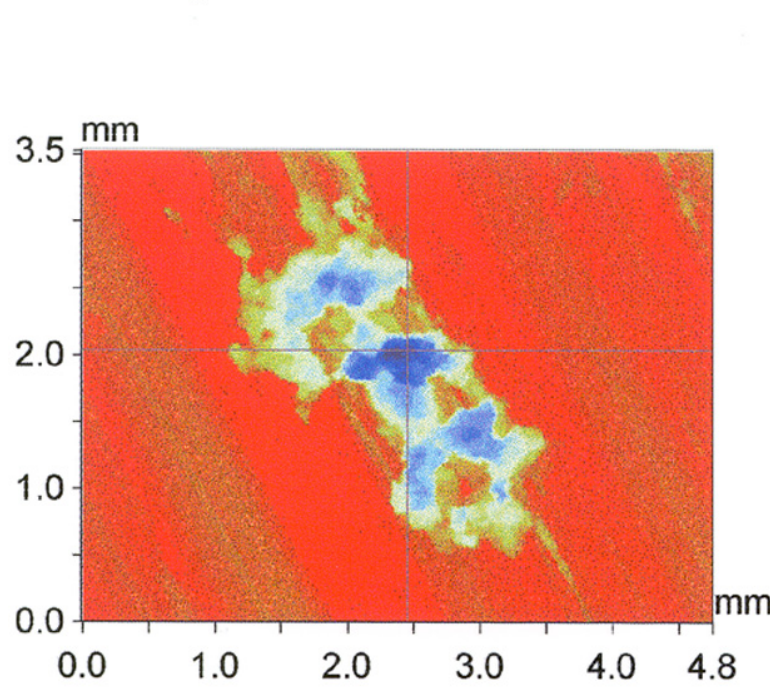

Size: $736 \times 471$
2D Profiles X-Profile / 2 Pt / Radial

$02 / 06 / 01$

07:35:54
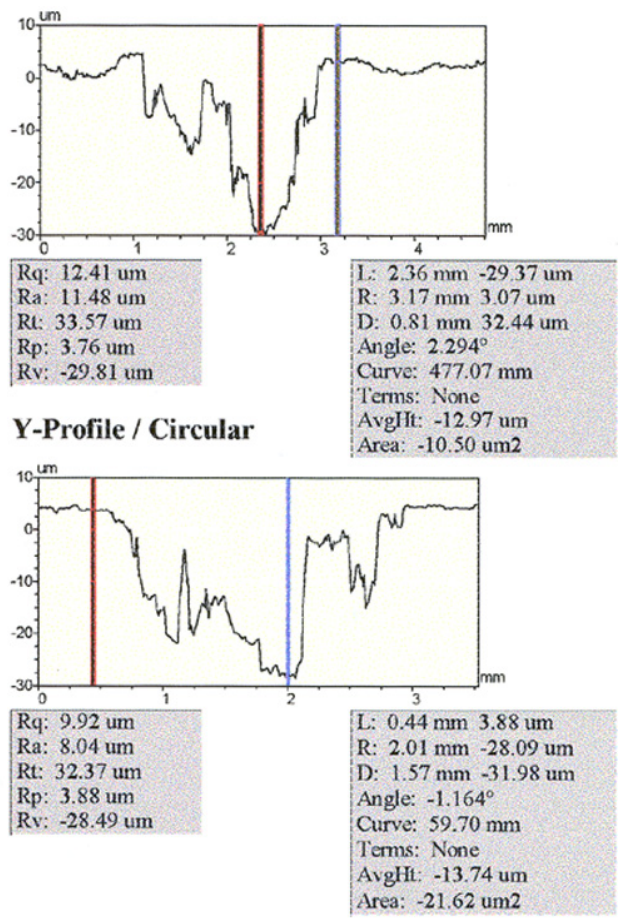

Title: W893 Edge Pit \#1

Note: Bottom Level WM-183 Coupon

Figure C-12. Magnification and interferometer scan of Pit \#1 on Coupon W893 at the 0 -in. level in Tank WM-183 (PD01-0066-52 and PD03-0029-15). ${ }^{8}$ 


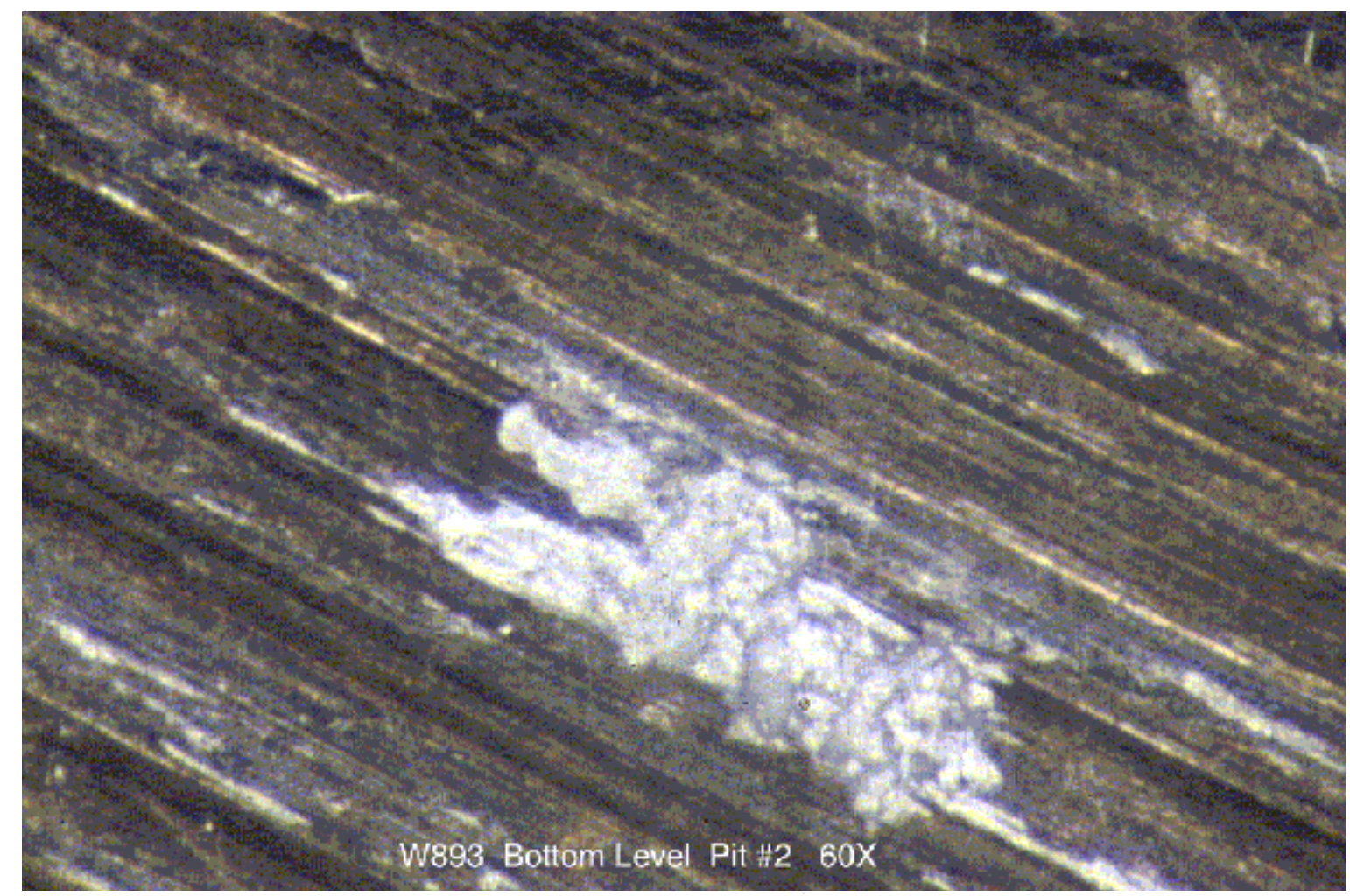

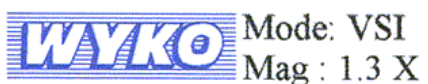

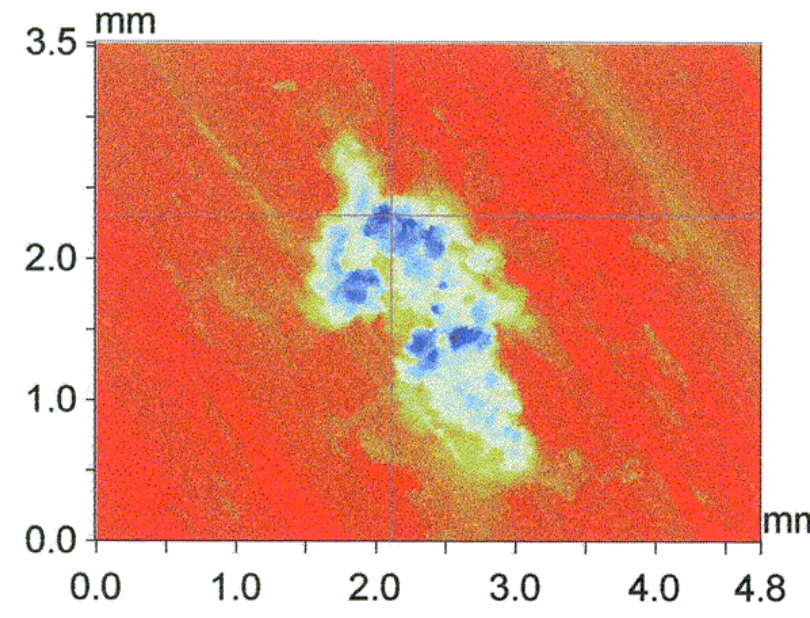

Size: $736 \times 471$
2D Profiles x-Profile / 2 Pt / Radial

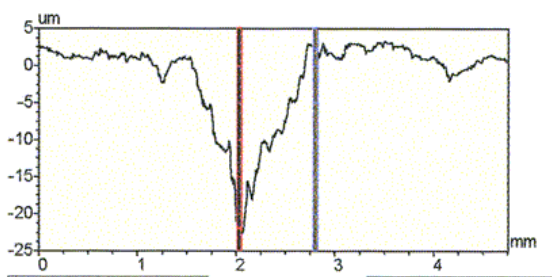

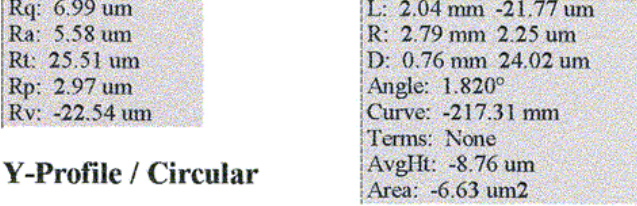

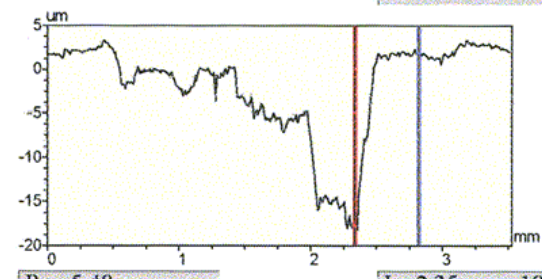

L: $2.35 \mathrm{~mm}-18.05 \mathrm{um}$

R: $2.82 \mathrm{~mm} 1.91 \mathrm{um}$

D: $0.47 \mathrm{~mm} 19.96 \mathrm{um}$ Angle: $2.407^{\circ}$

Curve: $-2.68 \mathrm{~mm}$

Terms: None

AvgHt: -1.34 um Area: $-0.64 \mathrm{um} 2$

\section{Note: Bottom Level WM-183 Coupon}

Figure C-13. Magnification and interferometer scan of Pit \#2 on Coupon W893 at the 0 -in. level in Tank WM-183 (PD01-0066-53 and PD03-0029-16). ${ }^{8}$ 


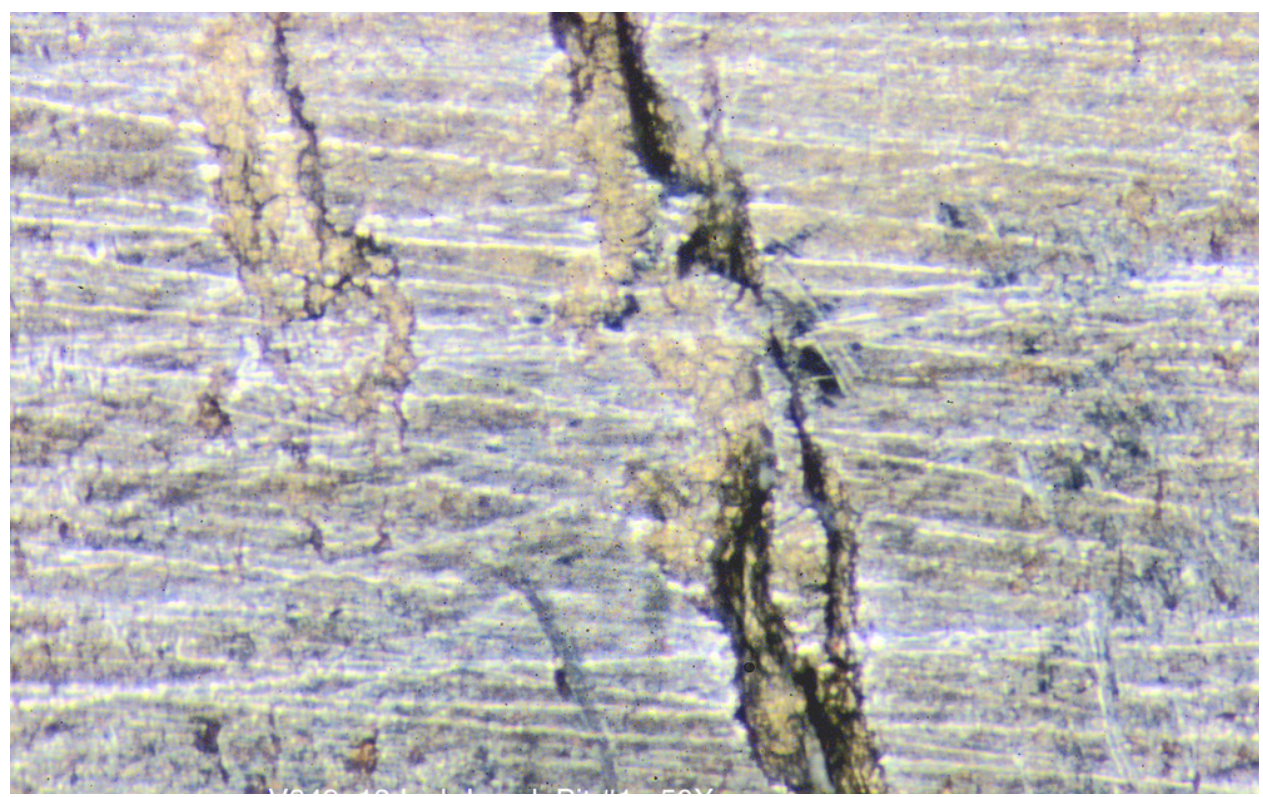

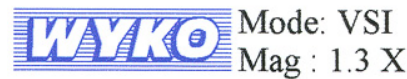

2D Profiles X-Profile / 2 Pt / Radial

$02 / 06 / 01$

$08: 33: 13$
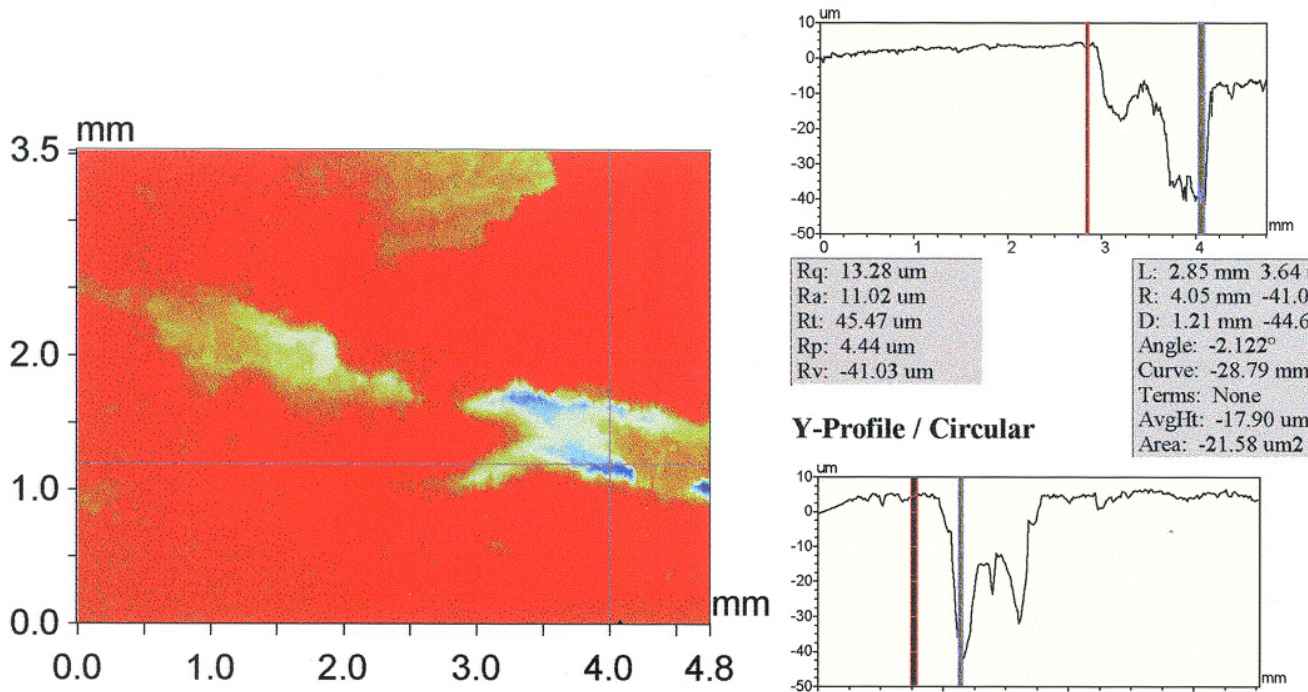

Rq: $13.28 \mathrm{um} \quad$ L: $2.85 \mathrm{~mm} 3.64 \mathrm{um}$

Ra: $11.02 \mathrm{um} \quad$ R: $4.05 \mathrm{~mm}-41.03 \mathrm{um}$

Rt: $45.47 \mathrm{um} \quad$ D: $1.21 \mathrm{~mm}-44.68 \mathrm{um}$

Rp: 4.44 um

Rv: -41.03 um

D: $1.21 \mathrm{~mm}$

Y-Profile / Circular AvgHt: -17.90 um

Curve. $-28.79 \mathrm{~mm}$

Terms: None

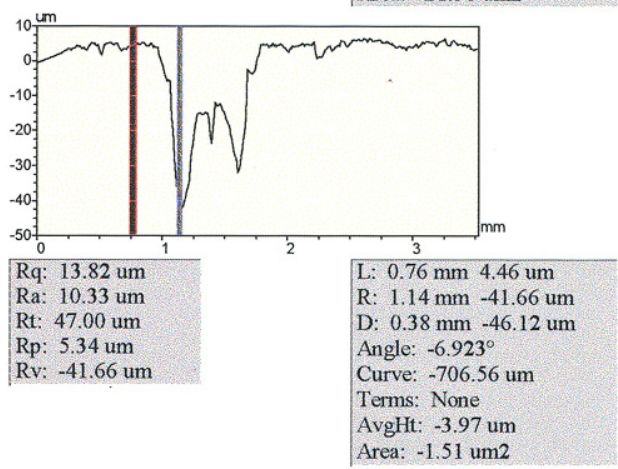

Title: V349

Note: 18" Level WM-183 Coupons

Size: $736 \times 471$

Area: -1.51 um

Figure C-14. Magnification $(50 \times)$ and interferometer scan of linear indication on Coupon V349 at the 45-cm (18-in.) level in Tank WM-183 (PD01-0066-55 and PD03-0029-17). ${ }^{8}$ 

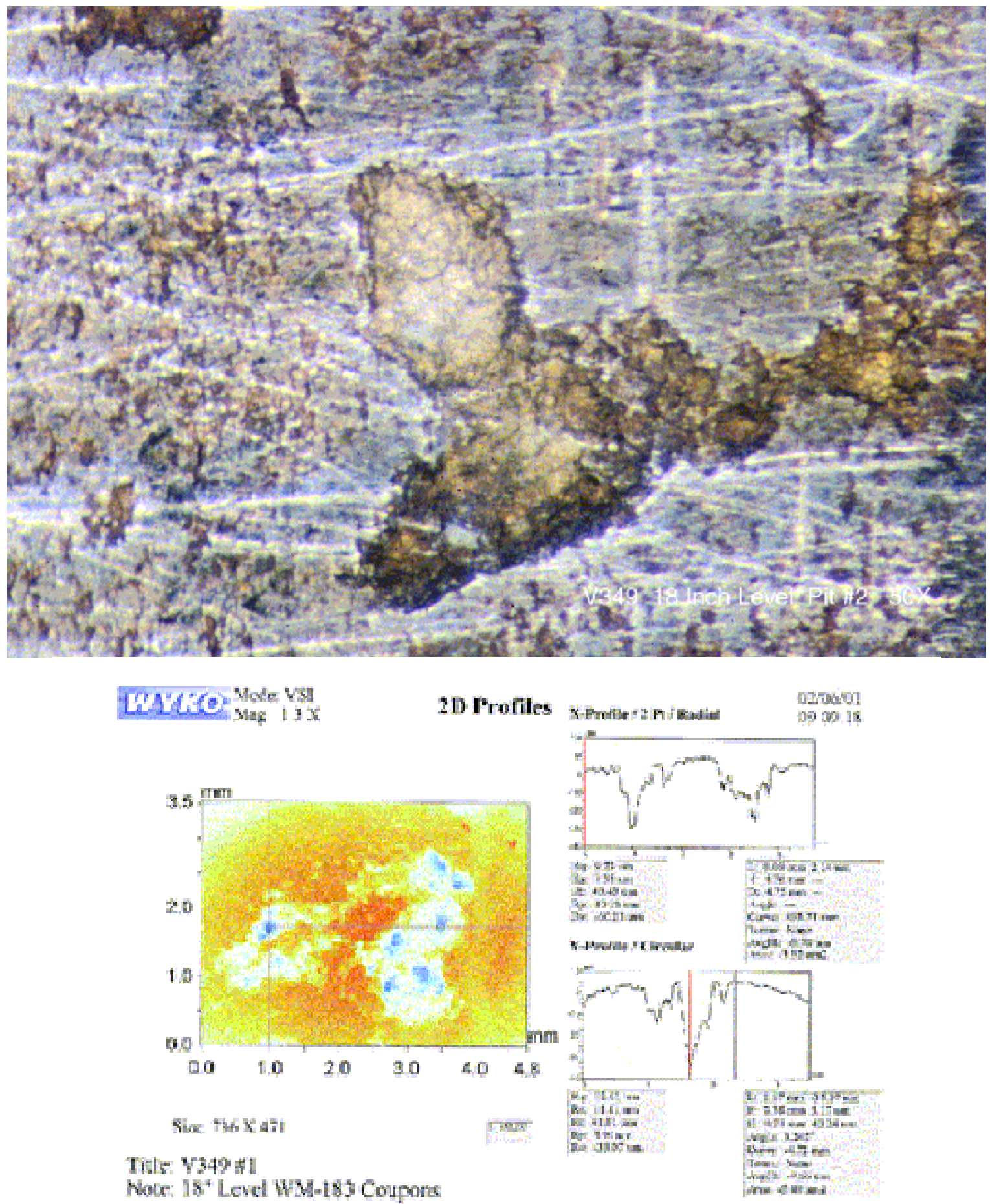

Figure C-15. Interferometer scan of Pit \#2 on Coupon V349 at the 45-cm (18-in.) level in Tank WM-183 (PD01-0066-56 and PD03-0029-18). ${ }^{8}$ 


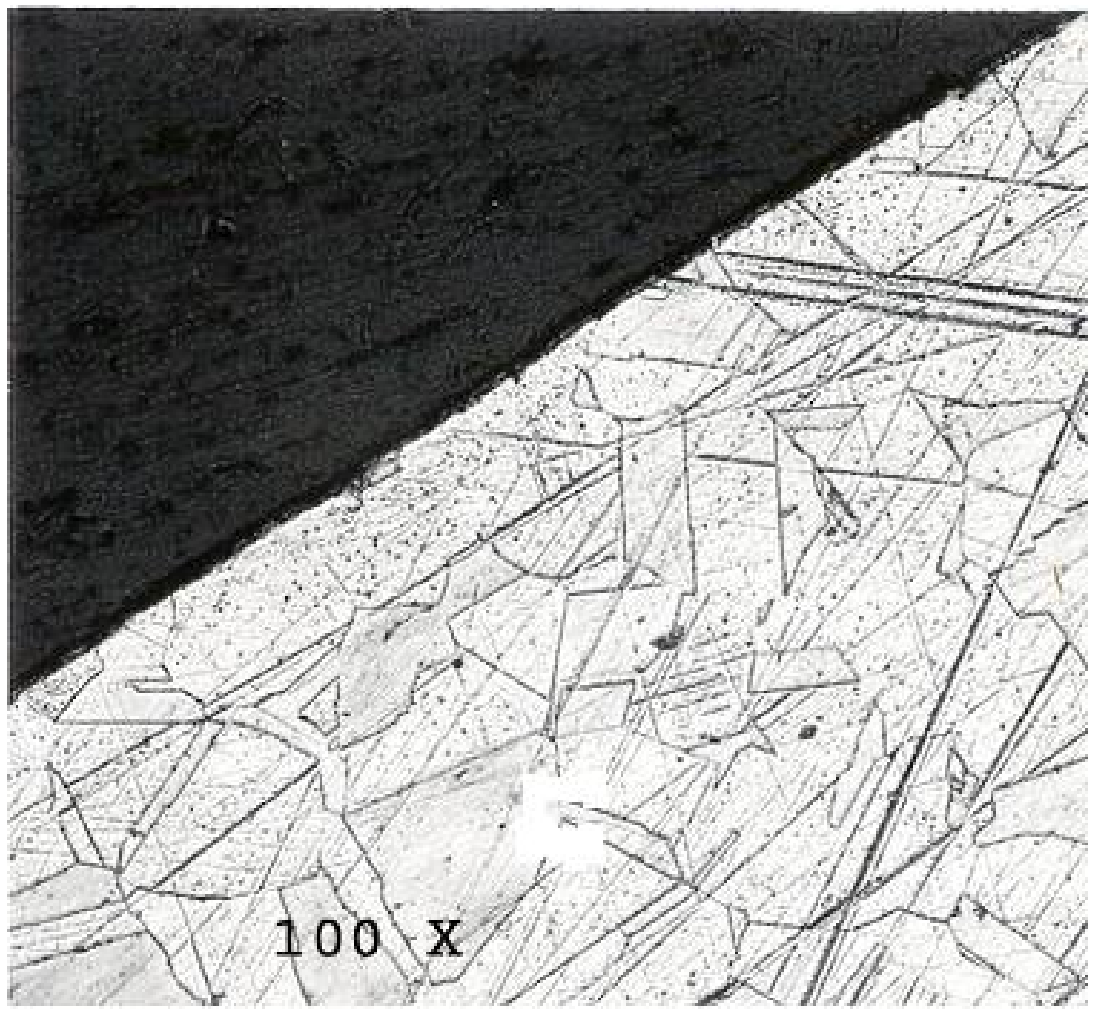

Figure C-16. Magnification (100x) of typical surface roughness on Coupon V349 at the 45-cm (18-in.) level in Tank WM-183 (PD03-0029-19). ${ }^{8}$

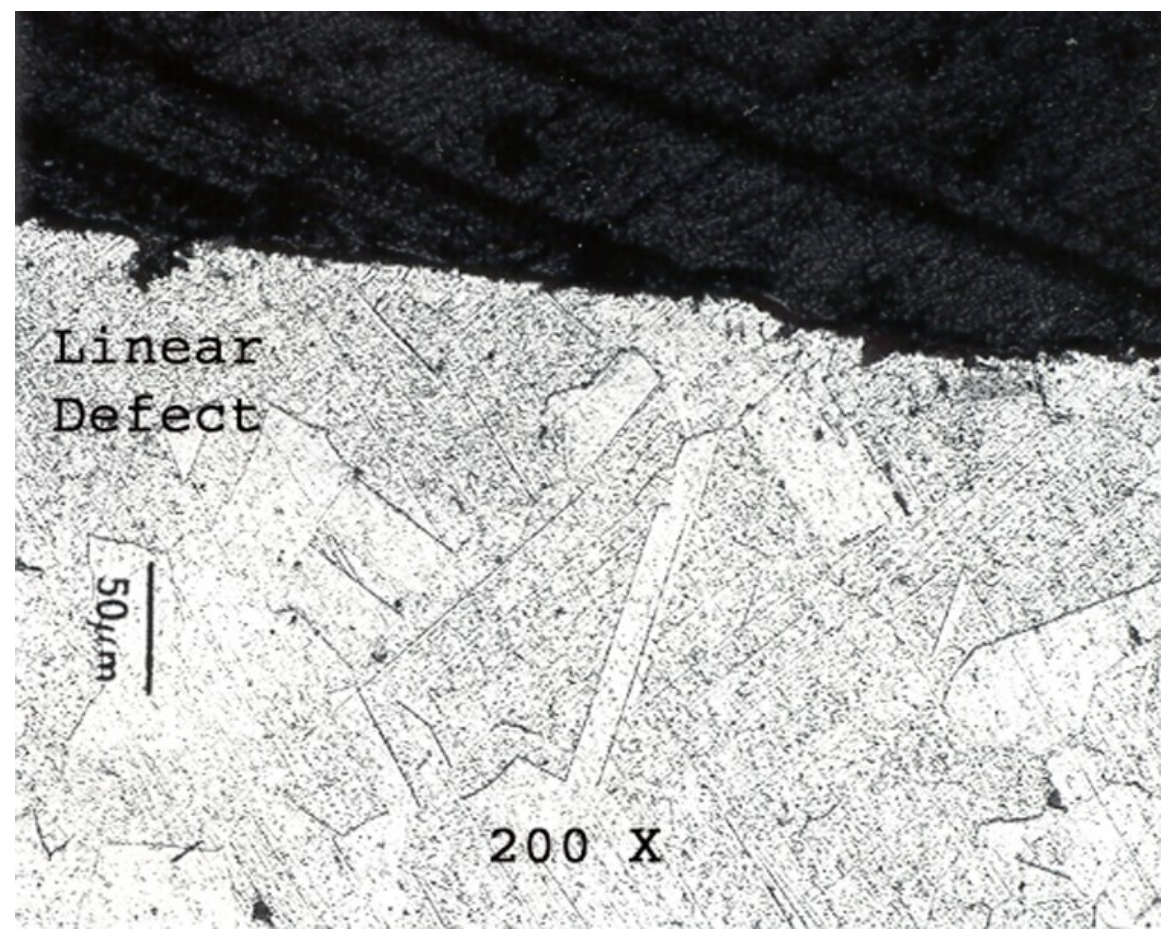

Figure C-17. Magnification (200x) of linear indication on Coupon V349 at the 45-cm (18-in.) level in Tank WM-183 (PD03-0029-20). ${ }^{8}$ 


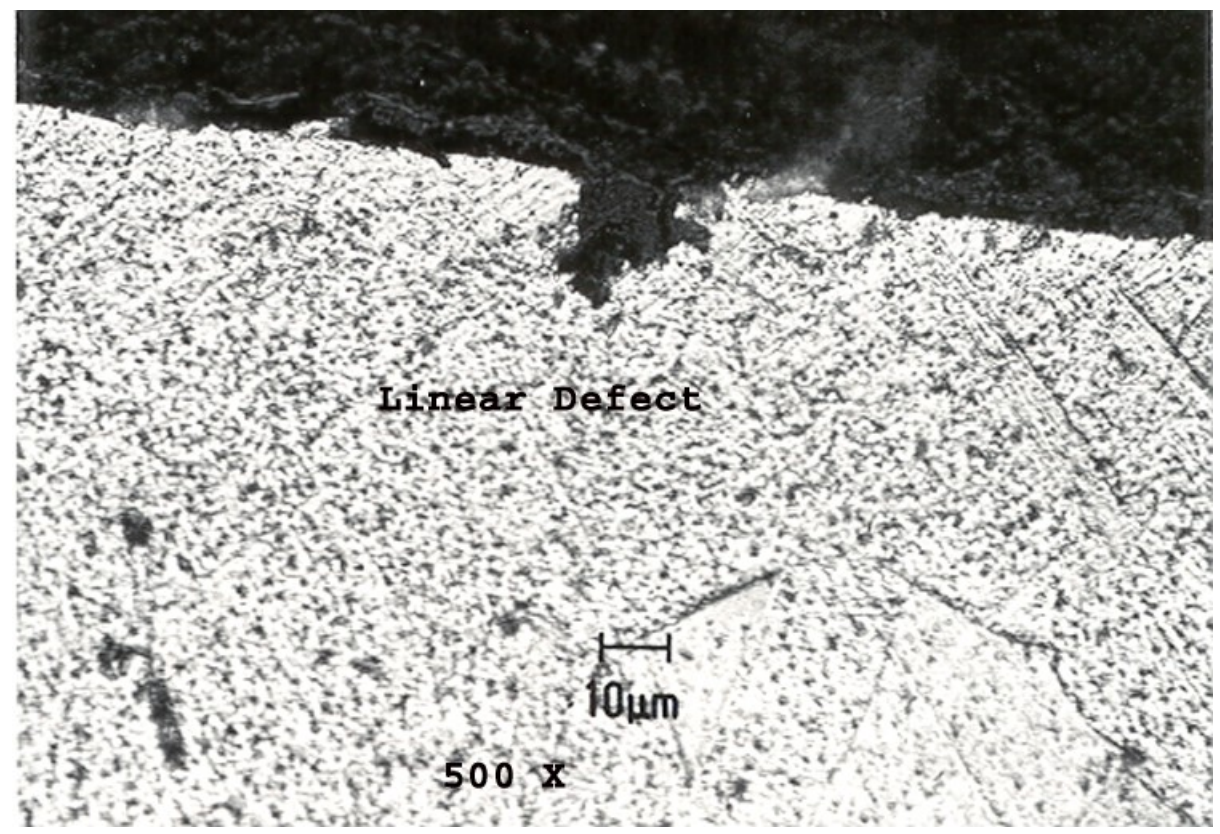

Figure C-18. Magnification (500×) of linear indication on Coupon V349 in Tank WM-183 (PD03-0029-21).

The highest average corrosion rate for a set of coupons exposed at any level in Tank WM-183 was $4.1 \times 10^{-3}$ mils per year at the bottom of the tank. ${ }^{8}$ At that rate, the metal loss for the tank calculates to 0.18 mils over the 42.8 years of service up to 1999 . The maximum corrosion rate observed for any single coupon from the tank was $3.3 \times 10^{-2}$ mils per year at the 0 -in. level, which calculates to a metal loss of 1.41 mils over the 42.8 years of vessel service up to 1999 . Tank WM-183 has a corrosion allowance of 50 mils (0.050 in.).

Visual examination of the seamless pipe corrosion coupons from Tank WM-183 under a binocular microscope at 10× magnification showed pit initiation. Figures C-19 through C-21 contain an interferometer picture and scanning electron microscope (SEM) photographs of a pit from Tank WM-183. The pit has steep walls, which are indicative of chemical pitting. In the past, a specific area of concern has been the bottom of the tank where accumulated solids could potentially cause accelerated general corrosion rates or localized corrosion attack. Examination of the five welded tank bottom coupons, in place since 1988, revealed an increase in general corrosion rates and pit initiation on one coupon. ${ }^{8}$ However, calculations using the maximum corrosion rate over the service life of the tank indicate a metal loss of only 1.4 mils versus a 50-mil corrosion allowance for the tank.

\section{C4. RESULTS FROM 2001 CORROSION COUPON RETRIEVAL}

On June 21, 2001, the corrosion test coupons were recovered from Tank WM-187 and decontaminated. ${ }^{9}$ The three coupon support jigs were found to be in contact with each other at the $45-\mathrm{cm}$ (18-in.) level. The coupon support jigs at the 183-cm (72-in.) and 122-cm (48-in.) level had slid down the cable and were in contact with the coupon support jig at the 45-cm (18-in.) level. The change in position was caused by general thinning of the cable, which loosened the set screws of the coupon support jigs. After the original corrosion coupons had been removed, the new corrosion coupons were added to the support jigs. However, during the lowering of the cable and coupon support jigs, the jigs apparently became unsecured and sheared off the end of the cable. All coupons and their support jigs, including the bottom level coupons, were lost to the bottom of the tank. The empty stainless steel cable remains 


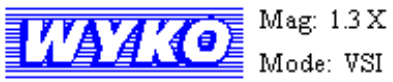

3-D Plot

Surface Statistics:
Ra: $7.81 \mathrm{um}$
Rq: $9.98 \mathrm{um}$
Rz: $53.93 \mathrm{um}$
Rt: 56.27 um
Set-up Parameters:
Size: 736 X 471
Sampling: 6.47 um
Processed Options:
Terms Removed:
Tilt
Filtering:
None

Title: V385

Note: 48" Level WM-183 Coupons
Date: $02 / 06 / 01$

Time: 13:10:22

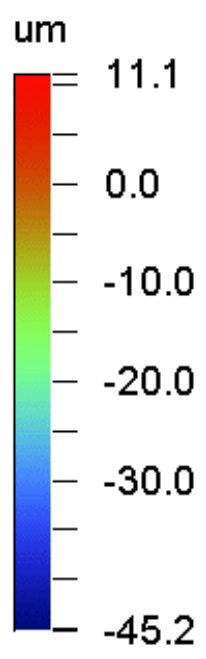

Figure C-19. Interferometer picture of pit on Coupon V385 in Tank WM-183 (PD03-0029-22). ${ }^{9}$

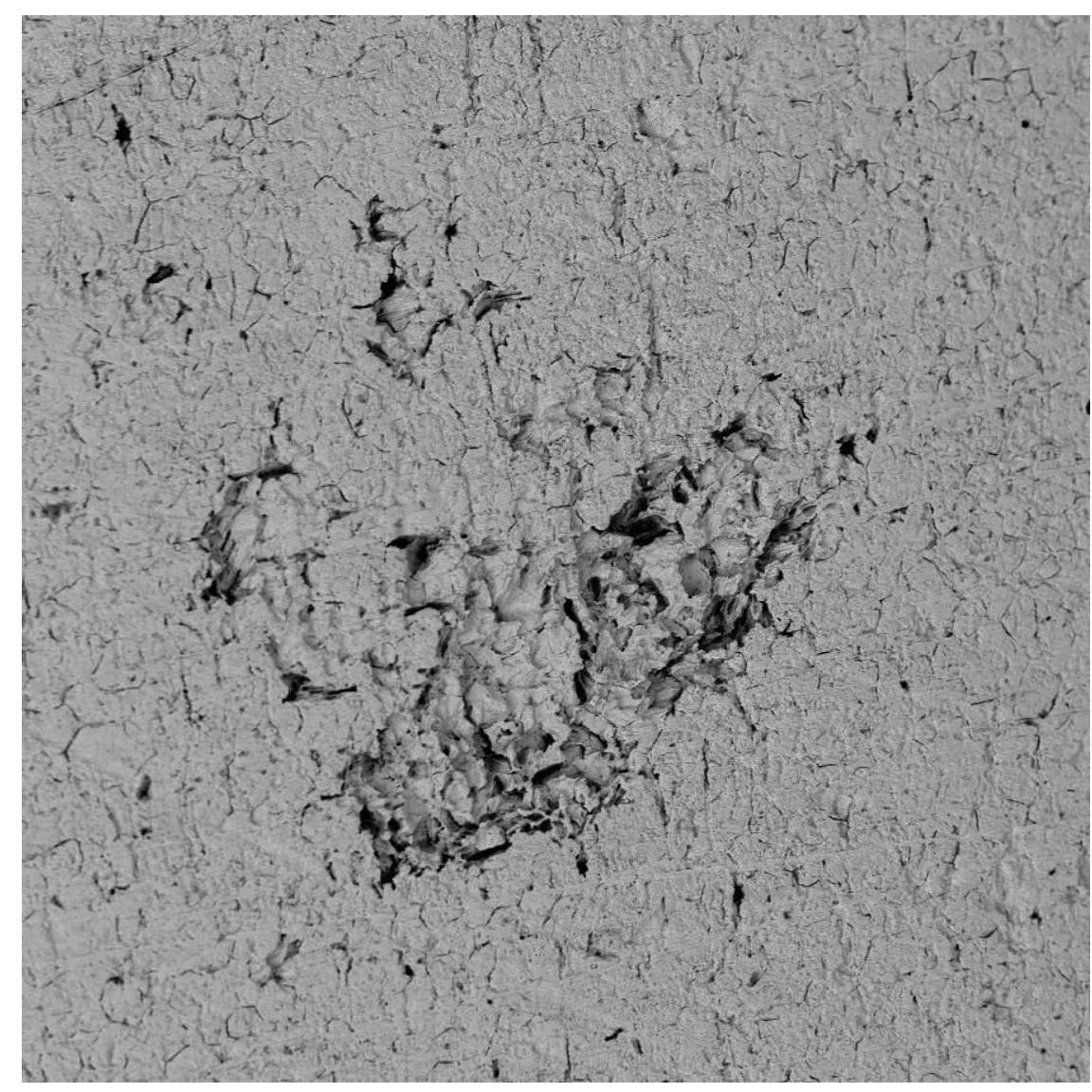

Figure C-20. Scanning electron microscope photograph at $100 \times$ magnification of pit on Coupon V385 in Tank WM-183 (PD03-0029-23). 


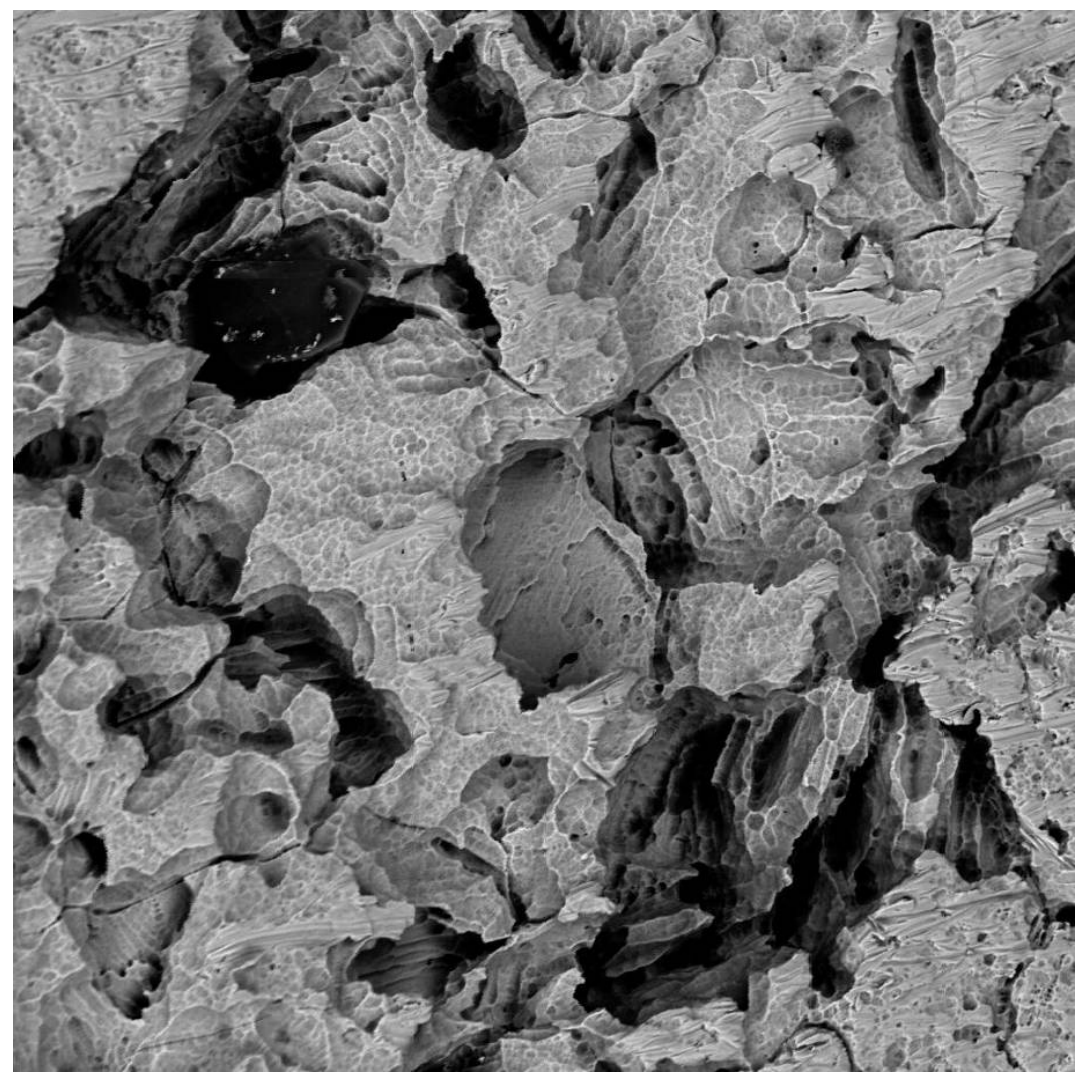

Figure C-21. Scanning electron microscope photograph at $600 \times$ magnification of the pit shown in Figure C-20 on Coupon V385 in Tank WM-183 (PD03-0029-24). ${ }^{9}$

attached to the underside of the tank riser flange. Nw corrosion coupons were inserted into Tank WM-187 in July 2003.

A total of 12 Type 304L stainless steel coupons were retrieved: three coupons from each of the four levels. ${ }^{9}$ Eight of these coupons were decontaminated and analyzed. Four coupons, one from each of the different levels, were segregated and left in their original condition. These coupons will be placed back into the tank when replacement corrosion coupons are installed. The appearance of the eight coupons after decontamination is shown in Figures C-22 through C-25.

The highest average corrosion rate for a set of coupons exposed at any level in Tank WM-187 was 0.029 mils per year and occurred at the $183-\mathrm{cm}(72-\mathrm{in}$.) level. At that rate, the maximum average metal loss calculates to 1.23 mils ( 0.0012 in. or $0.38 \%$ of the internal thickness of the tank wall) over 41.6 years of tank service. The maximum corrosion rate observed for any single coupon from this tank was 0.030 mil per year and also occurred at the $183-\mathrm{cm}$ (72-in.) level. Calculations using this maximum corrosion rate indicate a metal loss from the internal surfaces of the tank of 1.25 mils $(0.0013$ in. or $0.40 \%$ of the internal thickness of the tank wall) over the 41.6 years of tank service. ${ }^{9}$ Tank WM- 187 has a corrosion allowance of 50 mils (0.050 in.).

Visual examination of the welded pipe corrosion coupons under a binocular microscope at $10 \times$ magnification showed pit initiation. ${ }^{9}$ Examination of the two welded tank bottom coupons in Tank WM-187, in place since 1988, revealed no pit initiation. The highest corrosion rate was found on the coupons at the 183-cm (72-in.) level, while the bottom coupons had the lowest corrosion rate. This rate is similar to the rates found on the coupons retrieved from Tank WM-182. 


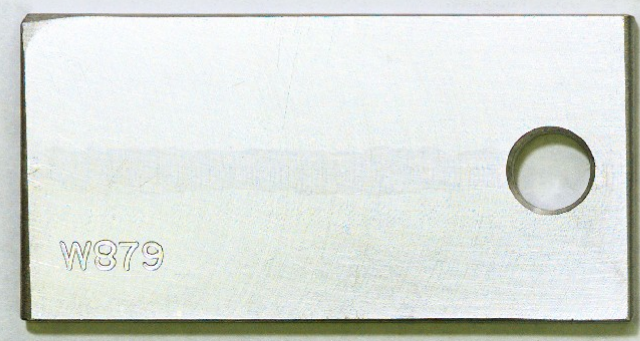

W879

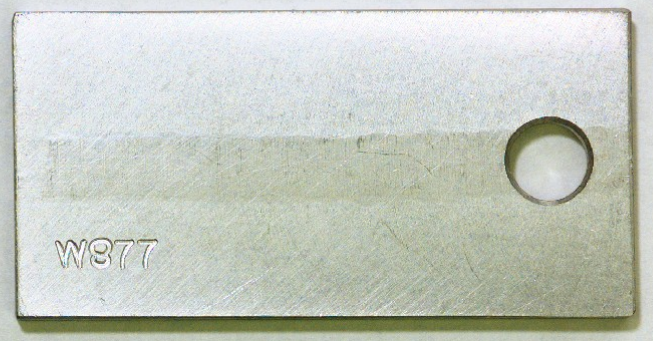

W877

WM-187 Corrosion Coupons Bottom Level

Figure C-22. Tank WM-187 coupons at the 0-in. level after 13.4 years of exposure (PD01-0406-14).

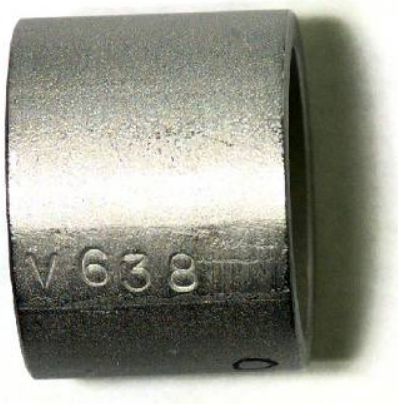

V638

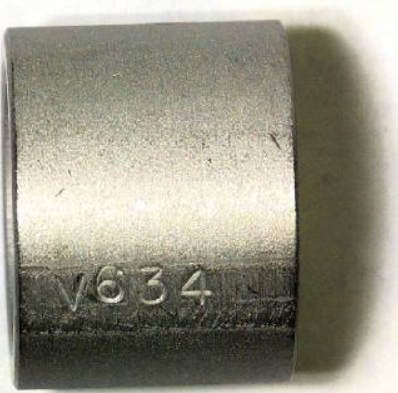

V634

\section{WM-187 Corrosion Coupons 18" Level}

Figure C-23. Tank WM-187 coupons at the 45 -cm (18-in.) level after 38.6 years of exposure (PD01-0406-16). 


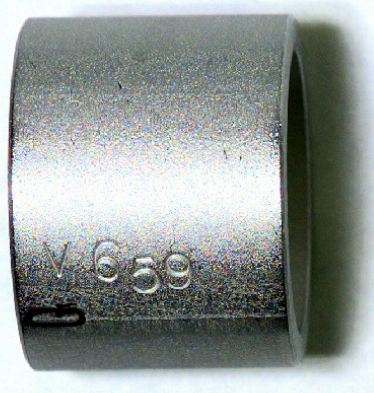

V659

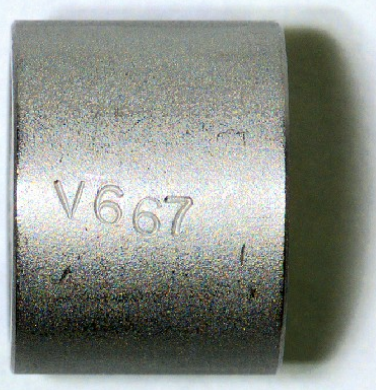

V667

\section{WM-187 Corrosion Coupons 48" Level}

Figure C-24. Tank WM-187 coupons at the 122-cm (48-in.) level after 36.7 years of exposure (PD01-0406-15).
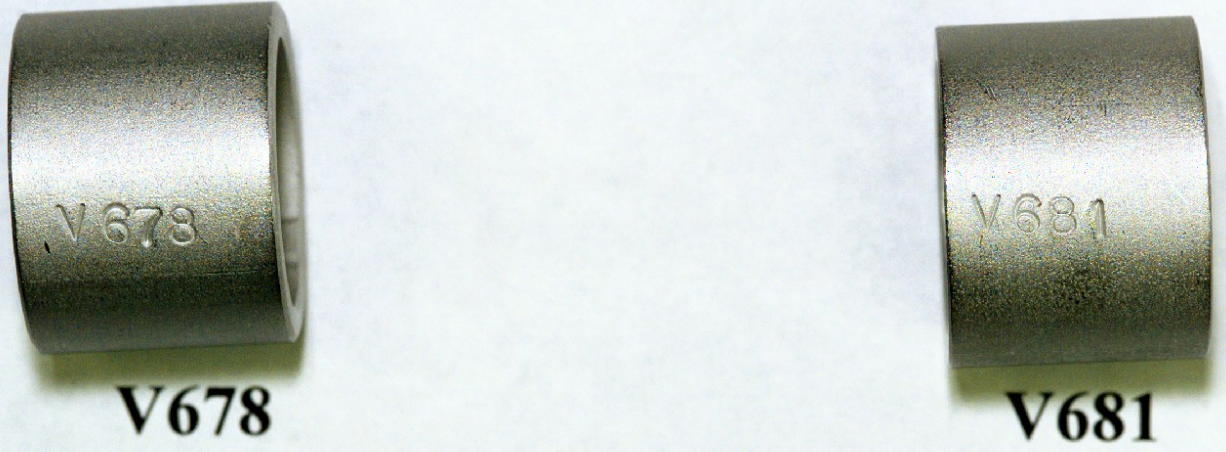

\section{WM-187 Corrosion Coupons 72" Level}

Figure C-25. Tank WM-187 coupons at the 183-cm (72-in.) level after 28.4 years of exposure (PD01-0406-12). 
The coupons were examined both with a binocular microscope and an optical interferometer to examine the surface and measure pit depths. Figure C-26 contains an interferometer depiction of a pit on Coupon V638. The pit on the coupon is very typical of what was seen on all of the coupons. Pit initiation was seen both in the base metal and in the welds. The maximum depth found on any pit from Tank WM-187 was 4.2 mils. The pits appear old and passivated because the bottoms of the pits have been etched. Alternatively, the pits that are now etched could have been surface imperfections on the original coupons. Figure C-27 is from a highly magnified SEM photograph of the pit on Coupon V638. On this picture, the bottom of the pit clearly has been etched. The etching contrasts with the pitting displayed in the SEM photographs of Tank WM-183 shown in Figures C-20 and C-21. The size and shape of the pits in Tank WM-187 indicate they may have initiated on a mechanical scratch or imperfection. ${ }^{9}$

A total of 18 Type 304L stainless steel coupons were retrieved from Tank WM-189 on November 8, 2001: six were retrieved from the 183-cm (72-in.) level, six were retrieved from the 122-cm (48-in.) level, four were retrieved from the $45-\mathrm{cm}(18$-in.) level, and two were retrieved from the bottom assembly. All eighteen of these coupons were decontaminated and analyzed. Tank WM-189 contained welded pipe section coupons, unwelded pipe section coupons, as well as the rectangular bottom coupons. ${ }^{9}$ An example of the appearance of these coupons after decontamination is shown in Figure C-28.

The highest average corrosion rate for a set of coupons exposed at any level in Tank WM-189 was 0.009 mil per year and occurred at the $183-\mathrm{cm}\left(72-\mathrm{in}\right.$.) level. ${ }^{9}$ At that rate, the average metal loss calculates to 0.320 mil ( 0.0003 in. or $0.10 \%$ of the internal thickness of the tank wall) over 35.4 years of tank service. The maximum corrosion rate observed for any single coupon from this tank was nearly the same at 0.01 mil per year and also occurred at the $183-\mathrm{cm}$ (72-in.) level. This rate occurred on a coupon containing a weld. Calculations using this maximum corrosion rate indicate a metal loss from the internal surfaces of the vessel of 0.354 mil (0.0004 in. or $0.13 \%$ of the internal thickness of the tank wall) over the 35.4 years of tank service. While the individual coupon corrosion rates from each level were very close to each other, the coupons containing welds tended to generate higher corrosion rates because most localized corrosion was occurring at the weld heat-affected-zone. Tank WM-189 has a corrosion allowance of 50 mils (0.050 in.). ${ }^{9}$

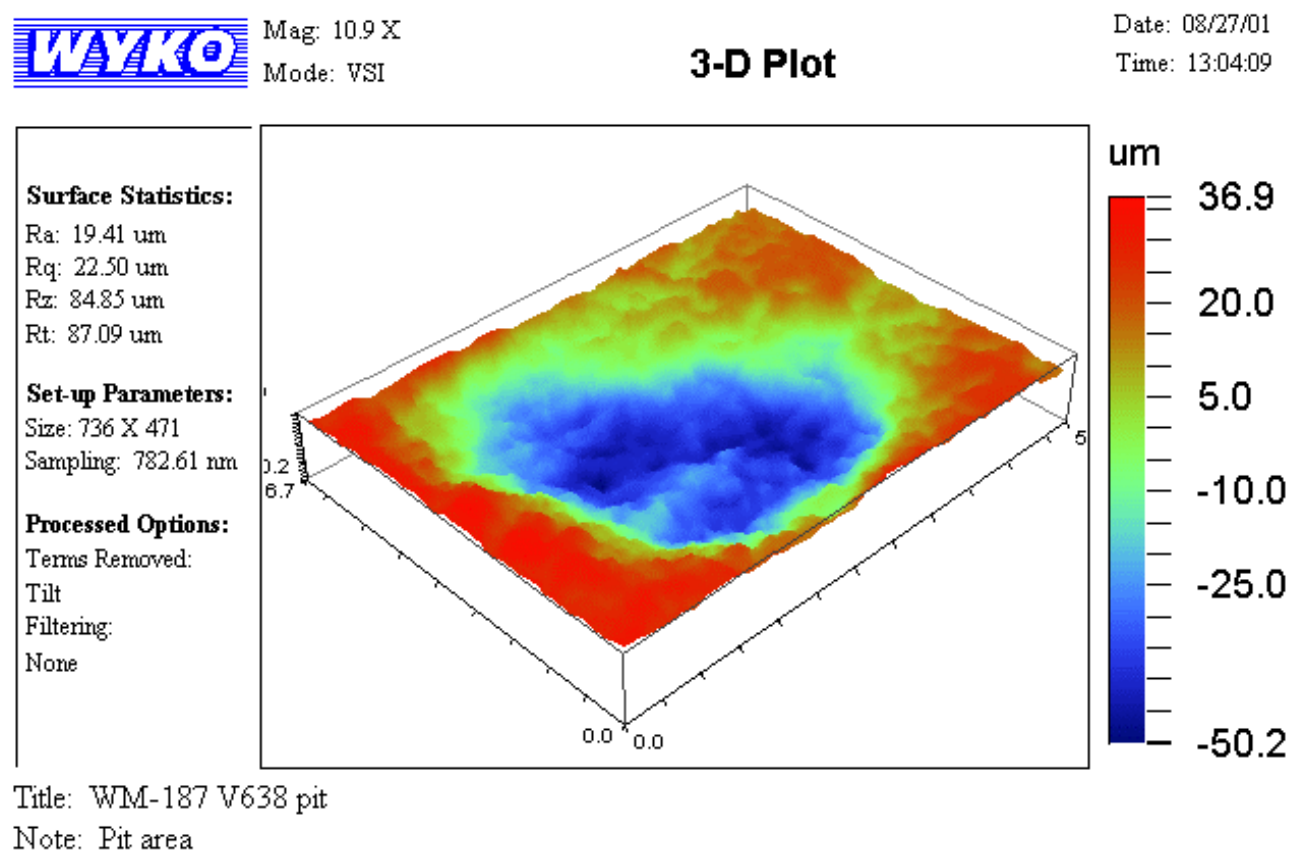

Figure C-26. Interferometer depiction of pit on Coupon V638 in Tank WM-187 (PD03-0029-25). ${ }^{9}$ 


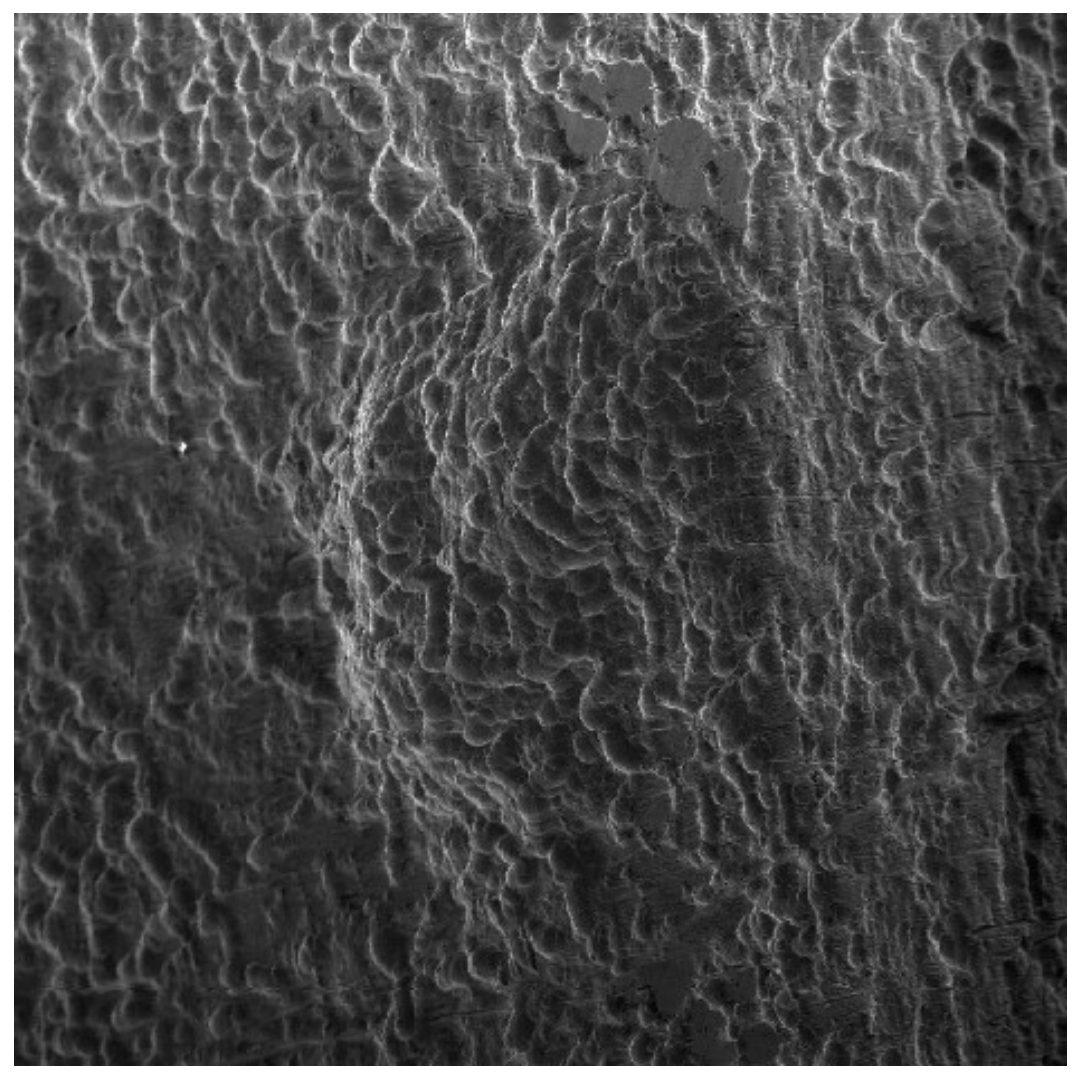

Figure C-27. Scanning electron microscope photograph (150×) of pit on Coupon V638 in Tank WM-187 (PD03-0029-26). ${ }^{9}$

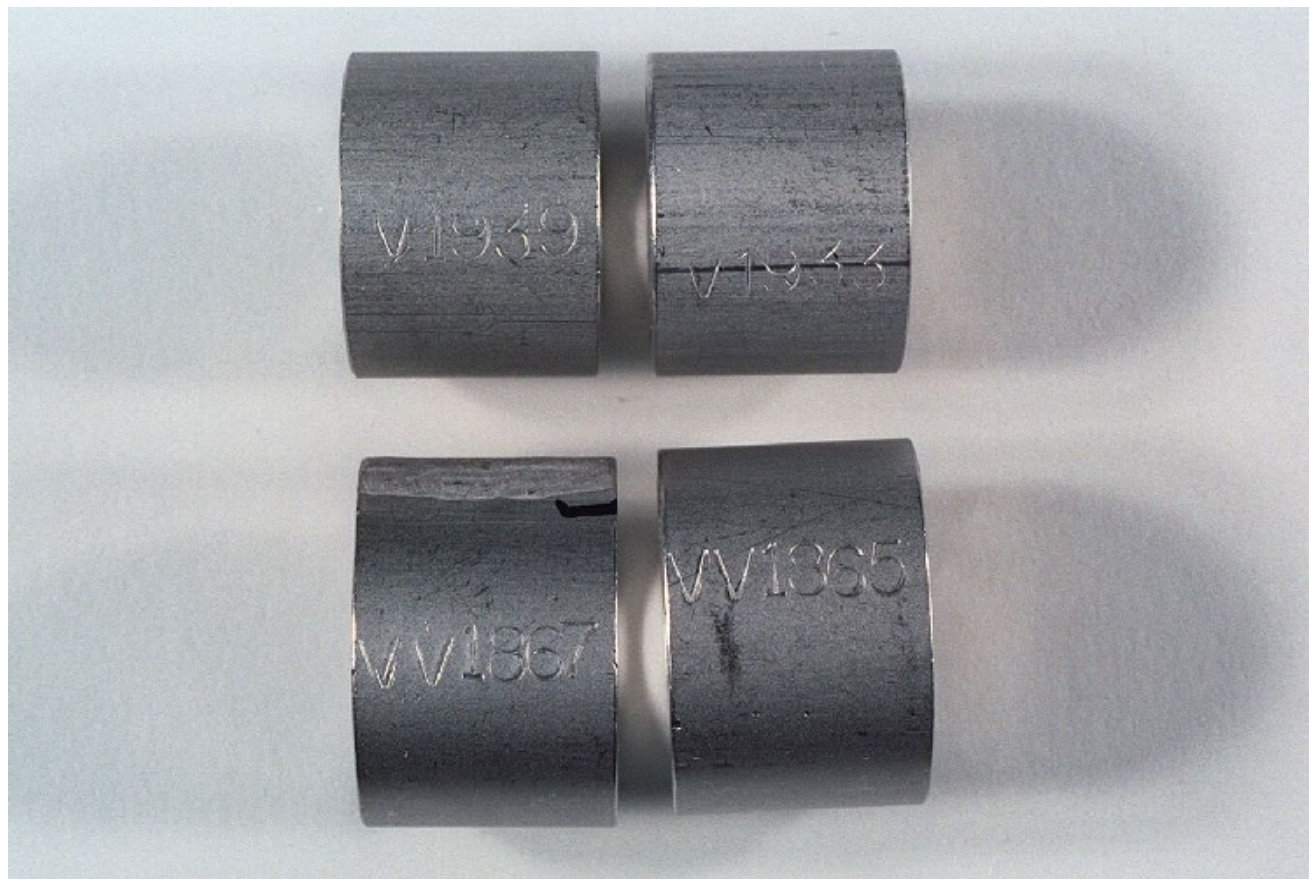

Figure C-28. Tank WM-189 corrosion coupons at the 45-cm (18-in.) level retrieved in 2001 (PN02-0152-1-7). ${ }^{9}$ 
Visual examination of the corrosion coupons under a binocular microscope showed pit initiation similar to that in Tank WM-187. Examination of the three welded coupons at the tank bottom, in place since 1988, revealed only minor end-grain attack on the longitudinal edges of the rectangular coupons. This end-grain attack is not expected to be a problem in the tanks because the end grains of the tank plates are not exposed to the waste solution. ${ }^{9}$

The coupons were examined both with a binocular microscope and an optical interferometer to examine the surface and measure pit depths. Figure C-29 contains an interferometer depiction of a pit on Coupon VV1867. Figure C-30 is a SEM photograph of attack at the heat-affected zone on Coupon VV1867. The corrosion attack on the coupon is very typical of what was seen on all of the coupons. The pits appear etched and have broader and shallower edges than those found in Tank WM-183. Most of the coupons have end-grain corrosion initiating, but it is not very pronounced. ${ }^{9}$

\section{C5. RESULTS FROM 2002 CORROSION COUPON RETRIEVAL}

On May 28, 2002, a total of eight Type 304L stainless steel coupons were retrieved from Tank WM-188: two were retrieved from the $183-\mathrm{cm}(72-\mathrm{in}$.$) level, three were retrieved from the 122-\mathrm{cm}$ (48-in.) level, and three were retrieved from the bottom assembly. ${ }^{9}$ All eight of these coupons were decontaminated and analyzed. The appearance of the eight coupons after decontamination is shown in Figure C-31.

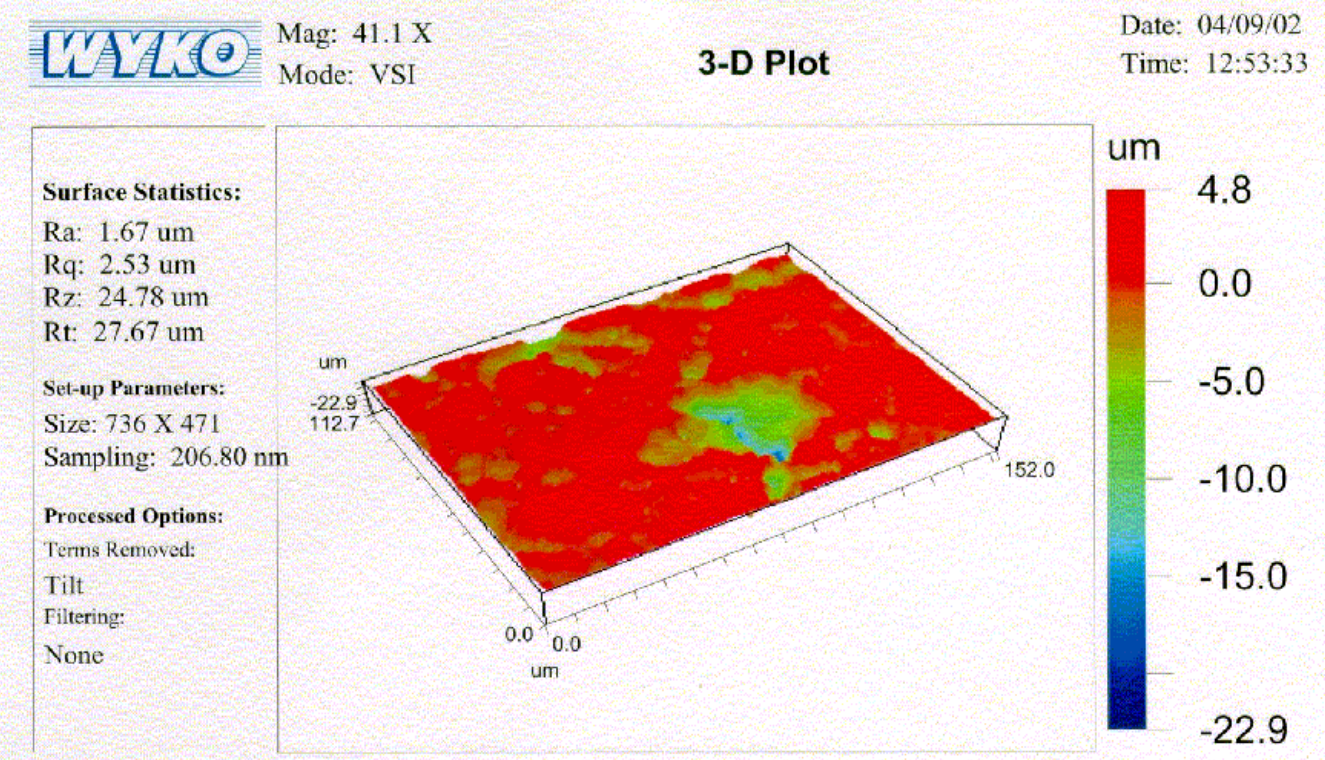

Title: VV1867

Note: Attack of HAZ

Figure C-29. Interferometer depiction of heat-affected zone attack on Coupon VV1867 in Tank WM-189 (PD03-0029-27). ${ }^{9}$ 


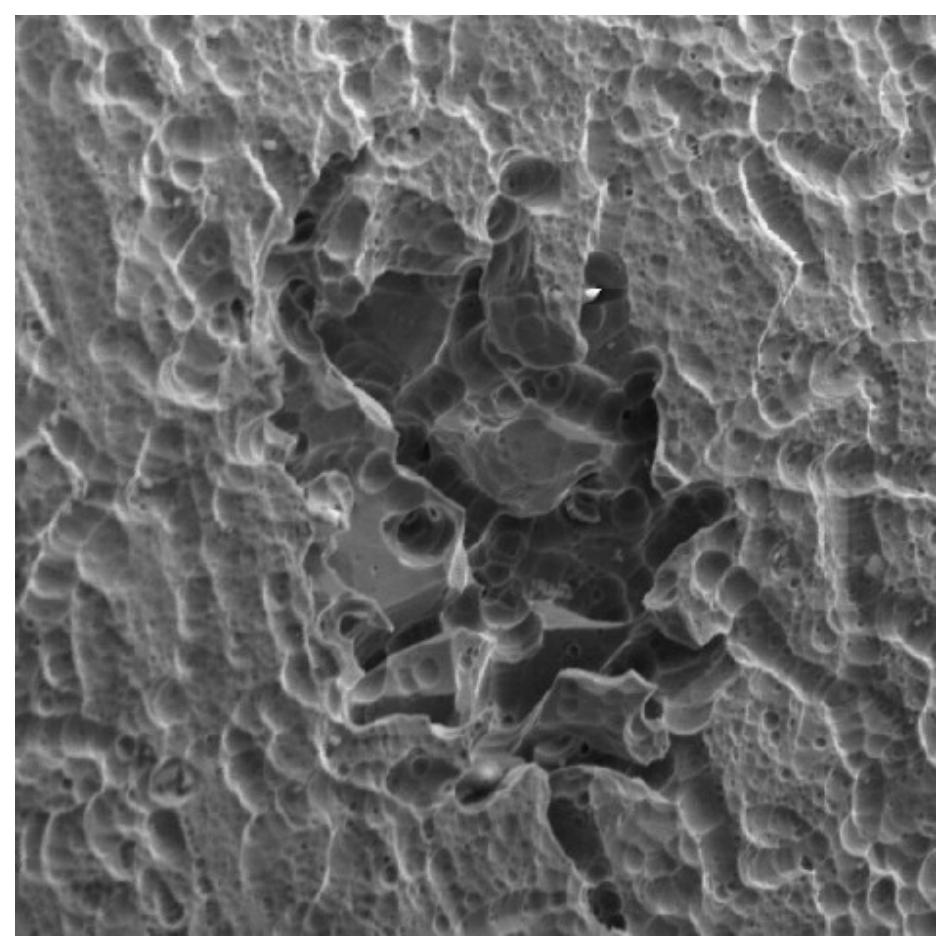

Figure C-30. Scanning electron microscope photograph $(680 \times)$ of heat-affected zone attack on Coupon VV1867 in Tank WM-189 (PD03-0029-28). ${ }^{9}$

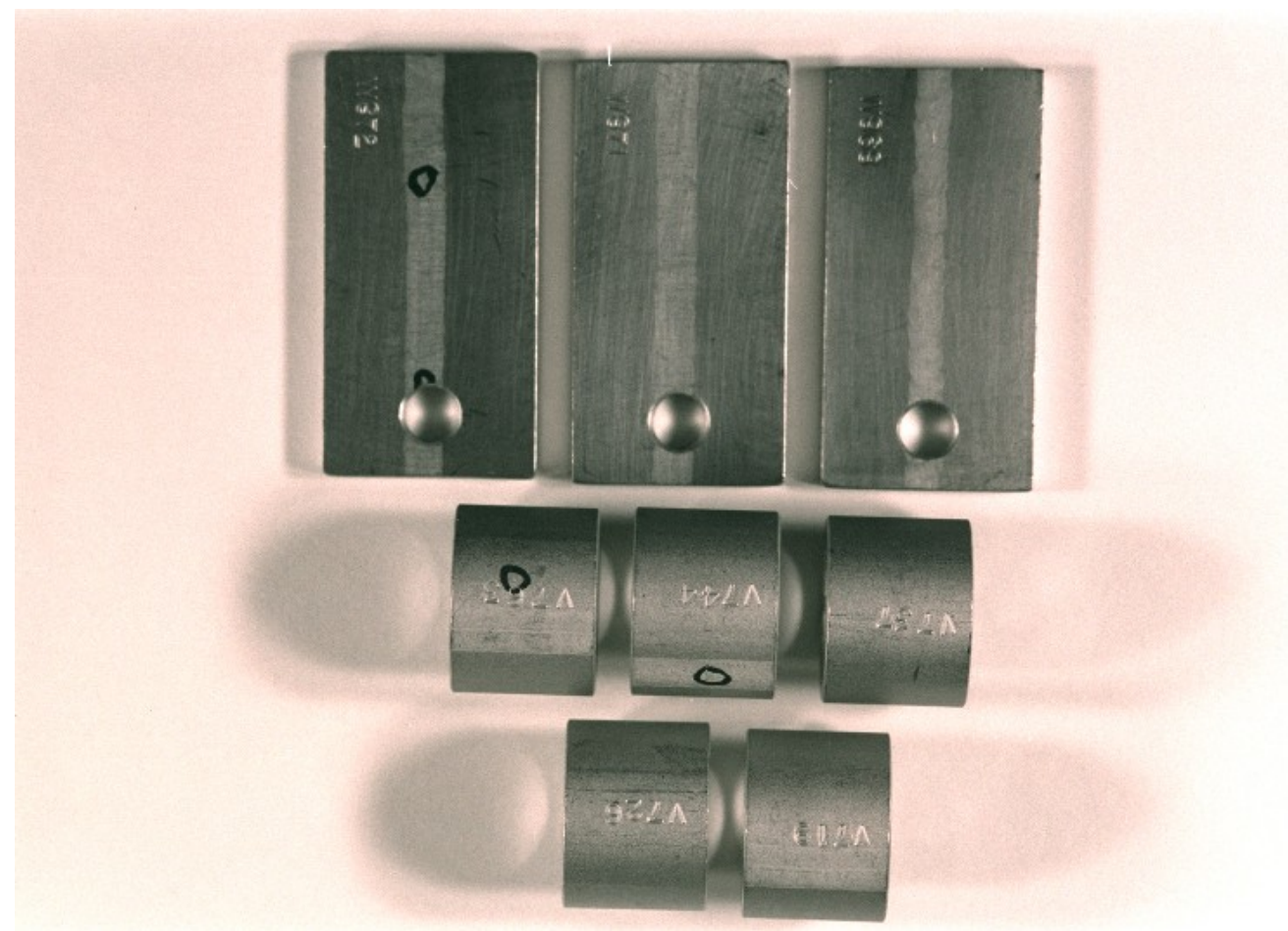

Figure C-31. Tank WM-188 corrosion coupons retrieved in 2002 (PN02-389-1-17). ${ }^{9}$ 
The highest calculated average corrosion rate for a set of coupons exposed at any level in Tank WM-188 was 0.042 mil per year and occurred at the $122-\mathrm{cm}\left(48\right.$-in.) level. ${ }^{9}$ At that rate, the maximum average metal loss calculates to 1.58 mils $(0.0016$ in. or $0.51 \%$ of the internal thickness of the tank wall) over 37.9 years of tank service. The maximum corrosion rate observed for any single coupon from this tank was nearly the same at 0.043 mil per year and also occurred at the 122 -cm (48-in.) level. ${ }^{9}$

Calculations using this maximum corrosion rate also indicate a metal loss from the internal surfaces of the tank of 1.63 mils ( 0.0016 in. or $0.51 \%$ of the internal thickness of the tank wall) over the 37.9 years of tank service. Tank WM-188 has a corrosion allowance of 50 mils (0.050 in.).

Visual examination of the corrosion coupons under a binocular microscope showed pit initiation similar to the coupons in Tank WM-187. Examination of the three welded tank bottom coupons, in place since 1988, revealed minor end-grain attack on the longitudinal edges of the rectangular coupons. The highest corrosion rates were found on the coupons at the $183-\mathrm{cm}(72-\mathrm{in}$.$) and 122-cm (48-in.) levels,$ while the bottom coupons had the lowest corrosion rate. This is similar to the results found on the coupons retrieved from Tanks WM-182 and WM-187.

The coupons were examined both with a binocular microscope and an optical interferometer to examine the surface and measure pit depths. The maximum depth found on any pit from Tank WM-188 was the same as for Tank WM-187, 4.2 mils. ${ }^{9}$ Figure C-32 contains an interferometer depiction of weld attack on Coupon V744. Figure C-33 is a SEM photograph of the same weld attack at high magnification. The pit appears old because the bottom has been etched. Even the interior of this pit appears to be etched to the same degree as the upper coupon surfaces. This evidence indicates that these pits probably are not currently active. By again looking at the SEM photograph in Figure C-21 of the pit in Tank WM-183, the differences between pits in the two tanks can be seen. Many of the coupons also showed the initiation of end-grain attack. This end-grain attack is not expected to be a problem in the tanks because the end grains in the tank plates are not exposed to the waste solution. The welds were attacked on most of the coupons examined. ${ }^{9}$

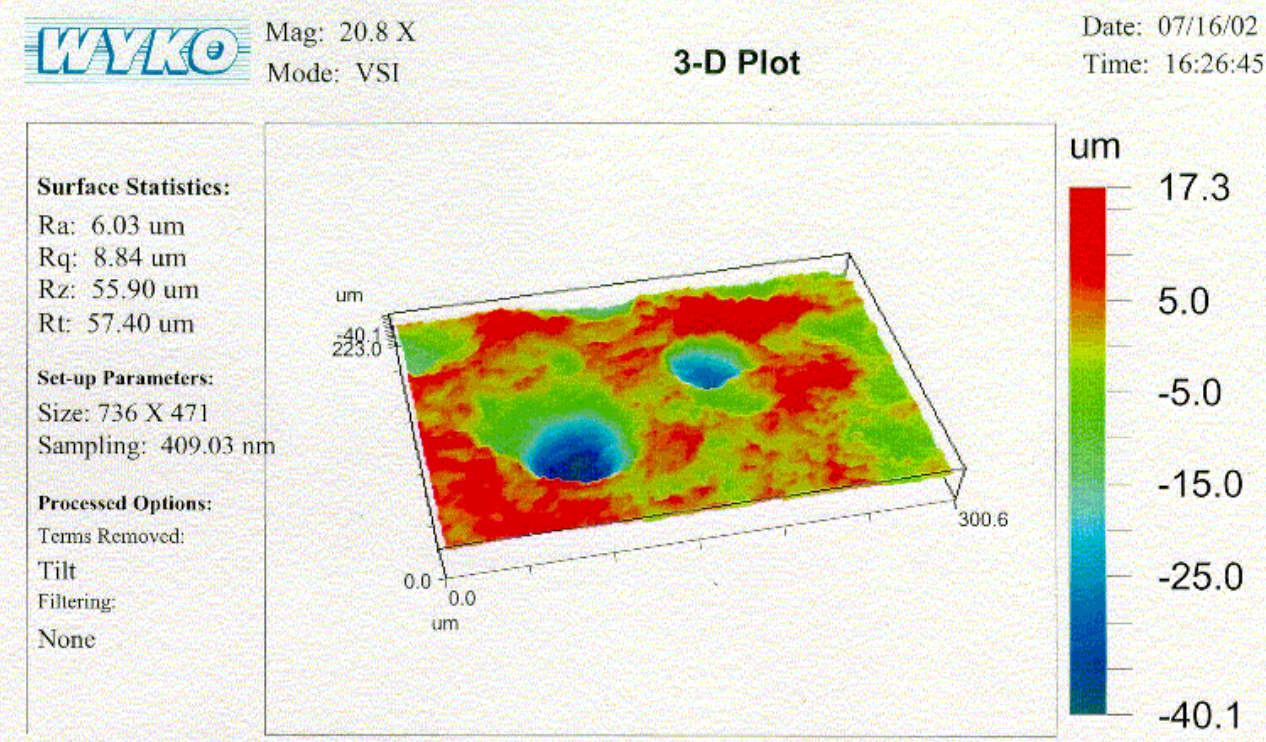

Title: WM-188 V744

Note: WELD ATTACK

Figure C-32. Interferometer depiction of weld attack on Coupon V744 in Tank WM-188 (PD03-0029-29). ${ }^{9}$ 


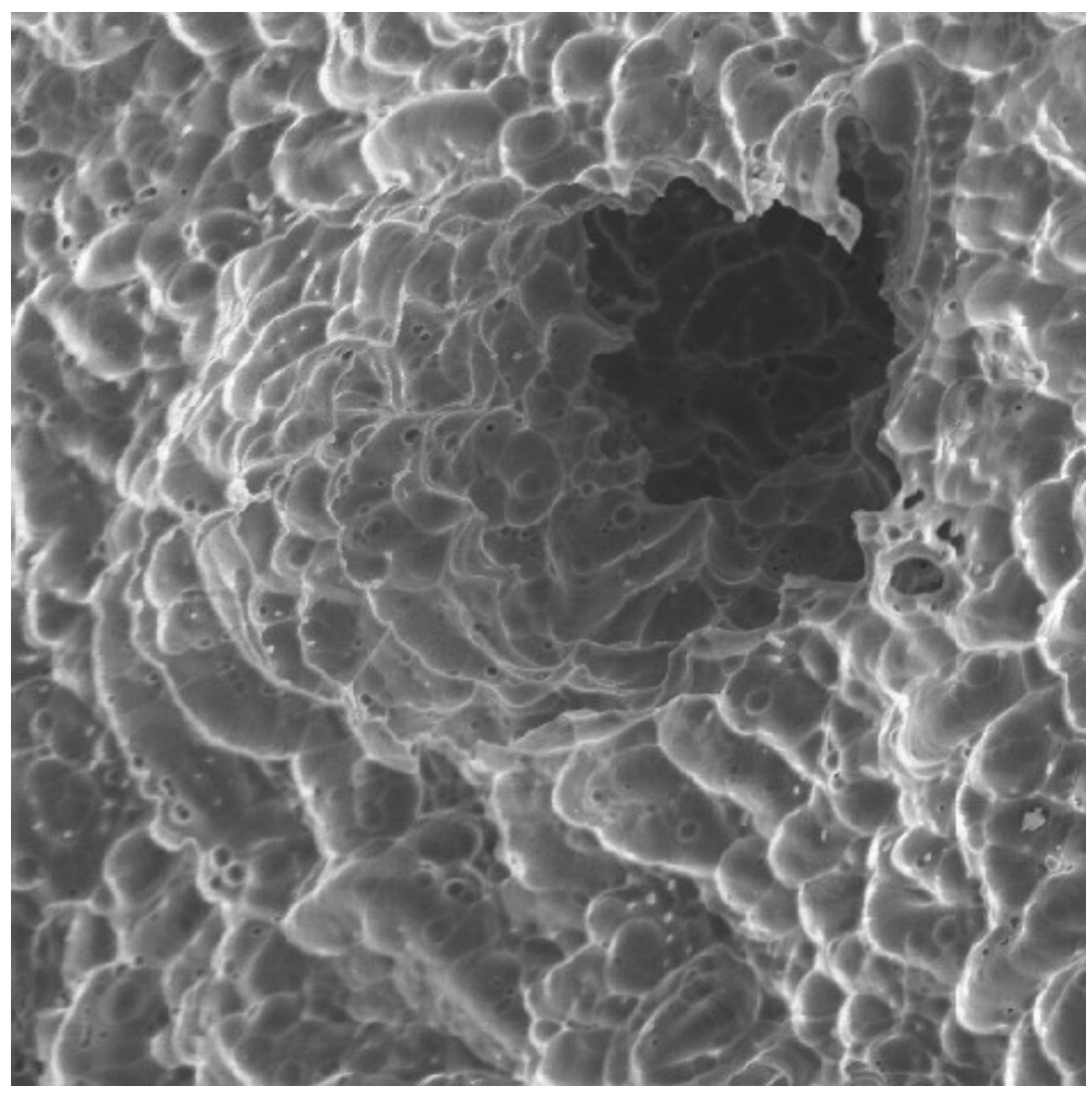

Figure C-33. Scanning electron microscope photograph $(800 \times)$ of weld attack on Coupon V744 in Tank WM-188 (PD03-0029-30). ${ }^{9}$

Corrosion test coupons were recovered from Tank WM-180 on June 5, 2002. ${ }^{9}$ Only three Type 304L stainless steel coupons from the bottom of the tank were removed. The pipe section coupons on the coupon support jigs were unretrievable because of the way the jigs had tangled together at the bottom of the cable. All three of the coupons from the bottom of the tank were decontaminated and analyzed. ${ }^{9}$ The coupons retrieved from the bottom of the tank are shown in Figure C-34.

The average corrosion rate for the bottom coupons in Tank WM-180 was 0.0003 mil per year and occurred at the bottom level. ${ }^{9}$ At that rate, the maximum average metal loss calculates to 0.014 mil ( 0.000014 in. or $0.005 \%$ of the internal thickness of the tank wall) over 47.7 years of vessel service. The maximum corrosion rate observed for any single coupon from this tank was 0.0004 mil per year and also occurred at the bottom level. Calculations using the maximum corrosion rate for the tank indicate a metal loss from the internal surfaces of 0.019 mil $(0.00002$ in. or $0.006 \%$ of the internal thickness of the tank wall) over the 47.7 years of tank service. Tank WM-180 has a corrosion allowance of 50 mils (0.050 in.).

Examination of the three welded coupons at the tank bottom, in place since 1988, revealed no indications of localized corrosion. While the low corrosion rate and lack of localized corrosion on the bottom coupons are good indicators that the tank is in excellent condition, the data from the Tank WM-180 pipe section coupons are missing. Similarly, Tank WM-187 had no indications of localized corrosion on its bottom coupons, but did on the pipe section coupons. Lacking the pipe section coupons, a complete evaluation of Tank WM-180 cannot be made. ${ }^{9}$ 


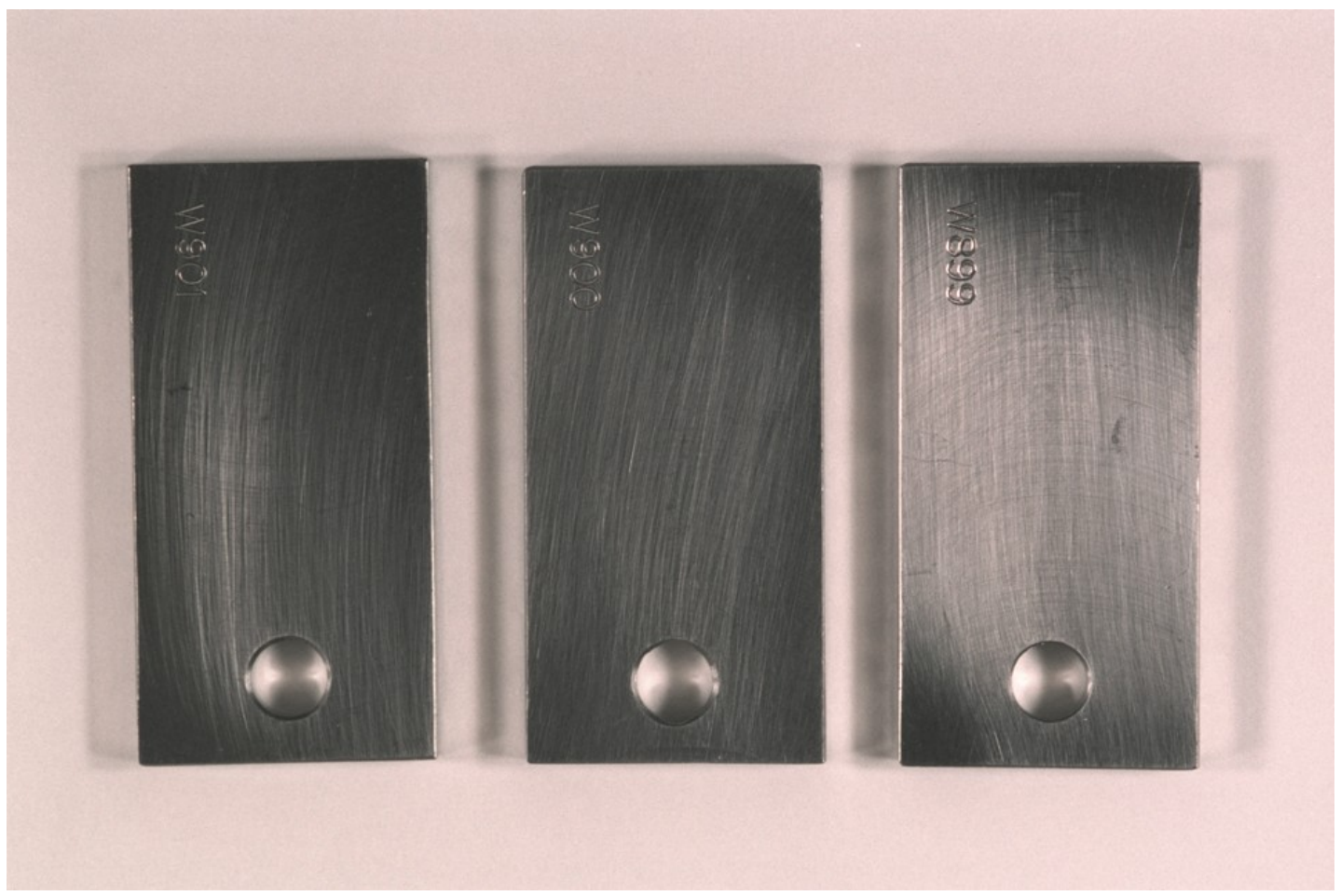

Figure C-34. Tank WM-180 corrosion coupons retrieved in 2002 (PN02-389-1-3). ${ }^{9}$

During the corrosion coupon retrievals of 2001 and 2002, new corrosion coupons were added to the existing coupon support jigs of Tanks WM-187, WM-188, and WM-189. In addition, new bottom-level coupons were added to these tanks and Tank WM-180. The types of new corrosion coupons consisted of immersion, crevice, and U-bend coupons (see Figure C-35). The coupons were mounted on a weld wire loop that was welded into a circle $7.6 \mathrm{~cm}$ (3 in.) in diameter. These hoops of coupons were easily added to the hooks of the coupon support jigs. However, in Tank WM-187 all coupons and their support jigs were lost to the bottom of tank. ${ }^{9}$ New corrosion coupons were inserted into Tank WM-187 in July 2003.

A reevaluation of the Tank WM-182 corrosion coupons pulled in 1999 was performed in 2002 based on the same criteria used in evaluating other tanks. This evaluation confirmed the presence of pitting, and identified the maximum depth found on any pit as 2.8 mils. ${ }^{10}$ Pictures of these pits generated from a white light interferometer are documented in Figures C-36 through C-40. Because of equipment problems, SEM photographs are not available. Figure C-36 displays the minor end-grain corrosion that has been evident on most of the recently evaluated corrosion coupons in the tanks. Figure C-37 depicts a pit site that appears to be no longer active. The bottom surface of this pit has been etched. Figure C-37, in particular, is very typical of what was seen in Tanks WM-187, WM-188, and WM-189 as indicated above. These pits have smoother sides and have a rounder shape. The pit in Figure C-37 also tends to be indicative of pit initiation on a mechanical flaw on the coupon surface.

Figures C-38 and C-39 represent pits more similar to those that were seen in Tank WM-183 (see Figures C-20 and C-21). The pits shown in the figures tend to have steeper walls and have a more jagged shape to them. These pits tend to be more indicative of chemical attack pit initiation. Lacking the SEM, a determination cannot be made whether the bottom surface of these pits became etched or if they were still active. Many of the pits found in Tank WM-183 were not etched. ${ }^{10}$ 


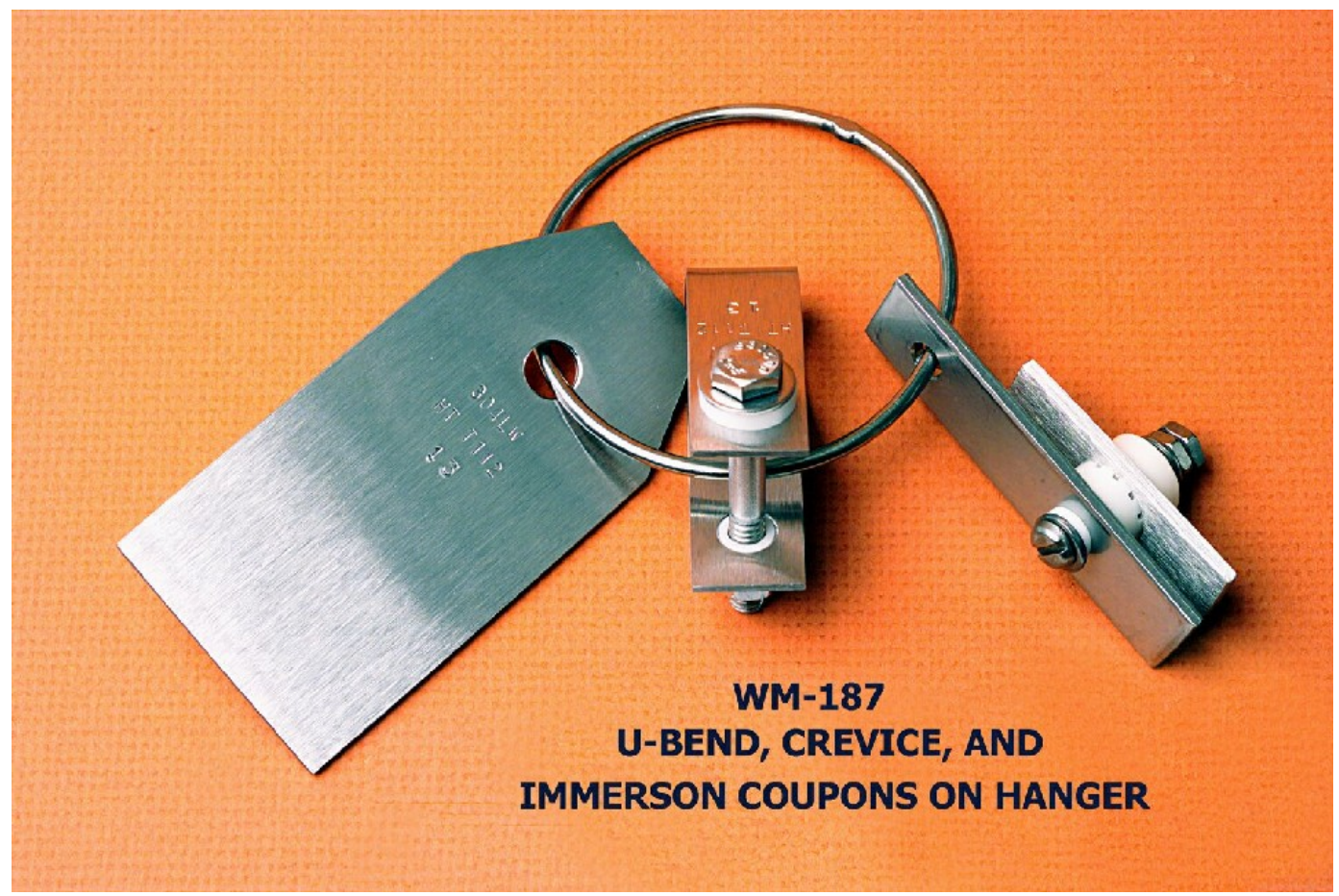

Figure C-35. Types of new corrosion coupons added to the 300,000-gal tanks during 2001 and 2002 (PD01-152-2-6).

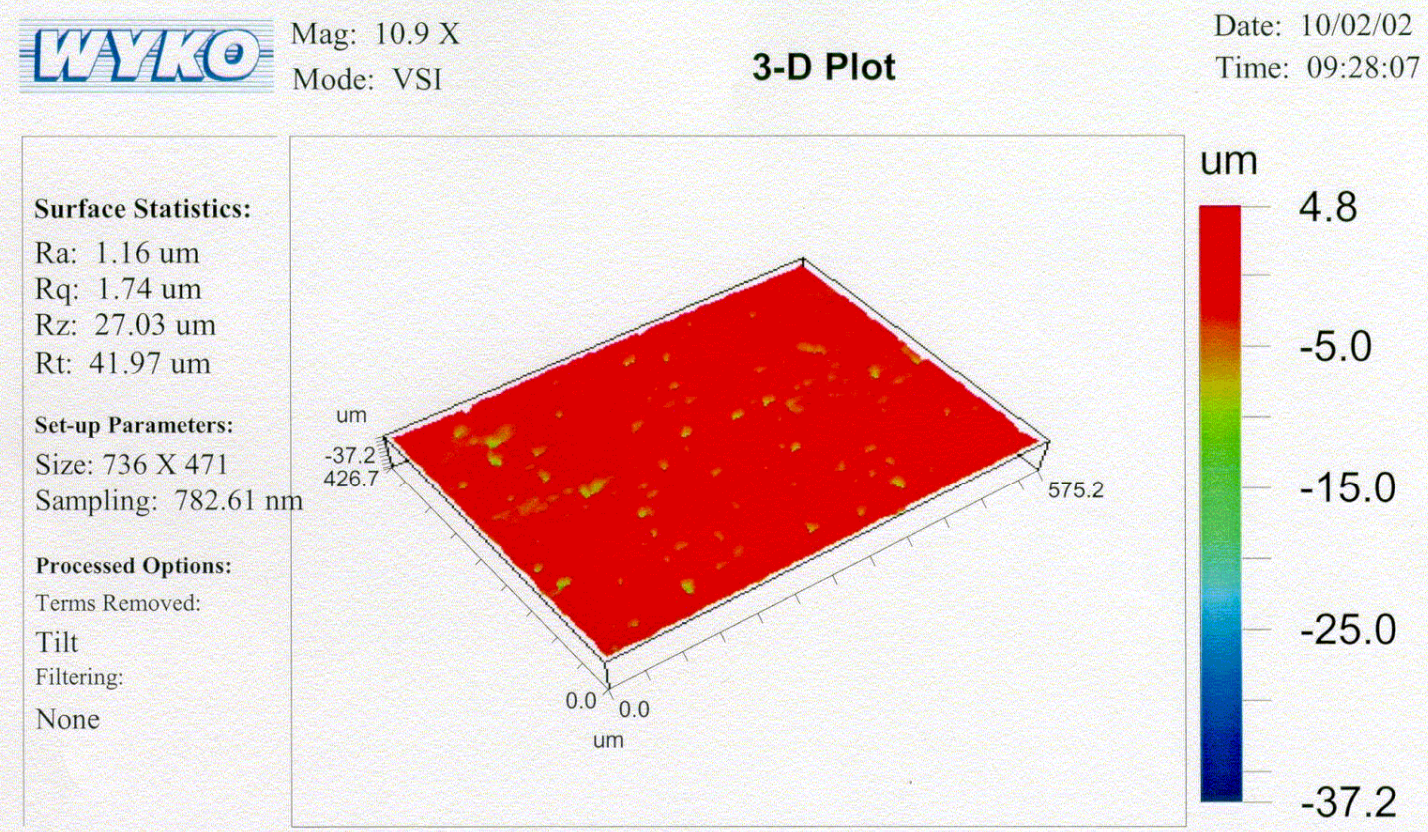

Title: WM-182 V326

Note: End Grain

Figure C-36. End-grain corrosion on Coupon V326 in Tank WM-182 (PD03-0029-08). ${ }^{10}$ 


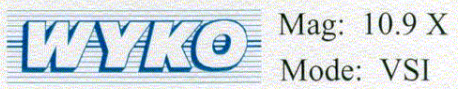

\begin{tabular}{l}
\hline Surface Statistics: \\
Ra: 7.92 um \\
Rq: $10.26 \mathrm{um}$ \\
Rz: $60.54 \mathrm{um}$ \\
Rt: $64.21 \mathrm{um}$ \\
Set-up Parameters: \\
Size: 736 X 471 \\
Sampling: 782.61 n \\
Processed Options: \\
Terms Removed: \\
Tilt \\
Filtering: \\
None
\end{tabular}

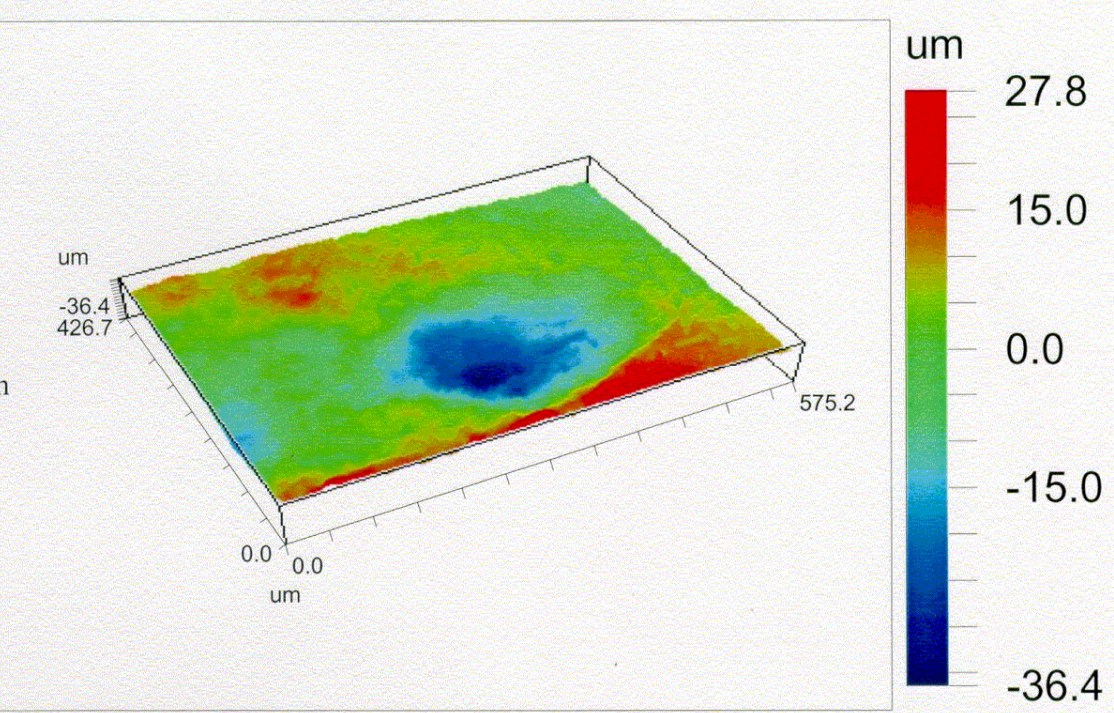

$-36.4$

Title: WM-182 V286

Note: ETCHED PIT

Figure C-37. Etched pit on Coupon V286 in Tank WM-182 (PD03-0029-09). ${ }^{10}$

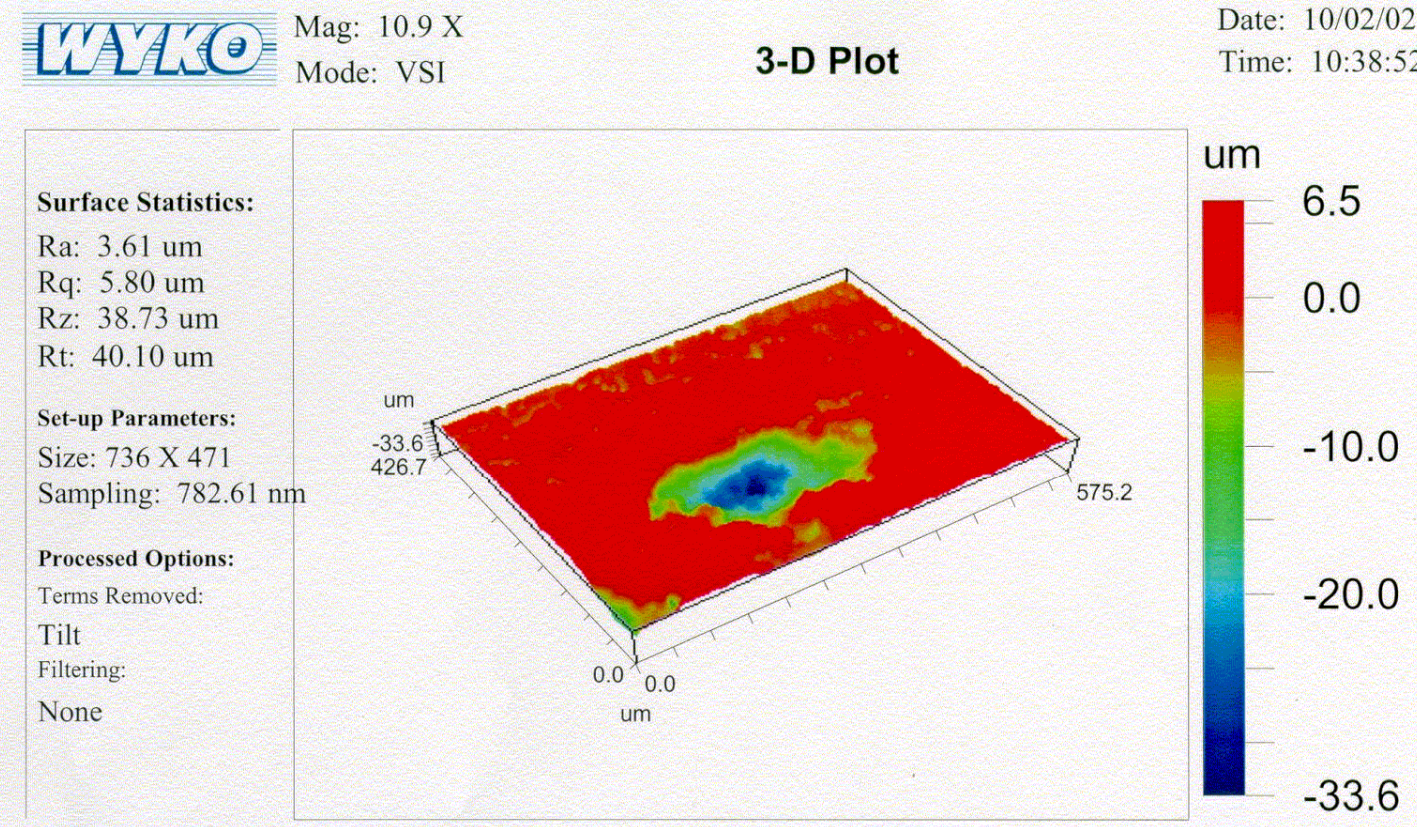

Title: WM-182 V306

Note: PIT

Figure C-38. Pit on Coupon V306 in Tank WM-182 (PD03-0029-10). ${ }^{10}$ 


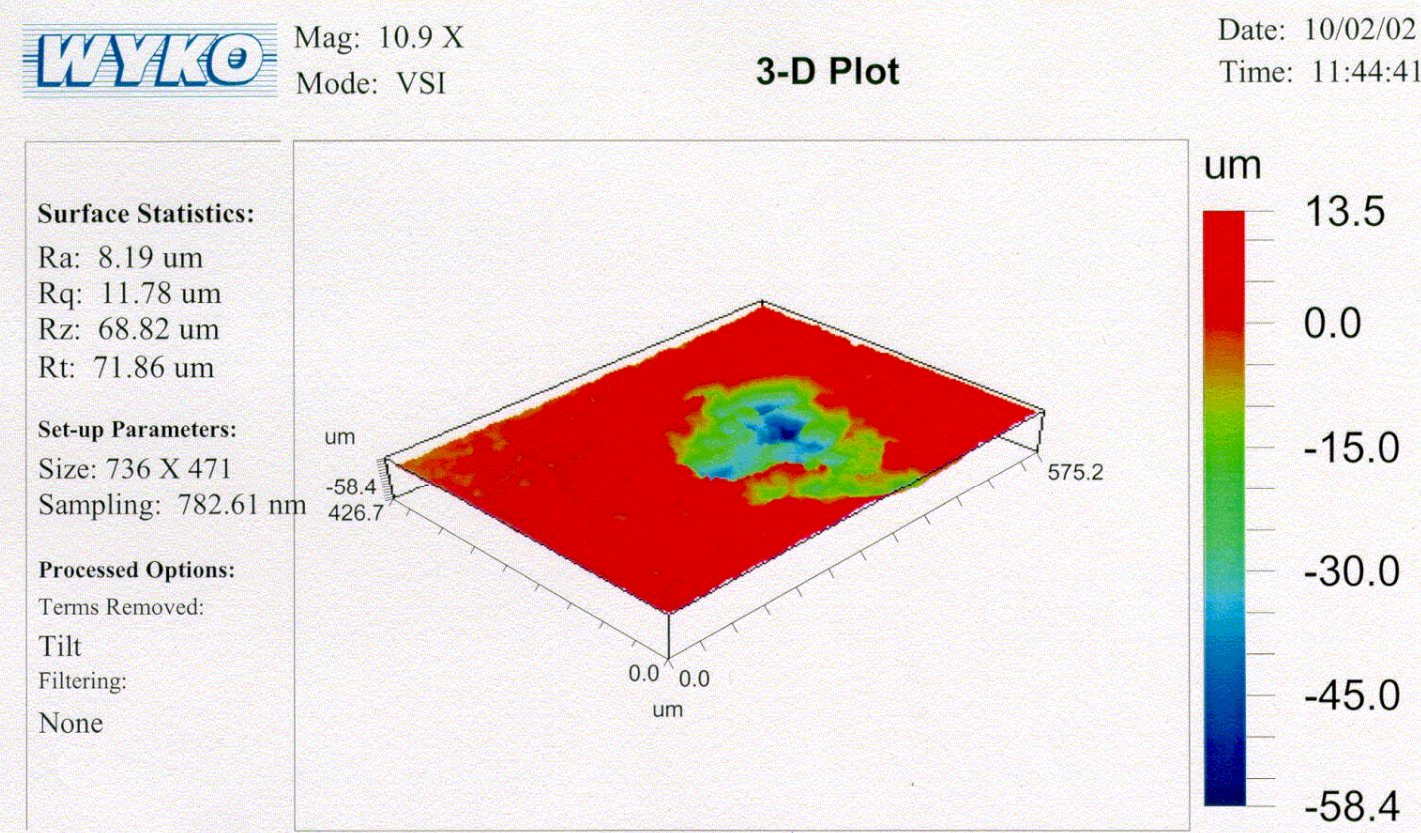

Title: WM-182 V329

Note: ETCHED PIT

Figure C-39. Etched pit on Coupon V329 in Tank WM-182 (PD03-0029-11). ${ }^{10}$

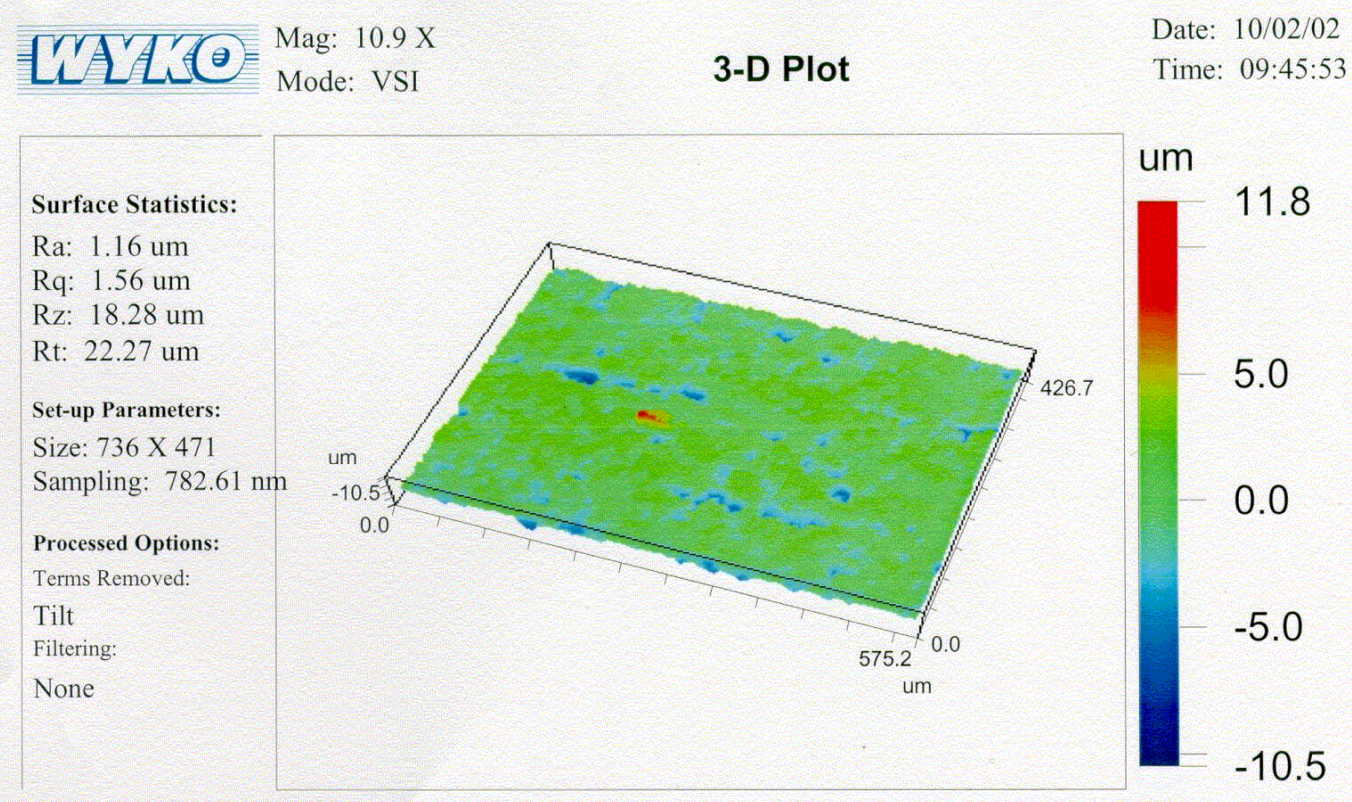

Title: WM-182 V326

Note: GENERAL CORR

Figure C-40. Interferometer scan showing general corrosion on Coupon V326 in Tank WM-182 (PD03-0029-12). ${ }^{10}$ 
Figure C-40 depicts an area on a Tank WM-182 coupon of typical general corrosion. The corrosion damage has been very light, and the surface roughness is not very different from the initial coupon surface. Most of the coupons retrieved have had this light general corrosion attack. However, a few coupons revealed an accelerated corrosion attack. Figures C-41 and C-42 show two examples of such an attack. The surface roughness is much worse than that shown in Figure C-40, which indicates typical general corrosion. The distance between the high and low spots is of the same magnitude as of the pits discussed earlier (see Figures C-37 through C-39). These areas of accelerated corrosion were found to occur in distinct localized areas. These areas are larger than the singular pits found earlier, but only encompass an area several millimeters in diameter. ${ }^{10}$

In conclusion, the reevaluation of Tank WM-182 indicates pit initiation. ${ }^{10}$ While some of the pits were similar to the etched pits in Tanks WM-187, WM-188, and WM-189, the corrosion in Tank WM-182 more closely resembled that seen in Tank WM-183. The initial report on Tank WM-182 mentioned pitting in the results section, but it did not emphasize it in either the summary or conclusion sections. ${ }^{7}$ Any future references to Tank WM-182 should indicate pit initiation was first determined from the 1999 coupon retrieval.

Historically, an area of concern has been the bottom of the tanks where accumulated solids could potentially accelerate uniform corrosion rates or localized corrosion. ${ }^{3}$ However, examination in 1999 of the five welded tank coupons placed on the bottom of Tank WM-182 in 1988 revealed no increase in uniform corrosion rates and no localized corrosion (see Figure C-4). Moreover, the lowest corrosion rates observed were in the coupons retrieved from the bottom of the tank. ${ }^{7}$

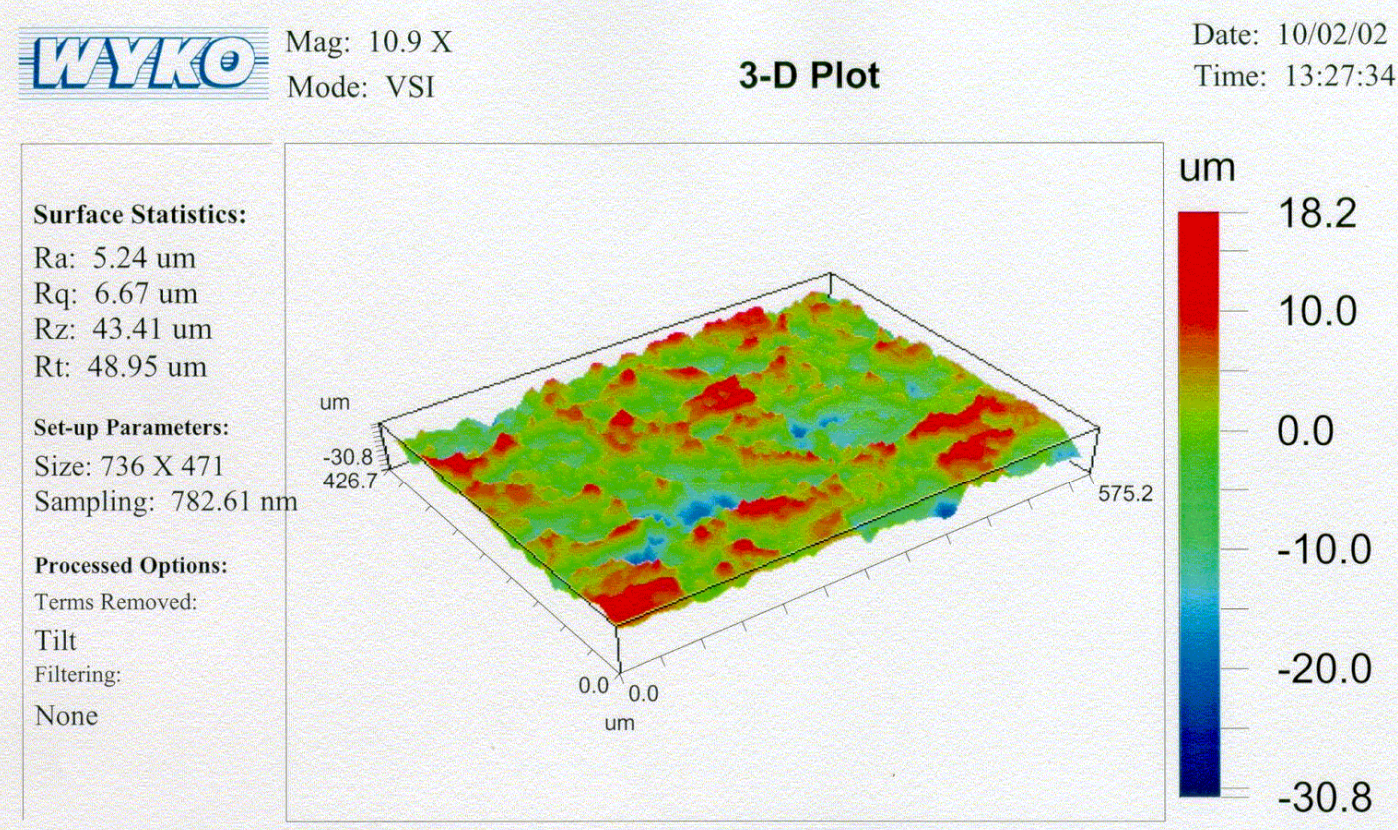

Title: WM-182 V279

Note: GENERAL ATTACK

Figure C-41. Interferometer scan showing accelerated general corrosion attack on Coupon V279 in Tank WM-182 (PD03-0029-13). ${ }^{10}$ 


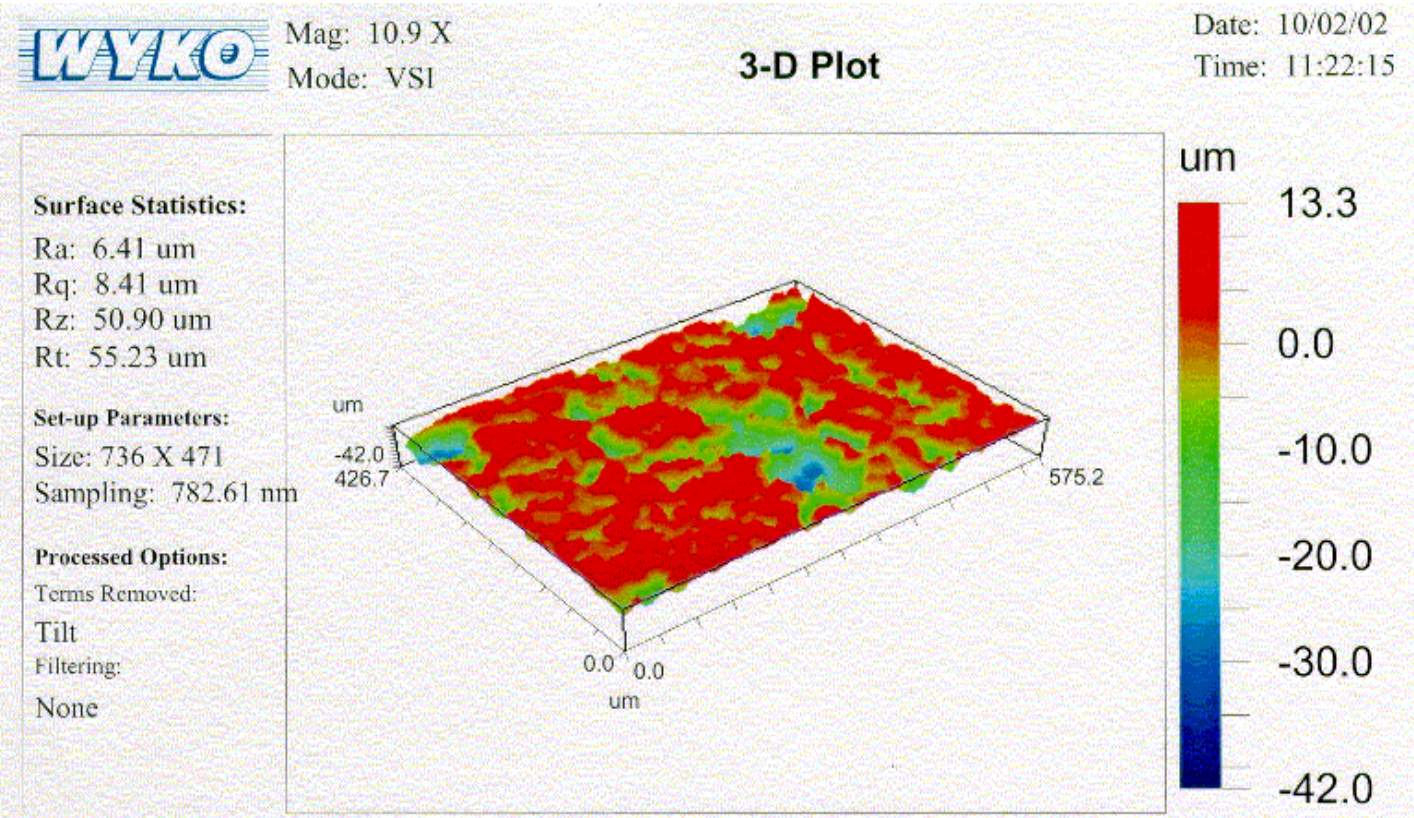

Title: WM-182 V326

Note: ATTACK

Figure C-42. Accelerated general attack on Coupon V326 in Tank WM-182 (PD03-0029-14). ${ }^{10}$

Remaining corrosion coupons were removed from WM-180, WM-181, WM-184, WM-185, and WM-186 at the time of tank washing, and were placed in storage without decontamination or examination. They are located in a cargo container in the TFF. The corrosion coupons were removed as follows:

WM-185: June 19, 2003

WM-186: July 28, 2003

WM-184: November 12, 2003

WM-181: March 9, 2004

WM-180: Approximately August 4, 2004 (the exact date was not documented).

The tanks have been RCRA closed and these coupons will probably be discarded unless funds are identified for evaluation.

\section{C6. SUMMARY OF IN-TANK CORROSION COUPON DATA}

A summary of TFF corrosion information available from all previous reports is presented in Table 1, found in the main body of this report. ${ }^{1-3,5,7-10}$ The general corrosion rates shown in the table are averages calculated for the test coupons removed from the waste tanks, based on weight loss from the coupon, except for the 1962 data, which are maximum corrosion rates. ${ }^{1}$ In addition, the metal loss data, based on the average general corrosion rate and the length of time a tank has been in use, are presented. The corrosion rates are generally higher for the first period of exposure, which may be related to accelerated corrosion of a freshly exposed metal surface or possibly to the use of only maximum corrosion rates for the 1962 report data. 


\section{C7. REFERENCES}

1. Hoffman, T. L., Corrosion Evaluation of Stainless Steels Exposed in ICPP High-Level Radioactive Waste Tanks, IDO-14600, Atomic Energy Commission, Idaho Operations, Idaho Falls, Idaho, December 1962.

2. Hoffman, T. L., Corrosion Evaluation of Stainless Steels in ICPP High-Level Radioactive Waste Service, ICP-1072, Idaho National Engineering Laboratory, Allied Chemical Corporation, Idaho Falls, Idaho, June 1976.

3. Zimmerman, C. A., Corrosion Evaluation of ICPP High-Level Liquid Waste Storage Tanks, WINCO-1064, Idaho National Engineering Laboratory, Westinghouse Idaho Nuclear Company, Idaho Falls, Idaho, April 1989.

4. Patterson, M., Light Duty Utility Arm Deployment in Tank WM-188, INEEL/EXT-99-01302, 2001 Idaho National Engineering and Environmental Laboratory, Bechtel BWXT Idaho, LLC, Idaho Falls, Idaho, December 1999.

5. Hoffman, T. L., B. C. Norby, R. E. Mizia, and C. A. Zimmerman, Evaluation of Stainless Steel Tank Corrosion in ICPP High Level Radioactive Waste Service, ENICO-1131, Idaho National Engineering Laboratory, Exxon Nuclear Chemical Company, Idaho Falls, Idaho, April 1983.

6. Advanced Engineering Consultants, Addendum to Chapter 4 of "Seismic Analysis and Evaluation of Waste Tank Vaults WM-180 \& WM-181 and WM-187 Through WM-190 at the Idaho Chemical Processing Plant, Idaho National Engineering Laboratory, San Francisco, March 1993.

7. Dirk, W. J., and P. A. Anderson, Corrosion Evaluation of INTEC Waste Storage Tank WM-182, INEEL/EXT-99-01109, Idaho National Engineering and Environmental Laboratory, Bechtel BWXT Idaho, LLC, Idaho Falls, Idaho, November 1999.

8. Dirk, W. J. and L. L. Torres, Corrosion Evaluation of INTEC Waste Storage Tank WM-183, INEEL/EXT-01-00262, Idaho National Engineering and Environmental Laboratory, Bechtel BWXT Idaho, LLC, Idaho Falls, Idaho, March 2001.

9. Yoder, T. S. and B. C. Norby, Corrosion Evaluation of INTEC Waste Storage Tanks WM-187, $W M-188, W M-189$, and $W M-180$, INEEL/INT-02-01150, Idaho National Engineering and Environmental Laboratory, Bechtel BWXT Idaho, LLC, Idaho Falls, Idaho, September 2002.

10. Yoder, T. S., to J. W. Bryant, "Re-Evaluation of Tank WM-182 Corrosion Coupons," TSY-06-02, October 30, 2002. 
C-38 
Appendix D

\section{Tank Inspections}


D-2 


\section{Appendix D}

\section{Tank Inspections}

\section{D1. EARLY VISUAL INSPECTIONS}

A history of early visual inspections that have been performed on the nominal 300,000-gal tanks at the Tank Farm Facility (TFF) is presented in this appendix.

Several visual inspections of the 300,000-gal tanks have been performed over the years. In 1994, a summary videotape of these inspections was prepared, and the inspection results are described below. ${ }^{1}$

On November 18, 1983, solids sampling was performed in Tank WM-185, with a video camera used to monitor the sampling operation. Cooling coils that were visible appeared to be in good condition. About $5 \mathrm{~cm}$ ( 2 in.) of solids were observed on the tank bottom. Photos for weld inspection were taken using a 35-mm camera, but were fogged over and inconclusive. ${ }^{1}$

On November 4, 1985, video footage was taken of air sparge stirring of heel solids in Tank WM-188. Visible cooling coil piping appeared to be in good condition.

In October 1986, Tanks WM-187, 188, and 189 were examined for corrosion problems using a video camera. The evaluation of the pictures was inconclusive. ${ }^{2}$

On July 7, 1987, a wash down of Tank WM-187 was performed and videotaped. Solids on the walls were easily removed, and grind marks from original construction were clearly visible. No corrosion was apparent at the liquid-gas interface. In August 1987, a wash down of Tanks WM-188 and WM-189 was performed and videotaped. Solids were easily removed from the tank walls and piping. Again, no corrosion was apparent at the liquid-gas interface. Inspection of the tank bottoms was not possible at that time due to the liquid in the tanks. ${ }^{3}$

In July 1990, the radio frequency probes from Tanks WM-180 and WM-181 were removed and inspected for corrosion, then returned to the tanks. Slight discoloration was evident in the heat-affected zone of a weld, but no visible problems with the weld were apparent. No corrosion was evident at the liquid-surface interface or elsewhere on the probe. ${ }^{1}$

\section{D2. 1999 VISUAL EVALUATION OF TANK WM-188}

To facilitate understanding of the images captured from the video 1999 inspection, the construction practices followed for the tanks are reviewed below. All of the 300,000-gal tanks were fabricated out of rolled stainless steel plates that were welded together. Figure D-1 shows an early construction view of Tank WM-188, in which the tank bottom and one row of the wall shell course have been installed. The horizontal and vertical edges of the plates where they were welded together are an obvious feature. Support structures for work platforms were welded to the tank wall, but these supports were later removed. Figure D-2 shows the process at a later stage, with grinding marks visible on the metal surfaces of the first row of metal plates where the supports were removed. Figure D-3 shows the installation of cooling coils in Tank WM-187. All of the supports that were attached to the walls have been removed. Extensive grinding marks are evident on the tank walls. ${ }^{4}$ 


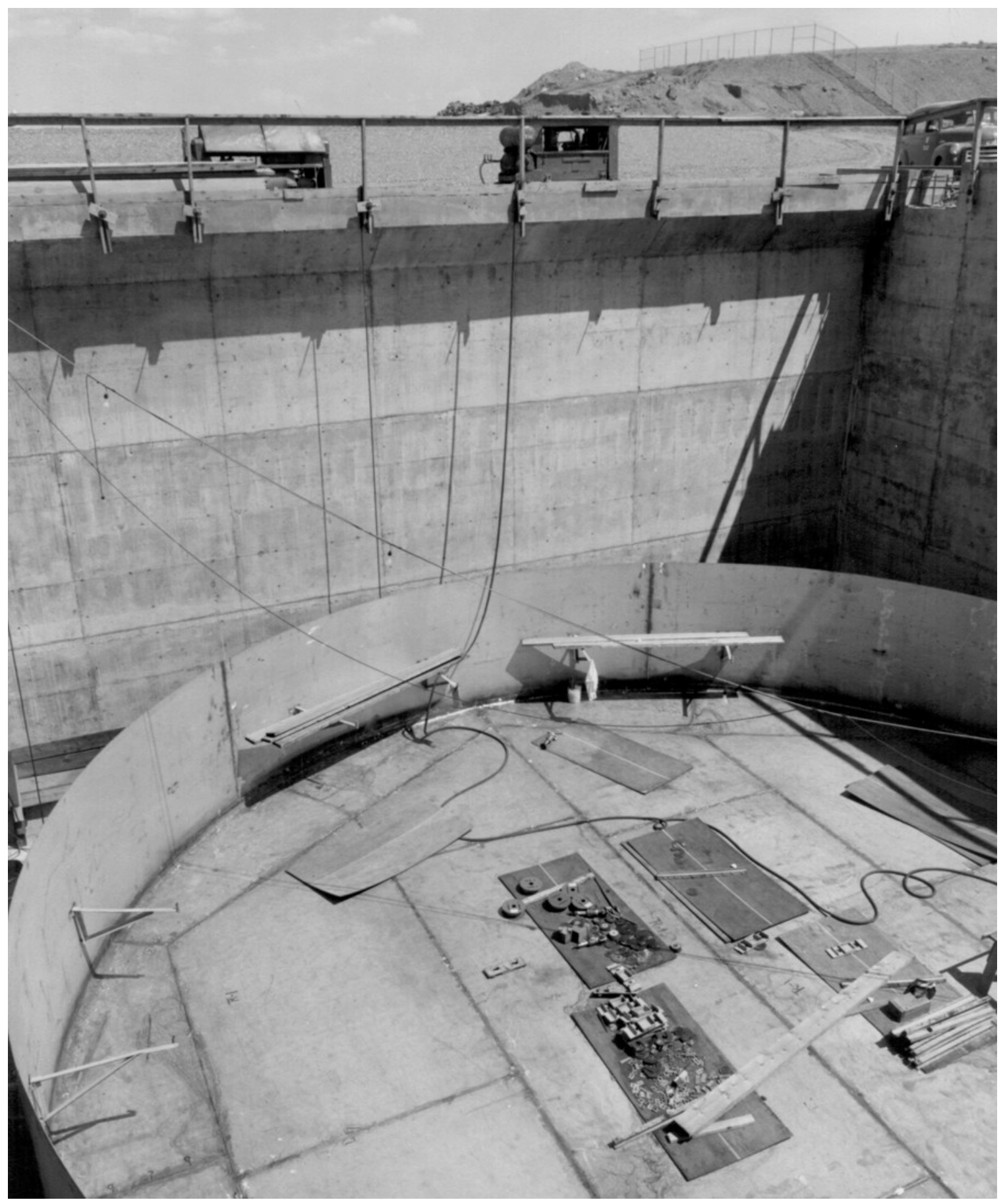

Figure D-1. Construction of Tank WM-188 (58-3473). 


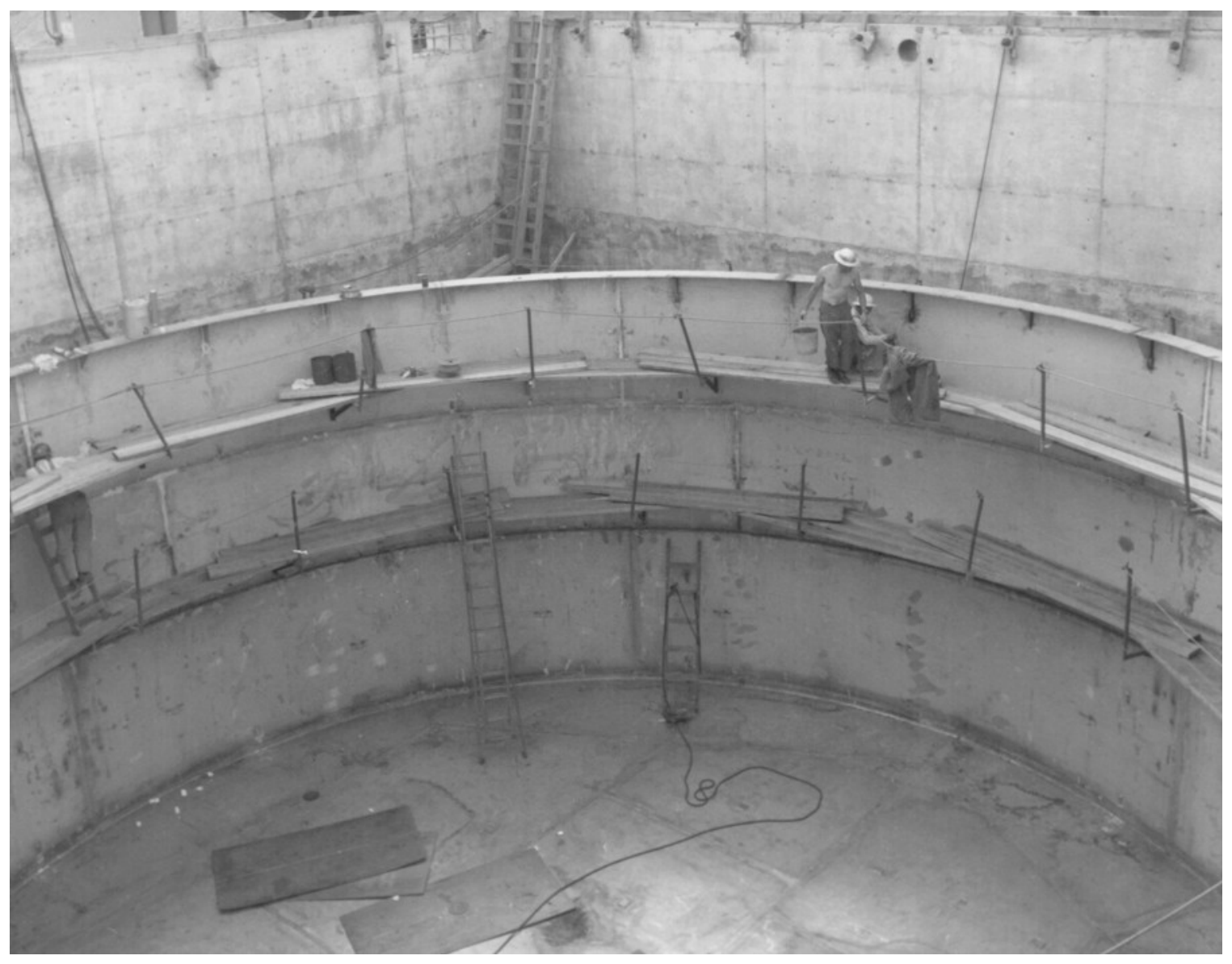

Figure D-2. Later stages of construction of Tank WM-188 (58-4236). 


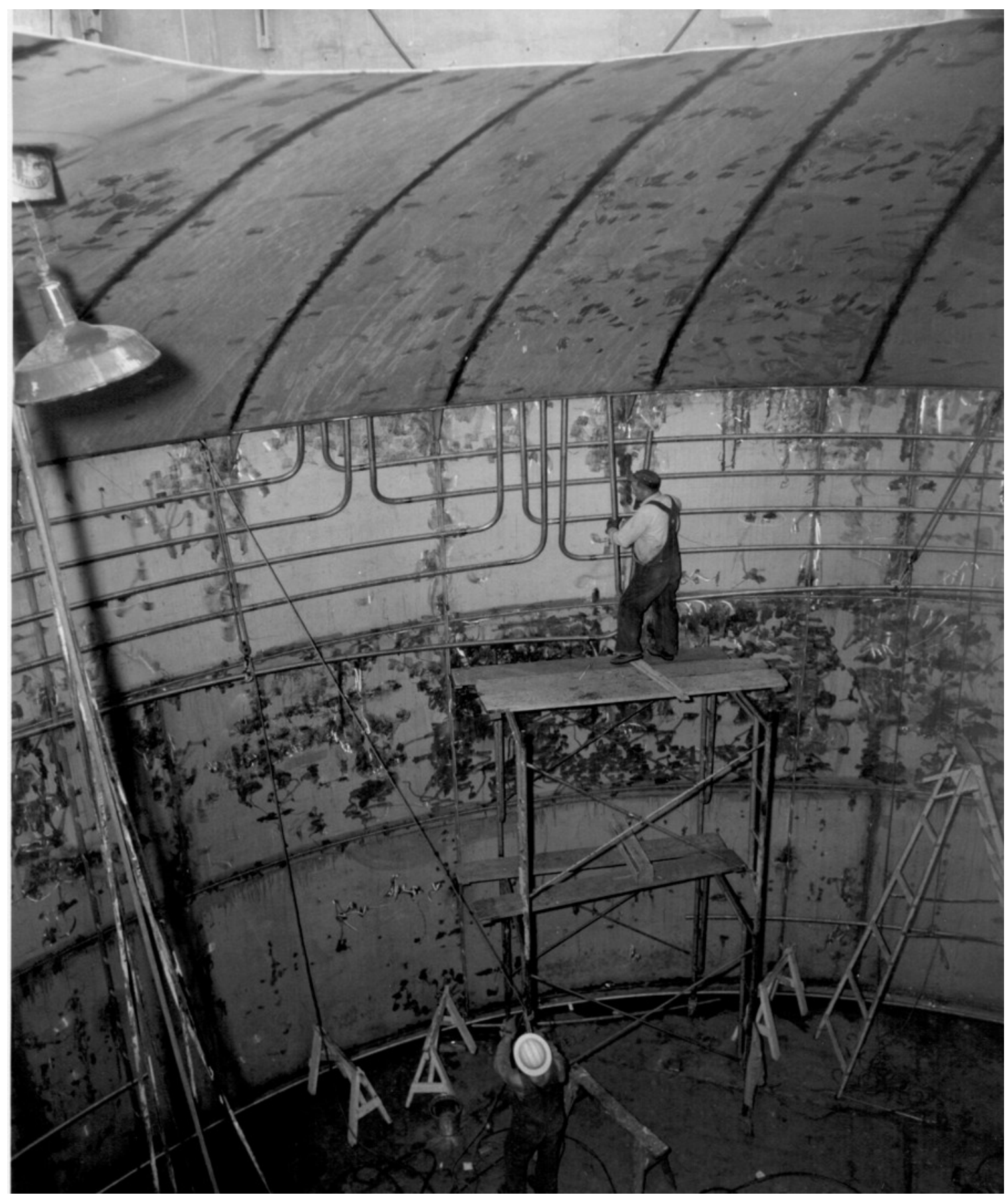

Figure D-3. Installation of cooling coils for Tank WM-187 (58-4237). 
In February 1999, a high-resolution stereo video system end effector was deployed into Tank WM-188 by the remote light duty utility arm (LDUA) to inspect the interior of the tank. ${ }^{4}$ Video photographs shown in Figures D-4 through D-6 were taken using this system. ${ }^{4}$ The inspection concentrated on accessible areas containing welds that are considered the most likely areas for the initiation of localized corrosion. The inspection technique was to scan the walls for visual evidence of localized corrosion. The intersection of two welds of a typical weld area is shown in Figure D-4. This area would be exposed to high heat input from the intersecting welds that will increase susceptibility to intergranular corrosion. The weld joint area also would be an area of high residual tensile stress. No evidence is indicated of intergranular corrosion or cracking in the weld heat-affected zone within the limitations of the camera resolution and lighting techniques. Black spots on the surface of the weld and base metal appear to be surface deposits, but this cannot be confirmed with a two-dimensional inspection technique. The shiny area to the left of the weld intersection appears to be a grinding mark from the original fabrication.

Figure D-5 shows a horizontal weld with indentations in the plate next to the weld. The indentations are believed to be marks where a mechanical lifting device was fastened to the plate, as shown in Figure D-6. Other spots on the surface are shown that cannot be measured for convexity or concavity because the two-dimensional video image could not be interpreted.

The tank walls and internal cooling coils of Tank WM-188 were covered with surface deposits, as shown in Figure D-7. The first deposit shows up as a lighter tone of gray in the video. It covers much, but not all, of the top surfaces of the stainless steel cooling coils. A second type of black deposit appears on top of all surfaces in the tank as shown in Figure D-7. No crevice corrosion of the pipe surface or weld from these deposits is evident. The weld appears to have the proper crown and no evidence is indicated of a higher corrosion rate for the weld or the weld heat-affected zone. ${ }^{4}$

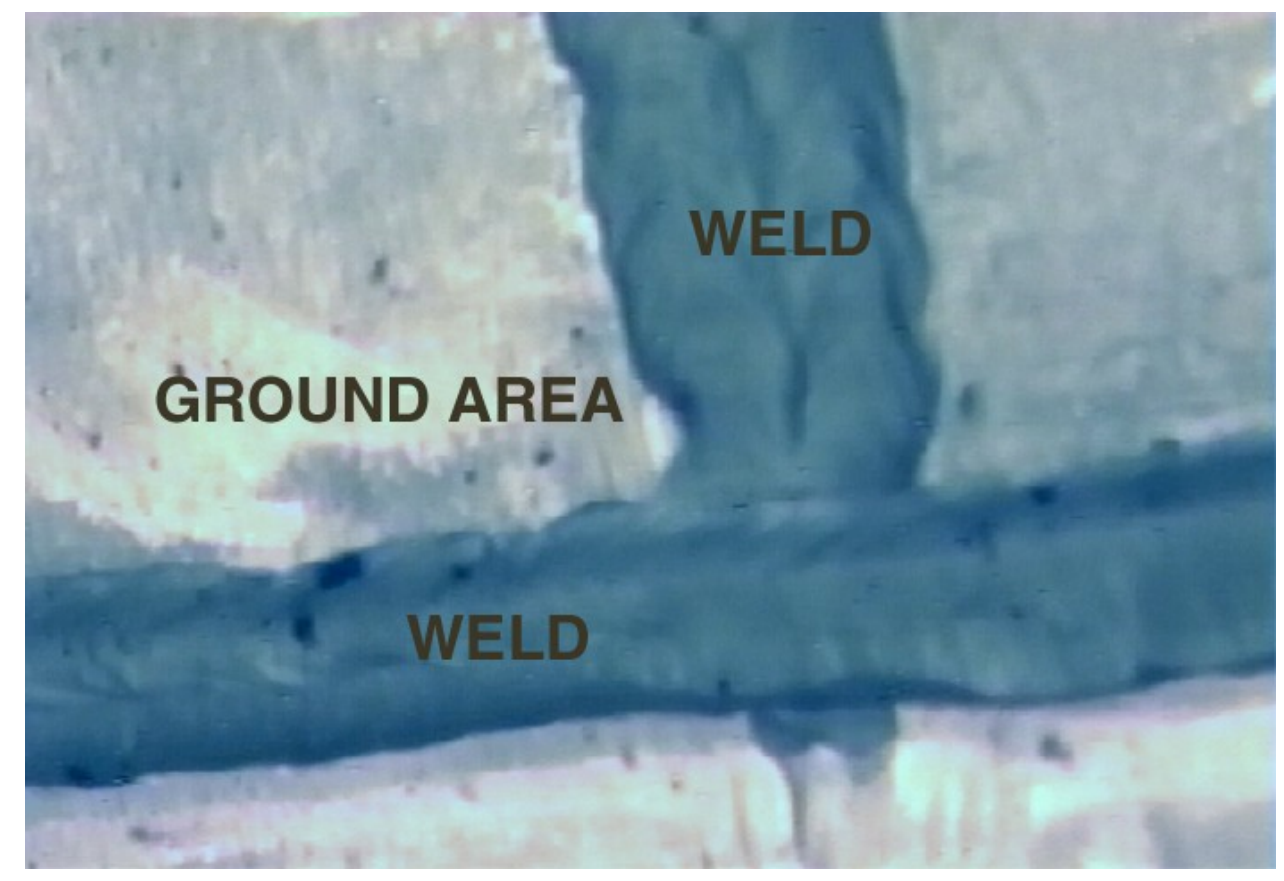

Figure D-4. Weld intersection in Tank WM-188 (PD03-0029-05). ${ }^{5}$ 


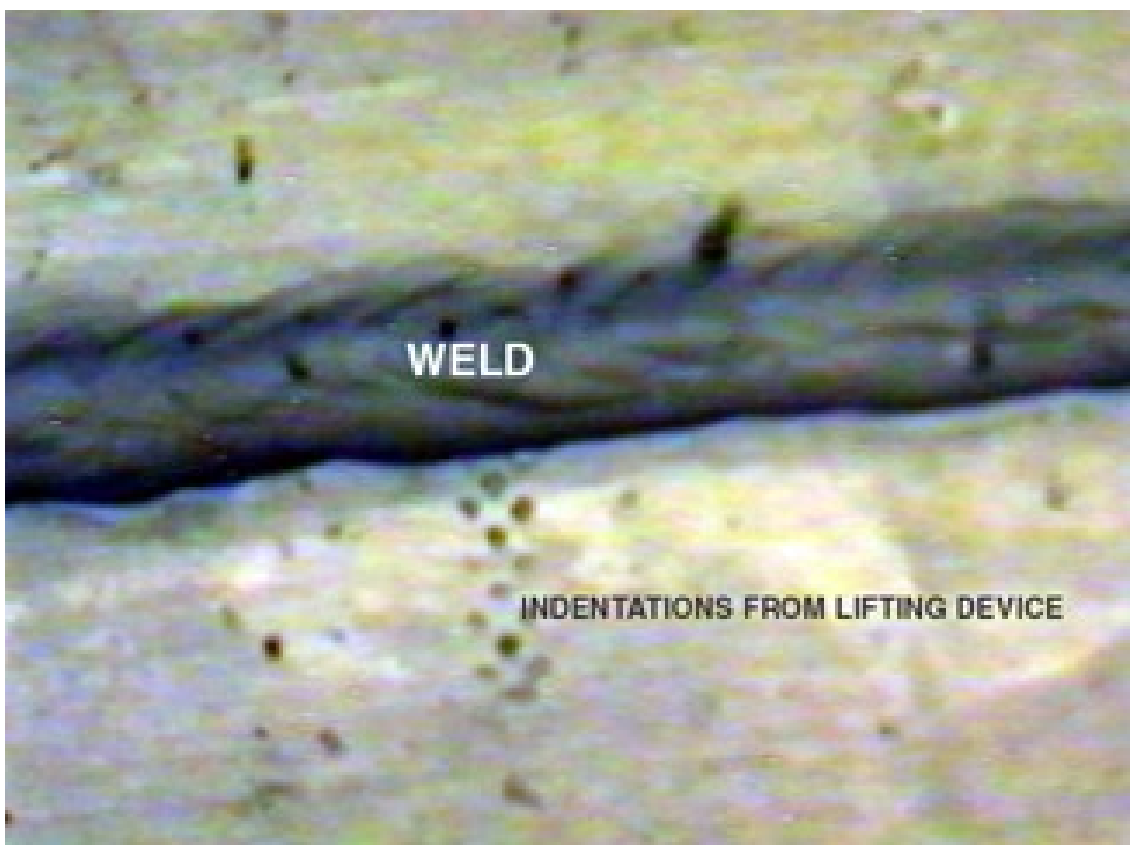

Figure D-5. Areas of mechanical damage from initial tank construction (PD03-0029-06). ${ }^{5}$

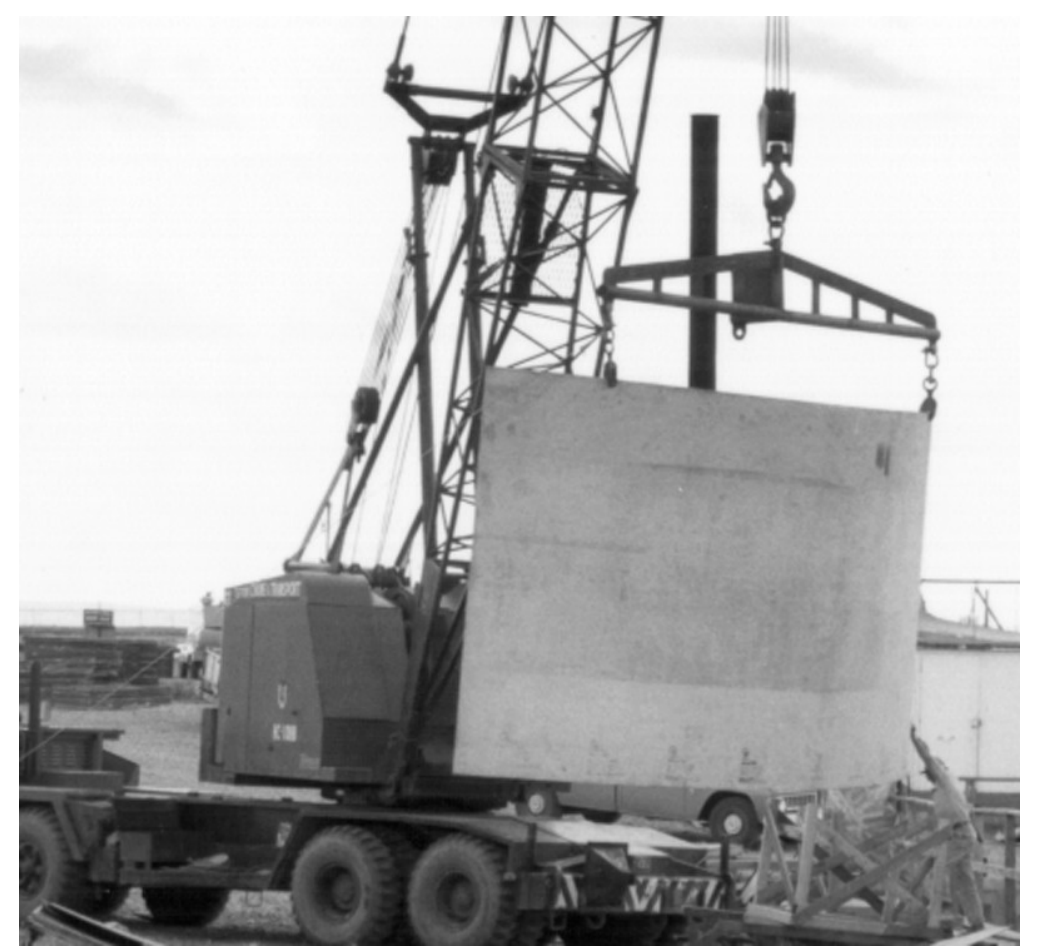

Figure D-6. Hoisting of plate section showing lifting device (63-6763). ${ }^{5}$ 


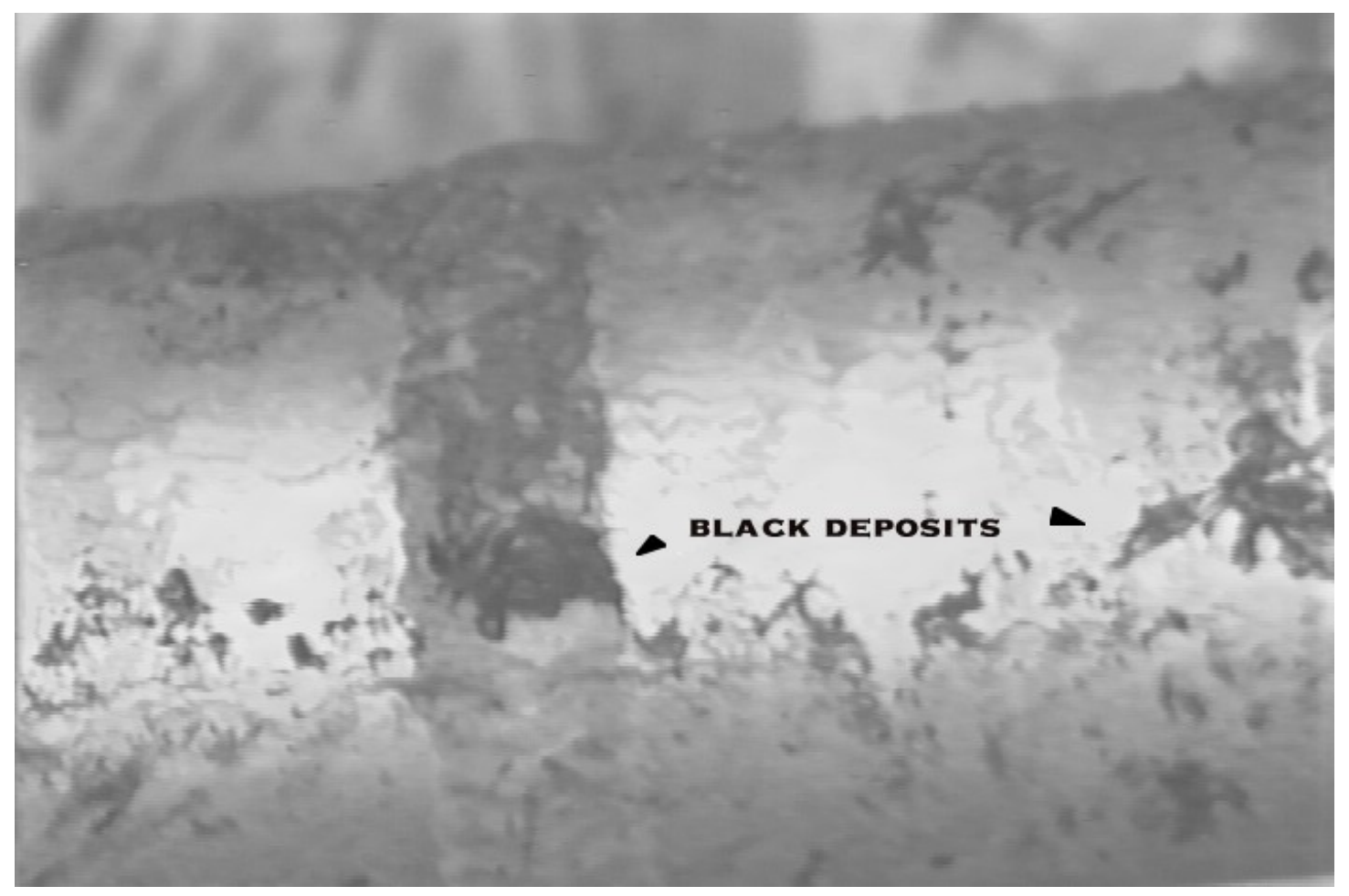

Figure D-7. Cooling coil pipe surface with deposits (PD03-0029-07). ${ }^{5}$

\section{D2.1 Summary of 1999 Visual Evaluation of Tank WM-188}

In summary, a review of the video from the LDUA inspection of WM-188 shows no evidence of localized corrosion of the Type 304L stainless steel tank walls, welds, or weld heat-affected zones. Areas of localized mechanical damage from the initial construction of this tank did not act as localized corrosion initiation sites. Deposits of material were present on the tank walls, but no areas of corrosion associated with the deposits were apparent. Areas are present in which the two-dimensional video image could not be interpreted as to whether it was convex or concave.

Based on the examination of the inspection video for Tank WM-188, the internal wall surfaces and welds of Tank WM-188 are concluded to be in good condition with no visible evidence of localized corrosion at the resolution of the video system. ${ }^{4}$

\section{D3. 1999 NONDESTRUCTIVE EXAMINATION EVALUATION OF WM-188}

An alternating current field measurement end effector was deployed and tested in WM-188 using the LDUA. The alternating current field measurement end effector detects and measures cracks, wall thickness, and pits in stainless steel walls and tank wells. The resolution of the end effector for cracks is $1.27 \mathrm{~cm}$ (0.5 in.) long and $0.65 \mathrm{~cm}(0.25 \mathrm{in}$.) deep. For pits the resolution is $0.65 \mathrm{~cm}(0.25 \mathrm{in}$.) in diameter and $0.65 \mathrm{~cm}(0.25 \mathrm{in}$.) deep. The system was used to scan some visible construction defects on the side of the tank, but they were too small to be detected. Further development would be necessary to improve the precision of the system for application in the TFF. ${ }^{4}$ 
A separate nondestructive examination (NDE) end effector employing continuous wave eddy current sensors was specifically designed to find corrosion pitting and cracking near welds and in base material. The NDE end effector design allowed for its placement above the liquid for inspecting the tank wall. Design modification could allow the end effector to be submerged in a liquid or semiliquid, but it is questionable whether it could be modified to operate in acidic SBW solution. The NDE end effector and data acquisition system were laboratory bench tested on welded stainless steel plates fabricated to reflect the condition of walls and flooring in underground storage tanks at INTEC. Machined holes (to simulate pits) and actual thermal fatigue cracks adjacent to the welds were used to assess detection and sizing capability. Hole sizes down to $0.15 \mathrm{~cm}(0.06$ in.) in diameter and $0.07 \mathrm{~cm}(0.028 \mathrm{in}$.) in depth, along with cracks as small as $1.27 \mathrm{~cm}(0.5 \mathrm{in}$.$) in length and 0.2 \mathrm{~cm}(0.08 \mathrm{in}$.$) in depth, were easily detected with$ signal-to-noise ratios exceeding 20:1. The end effector was planned to supplement visual inspections, not to be a stand-alone inspection system.

The NDE end effector was installed for a short period of time on the LDUA in a testing facility at INTEC. During initial functional tests, electronic noise generated by the arm and its power supply system degraded the eddy current signals. Operational amplifiers were subsequently installed in the device to determine whether signal strength could be adjusted in this manner. However, the LDUA was being installed in Tank WM-188 by that time and no further testing could be performed. Subsequently, no project funds were available to test the NDE end effector and ensure that signal responses were sufficient to allow detection of flaws while it was installed on the LDUA.

Deploying the NDE end effector in a tank would require some initial effort to reassemble it on a functioning LDUA, perform functional tests, and correct any minor problems to make the system durable prior to actual use.

Several technical challenges also must be addressed before NDE can be performed, however. The most significant challenge for the system is to isolate noise from the LDUA and simultaneously maintain an adequate eddy current signal. In addition, the LDUA is currently inoperable with circuit board problems and batteries that must be repaired or replaced. Furthermore, personnel originally associated with the technical details for the LDUA and NDE end effector are no longer located at the INTEC, increasing the difficulty and expense of future deployment efforts. If all of these challenges could be resolved, the potential benefit of performing a baseline scan of the tanks would still be limited because the tanks will be out of service before a follow-up scan could be performed for comparison.

\section{D4. RESULTS OF 2001 AND 2002 VIDEO INSPECTIONS}

A camera video inspection of Tank WM-187 was performed on April 24, 2002. The inspection identified no evidence of corrosion on the tank walls or cooling coil piping. The surfaces of the tank wall and cooling coil piping were covered with a thin film of material. Dark material, similar to the residuals seen in Tank WM-188 in 1999 was found on the walls and cooling coil pipe. Welds on both the tank wall and piping were visible. The depth of solids on the floor varied from approximately 7.6 to $17.8 \mathrm{~cm}(3$ to $7 \mathrm{in}$.), with an estimated average of $10 \mathrm{~cm}$ (4 in.). ${ }^{6}$ Corrosion program personnel viewed the videos for Tanks WM-187, and WM-188 and did not identify any areas of concern. ${ }^{7}$

\section{D5. RESULTS OF 2003 AND 2005 VIDEO INSPECTIONS}

Camera inspections were conducted in Tanks WM-180 through WM-186 following tank washing as part of tank closure preparations. Although there was a small amount of solids in the tanks, no evidence of corrosion was observed in these tanks. Corrosion program personnel viewed the videos for Tanks WM182 , and WM-183 and did not identify any areas of concern. ${ }^{7}$ 
Photos D-8 through D-14 were taken from inspection videos and are provided to show a portion of the bottom of each tank.

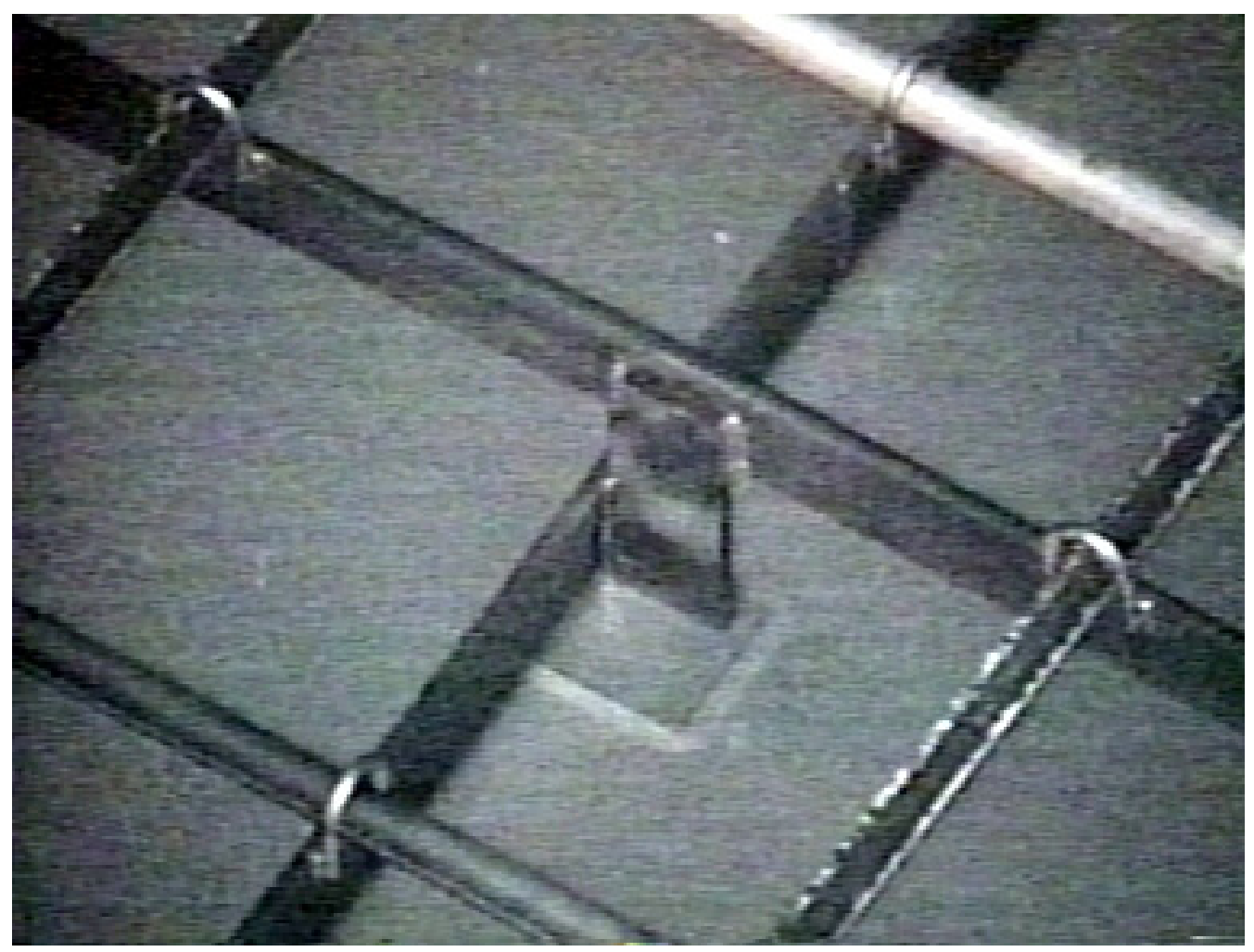

Figure D-8. WM-180 cooling coils and support. 


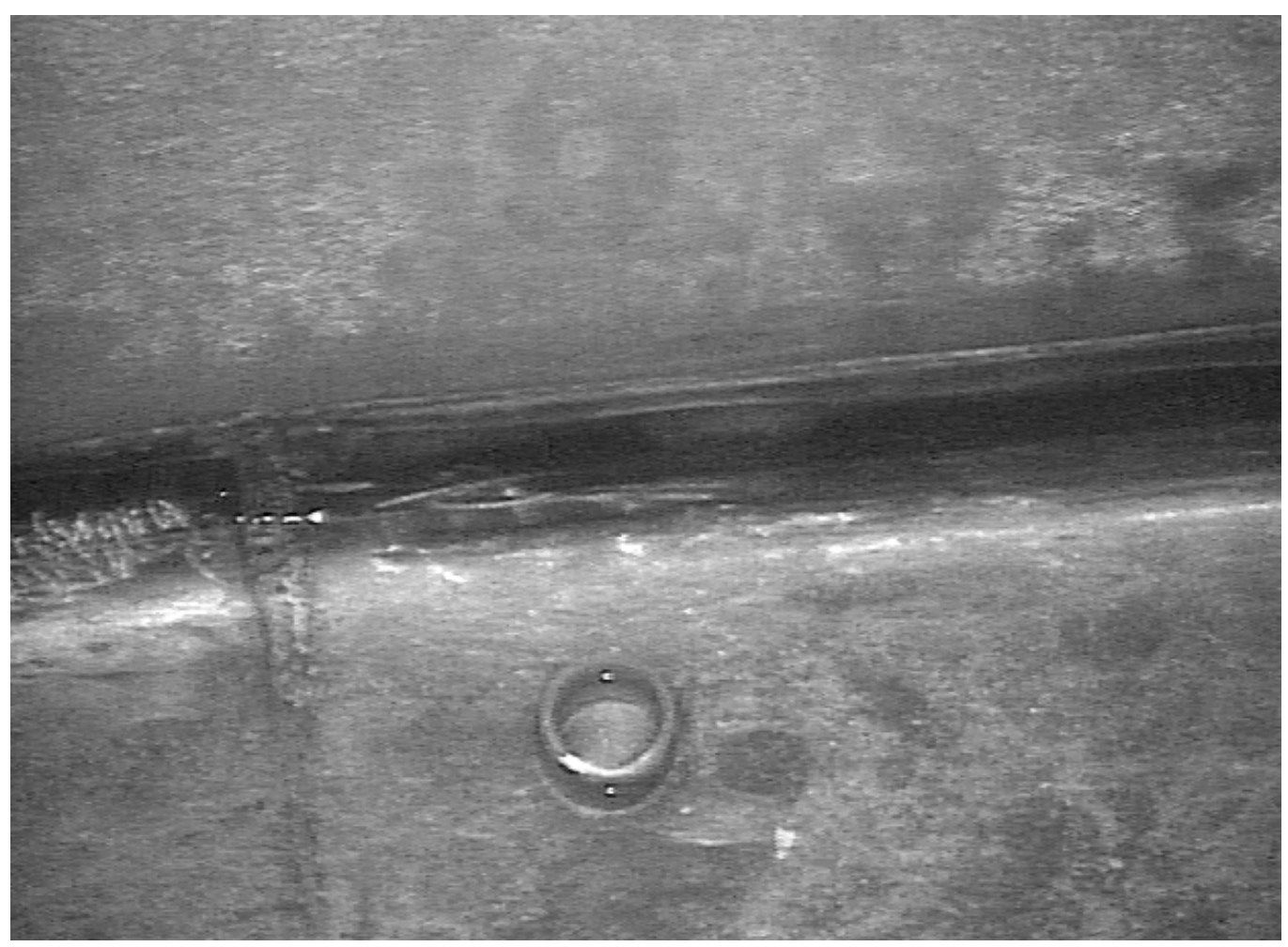

Figure D-9. WM-181 bottom and side with corrosion coupon.

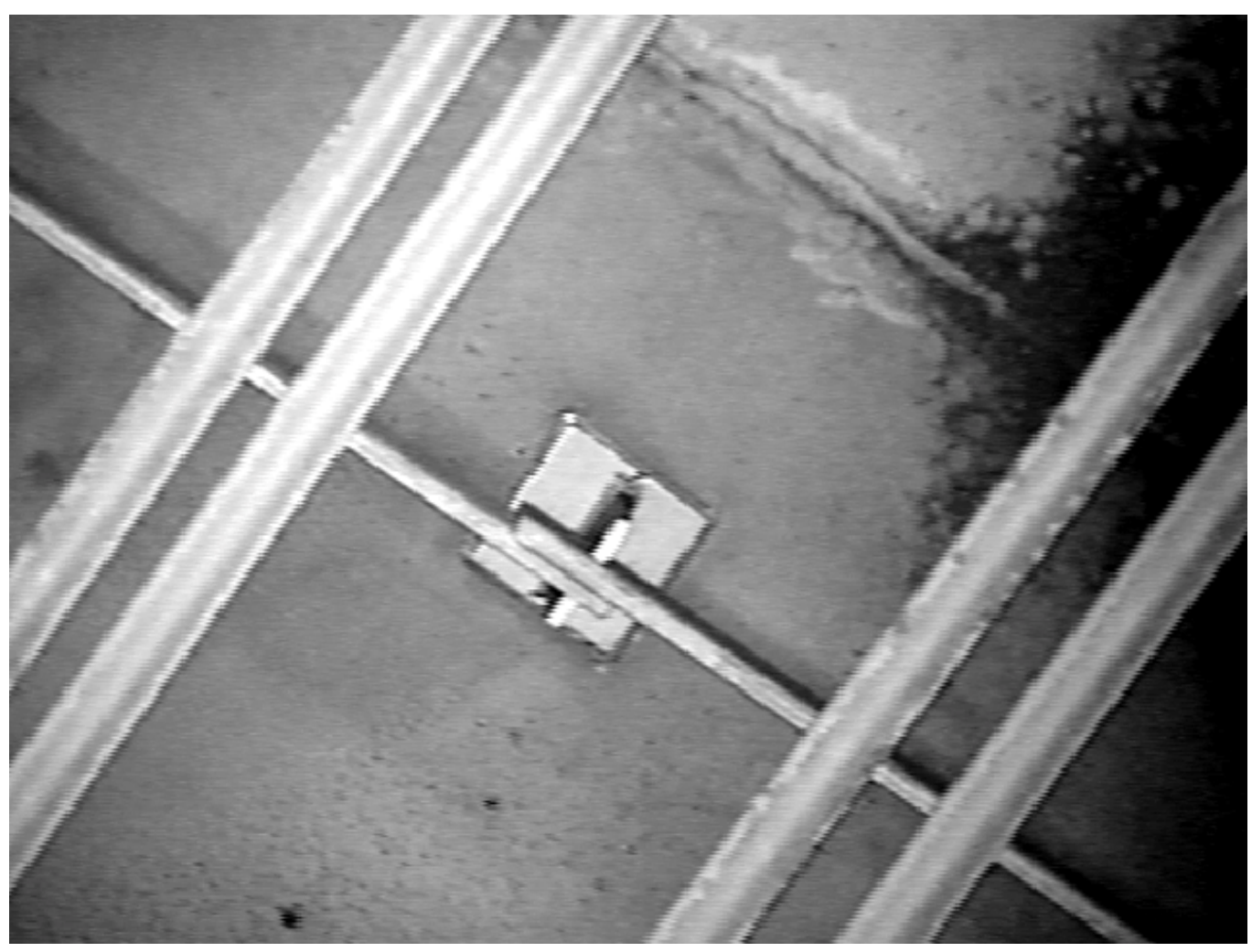

Figure D-10. WM-182 cooling coils, support and plate weld. 


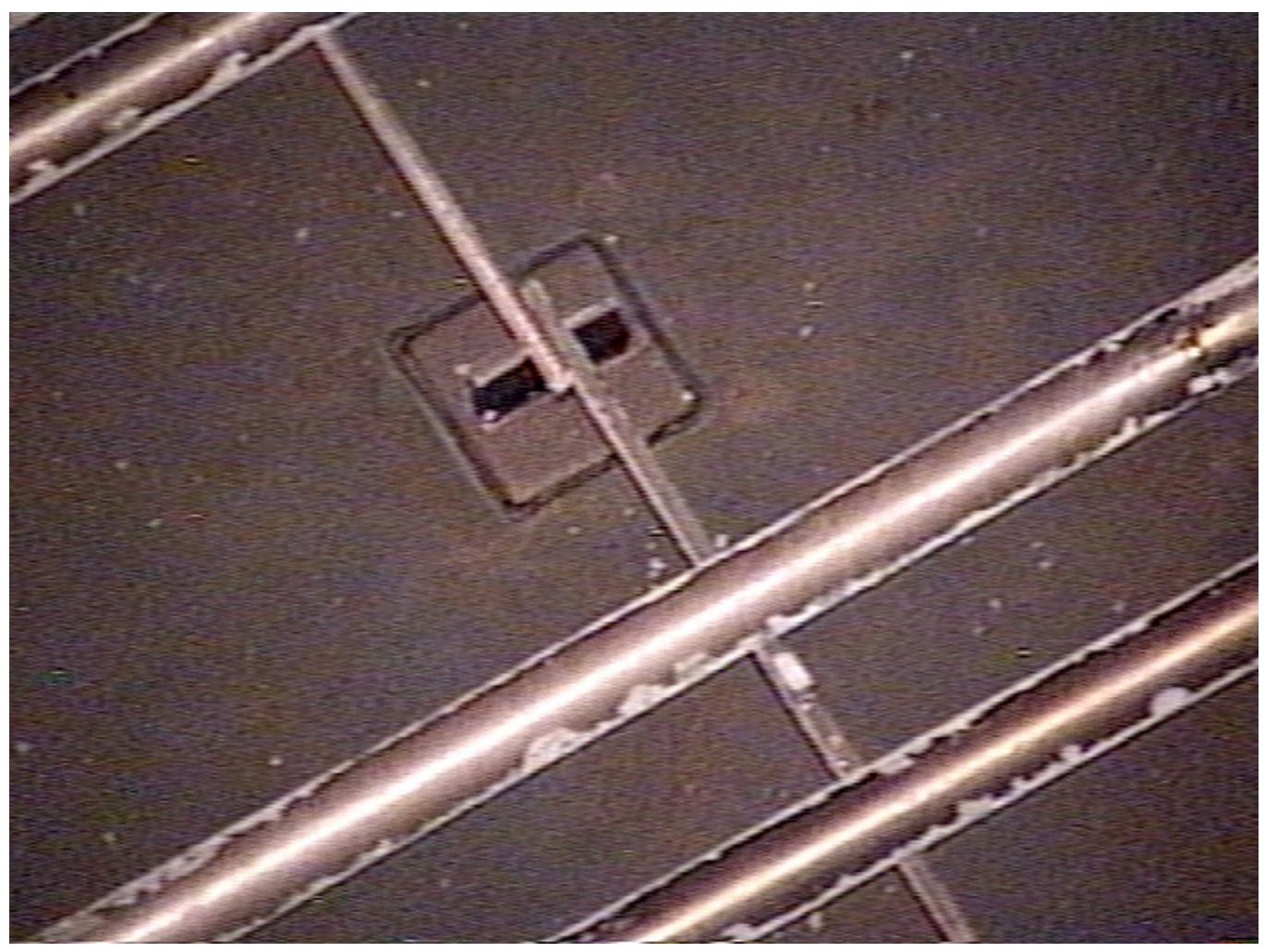

Figure D-11. WM-183 cooling coils and support.

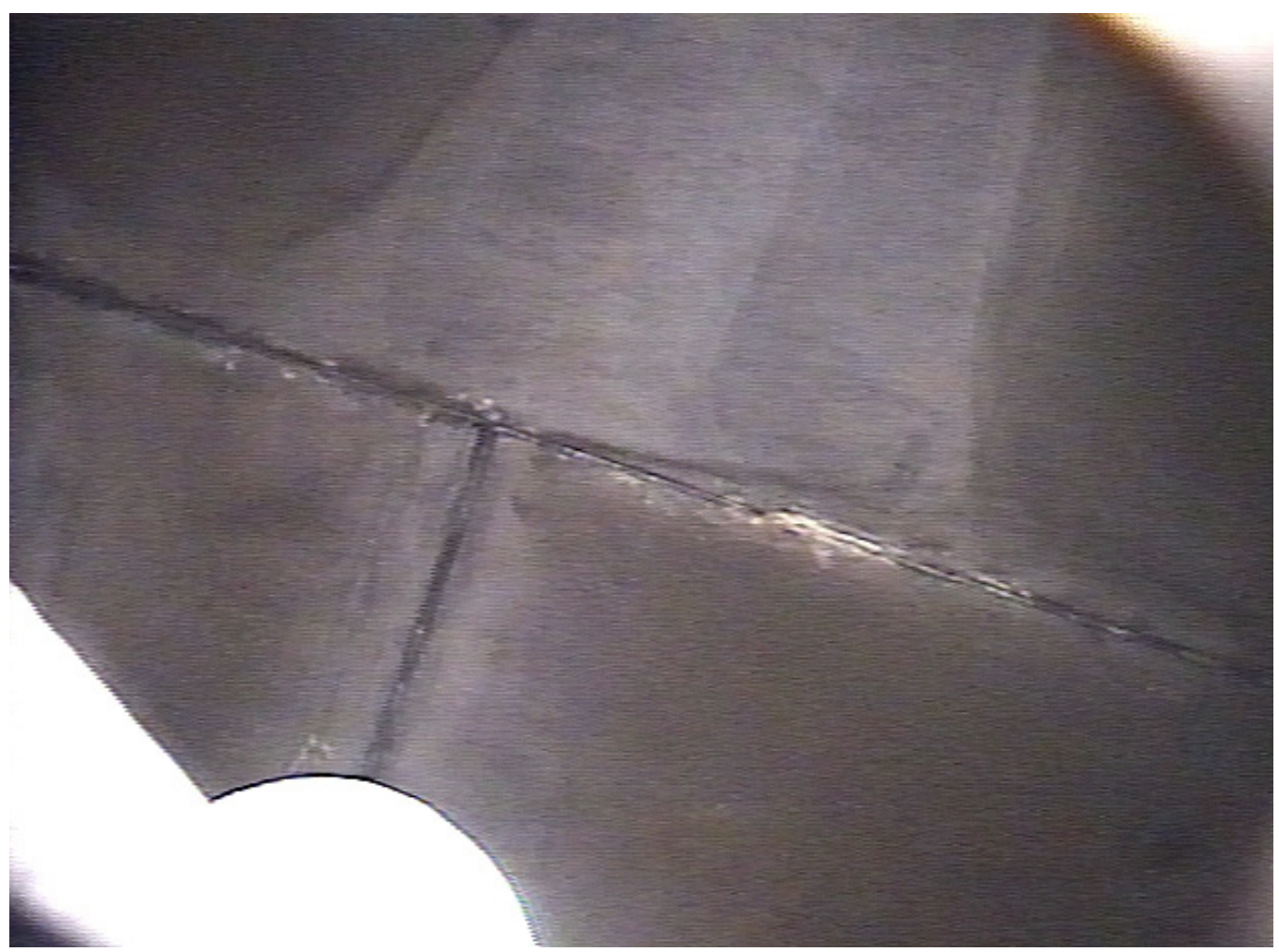

Figure D-12. WM-184 bottom welds. 


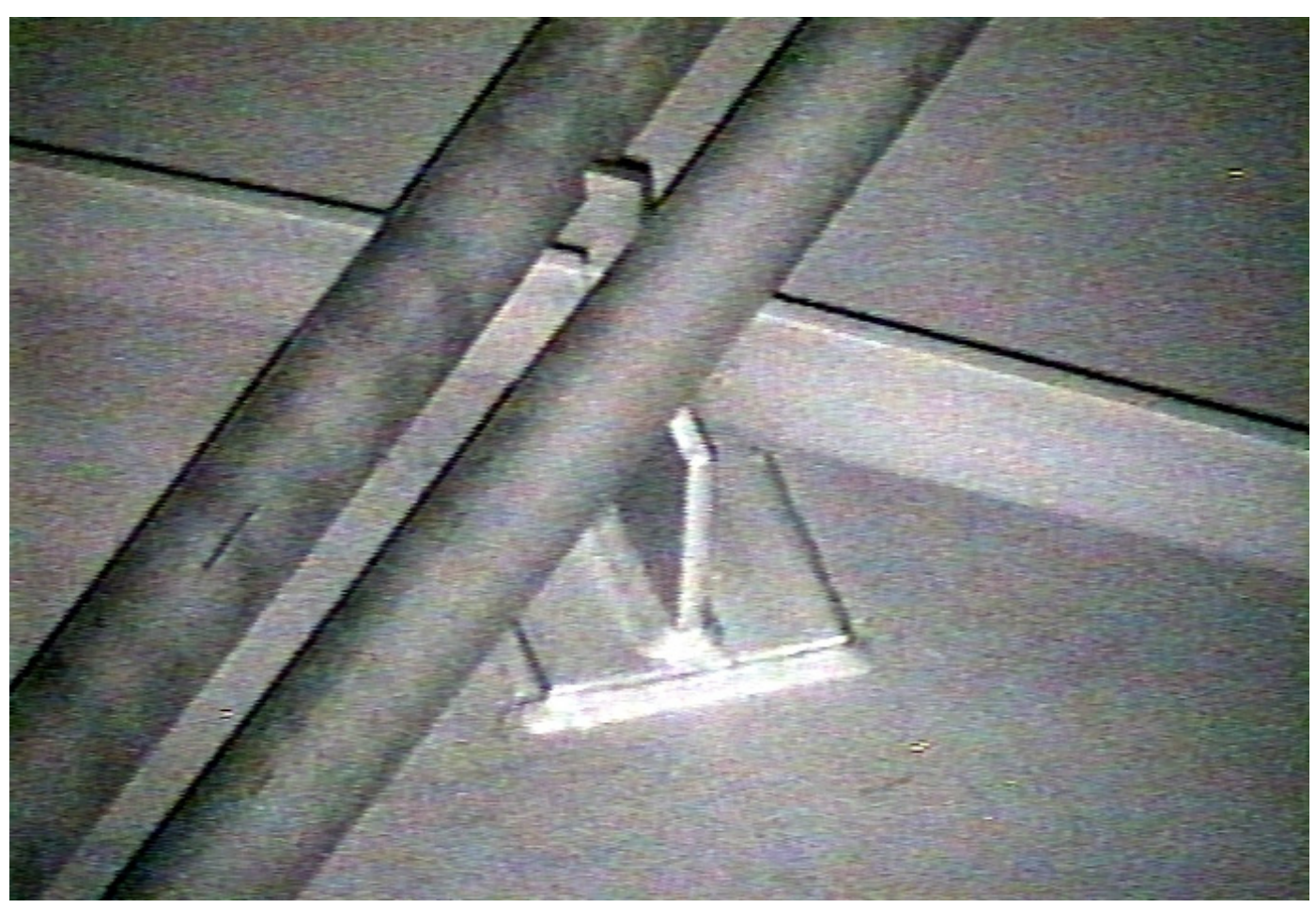

Figure D-13. WM-185 cooling coils and support.

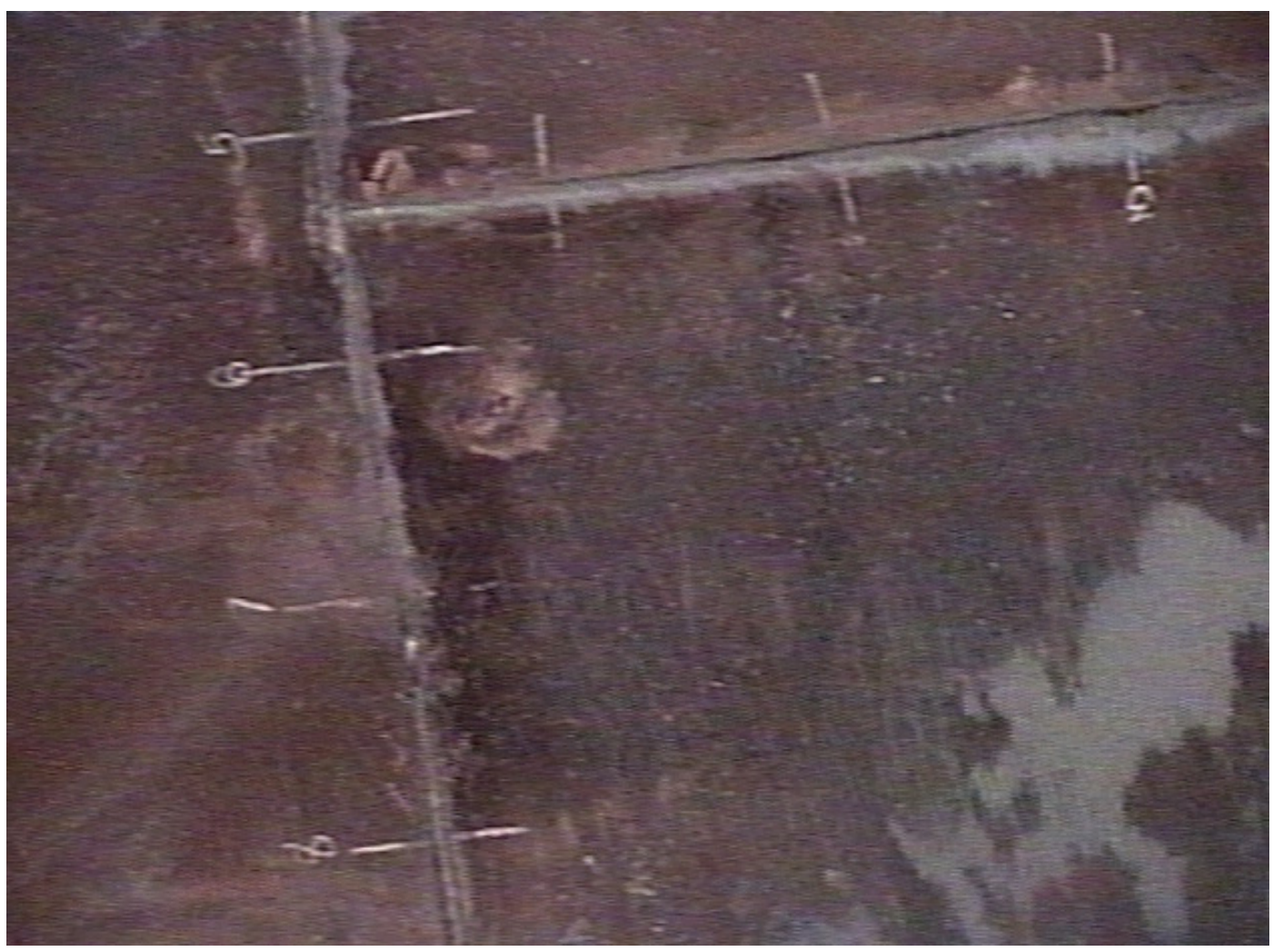

Figure D-14. WM-186 bottom welds, including fabrication positioning marks. 


\section{D6. REFERENCES}

1. Idaho National Engineering and Environmental Laboratory, "ICPP Tank Farm HLLWT Visual Inspections," Video Tracking Number INEEL 1999-EXT-193, Bechtel BWXT Idaho, LLC, Idaho Falls, Idaho, January 12, 1994.

2. Moffitt, W. C., to Distribution, "Production Department Monthly Report for October 1986," WCM-251-86, November 7, 1986.

3. Willis, N. P., to F. S. Ward, "Liquid Waste Tank Bottom Inspection," NPW-06-87, October 5, 1987.

4. Patterson, M., Light Duty Utility Arm Deployment in Tank WM-188, INEEL/EXT-99-01302, Idaho National Engineering and Environmental Laboratory, Bechtel BWXT Idaho, LLC, Idaho Falls, Idaho, December 1999.

5. Palmer, W. B., P. A. Anderson, W. J. Dirk, M. D. Staiger, M. C. Swenson, and F. S. Ward, Status and Estimated Life of the 300,000-Gallon INTEC Tanks, INEEL/EXT-99-00743, Rev. 1, Idaho National Engineering and Environmental Laboratory, Lockheed Martin Idaho Technologies Company, Idaho Falls, Idaho, November 1999.

6. Valentine, J. H., to J. T. Case, “Contract No. DE-AC07-99ID13727-Consent to Utilize Tank WM-187 for Receipt of Flush Solutions from Tanks WM-182 and WM-183," JHV-037-02, CCN 32219, May 22, 2002.

7. Yoder, T. S., to J. W. Bryant, "General Corrosion Observations from Video Inspections of WM-182, WM-183, WM-187 and WM-188, TSY-02-02,” July 8, 2002. 
D-16 


\section{Appendix E \\ Laboratory-Scale Corrosion Testing}


E-2 


\section{Appendix E}

\section{Laboratory-Scale Corrosion Testing}

The history of laboratory-scale corrosion testing of the nominal 300,000-gal tanks at the Tank Farm Facility (TFF) is presented in this appendix.

Laboratory-scale corrosion testing of the materials used in the construction of the 300,000-gal tanks was initiated before construction commenced. The original decision to use Type 347 stainless steel for Tanks WM-180 and WM-181 was based on process development corrosion studies that were conducted at Oak Ridge National Laboratory in Oak Ridge, Tennessee. ${ }^{1}$ The results of other laboratory-scale corrosion testing are summarized in the following sections.

\section{E1. CORROSION OF TYPE 304L STAINLESS STEEL EXPOSED TO FLUORIDE-BEARING DECONTAMINATION SOLUTIONS}

Experiments were conducted with synthetic fluoride-bearing decontamination solutions of the type produced during decontamination of the Waste Calcining Facility (CPP-633) to determine the corrosion rates that could be expected on the tube bundle during evaporation in the original Process Equipment Waste Evaporator (WL-113). ${ }^{2}$ Although these tests were performed for the WL-113 evaporator, these types of solutions were routinely stored in the TFF; however, at a much lower temperature. During the tests, corrosion coupons were placed in solutions containing 1- $M$ nitrate and $0.01-M$ aluminum with varying concentrations of fluoride and zirconium. The maximum corrosion rate of 4.0 mils per month was observed in a solution containing $0.27-M$ fluoride and $0.003-M$ zirconium. The tests revealed a linear relationship between the corrosion rate and the excess fluoride as defined by the free fluoride concentration:

$\mathrm{F}-(2 \mathrm{Al}+4 \mathrm{Zr})$

where

$\mathrm{F}=$ fluoride concentration in moles/liter

$\mathrm{Al}=$ aluminum concentration in moles/liter

$\mathrm{Zr}=$ zirconium concentration in moles/liter.

The experimenter concluded that sufficient zirconium or aluminum or both should be present to maintain the excess fluoride below $0.07 \mathrm{M}$ to control the corrosion rate to below 1.0 mils per month. ${ }^{2}$

\section{E2. CORROSION COUPON TESTING OF TYPE 304L STAINLESS STEEL EXPOSED TO PILOT PLANT CALCINER SOLUTIONS}

During corrosion testing conducted in 1977, corrosion rates were calculated based on Type 304L stainless steel coupons placed in the off-gas system of a 30-cm (12-in.) pilot plant calciner during a 45-hour calciner pilot plant test. ${ }^{3}$ The calciner test was designed to prove the calcinability of Tank WM-183 waste, which was a composite of aluminum fuel reprocessing raffinate, electrolytic waste, decontamination solutions, and evaporator bottoms. This information is useful because the rest of the 300,000-gal tanks also are constructed from Type 304L stainless steel, and calciner scrub solutions are 
stored in these tanks. The evaluation revealed light general corrosion with a maximum corrosion rate of 0.13 mils per month in the quench tower of the off-gas system.

\section{E3. CORROSION TESTING OF TYPE 304L STAINLESS STEEL EXPOSED TO ZIRCONIUM SOLUTIONS CONTAINING CHLORIDE}

Corrosion testing was performed on simulated scrub solutions that would be produced as a result of calcination of zirconium-containing intermediate level waste. ${ }^{4}$ The tests were performed with solutions containing different concentrations of chloride. The tests performed indicated that exposure to chlorides in excess of $0.1 \mathrm{M}$ results in pitting and preferential attack of the heat-affected zones in weld areas. These tests were performed at $85^{\circ} \mathrm{C}$, which is much higher than the normal temperature of solutions stored in the TFF.

\section{E4. CORROSION TESTING OF TYPE 304L STAINLESS STEEL EXPOSED TO SIMULATED FLUORINEL HIGH-LEVEL WASTE SOLUTIONS.}

Corrosion testing was performed to study the effects of fluorinel high-level waste (HLW) solutions on the 300,000-gal tanks. ${ }^{5}$ The test results showed increasing corrosion rates with increasing levels of free fluoride and increasing temperature. However, the overall corrosion rates were low with no evidence of localized corrosion attack. The maximum corrosion rate of 0.698 mils per year was observed in a solution containing $0.060-M$ free fluoride at $35^{\circ} \mathrm{C}$. Based on the testing, the nominal flowsheet condition of $0.045-M$ free fluoride and a $30^{\circ} \mathrm{C}\left(86^{\circ} \mathrm{F}\right)$ storage temperature were concluded to appear satisfactory for storage of high-level fluorinel waste and that the temperature and free fluoride concentration in the tanks must be closely monitored to prevent excess corrosion. ${ }^{5}$

\section{E5. EVALUATION OF TANK SOLUTION INTERFACE CORROSION}

Corrosion at the liquid surface of the 300,000-gal tanks was evaluated in $1988 .{ }^{6}$ Indications of corrosion at the liquid-vapor space interface would be apparent on coupon holder cables. During withdrawal of corrosion coupons, the cables are rinsed and wiped down with a cloth to reduce contamination in the riser. No reference was made to visible localized attack of the stainless steel cables based on this corrosion evaluation or in any of the applicable reports. ${ }^{7}$ The tank cables were constructed of Type 410 or Type 304 stainless steel wire rope that has many crevices that would show increased attack if interface corrosion were a problem.

\section{E6. CONCENTRATED WASTE CORROSION TESTING}

During 2001, testing was performed to determine the impact of adding concentrated SBW to Tanks WM-188 and WM-189. ${ }^{8}$ The waste is a result of concentrating SBW from other tanks in the evaporator tank system (ETS) to reduce the total storage volume. Modeling of the ETS bottoms has shown that the waste will contain about 3- $M$ acid, about 6.5- $M$ nitrate, about 1,200-ppm chloride, up to 4,000-ppm fluoride, and other noncorrosive components. The objective of the testing was to quantify corrosion rates expected from the concentrated waste.

The test matrix involved the use of Type 304L stainless steel coupons that were placed in the liquid and vapor space above six different solutions (which are listed in Table E-1) at two temperatures, $25^{\circ} \mathrm{C}$ $\left(77^{\circ} \mathrm{F}\right)$ and $35^{\circ} \mathrm{C}\left(95^{\circ} \mathrm{F}\right)$. Four test methods were performed: crevice tests, immersion tests, U-bend tests, and slow-strain rate tests. All testing and decontamination of the coupons prior to weighing was performed in accordance with American Society for Testing and Materials (ASTM) standards. ${ }^{8}$ 
Table E-1. Composition of concentrated waste corrosion test solutions. ${ }^{8}$

\begin{tabular}{lcccccc}
\hline \multicolumn{1}{c}{ Component } & Solution 1 & Solution 2 & Solution 3 & Solution 4 & Solution 5 & Solution 6 \\
\hline Acid $\left(\mathrm{H}^{+}\right)(M)$ & 3.0 & 3.0 & 3.0 & 3.0 & 3.0 & 3.0 \\
Aluminum $\left(\mathrm{Al}^{3+}\right)(M)$ & 0.5 & 0.5 & 0.5 & 0.5 & 0.5 & 0.5 \\
Chloride $\left(\mathrm{Cl}^{-}\right)(\mathrm{ppm})$ & 5000 & 5000 & 3000 & 3000 & 1000 & 1000 \\
Fluoride $\left(\mathrm{Fl}^{-}\right)(M)$ & 0.12 & 0.12 & 0.12 & 0.12 & 0.12 & 0.12 \\
Iron $\left(\mathrm{Fe}^{2+}\right)(M)$ & 0.015 & 0.03 & 0.015 & 0.03 & 0.015 & 0.03 \\
Sulfate $\left(\mathrm{SO}_{4}^{2-}\right)(M)$ & 0.062 & 0.06 & 0.03 & 0.03 & 0.03 & 0.03 \\
Nitrate $\left(\mathrm{NO}_{3}^{-}\right)(M)$ & 4.2 & 8.07 & 4.27 & 8.3 & 4.3 & 8.3 \\
\hline
\end{tabular}

The initial test consisted of three crevice, three immersion, and three U-bend coupons that were placed in test solutions at $35^{\circ} \mathrm{C}\left(95^{\circ} \mathrm{F}\right)$ (see Solutions 1 and 2 in Table E-1). The average corrosion rates that were measured for the immersion and crevice coupons, which were suspended in the liquid, are listed in Table E-2. Microscopic examination of the coupons indicated no localized corrosion. During the first of two phases of testing, the U-bend coupons were placed so that the bend was in the solution and the ends of the coupons were above the solution. Although the bends revealed no indications of cracking and only minor general attack, the ends of the coupons showed extensive attack from solution number 2 . However, it should be noted that in the tanks the end grain is not exposed. Figures E-1 and E-2 show the U-bend coupons from the first phase of testing. ${ }^{8}$

Resulting from the corrosion attack during the first phase of testing, the test matrix was expanded to a second phase evaluating six solutions and two temperatures. ${ }^{8}$ During the second phase of testing, the crevice test coupons were suspended in the vapor space above the test solution. Table E-3 contains a list of the average corrosion rates of the crevice coupons during the second phase of testing. Visual observations of the coupons revealed significant general corrosion where droplets condensed on the surface of the coupons that were suspended above the 8- $M$ nitrate solutions. None of the coupons suspended above the 4- $M$ nitrate solutions showed this corrosion. The difference in the degree of corrosion attack that occurred on the coupons can be seen in Figure E-3.

The following conclusions were drawn from this testing:

- The corrosion rates of the coupons suspended in the liquid were sufficiently low to be considered acceptable

- $\quad$ The corrosion that occurred on the coupons that were suspended above the 8- $M$ nitrate solutions was excessive. The most likely explanation for this to occur is that the high-nitrate concentration caused the chloride to become volatile. The nitrate, however, did not volatilize. The chloride then condensed on the coupon where it attacked the metal that could not be passivated by the nitrate. Because excessive corrosion did not occur with the 4- $M$ nitrate solutions, it appears that this phenomenon is concentration dependent. ${ }^{8}$

During 2002, a laboratory study was performed to determine whether corrosion could be occurring at nitrate levels below $8 M$. Corrosion coupons were exposed to simulated waste solutions with 5- $M, 6-M$, or 7-M nitrate concentrations, and 1,000 or 3,000 ppm chlorides. All of the coupons used in immersion tests were found to have corrosion rates low enough to be considered acceptable. However, the vapor phase of the waste solutions at the 6- and 7- $M$ nitrate concentrations with 3,000-ppm chloride appeared to be too corrosive. The corrosion was not evident in the vapor phase at chloride levels of $1,000 \mathrm{ppm}{ }^{9}$ 
During 2003, an additional laboratory study was performed to more closely model the liquid stored in WM-188 and WM-189. Analysis of these tanks indicated concentrations to be about 6.5 molar nitrate and from $750 \mathrm{ppm}$ to $1230 \mathrm{ppm}$ chloride. Since these operational concentrations are very close to those which generated corrosion in previous laboratory tests, the testing was expanded to identify the chloride concentrations at which vapor space corrosion is initiated. The results of these tests indicate there is a cause for concern about vapor phase corrosion if the Tank Farm waste exceeds a concentration of $6 M$ nitrate and 1500 ppm chloride. ${ }^{10}$

Current and expected Tank Farm waste concentrations are below these values, so vapor phase corrosion is not expected to be initiated in the tanks.

Table E-2. Average corrosion rates of coupons during first phase of 2001 corrosion testing at $35^{\circ} \mathrm{C}^{46}$

\begin{tabular}{ccc}
\hline & $\begin{array}{c}\text { Average Corrosion Rate } \\
\text { for Crevice Coupons } \\
\text { (mils/year) }\end{array}$ & $\begin{array}{c}\text { Average Corrosion Rates } \\
\text { for Immersion Coupons } \\
\text { (mils/year) }\end{array}$ \\
\hline 1 & 0.0097 & 0.0031 \\
2 & 0.0133 & 0.0075 \\
\hline
\end{tabular}
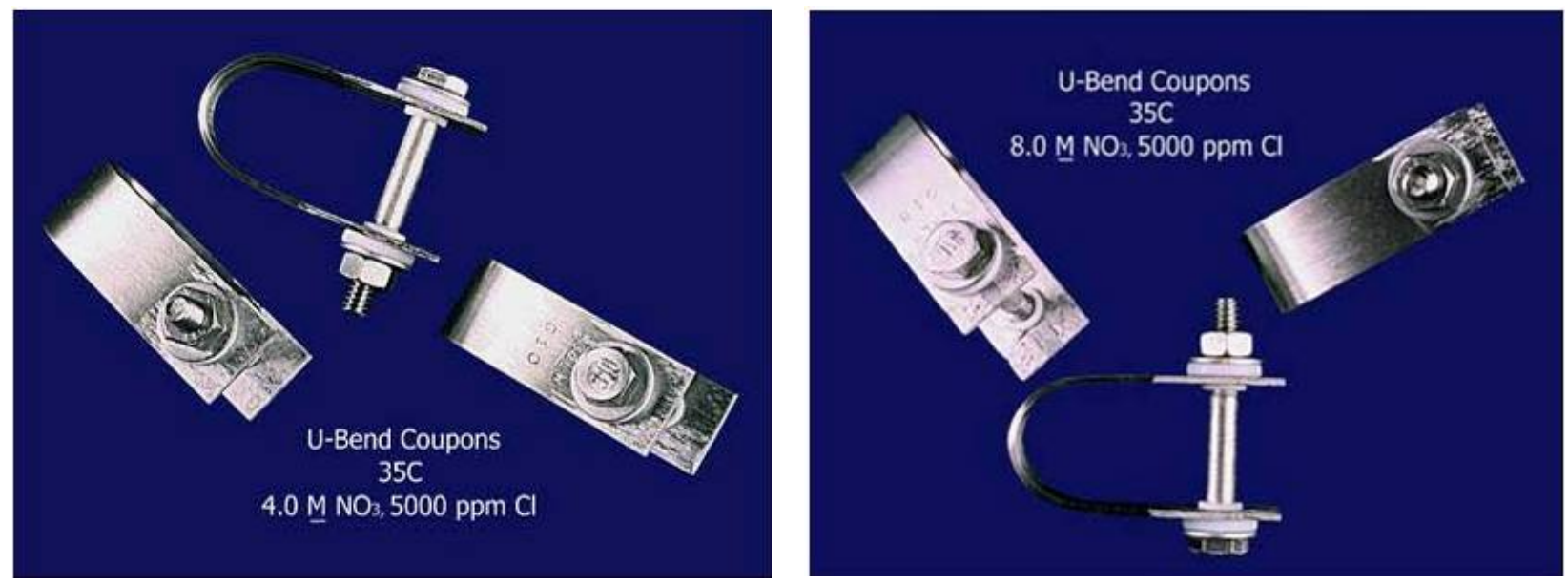

Figure E-1. U-bend coupons from first phase of 2001 corrosion testing (PD010403-2-15 and PD010403-3-15). ${ }^{8}$ 


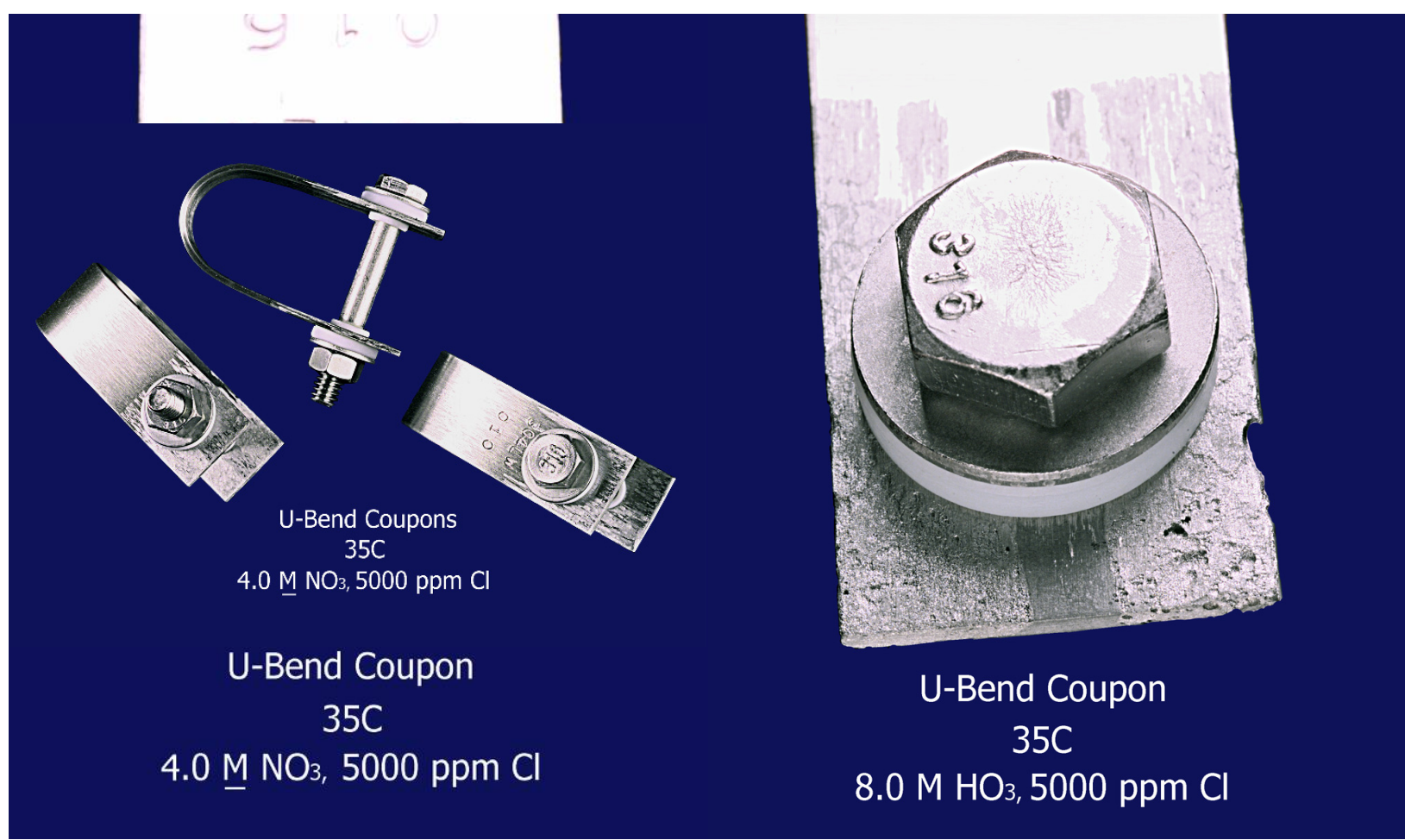

Figure E-2. Close-up of U-bend coupons from first phase of 2001 corrosion testing (PD010403-4-22 and PD010403-4-25). ${ }^{8}$

Table E-3. Average corrosion rates of crevice coupons during second phase of testing. ${ }^{8}$

\begin{tabular}{ccc}
\hline & $\begin{array}{c}\text { Average Corrosion Rate } \\
\text { for Coupons at } 35^{\circ} \mathrm{C} \\
\text { (mils/year) }\end{array}$ & $\begin{array}{c}\text { Average Corrosion Rates } \\
\text { for Coupons at } 25^{\circ} \mathrm{C} \\
\text { (mils/year) }\end{array}$ \\
\hline 1 & 0.0035 & 0.0029 \\
2 & 0.0257 & 0.0326 \\
3 & 0.0038 & 0.0053 \\
4 & 0.0353 & 0.0285 \\
5 & 0.0038 & 0.0021 \\
6 & 0.0147 & 0.0067 \\
\hline
\end{tabular}



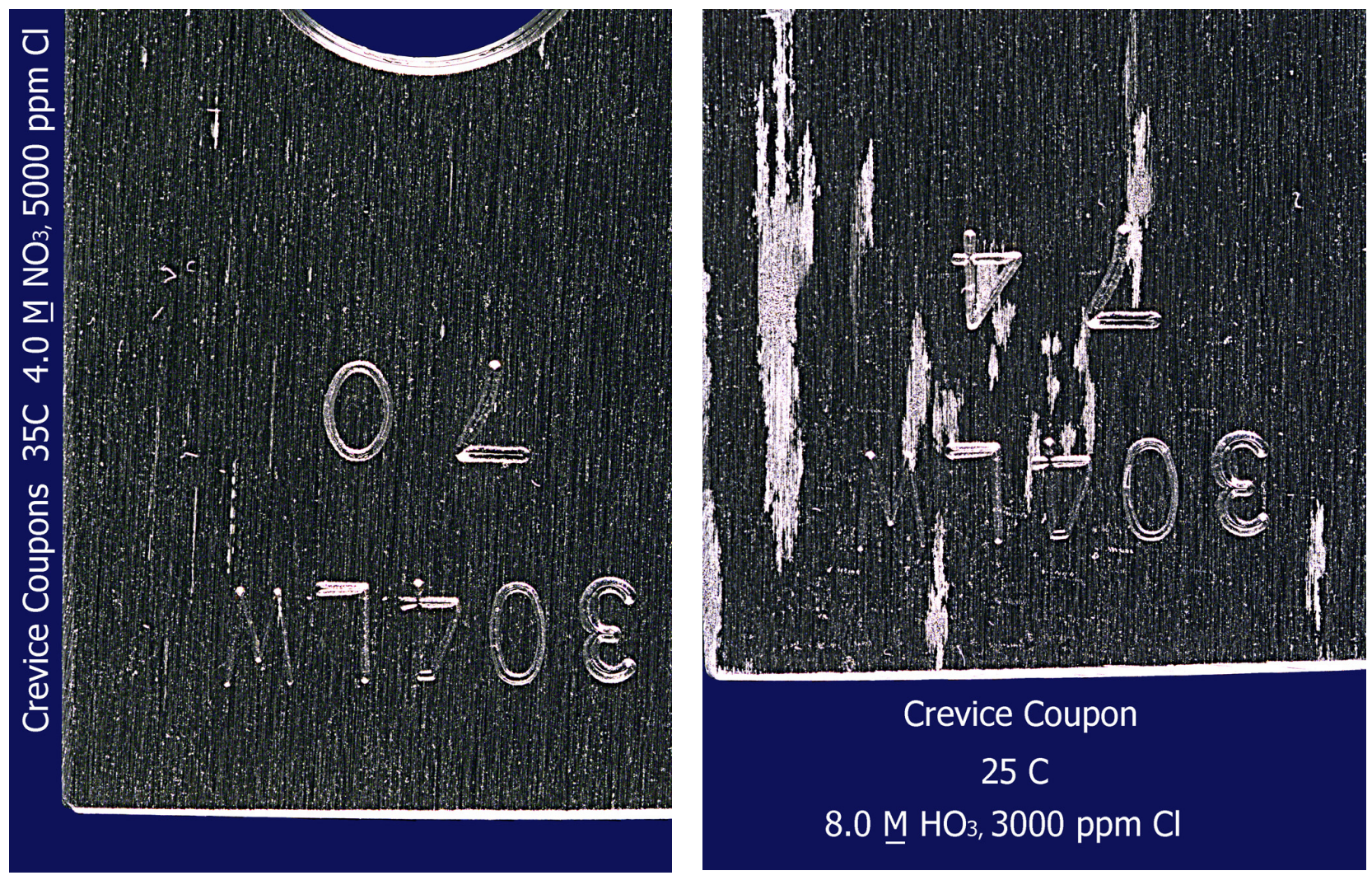

Figure E-3. Crevice coupons suspended above solution noted (PD010403-3-20 and PD010403-4-21).

\section{E7. ELECTROCHEMICAL NOISE TESTING}

One newly developed method of monitoring corrosion is the electrochemical noise (ECN) probe. Low-frequency fluctuations in measured current and voltage associated with corrosion can be measured with ECN. An electrochemical noise probe system is under development and, if successful, could provide an early warning system for identification of increases in pit initiation. In their most basic form, ECN-based corrosion monitoring systems measure and record these fluctuations over time from electrodes immersed in the environment of interest. The resulting ECN signals have characteristic patterns for different corrosion mechanisms.

In applications involving carbon steel tanks and caustic waste at the Hanford Site near Richland, Washington, and the Savannah River Site (the latter in conjunction with Raman spectroscopy) in Aiken, South Carolina, ECN monitoring techniques have shown considerable promise for detecting pit initiation. Initial indications are that the technique can be successfully adapted to the stainless steel tanks and caustic waste at Oak Ridge. However, application to the stainless steel tanks and acidic waste at the INEEL may represent a greater challenge because of the different corrosion processes that could apply. A test program to assess the feasibility of applying ECN at the INEEL was conducted in FY-2002. For this test, a system including both the corrosion monitor and appropriate software was procured. A number of experiments were conducted at various temperatures in solutions with a waste chemistry simulating Tank WM-189 and representative of the other tanks. The tests showed that initial signals indicate significant, active corrosion. Passivation occurs in all cases after the initial period, and is attributed to the dissolution of 
inclusions from the surface. The ECN signals appear to be sensitive to the corrosion characteristics of the Type 304L material. However, temperature of the solution did not appear to have a strong influence on the data. In addition, the stability of weld areas versus the base material does not appear to be an issue influencing corrosion. All indications point to stability of the Type 304L samples in the solution simulating Tank WM-189 liquid waste after the initial period. ${ }^{11}$ 


\section{E8. REFERENCES}

1. Hoffman, T. L., Corrosion Evaluation of Stainless Steels Exposed in ICPP High-Level Radioactive Waste Tanks, IDO-14600, Atomic Energy Commission, Idaho Operations, Idaho Falls, Idaho, December 1962.

2. Hoffman, T. L., to D. W. Rhodes, "Corrosion of Type 304L Stainless Steel in Fluoride-Bearing Decontamination Solutions,” Hof-7-68, May 15, 1968.

3. Dirk, W. J., to A. P. Hoskins, "Corrosion Coupon Testing of Type 304L SS in the 12 Calciner-Run \#61 WM-183 Waste Solutions,” Dirk-11-77, April 21, 1977.

4. Dirk, W. J., to A. P. Hoskins, "Corrosion Testing of Type 304L Stainless Steel in Zr-ILW Solutions Containing High Levels of Chloride," Dirk-1-78, January 5, 1978.

5. Mizia, R. L., to J. D. Christian, "Corrosion Test Results of Simulated Fluorinel HLLW Solutions Exposed to 304L Stainless Steel," REM-24-84, October 24, 1984.

6. Dirk, W. J., to F. S. Ward, "Evaluation of Tank Farm Vessel Solution Interface Corrosion," Dirk-33-88, September 6, 1988.

7. Zimmerman, C. A., Corrosion Evaluation of ICPP High-Level Liquid Waste Storage Tanks, WINCO-1064, Idaho National Engineering Laboratory, Westinghouse Idaho Nuclear Company, Idaho Falls, Idaho, April 1989.

8. Yoder, T. S., to J. M. White, "Results of WM-187, WM-188, and WM-189 Concentrated Waste Corrosion Testing," TSY-05-01, September 25, 2001.

9. Yoder, T. S., to J. M. White, "Results of Secondary WM-187, WM-188, and WM-189 Concentrated Waste Corrosion Testing," TSY-01-02, April 22, 2002.

10. Yoder, T. S., to J. M. White, "FY2003 INTEC Tank Farm Concentrated Waste Corrosion Testing," TSY-03-03, September 25, 2003.

11. Lister, T., Electrochemical Noise Testing Report \#2, Experiments Covering August-November 2002, Idaho National Engineering and Environmental Laboratory, Bechtel BWXT Idaho, LLC, Idaho Falls, Idaho, November 21, 2002. 


\section{Appendix F \\ Quantification of Ancillary Equipment Degradation}


F-2 


\section{Appendix F}

\section{Quantification of Ancillary Equipment Degradation from Corrosion}

Quantification of the degradation of ancillary equipment from corrosion at the Tank Farm Facility (TFF) is summarized in this appendix.

A specific corrosion monitoring program that addresses ancillary equipment does not exist for the $\mathrm{TFF}^{1}$ The reason is that metal losses by corrosion in the ancillary equipment are substantially lower than in the waste tanks and corrosion monitoring of the waste tanks will bound conservatively the corrosion occurring in the ancillary equipment. The reason for the lower metal losses in the ancillary equipment is that the equipment is in contact with the waste only a fraction of the time that waste is in the tanks. Specifically, once waste enters a tank it is in contact with the tank (at least the tank bottom) 100\% of the time until the tank is closed. In the case of the individual 300,000-gal tanks, this will be from 45 to 60 years. However, the most often used section of waste transfer line in the TFF has been exposed to waste solutions for the equivalent time of only 2 months or less than one hundredth of the service time of the tanks.

Corrosion concerns could arise if the ancillary equipment were constructed of materials different than the tanks, had substantially thinner walls than the tanks, or were subjected to higher temperatures than solutions in the tanks. Investigation showed that none of these is a significant concern. The ancillary equipment is made of the same materials as the tanks (Type 304L or 347 stainless steel). The bulk of the ancillary equipment consists of transfer lines constructed of pipe, most of which is 3 -in. Schedule 40 pipe. The wall thickness of this pipe is $0.216 \mathrm{in}$., which is very much like the 0.25 -in. thickness of the upper walls of the waste tanks.

With the use of steam jets to transfer waste to and from the tanks, the solutions transferred through the ancillary piping could be elevated in temperature briefly. Based on available data, a jet dilution of approximately 4 to $5 \%$ appears to be average for a TFF waste transfer. Such a dilution will result in a temperature increase of approximately 24 to $31^{\circ} \mathrm{C}\left(75\right.$ to $\left.88^{\circ} \mathrm{F}\right)$ in the waste solution and process piping above the temperature of the waste in the tank. Because the SBW solutions now in the 300,000-gal tanks are low in radioactivity, they are not cooled. These solutions have come to equilibrium with ambient conditions and range in temperature from 10 to $20^{\circ} \mathrm{C}$. Historically, the temperature of some tank waste has been slightly higher, but significant waste heating from decay will not occur in the future because the current waste is much less radioactive than previous waste. The modest short-term temperature gain caused by use of the steam jets will not cause a significant increase in corrosion. The WM-187, -188 , -189 , and -190 tanks also are equipped with airlifts to transfer waste. Use of the airlifts does not result in a temperature increase because air is used instead of steam.

During the many upgrades of the waste transfer piping associated with the TFF, no corrosion failures of the stainless steel piping have been identified. In 1974, a leak was discovered in a transfer line resulting from a hole that was inadvertently drilled in the pipe during original construction in 1955 and 1956. To determine the cause of failure, a section of pipe containing the hole was cut out for inspection. This inspection indicated that the pipe, in general, had suffered very little corrosion damage during its 18 years of intermittent service and the failure was strictly a result of mechanical damage. ${ }^{2}$ Evidence of another leak was identified in 1975. In this instance, acidic solution got past a partially open valve and contacted some carbon steel piping, which leaked and radioactive solution was released to the soil in the TFF. No other carbon steel to stainless steel piping connections now exist in the TFF. ${ }^{3}$ 
The Waste Calcining Facility (CPP-633) quench system also provides evidence that corrosion and erosion should not be a problem. The Waste Calcining Facility was designed and built at the same time, in the late 1950s, by the same architect engineer and construction crews, using the same methods and technology as several of the 300,000-gal tanks. The quench system at the Waste Calcining Facility was made of the same material as the TFF transfer piping. The quench system solution was similar in composition to TFF solution. However, it was often significantly higher than TFF solution in the concentration of chlorides and undissolved solids. The chloride concentration made the solution more corrosive than TFF solutions and the undissolved solids concentration increased the erosion potential of the solution. The Waste Calcining Facility processed 4 million gal of waste. At a rate of 80 gal per hour, that volume represents 50 thousand hours (nearly 6 years) of continuous operation. The total does not include startup time, nonradioactive operation, and decontamination operations. The normal operating temperature of the quench tank was approximately $65^{\circ} \mathrm{C}$. The quench solution conditions are much more severe from a corrosion standpoint (with higher temperature, a higher chloride concentration, and longer exposure) than are conditions in the tank transfer lines. Yet, the quench solution piping never failed.

During investigation of the 1974 leak in the TFF, valve and flange gaskets made of Teflon were identified with indications of radiation damage. All of the valves in both Valve Boxes A-3A and A-3B were removed, decontaminated, and reconditioned, with new bellows and bonnets, and replacement of Teflon gaskets with blue African asbestos. ${ }^{2}$ Subsequently, many other valves in the TFF have been repaired or replaced. All of the TFF valves are located in valve boxes, which are provided with leak detection or drains to locations that are provided with leak detection. Therefore, although leaking valves are a possibility because of wear and fatigue, the possibility has been addressed through the facility design and operating procedures.

The TFF underground piping is cathodically protected. As a result, cathodic degradation is not considered to have had an adverse impact on the TFF.

\section{F1. SUMMARY OF QUANTIFICATION OF ANCILLARY EQUIPMENT DEGRADATION}

In summary, no leaks resulting from corrosion are associated with the ancillary equipment, nor are failures caused by corrosion of the equipment anticipated. The construction material of the ancillary equipment (for example, transfer piping, valves, and steam jets) is the same as the 300,000-gal tanks, but some of the equipment is subject to slightly higher temperatures during solution transfers while the steam jets are being used than during tank storage. However, the amount of time the ancillary equipment has actually been exposed to the higher temperatures is very small, approximately 2 months, compared to the continuous exposure of the tanks to process solutions, which is approximately 40 years. Therefore, the corrosion coupons in the tanks should be representative conservatively of the uniform corrosion in the ancillary equipment. Design of the transfer systems takes into account the possibility of leaks, and repairs to valves are made when necessary. 


\section{F2. REFERENCES}

1. Palmer, W. B., P. A. Anderson, W. J. Dirk, M. D. Staiger, M. C. Swenson, and F. S. Ward, Status and Estimated Life of the 300,000-Gallon INTEC Tanks, INEEL/EXT-99-00743, Rev. 1, Idaho National Engineering and Environmental Laboratory, Lockheed Martin Idaho Technologies Company, Idaho Falls, Idaho, November 1999.

2. Rigstad, N. J., ICPP Tank Farm Contaminated Soil Incident of October 1, 1974, Idaho National Engineering Laboratory, Allied Chemical Corporation, Idaho Falls, Idaho, March 1, 1975.

3. Commander, R. E., Revised Investigation Report ICPP Tank Farm Contaminated Soil Incident of September 18, 1975, Idaho National Engineering Laboratory, Allied Chemical Corporation, Idaho Falls, Idaho. 
F-6 


\section{Appendix G \\ Quantification of Tank Vault Degradation}


G-2 


\section{Appendix G}

\section{Quantification of Tank Vault Degradation}

\section{G1. CHEMICAL ATTACK OF CONCRETE}

Quantification of the degradation of the 300,000-gal tank vaults from corrosion at the Tank Farm Facility (TFF) is summarized in this appendix.

Aggressive chemical attack was identified as a degradation mechanism for the 300,000-gal tank vaults. For the most part, the vaults have contained only water resulting from external groundwater infiltration. However, incidents have been recorded of solutions stored in the tanks being inadvertently siphoned into the vaults. ${ }^{1}$ In 1962, two such incidents occurred: 31,700 gal of acidic radioactive waste were siphoned into the Tank WM-187 vault, where the waste remained for 35 hours before the vault contents were emptied, and subsequently 33,500 gal of acidic radioactive waste were siphoned into the Tank WM-185 vault and remained there for 21 1/4 hours before the vault contents were emptied. ${ }^{1}$ These are the worse-case incidents for exposure of the tank vaults to chemical attack. The investigation report for these incidents indicated that material balance calculations were performed, but the calculations could not with adequate precision establish conclusively that no leakage occurred from the vaults. As a monitoring precaution, three holes within $15 \mathrm{~m}(50 \mathrm{ft})$ of the vaults were drilled to a depth of $15 \mathrm{~m}(50 \mathrm{ft})$. Samples from these holes revealed no anomalous moisture, and radiation levels were not significantly higher than background. ${ }^{1}$

Several experiments have been conducted to determine the approximate rate of attack on the concrete vault using simulated waste solution. Following the 1962 siphoning incidents, a penetration rate of $0.008 \mathrm{~cm} /$ hour $(0.0031 \mathrm{in}$./hour) was determined over 6 hours of experimentation using $0.7-M$ nitric acid. ${ }^{1}$ In 1989, additional experiments were performed when questions concerning compatibility of the concrete were raised based on RCRA requirements. ${ }^{2}$ The concrete penetration rate of highly acidic fluorinel was determined in the experiments to be $0.0089 \mathrm{~cm} /$ hour $(0.0035 \mathrm{in}$./hour $)$ over 55 hours using 3.1- $\mathrm{M} \mathrm{H}^{+}$. This rate translates to penetration of a 6-in.-thick concrete wall, for the pillar-and-panel vaults, occurring in 71 days from a leak into an intact vault. For the pillar-and-panel vaults used for Tanks WM-182, WM-183, WM-184, WM-185, and WM-186, breeching of the grout around the panels was estimated to occur in 35 to 71 days. ${ }^{3}$ Further tests performed in $1990^{4}$ resulted in an even lower calculated concrete penetration rate of $0.012 \pm 0.007 \mathrm{in}$./day $(0.0005 \mathrm{in} . /$ hour or $0.0013 \mathrm{~cm} /$ hour $)$ over 200 hours using 2.1 to $4.3-M \mathrm{H}^{+}$.

Exposure of the Tank WM-187 vault for 35 hours at a rate of $0.0089 \mathrm{~cm} /$ hour would result in a calculated worse-case concrete penetration of $0.3 \mathrm{~cm}(0.12 \mathrm{in}$.). This is a very small penetration compared the wall thickness; therefore, the vaults exposed to tank waste likely remain in good shape.

\section{G2. CHEMICAL ATTACK OF REINFORCING STEEL}

If acidic solutions were to contact the reinforcing steel of the tank concrete vaults, the steel would be expected initially to corrode fairly rapidly, with considerable slowing over time. One test indicated that the penetration rate would be $1 \mathrm{~cm} /$ day $(0.4$ in/day $) .{ }^{5}$ Construction drawings show the reinforcing steel to be $5 \mathrm{~cm}$ ( $2 \mathrm{in}$.) from the concrete surface for the poured vaults, and $2.5 \mathrm{~cm}$ (1 in.) for the panels of the pillar-and-panel vaults. The worse-case concrete penetration calculated above is considerably less than $5 \mathrm{~cm}$ ( $2 \mathrm{in}$.). Therefore, the reinforcing steel of the vaults likely has not been exposed to chemical attack and is in good shape. 


\section{G3. REFERENCES}

1. Latchum, J. W., et al, "Report of the Investigating Committee CPP Waste Tank WM-187 Leakage of March 17, 1962,” La-53-62A, April 17, 1962.

2. Newby, B. J., to V. C. Maio, "Penetration Rate of Fluorinel Waste Into Concrete," Nby-11-89, March 30, 1989.

3. Newby, B. J., to L. F. Ermold, "Grout Penetration Rate of Fluorinel Waste Based on Concrete Studies," June 1, 1990.

4. Brewer, K. N., to G. R. Franz, “Concrete Encased Pipe Compatibility Study,” KNB-09-90, October 18, 1990.

5. Brewer, K. N., to C. V. Park, "FPR Concrete Encased Pipe Compatibility Study," KNB-08-90, October 5, 1990. 